FLÁVIO ANDRÉ DA CUNHA MUNHOZ

EFEITO DE ADIÇÕES ATIVAS NA MITIGAÇÃO DAS REAÇÕES ÁLCALI-SÍLICA E ÁLCALI-SILICATO 
FLÁVIO ANDRÉ DA CUNHA MUNHOZ

\section{EFEITO DE ADIÇÕES ATIVAS NA MITIGAÇÃO DAS REAÇÕES ÁLCALI-SÍLICA E ÁLCALI-SILICATO}

Dissertação apresentada à Escola Politécnica da Universidade de São Paulo para obtenção do título de Mestre em Engenharia

Área de Concentração:

Engenharia de Construção Civil e Urbana

Orientador:

Prof ${ }^{\mathrm{a}}$. Dr ${ }^{\mathrm{a}}$. Maria Alba Cincotto 
Este exemplar foi revisado e alterado em relação à versão original, sob responsabilidade única do autor e com a anuência de seu orientador.

São Paulo, 03 de setembro de 2007.

Assinatura do autor

Assinatura do orientador

FICHA CATALOGRÁFICA

Munhoz, Flávio André da Cunha

Efeito de adições ativas na mitigação das reações álcali-

sílica e álcali-silicato / F.A. da C. Munhoz. -- ed.rev. -- São Paulo, 2007.

$166 \mathrm{p}$.

Dissertação (Mestrado) - Escola Politécnica da Universidade de São Paulo. Departamento de Engenharia de Construção Civil.

1.Estruturas de concreto 2.Reação álcali-agregado (Prevencão) I.Universidade de São Paulo. Escola Politécnica. Departamento de Engenharia de Construção Civil II.t. 


\section{AGRADECIMENTOS}

À Associação Brasileira de Cimento Portland (ABCP) por permitir as condições necessárias à realização desse trabalho.

À Prof ${ }^{a}$ Dra Maria Alba Cincotto pela orientação, acompanhamento e sugestões que contribuíram para o resultado final.

Ao Profo Dr. Yushiro Kihara que tem me orientado profissionalmente e pessoalmente nos últimos 25 anos e é claro também no mestrado.

Ao Geól. Arnaldo Forti Battagin pelo incentivo e direcionamento profissional.

Ao Geól. Marcelo Pecchio pelas discussões sobre reação álcali-agregado e ajuda nas análises microscópicas que contribuíram para enriquecer o trabalho.

Ao Geól. Vagner Maringolo pela revisão e ponderações sobre o texto.

Ao Eng. Rubens Curti e a Tecnola Celina Yokoyama por terem me substituído em algumas ocasiões no meu trabalho diário.

À Eng. Elza Nakakura pela leitura e sugestões para o texto.

Ao Eng. Carlos Eduardo Regattieri pelo incentivo para a realização do mestrado.

Ao Geól. José Maria do Instituto Geológico/SMA pela brilhante descrição petrográfia dos agregados.

À equipe técnica do Laboratório de Cimento pela realização dos ensaios acelerados em barras de argamassa em especial Cláudio, Edgar, Maria Alice e Miguel.

À equipe do Laboratório de Química pela realização dos ensaios químicos descritos no trabalho e de outros para fundamentar algumas observações, em especial Francisco Planelles, Sérgio, Aguinaldo.

À Patrícia e ao Douglas do Laboratório de Mineralogia pela realização dos ensaios mineralógicos.

A todos os funcionários da $\mathrm{ABCP}$, que direta ou indiretamente ajudaram na realização desse trabalho.

E as minhas famílias, porque tenho o privilégio de ter mais de uma, em especial a Paula e ao Cesar, que acompanharam o mestrado de longe é claro, pela ausência do marido e pai. E a minha mãe, que também contribuiu com o que toda mãe tem de melhor, que é a dedicação aos filhos incondicionalmente. 


\section{RESUMO}

A reação álcali-agregado é uma manifestação patológica diretamente ligada à seleção dos materiais (cimento, agregados miúdo e graúdo, água e aditivos) que pode comprometer a durabilidade das estruturas de concreto, uma vez que a interação desses materiais e as condições ambientais é que vão conferir ao concreto determinadas propriedades ligadas à sua vida útil. A reação entre os hidróxidos alcalinos solubilizados na fase líquida dos poros dos concretos e alguns agregados reativos é lenta e resulta em um gel que, ao se acumular em vazios do concreto e na interface pasta-agregado, na presença de água, se expande, exercendo pressão interna no concreto. Ao exceder a resistência à tração do concreto, a pressão interna pode promover fissurações. A reação álcali-agregado requer a atuação conjunta de água, agregado reativo e álcalis. Sua prevenção pode ser feita a partir da eliminação de um dos fatores, ou seja, a partir do emprego de agregados inertes ou de cimentos com baixos teores de álcalis ou isolamento da umidade. $\mathrm{Na}$ impossibilidade de eliminar um dos fatores, medidas preventivas devem ser tomadas para o emprego de agregados reativos em obras de construção civil. Entre essas, destacam-se a utilização de cimentos com baixos teores de álcalis ou a de cimentos com adições ativas mitigadoras da reação álcali-agregado: escória de alto-forno, cinza volante, metacaulim e sílica ativa, que foi o objeto de pesquisa do presente trabalho. No programa experimental foram analisados dois tipos de agregado potencialmente reativos com os hidróxidos alcalinos: basalto e milonito granítico. O primeiro, proveniente de rocha ígnea, tem como constituintes deletérios vidro, clorofeíta, calcedônia (sílica criptocristalina), que dará origem à reação do tipo álcali-sílica. $\mathrm{O}$ agregado milonito granítico provém de rocha metamórfica, tem como constituintes deletérios quartzo microgranular, quartzo recristalizado, quartzo com extinção ondulante e quartzo e feldspato deformados, que dará origem ao tipo de reação álcali-silicato. Com o objetivo de avaliar a eficiência de adições ativas em mitigar as reações, os agregados foram combinados com 16 cimentos com adições ativas. Escória de alto-forno foi adicionada a 15\%, 30\%, 45\% e 60\% e cinza volante, a $10 \%, 15 \%, 25 \%$ e $35 \%$, teores normalmente encontrados nos cimentos brasileiros. Metacaulim foi adicionada a 5\%,10\%, 15\% e 20\%, e sílica ativa, a 5\%, 10\% e $15 \%$, teores representativos da faixa normalmente adicionada diretamente a concretos. Todos os materiais utilizados foram caracterizados química, física e mineralogicamente, incluindo a análise petrográfica dos agregados. As barras de argamassa foram analisadas ao MEV, microscópio óptico de luz transmitida, realizaram-se ensaios de porosimetria por intrusão de mercúrio e análises térmicas para quantificar a teor de portlandita residual, e determinou-se o teor de álcalis dentro das barras após a realização dos ensaios para verificar a migração de íons de sódio. Os resultados indicam que a eficiência das adições ativas varia de acordo com a composição química e mineralógica das adições, da proporção desse material no cimento, e do grau de reatividade do agregado.

Palavras-chave: Reação álcali-agregado. Cimento Portland. Escória de alto-forno. Cinza Volante. Metacaulim. Sílica Ativa. Basalto. Milonito. Agregado. 


\section{ABSTRACT}

The alkali-aggregate reaction is a pathologic manifestation that can induce the premature distress and loss in serviceability of concrete structures affected. It is directly associated to the selection of materials (cement, coarse and fine aggregates, water and additives), as the interaction between these materials and environmental condition will grant the concrete some of the properties related to its service life. The slow reaction between alkali hydroxides soluble in the liquid phase within concrete pores and reactive aggregates gives rise to a gel that piles up within concrete voids and the aggregate-paste interface. In presence of water, the gel expands and exerts internal pressure in the concrete. When the internal pressure exceeds the tensile strength, cracking may come up as result. The alkali-aggregate reaction requires the action of water, reactive aggregate and alkalis altogether. Prevention can be carried out by eliminating one of these factors, i.e. employing either inert aggregates or lowalkali cements, or keeping the concrete away from moisture. Otherwise, preventive measures must be taken when reactive aggregates are used in civil construction works, such as the use of low-alkali cements or composite cements bearing alkaliaggregate-reaction mitigating admixtures: blast-furnace slag, fly ash, metakaolin and silica fume, which are the object of the present research. The experimental work included the analysis of two potentially reactive aggregates to alkali hydroxides: basalt and granite milonite. The igneous basalt carries deleterious constituents such as glass, chloropheite (cryptocrystalline silica), that will give rise to the alkali-silica type reaction while the metamorphic granite milonite carries micro granular, recrystallized, undulate-extinction-bearing quartz and deformed feldspar grains, that give rise to alkali-silicate type reaction. Aiming at evaluating how efficient in mitigating these reactions the active admixtures are, these aggregates were mixed with 16 composite cements. The contents of admixtures followed those usually found in Brazilian industrial cements for blast-furnace slag $(15 \%, 30 \%, 45 \%, 60 \%)$ and fly ash $(10 \%, 15 \%, 25 \%, 35 \%)$, and those generally added directly to concrete for metakaolin $(5 \%, 10 \%, 15 \%, 20 \%)$ and silica fume $(5 \%, 10 \%, 15 \%)$. All materials were characterized for their chemical composition, physical properties and mineralogy. Petrography was carried out on the aggregates. The mortar bars were analyzed at the scanning electronic and transmitted-light optical microscopes. Mercury-intrusion porosimetry and thermal analyses were carried out to quantify residual portlandite. The alkali content within the bars was determined in order to verify migration of $\mathrm{Na}^{+}$ions. The results show that the efficiency of active admixtures varies according to their chemical and mineralogical composition and proportioning in cement, and to the aggregate reactivity.

Keywords: Alkali-aggregate reaction. Portland cement. Blast-furnace slag. Fly ash. Metakaolin. Silica fume. Basalt. Milonite. 


\section{LISTA DE TABELAS}

Tabela 1 - Estruturas hidráulicas de concreto no Brasil com reação álcaliagregado 9

Tabela 2 - Agregados e fases mineralógicas potencialmente reativas (Hasparyk, 1999). 14

Tabela 3 - Teor de álcalis $\left(\mathrm{kg} / \mathrm{m}^{3} \mathrm{Na}_{2} \mathrm{O}_{e}\right)$ fornecido pelo cimento ao concreto em função da dosagem de cimento $\left(\mathrm{kg} / \mathrm{m}^{3}\right)$ e do teor de álcalis do cimento $\left(\% \mathrm{Na}_{2} \mathrm{O}_{\mathrm{e}}\right)$ 24

Tabela 4 - Prescrições químicas dos cimentos brasileiros. 50

Tabela 5 - Prescrições físico-mecânicas dos cimentos brasileiros. 50

Tabela 6 - Síntese dos principais trabalhos sobre minimização da expansão devida à reação álcali-agregado, utilizando sais de lítio 59

Tabela 7 - Granulometria requerida do agregado para ensaio acelerado 64

Tabela 8 - Resultados percentuais da composição química do cimento e das adições ativas 69

Tabela 9 - Características físicas e desempenho dos aglomerantes. 71

Tabela 10 - Composição química dos agregados 73

Tabela 11 - Síntese das principais características petrográficas da amostra de milonito granítico 74

Tabela 12 - Síntese das principais características petrográficas da amostra de basalto. 75

Tabela 13 - Determinação do índice de atividade pozolânica com cal dos agregados 76

Tabela 14 - Caracterização química do cimento CP V-ARI 126

Tabela 15 - Teores de álcalis solúveis e totais do cimento CP V-ARI 127

Tabela 16 - Caracterização físico-mecânica do cimento CP V-ARI 127

Tabela 17 - Análise química da escória de alto-forno 128 
Tabela 18 - Caracterização física da escória de alto-forno 129

Tabela 19 - Compostos mineralógicos cristalizados identificados na escória de alto-forno

Tabela 20 - Grau de vitrificação e natureza da escória de alto-forno.

Tabela 21 - Composição da argamassa para determinação da atividade hidráulica da escória

Tabela 22 - Atividade hidráulica da escória de alto-forno.

Tabela 23 - Composição química da cinza volante 132

Tabela 24 - Caracterização física da cinza volante 133

Tabela 25 - Compostos mineralógicos cristalizados identificados na cinza volante.

Tabela 26 - Composição da argamassa para o ensaio de atividade pozolânica com cal

Tabela 27 - Índice de atividade pozolânica com cal da cinza volante 135

Tabela 28 - Composição das argamassas para o ensaio de atividade pozolânica com cimento.

Tabela 29 - Resistência à compressão, índice de atividade pozolânica e água requerida da cinza volante

Tabela 30 - Composição química do metacaulim.

Tabela 31 - Caracterização física do metacaulim.

Tabela 32 - Compostos mineralógicos cristalizados identificados no metacaulim . 138

Tabela 33 - Caracterização por análises termodiferencial e termogravimétrica do metacaulim

Tabela 34 - Composição da argamassa para o ensaio de atividade pozolânica com cal

Tabela 35 - Índice de atividade pozolânica com cal do metacaulim. 140

Tabela 36 - Composição das argamassas para o ensaio de atividade pozolânica com cimento. 
Tabela 37 - Resistência à compressão, índice de atividade pozolânica e água requerida do metacaulim

Tabela 38 - Composição química da sílica ativa

Tabela 39 - Análise química da amostra de milonito granítico

Tabela 40 - Compostos mineralógicos cristalizados identificados na amostra de milonito granítico

Tabela 41 - Caracterização física do agregado milonito granítico após moagem .. 147

Tabela 42 - Composição da argamassa para o ensaio de atividade pozolânica com cal

Tabela 43 - Índice de atividade pozolânica com cal do milonito granítico

Tabela 44 - Análise química da amostra de basalto

Tabela 45 - Compostos mineralógicos cristalizados identificados na amostra de basalto.

Tabela 46 - Caracterização física do agregado basalto após moagem 152

Tabela 47 - Composição da argamassa para o ensaio de atividade pozolânica com cal.

Tabela 48 - Índice de atividade pozolânica com cal do basalto 152

Tabela 49 - Variação dimensional das barras de argamassa em solução alcalina Milonito granítico + Cimento com Escória

Tabela 50 - Variação dimensional das barras de argamassa Milonito granítico + Cimento com Cinza Volante.

Tabela 51 - Variação dimensional das barras de argamassa em solução alcalina Milonito granítico + Cimento com Metacaulim 155

Tabela 52 - Variação dimensional das barras de argamassa em solução alcalina Milonito granítico + Cimento com Sílica Ativa 156

Tabela 53 - Variação dimensional das barras de argamassa em solução alcalina Basalto + Cimento com Escória 157

Tabela 54 - Variação dimensional das barras de argamassa em solução alcalina Basalto + Cimento com Cinza Volante 158 
Tabela 55 - Variação dimensional das barras de argamassa em solução alcalina Basalto + Cimento com Metacaulim 159

Tabela 56 - Variação dimensional das barras de argamassa em solução alcalina Basalto + Cimento com Sílica Ativa 160

Tabela 57 - Resistências mecânicas das barras de argamassa 161

Tabela 58 - Análise termodiferencial - identificação das reações 163

Tabela 59 - Faixas de temperatura para calcular as perdas de massa da análise termogravimétrica 163

Tabela 60 - Perda de massa e teor de hidróxido de cálcio das barras de argamassa com agregado milonito granítico 164

Tabela 61 - Teores de álcalis solúveis das barras de argamassa 165

Tabela 62 - Principais parâmetros obtidos no ensaio de porosimetria por intrusão de mercúrio para as barras de argamassa ensaiadas 


\section{LISTA DE FIGURAS}

Figura 1 - Liberação de álcalis dos agregados em solução supersaturada de $\mathrm{Ca}(\mathrm{OH})_{2}$ e em água destilada a $80^{\circ} \mathrm{C}$ aos 28 dias em diversas frações (Duyou et al., 2006)

Figura 2 - Relação entre a concentração de íons $\mathrm{OH}^{-}$em equilíbrio na solução dos poros e teor de álcalis $\left(\% \mathrm{Na}_{2} \mathrm{O}_{\mathrm{e}}\right)$ no cimento. Ensaios realizados em pastas e argamassas com relação água:cimento 0,50 (Diamond, 1989).

Figura 3- Classificação do comportamento da reação em função da relação entre os álcalis disponíveis e o consumo de cimento no concreto (Oberholster, Van Aardt \& Brandt, 1983 apud Hasparyk, 1999)

Figura 4 - Efeito da umidade relativa na expansão do concreto devido à reação álcali-agregado (Poole, 1992).

Figura 5 - Arranjo atômico de minerais do grupo da sílica com estrutura ordenada e bem cristalizados, e com estrutura desordenada e mal cristalizados (Collins, 2007)

Figura 6 - Grão de agregado em contato com a solução dos poros com fase reativa devido à estrutura cristalina desordenada (Collins, 2007)

Figura 7 - A superfície do agregado é atacada pelos íons $\mathrm{OH}^{-}$que rompe a ligação Si-O-Si para formar grupos de silanol (Collins, 2007)

Figura 8 - Grupos de silanol ( $\mathrm{Si}-\mathrm{OH}$ ) são rompidos pelos íons $\mathrm{OH}^{-}$em íons de $\mathrm{SiO}^{-}$, sobre a superfície do agregado (Collins, 2007)

Figura 9 - Os íons de SiO liberados são atraídos pelos cátions alcalinos da solução dos poros, formando gel de silicato alcalino em torno do agregado. Si-OH $+\mathrm{Na}^{+}+\mathrm{OH}^{-} \rightarrow \mathrm{Si}-\mathrm{O}-\mathrm{Na}+\mathrm{H}_{2} \mathrm{O}$ (Collins, 2007)

Figura 10 - O gel alcalino, ao absorver água, expande, exercendo pressão osmótica sobre a pasta de cimento ou agregado (Collins, 2007)

Figura 11 - Ilustração do processo de fabricação do clínquer 
Figura 12 - Tipos de cimentos produzidos no Brasil e teores de adição permitidos por norma

Figura 13 - Teor médio de adição por tipo de cimento em 2003

Figura 14 - Resumo da composição dos aglomerantes empregados

Figura 15 - Resumo dos ensaios de caracterização dos materiais selecionados

Figura 16 - Resumo dos ensaios de determinação da expansão em barras de argamassa pelos métodos acelerado

Figura 17 - Resumo dos ensaios de caracterização das barras de argamassa

Figura 18 - Evolução da variação dimensional com o tempo de cura em solução alcalina das amostras de agregado

Figura 19 - Variação dimensional - Milonito granítico + Cimento com escória

Figura 20 - Variação dimensional - Milonito granítico + Cimento com cinza volante

Figura 21 - Variação dimensional - Milonito granítico + Cimento com metacaulim

Figura 22 - Variação dimensional - Milonito granítico + Cimento com sílica ativa

Figura 23 - Variação dimensional - Basalto + Cimento com escória

Figura 24 - Variação dimensional - Basalto + Cimento com cinza volante

Figura 25 - Variação dimensional - Basalto + Cimento com metacaulim

Figura 26 - Variação dimensional - Basalto + Cimento com sílica ativa

Figura 27 - Resistência à tração na flexão das barras de argamassa submetidas aos ensaios acelerados a $80^{\circ} \mathrm{C}$, em solução $1 \mathrm{~N}$ de $\mathrm{NaOH}$ durante 28 dias.

Figura 28 - Resistência à compressão das barras de argamassa submetidas aos ensaios acelerados a $80^{\circ} \mathrm{C}$, em solução $1 \mathrm{~N}$ de $\mathrm{NaOH}$ durante 28 dias

Figura 29 -Teor de hidróxido de cálcio das barras de argamassa com agregado milonito granítico 
Figura 30 - Teores de $\mathrm{K}_{2} \mathrm{O}$ (entre $0,03 \%$ e $0,18 \%$ ) e de $\mathrm{Na}_{2} \mathrm{O}$ (entre $0,60 \%$ e $1,07 \%)$ solúveis das barras de argamassa com agregado milonito granítico

Figura 31 - Volume de intrusão de mercúrio por grama de amostra $(\mathrm{ml} / \mathrm{g})$ em função da quantidade de poros de um determinado diâmetro

Figura 32 - Espectro de EDS mostrando composição química típica de produtos de RAA.

Figura 33 - Espectro de EDS do gel que se espalhou sobre a argamassa.

Figura 34 - Espectro da análise da composição do produto da RAA observado entre os cristais de quartzo.

Figura 35 - Espectro de EDS do produto de RAA fibroso formado a partir do sódio.

Figura 36 - Espectro de EDS mostrando que os produtos de RAA foram formados com a participação de sódio e cálcio

Figura 37 - Espectro de EDS confirmando se tratar de cristal de feldspato

Figura 38 - Espectro de EDS representativo da composição química do produto da reação álcali-sílica encontrado sobre a superfície dos grãos de basalto.

Figura 39 - Espectro de EDS mostrado composição similar aos produtos da reação álcali-silicato do agregado milonito granítico.

Figura 40 - llustra a redução da expansão do agregado milonito granítico quando combinado com cimentos com adição de escória, cinza volante, metacaulim e sílica ativa

Figura 41 - Ilustra a redução da expansão do agregado basalto quando combinado com cimentos com adição de escória, cinza volante, metacaulim e sílica ativa

Figura 42 - llustra a eficiência dos cimentos com adição de escória de altoforno, cinza volante, metacaulim e sílica ativa em reduzir a expansão dos agregados milonito granítico e basalto. 
Figura 43 - llustra a redução da expansão em porcentagem do agregado milonito granítico quando combinado com cimentos com adição de escória de alto-forno, cinza volante, metacaulim e sílica ativa.

Figura 44 - llustra a redução da expansão em porcentagem do agregado basalto quando combinado com cimentos com adição de escória de alto-forno, cinza volante, metacaulim e sílica ativa.

Figura 45 - Mostra a redução da expansão dos agregados milonito granítico (A) e basalto $(\mathrm{B})$ à medida que a relação $\mathrm{CaO} / \mathrm{SiO}_{2}$ dos cimentos experimentais diminui.

Figura 46 - Redução da expansão em função do teor de hidróxido de cálcio 110

Figura 47 - Gráfico de difratometria de raios $X$ da escória de alto-forno 130

Figura 48 - Gráfico de difratometria de raios X da cinza volante

Figura 49 - Gráfico de difratometria de raios X do metacaulim 138

Figura 50 - Gráfico das análises térmica e termogravimétrica do metacaulim 139

Figura 51 - Gráfico de difratometria de raios $X$ da sílica ativa 143

Figura 52 - Gráfico de difratometria de raios $\mathrm{X}$ do milonito granítico 


\section{LISTA DE FOTOS}

Foto 1 - Bloco de fundação com padrão de fissuração típico de RAA (Pecchio et al., 2006)

Foto 2 - Cristais de quartzo deformado (QD) que, associado a quartzo recristalizado $(\mathrm{QR})$, conferem ao agregado caráter reativo. $(\mathrm{F}=$ feldspato). Observado ao microscópio de luz transmitida. Ampliação 100x (Acervo ABCP).

Foto 3 - Cristais de quartzo microcristalino (QM) que, associado a quartzo recristalizado $(\mathrm{QR})$, conferem ao agregado caráter reativo. ( $\mathrm{F}=$ feldspato). Observado ao microscópio de luz transmitida. Ampliação 100x (Acervo ABCP).

Foto 4 - Fase criptocristalina de calcedônia que confere ao material caráter reativo. Observada ao microscópio de luz transmitida. Ampliação 100x (FAA, 2004)

Foto 5 - Bloco de fundação com quadro fissuratório típico de RAA (Acervo $A B C P)$.

Foto 6 - Agregados graúdos com RAA na interface agregado/matriz de cimento (Pecchio et al., 2006).

Foto 7 - Aspecto do concreto no qual se observa a formação de borda de reação ao redor do agregado graúdo. Microscópio estereoscópico. Ampliação 9x (Acervo ABCP).

Foto 8 - Aspecto do concreto no qual se observa a deposição de gel (seta) no contorno do agregado graúdo (A). ( $P$ = Pasta) Microscópio de luz transmitida. Ampliação 100x (Acervo ABCP).

Foto 9 - Detalhe de concreto no qual se observa poro parcialmente preenchido por material esbranquiçado (gel). Microscópio estereoscópico. Ampliação 6x (Acervo ABCP).

Foto 10 - Gel gretado proveniente da reação álcali-silicato. O gretamento indicando fissuração é resultado do preparo da amostra e efeito da 
incidência do feixe eletrônico. Microscópio eletrônico de varredura. Ampliação 350x (Acervo ABCP).

Foto 11 - Cristais idiomórficos de alita $(A)$ e arredondados de belita $(B)$ e fase intersticial (E). Microscopia de luz refletida. Ampliação 400x (Acervo $\mathrm{ABCP}$ ).

Foto 12 - Fase intersticial cristalizada com nítida diferenciação dos cristais de $\mathrm{C}_{3} \mathrm{~A}(\mathrm{C})$ e $\mathrm{C}_{4} \mathrm{AF}(\mathrm{F})$. ( $\mathrm{A}=$ alita). Microscopia de luz refletida. Ampliação 400x (Acervo ABCP).

Foto 13 - Cristais prismáticos de gipsita artificial. Microscopia de luz transmitida. Ampliação 100x (Acervo ABCP).

Foto 14 - Grãos irregulares de hemidrato obtidos a partir da desidratação da gipstita de origem natural. Microscopia de luz transmitida. Ampliação 100x (Acervo ABCP).

Foto 15 - Grãos de fíler calcário ao microscópio óptico de luz transmitida.

Ampliação 80x (Acervo ABCP). 44

Foto 16 - Grãos de escória essencialmente vítreos, com formas irregulares. Fração 38 - 45 $\mu \mathrm{m}$. Microscopia de luz transmitida. Ampliação 80x (Acervo ABCP). 46

Foto 17 - Micrografia de grãos esféricos de cinza volante obtida ao microscópio eletrônico de varredura. (Plerosferas: caracteriza-se por elevada área específica favorecida por moagem, a qual libera as partículas menores). Ampliação 3500x (Acervo ABCP).

Foto 18 - Aspecto de detalhe da textura da rocha na qual se observam cristais de feldspato $(F)$ triturados envolvidos por matriz de quartzo microgranular $(Q)$ e mica. Microscópio de luz transmitida. Ampliação $25 x$

Foto 19 - Aspecto de detalhe da textura da rocha na qual se observam fenocristais de plagioclásio $(P)$ e matriz fina composta de plagioclásio, opacos (magnetita) e clorofeíta (C). V=masa intersticial composta por opacos e vidro vulcânico. Microscópio de luz transmitida. Ampliação 25x. 
Foto 20 - Aspecto geral da barra de argamassa, em que se observam poros preenchidos com gel esbranquiçado e agregado com borda de reação. Microscópio estereoscópico. Ampliação 10x.

Foto 21 - Poro preenchido com gel esbranquiçado, com formação de anel no contorno do poro. Microscópio estereoscópico Ampliação 20x.

Foto 22 - Detalhe de poro preenchido com gel. MEV ampliação 350x 96

Foto 23 - Poro preenchido com gel transparente e gelatinoso, que se espalhou sobre a argamassa após a quebra da barras. Microscópio estereoscópico. Ampliação 20x 96

Foto 24 - Poro preenchido com gel transparente e gelatinoso e gel esbranquiçado no fundo do poro. Microscópio estereoscópico. Ampliação 15x 96

Foto 25 - Aspecto do gel espalhado sobre a argamassa. Apresenta aspecto maciço e com leve gretamento. MEV ampliação 750x.

Foto 26 - Argamassa com cimento sem adição. Grão de quartzo desagregado com espátula de aço $(A)$ e poro preenchido com gel esbranquiçado (B). Microscópio estereoscópico. Ampliação 15x. 97

Foto 27 - Argamassa moldada com cimento com 35\% de cinza volante. Grão de quartzo intacto após ser raspado intensamente com espátula de aço enquanto a argamassa, mais frágil, desagregou. Microscópio estereoscópico. Ampliação 20x.

Foto 28 - Grão do agregado milonito granítico no qual se observam cristais de quartzo separados, provavelmente em decorrência da RAA.

Microscópio de luz transmitida. Ampliação 25x. 98

Foto 29 - Grão do agregado milonito granítico com cristais de quartzo "separados" e interligado a poro preenchido por gel. Microscópio de luz transmitida. Ampliação 25x.

Foto 30 - Aspecto geral de grão do agregado milonito granítico constituído por cristais de quartzo separados por material intersticial. MEV ampliação 1000x 
Foto 31 - Detalhe dos cristais de quartzo envolvidos por produto de reação álcali-agregado. MEV ampliação 3500x.

Foto 32 - Poro preenchido por produtos de RAA com aspecto acicular característicos da participação do sódio na reação. MEV ampliação $1500 x$

Foto 33 - Cristal de quartzo recoberto por produtos de RAA com aspecto acicular. MEV apliação 3500x. 100

Foto 34 - Cristal de feldspato totalmente corroído provavelmente devido a RAA. MEV ampliação 1500x.

Foto 35 - Vista geral da barra de argamassa mostrando poros vazios e gel com aspecto leitoso sobre o agregado basalto. Microscópio estereoscópico. Ampliação 6x.

Foto 36 - Detalhe de agregado com gel com aspecto leitoso sobre a superfície do agregado basalto. Microscópio estereoscópico. Ampliação 30x.

Foto 37 - Produtos de reação álcali-sílica sobre a superfície de um cristal de feldspato. MEV ampliação 3500x. 103

Foto 38 - Gel gretado com produtos cristalizados sobre a superfície. MEV ampliação 3500x. 


\section{LISTA DE ABREVIATURAS E SIGLAS}

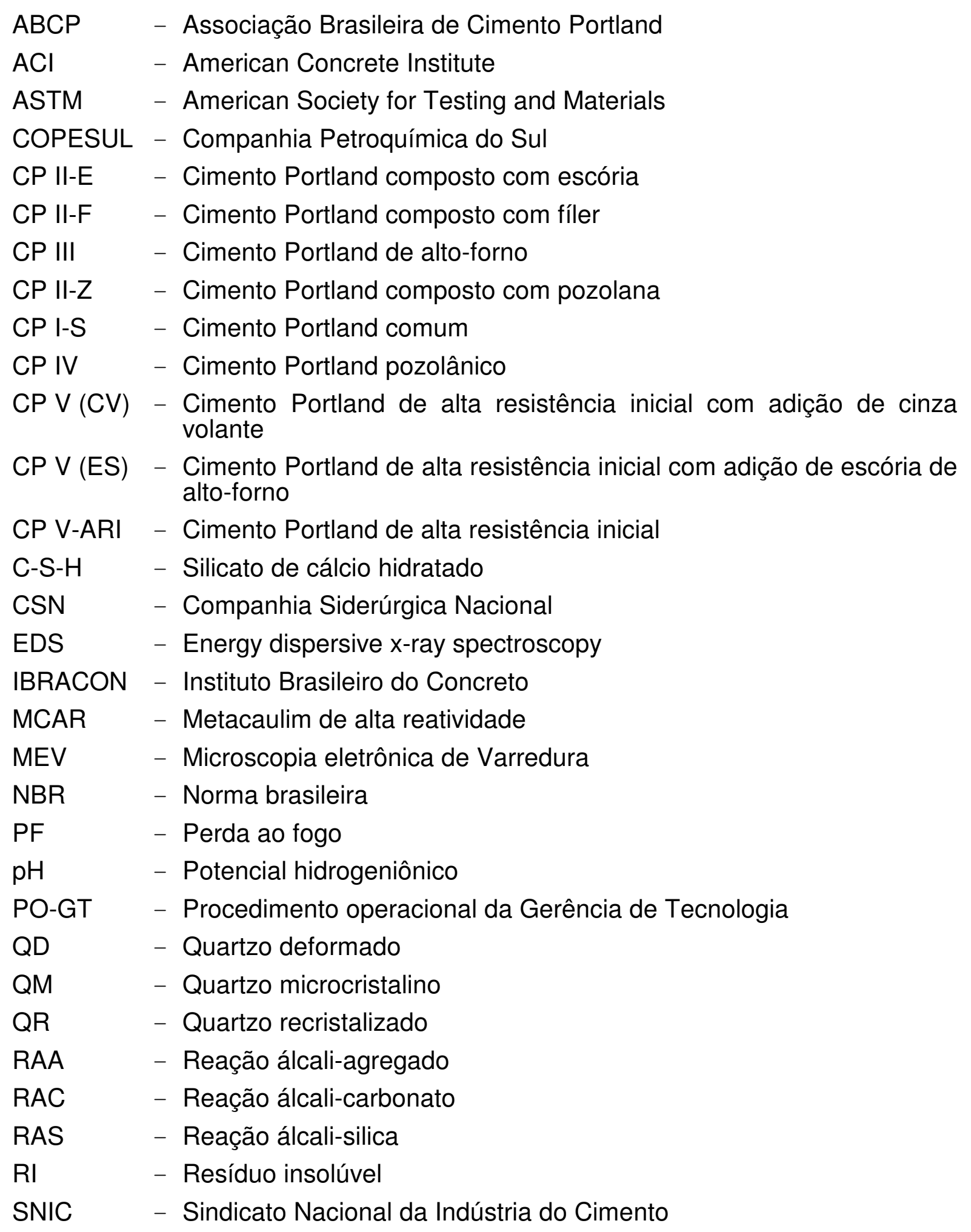




\section{NOTAÇÕES QUÍMICAS}

\begin{tabular}{|c|c|}
\hline $\mathrm{Al}_{2} \mathrm{O}_{3}$ & - Óxido de alumínio \\
\hline $\mathrm{Al}_{2} \mathrm{Si}_{2} \mathrm{O}_{5}(\mathrm{OH})_{4}$ & - Silicato de alumínio hidratado (caulinita) \\
\hline $\mathrm{C}_{2} \mathrm{~S}-\mathrm{Ca}_{2} \mathrm{SiO}_{4}$ & - Silicato dicálcico (belita) \\
\hline $\mathrm{C}_{3} \mathrm{~A}-\mathrm{Ca}_{3} \mathrm{Al}_{2} \mathrm{O}_{6}$ & - Aluminato tricálcio \\
\hline $\mathrm{C}_{3} \mathrm{~S}-\mathrm{Ca}_{3} \mathrm{SiO}_{5}$ & - Silicato tricálcico (alita) \\
\hline $\mathrm{C}_{4} \mathrm{AF}-\mathrm{Ca}_{4} \mathrm{Al}_{2} \mathrm{Fe}_{2} \mathrm{O}_{10}$ & - Ferroaluminato tetracálcico \\
\hline $\mathrm{C}_{4} \mathrm{AH}_{13}$ & - Aluminato tetracálcico hidratado \\
\hline $\mathrm{Ca}(\mathrm{OH})_{2}$ & - Hidróxido de cálcio (portlandita) \\
\hline $\mathrm{CaCO}_{3}$ & - Carbonato de cálcio (calcita) \\
\hline $\mathrm{CaO}$ & - Óxido de cálcio \\
\hline $\mathrm{CaO}$ (livre) & - Óxido de cálcio livre \\
\hline $\mathrm{CaSO}_{4}$ & - Sulfato de cálcio (anidrita) \\
\hline $\mathrm{CaSO}_{4} \cdot 1 / 2 \mathrm{H}_{2} \mathrm{O}$ & - Sulfato de cálcio hidratado (bassanita ou hemidrato) \\
\hline $\mathrm{CaSO}_{4} \cdot 2 \mathrm{H}_{2} \mathrm{O}$ & - Sulfato de cálcio di-hidratado (gipsita) \\
\hline $\mathrm{CO}_{2}$ & - Anidrido carbônico \\
\hline $\mathrm{Fe}_{2} \mathrm{O}_{3}$ & - Óxido de ferro \\
\hline $\mathrm{H}_{2} \mathrm{O}$ & - Água \\
\hline $\mathrm{K}^{+}, \mathrm{Na}^{+}, \mathrm{OH}^{-}$ & - Hidróxidos alcalinos \\
\hline $\mathrm{K}_{2} \mathrm{Ca}_{2}\left(\mathrm{SO}_{4}\right)_{3}$ & - Langbeinita cálcica \\
\hline $\mathrm{K}_{2} \mathrm{O}$ & - Óxido de potássio \\
\hline $\mathrm{K}_{2} \mathrm{SO}_{4}$ & - Sulfato de potássio (arcanita) \\
\hline $\mathrm{K}_{3} \mathrm{Na}\left(\mathrm{SO}_{4}\right)_{2}$ & - Aftitalita \\
\hline $\mathrm{Li}_{2} \mathrm{CO}_{3}$ & - Carbonato de lítio \\
\hline $\mathrm{Li}_{2} \mathrm{SO}_{4}$ & - Sulfato de lítio \\
\hline LiF & - Fluoreto de lítio \\
\hline $\mathrm{LiNO}_{2}$ & - Nitrito de lítio \\
\hline $\mathrm{LiNO}_{3}$ & - Nitrato de lítio \\
\hline $\mathrm{LiOH}$ & - Hidróxido de lítio \\
\hline $\mathrm{MgO}$ & - Óxido de magnésio \\
\hline $\mathrm{Na}_{2} \mathrm{O}$ & - Óxido de sódio \\
\hline $\mathrm{Na}_{2} \mathrm{O}_{e}$ & - Equivalente alcalino em sódio $\left(\% \mathrm{Na}_{2} \mathrm{O}+0658 \% \mathrm{~K}_{2} \mathrm{O}\right)$ \\
\hline $\mathrm{NaOH}$ & - Hidróxido de sódio \\
\hline $\mathrm{OH}^{-}$ & - Íon hidroxíla \\
\hline S & - Sulfeto \\
\hline $\mathrm{SiO}_{2}$ & - Dióxido de silício \\
\hline $\mathrm{SiO}_{2} \cdot \mathrm{n} \mathrm{H}_{2} \mathrm{O}$ & - Sílica hidratada (opala) \\
\hline $\mathrm{Si}-\mathrm{OH}$ & - Grupo silanol \\
\hline $\mathrm{SO}_{3}$ & - Anidrido sulfúrico \\
\hline
\end{tabular}




\section{SUMÁRIO}

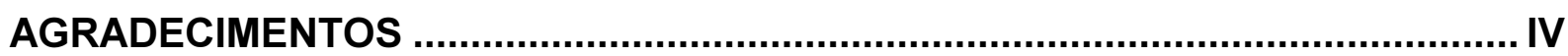

RESUMO

ABSTRACT

LISTA DE TABELAS .........................................................................................

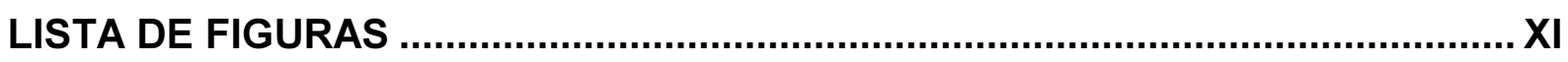

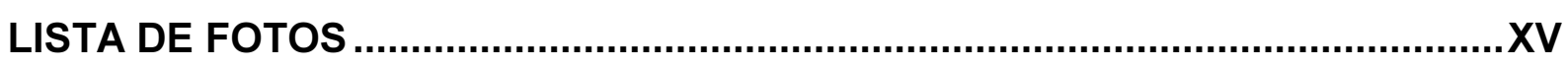

LISTA DE ABREVIATURAS E SIGLAS..........................................................X

NOTAÇÕES QUÍMICAS......................................................................................XX

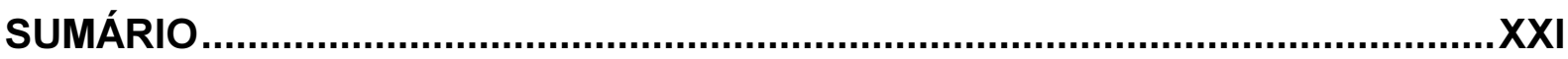

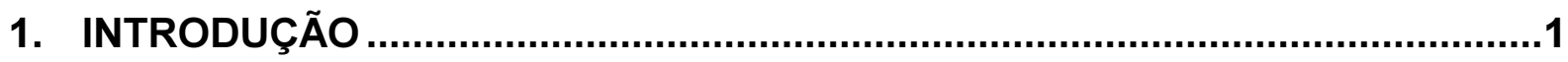

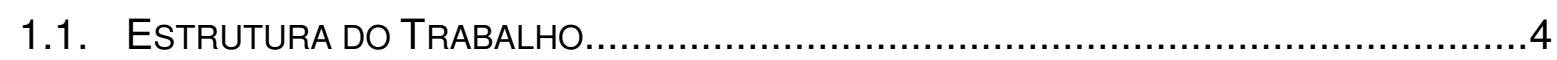

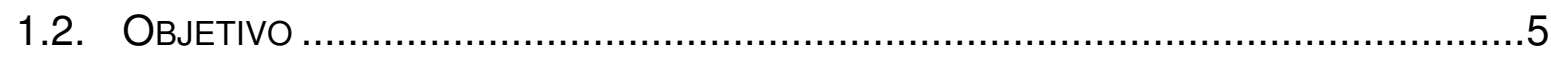

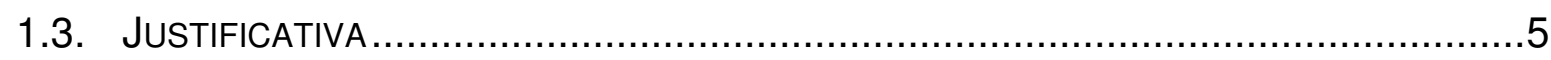

2. A REAÇÃO ÁLCALI-AGREGADO - DADOS DE LITERATURA ..........................7

2.1. A REAÇÃO ÁlCALI-AGREGADO NO CONCRETO...............................................

2.2. REAÇÃo ÁLCALI-AGREGADO NO BRASIL ......................................................

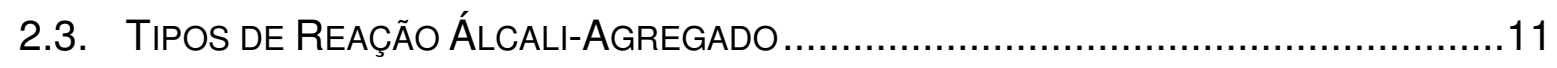

2.4. CONDIÇÕES PARA OCORRER A REAÇÃO ………………...............................12

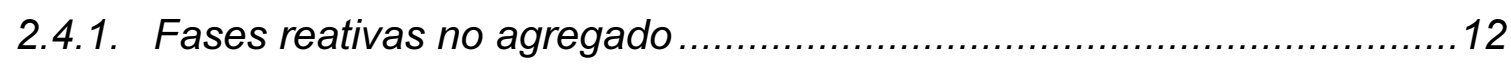

2.4.2. Concentração de hidróxidos alcalinos $\left(\mathrm{K}^{+}, \mathrm{Na}^{+}, \mathrm{OH}^{-}\right)$na solução

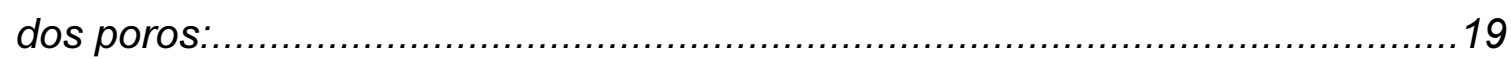

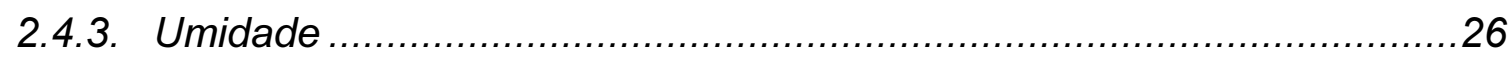

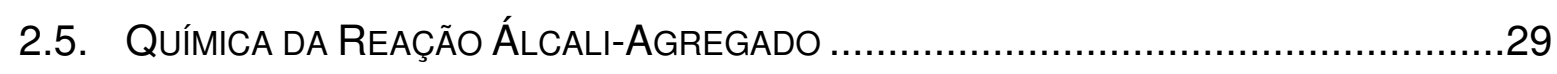

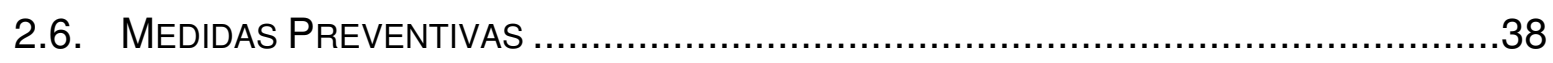

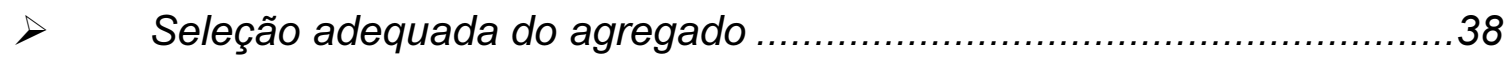




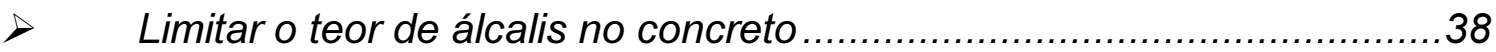

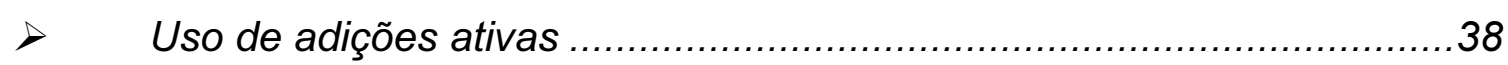

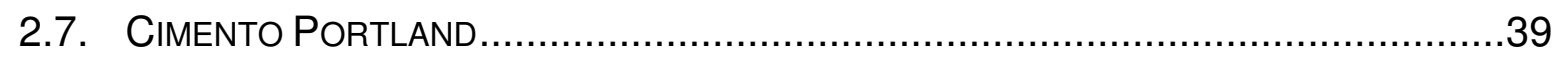

2.7.1. Clínquer Portland .......................................................... 39

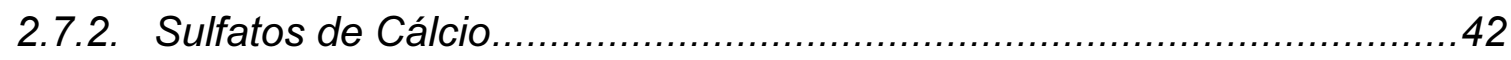

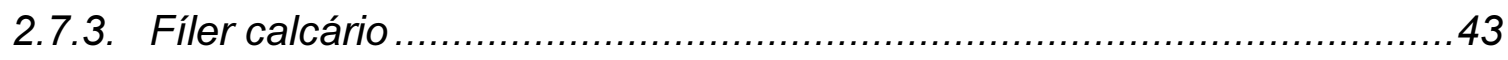

2.7.4. Adições Ativas ao Cimento Portland ............................................ 44

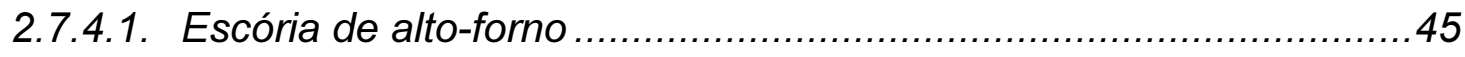

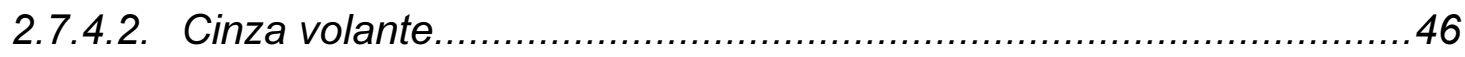

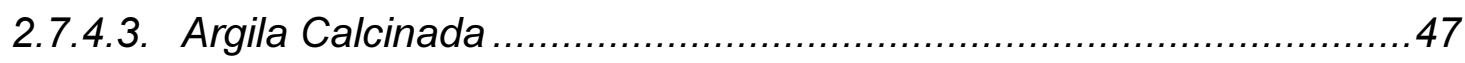

2.7.5. Adições ativas ao Concreto ............................................... 48

2.7.5.1. Sílica Ativa ................................................................... 48

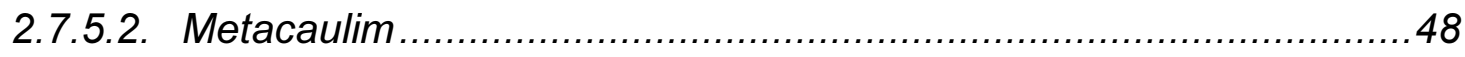

2.7.6. Tipos de Cimento Portland ................................................. 49

2.7.7. Composição dos Cimentos Industriais em 2003..............................51

2.8. MECANISMO de MinimizaÇÃo da RAS das AdiçõES ATIVAS .............................53

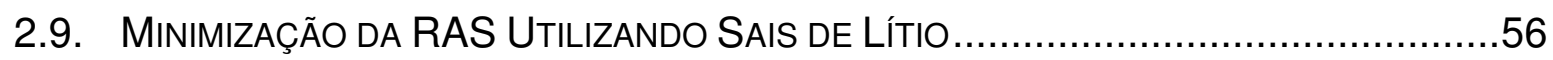

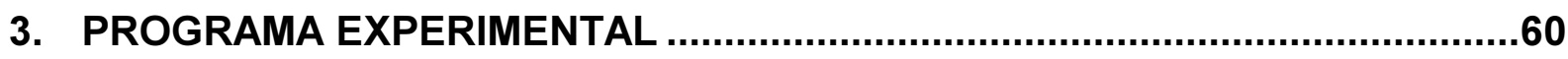

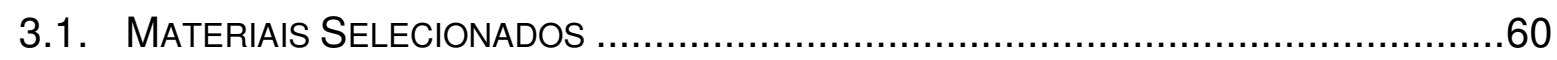

3.2. Metodologia de Caracterização dos Materiais....................................62

3.3. Determinação da Reatividade dos Agregados (ASTM C 1260) .................64

3.4. DeterminaÇÃo da Eficiência dos Cimentos Com Adições Ativas em

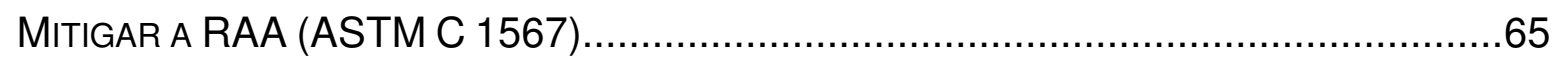

3.5. CARActerizaÇÃo das BarRas de ARgamaSSA ...................................66

4. RESULTADOS DA CARACTERIZAÇÃO DOS MATERIAIS ..........................69

4.1. ComposiçÃo QuÍMICA dOS AgLOMERANTES ........................................69

4.2. ComposiçÃo Mineralógica dos AglomeranteS ....................................70

4.3. CaracterizaÇÃo Físıco-MECÂNICA dos AgLomeranteS ..........................71 


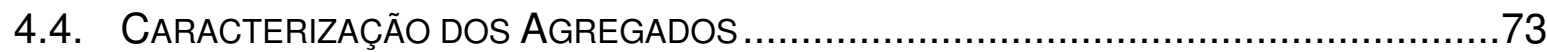

5. RESULTADOS DOS ENSAIOS DE REATIVIDADE .....................................79

5.1. Avaliação da Eficiência dos Cimentos com Adições Ativas na

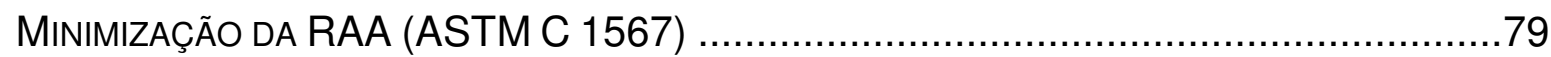

5.2. Efeito das Adições Ativas nas Propriedades MeCÂNiCaS..........................88

5.3. ANÁLISE TÉRMICA E TERMOGRAVIMÉtricA DAS BARRAS DE ARGAMASSA ...........90

5.4. Teor de Álcalis das BarRas de ArgamasSA .....................................

5.5. Porosimetria Por Intrusão de MercúRIO das BarRas de ARGamassa ........92

5.6. AnÁlise Microscópica das BarRas de ARgamaSSA .................................95

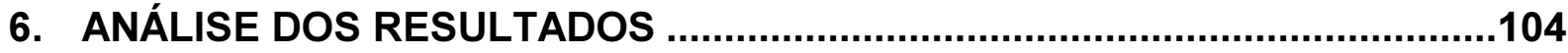

7. CONSIDERAÇÕES FINAIS ...................................................................111

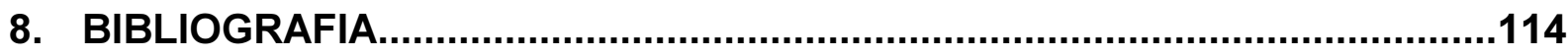

APÊNDICE A - MÉTODOS DE ENSAIO E EQUIPAMENTOS DE

CARACTERIZAÇÃO DOS MATERIAIS EMPREGADOS .....................................122

APENDICE B - CARACTERIZAÇÃO DOS MATERIAIS - RESULTADOS .............126

Cimento PortLANd de Alta ResistêncIa InICIAL - CP V-ARI............................126

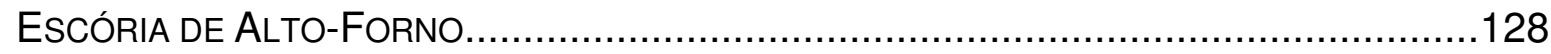

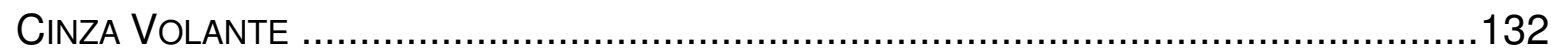

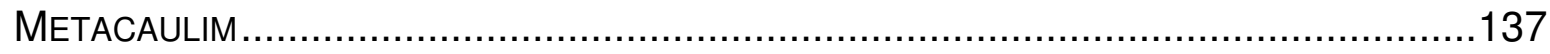

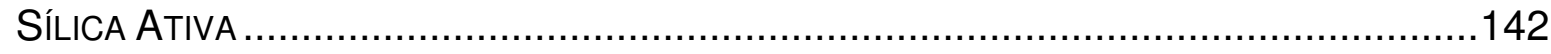

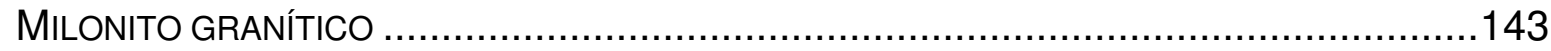

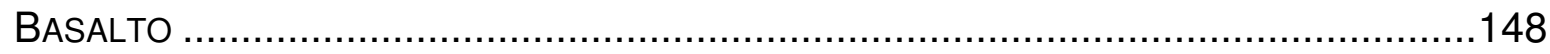

APÊNDICE C - RESULTADOS INDIVIDUAIS DE EXPANSÃO.............................153

APÊNDICE D - CARACTERIZAÇÃO DAS BARRAS DE ARGAMASSA................161 


\section{INTRODUÇÃO}

A durabilidade das estruturas de concreto está diretamente ligada aos materiais, aos processos construtivos, às propriedades físicas, às condições de exposição e aos tipos de solicitação.

A qualidade dos materiais (cimento, agregados miúdo e graúdo, água e aditivos) pode influenciar a durabilidade, uma vez que a interação desses materiais é que vai conferir ao concreto determinadas propriedades ligadas à sua vida útil.

A durabilidade do concreto está relacionada à maior ou menor capacidade do concreto de resistir às agressões químicas, físicas, mecânicas e biológicas do ambiente para o qual foi projetado ou aos mecanismos internos do próprio concreto. Dentre as agressões químicas destacam-se os ataques por íons cloreto e sulfato, dióxido de carbono, ataques ácidos e as reações álcali-agregado.

A reação entre os hidróxidos alcalinos solubilizados na fase líquida dos poros do concreto e alguns agregados reativos é lenta, resultando em um gel que, ao se acumular nos vazios e na interface pasta-agregado, na presença de água, se expande, exercendo pressão interna no concreto. Ao exceder a sua resistência à tração, a pressão interna pode promover fissurações. As fissurações aumentam a permeabilidade, permitindo que mais água/umidade difunda no concreto, o que acelera a reação álcali-agregado, tornando-o mais vulnerável a outros fenômenos patológicos e comprometendo a qualidade da estrutura.

A reação álcali-agregado requer a atuação conjunta de água, agregado reativo e álcalis. Sua prevenção pode ser feita a partir da eliminação de um dos fatores, ou seja, a partir do emprego de agregados inertes ou de cimentos com baixos teores de álcalis ou impedir a difusão da umidade. Entretanto, a eliminação de um desses fatores normalmente não é técnica e economicamente viável.

Dentre as medidas preventivas para o emprego de agregados reativos em obras de construção civil, destacam-se a utilização de cimentos com baixos teores de álcalis ou a de cimentos com adições ativas mitigadoras da reação álcali-agregado: escória de alto-forno, cinza volante, metacaulim e sílica ativa. 
A cinza volante é uma pozolana eficiente na minimização da reação álcali-agregado, quando presente no cimento Portland em teores de 25 a 35\%. Escórias de alto-forno presentes nos cimentos em teores acima de 50\%, sílica ativa, em teores de 10 a $12 \%$, e metacaulim, em teores próximos de $10 \%$, também têm sido relatados como eficientes na redução da reação (Malvar et al., 2002).

Os teores mínimos dessas adições ao cimento Portland podem variar em função do grau de reatividade do agregado, do teor de álcalis no cimento, da qualidade desses materiais, bem como dos mecanismos de redução da expansão.

No Brasil são produzidos sete tipos básicos de cimento, os quais, além de clínquer e sulfato de cálcio, podem conter adições de fíler calcário, escória de alto-forno e materiais pozolânicos (cinza volante ou argila calcinada) em diferentes teores. Os cimentos mais eficientes na minimização da reação álcali-agregado são os de altoforno (CP III) e os pozolânicos (CP IV), que representam 18\% e 7\% da produção nacional em 2005, respectivamente. Os outros tipos de cimento, representam $75 \%$ da produção nacional (SNIC, 2005).

A presença de escória de alto-forno e materiais pozolânicos em alguns tipos de cimento não garante a minimização da reação álcali-agregado, pois essa dependerá também do teor em que a adição está presente, do grau de reatividade do agregado e do teor total de álcalis no concreto. Por outro lado, esses cimentos com adições não estão disponíveis em todas as regiões do território nacional, pois sua produção depende da disponibilidade de escória de alto-forno e de materiais pozolânicos.

As escórias de alto-forno, materiais pozolânicos e sílica ativa são mitigadores tradicionais, porém, mais recentemente, sais de lítio como $\mathrm{LiOH}, \mathrm{Li}_{2} \mathrm{CO}_{3}$, $\mathrm{LiF}, \mathrm{LiNO}_{3}$, $\mathrm{LiNO}_{2}, \mathrm{Li}_{2} \mathrm{SO}_{4}$ vêm se destacando na prevenção e no controle da reação álcaliagregado já instalada (Feng et al., 2005).

Pesquisas indicam que $\mathrm{LiNO}_{3}$, por ser sal neutro, solúvel, e não aumentar a concentração de íons $\mathrm{OH}^{-}$, é o mais promissor na minimização da reação álcalisílica (Diamond, 1999). 
Os problemas da engenharia civil surgem quando em determinada região só há agregados reativos e cimentos não-mitigadores da reação álcali-agregado. No caso das grandes obras de infra-estrutura, como as barragens, são realizados estudos preliminares dos materiais e adotadas medidas preventivas, como o uso de cimentos com teores adequados de escória de alto-forno, ou materiais pozolânicos ou, ainda, adição de metacaulim ou sílica ativa ao concreto.

Em obras correntes de engenharia civil, os tecnologistas de concreto deveriam ter postura semelhante selecionando os materiais empregados e tomando as devidas precauções para reduzir os riscos de reação álcali-agregado nas estruturas de concreto.

Quando o agregado é reativo e há disponibilidade de cimentos com escória ou materiais pozolânicos, a questão é saber se o teor presente é suficiente para mitigar a reação álcali-agregado. Em caso contrário, qual seria esse teor?

Outra questão a ser levantada é se a expansão é reduzida em um meio em que há disponibilidade de álcalis, qual dos fatores normalmente mencionados na literatura (diluição dos álcalis, retenção dos álcalis na estrutura do C-S-H, redução da alcalinidade da solução dos poros ou redução da permeabilidade) seria o principal responsável pela minimização da expansão.

A resposta está na compreensão dos efeitos de minimização da reação álcaliagregado de cimentos com adição de escória de alto-forno, cinza volante, metacaulim e sílica ativa, e avaliação do grau de eficiência de cada uma dessas adições.

Para efeitos dessa dissertação, grau de eficiência refere-se ao teor mínimo de adições ativas ao cimento Portland para minimizar a expansão para valores inferiores a $0,10 \%$ aos 14 dias de cura em solução alcalina, conforme preconiza a ASTM C 1567. 


\subsection{Estrutura do Trabalho}

Para responder as questões mencionadas, o trabalho apresenta inicialmente a revisão bibliográfica, incluindo os tipos de RAA, condições para ocorrer a reação, fases reativas presentes nos agregados, química da RAA, medidas preventivas, mecanismos de minimização da RAA com as adições ativas, cimento Portland e suas adições.

No programa experimental foram analisados dois tipos de agregado potencialmente reativos com os álcalis: basalto e milonito granítico. O primeiro, proveniente de rocha ígnea, tem como constituintes deletérios vidro, clorofeíta, calcedônia (sílica criptocristalina), que dará origem à reação do tipo álcali-sílica. $\mathrm{O}$ agregado milonito granítico provém de rocha metamórfica e tem como constituintes deletérios quartzo microgranular, quartzo recristalizado, quartzo com extinção ondulante e quartzo e feldspato deformados, que dará origem ao tipo de reação álcali-sílicato.

A utilização desses agregados em concretos com cimentos não-mitigadores, associada à presença de umidade, pode acarretar o desenvolvimento da reação álcali-agregado, o que comprometerá a durabilidade do concreto.

Para mitigar as reações álcali-agregado das amostras selecionadas foram testados quinze tipos de cimento, preparados em laboratório com quatro adições ativas normalmente utilizadas nos cimentos e concretos brasileiros (escória de alto-forno, cinza volante, metacaulim e sílica ativa), como também um cimento industrial (CP V-ARI), sem adição.

Os agregados milonito granítico e o basalto foram ensaiados pelo método acelerado das barras de argamassa ASTM C 1260, para determinar o grau de reatividade, e ASTM C 1567, indicado para avaliar a eficiência das adições ativas, no qual a expansão é reduzida à medida que o teor de adição aumenta no cimento Portland. 
Todos os materiais utilizados foram caracterizados química, física e mineralogicamente, incluindo a análise petrográfica dos agregados. Após a realização dos ensaios acelerados, as barras de argamassa foram caracterizadas por análise química, com o objetivo de avaliar a migração de íons de sódio da solução para a argamassa, análises térmicas, para determinar o teor de hidróxido de cálcio residual, análise porosimétrica por intrusão de mercúrio, para avaliar a influência das adições ativas no refinamento do tamanho dos poros e análise de determinação das resistências à compressão e tração na flexão, para avaliar os efeitos das adições ativas no desempenho mecânico.

Ensaios ao microscópio estereoscópico, microscópio óptico de luz transmitida em lâminas delgadas e ao microscópio eletrônico de varredura foram realizados com o objetivo de confirmar a RAA e verificar se há diferenças nos produtos da reação álcali-silicato e álcali-sílica.

\subsection{Objetivo}

Determinar o grau de reatividade dos agregados, identificar as fases reativas e investigar a eficiência de cimentos Portland com adições ativas (escória de altoforno, cinza volante, metacaulim e sílica ativa) na minimização da reação álcaliagregado através dos ensaios acelerados em barras de argamassa imersas em solução alcalina $1 \mathrm{~N}$ de $\mathrm{NaOH}$ a $80^{\circ} \mathrm{C}$.

Comparar os efeitos das adições ativas na minimização das reações álcali-sílica e álcali-silicato visando compreender o mecanismo de minimização da expansão.

\subsection{Justificativa}

A reação álcali-agregado afeta grande número de obras de construção civil, causando danos desde moderados a severos. Nos casos de danos moderados, o monitoramento periódico e a manutenção das estruturas de concreto podem ser adequados para o controle da patologia. Nos casos mais severos, requer-se a substituição dos elementos afetados, devido ao comprometimento das propriedades mecânicas do concreto. 
A melhor forma de prevenir a patologia referente à reação álcali-agregado é determinar a reatividade do agregado antes de ser usado no concreto e, a partir dessa avaliação, selecionar o cimento Portland mais adequado.

Se o cimento disponível na região não for mitigador da reação e caso seja inviável adquiri-lo em outra região, metacaulim e sílica ativa tornam-se opções técnica e economicamente viáveis. Nesse caso, para o tipo de cimento e agregado disponíveis, quais seriam os teores adequados para mitigar a reatividade do agregado?

Em resumo, a pesquisa visa avaliar se as adições ativas apresentam comportamentos distintos na minimização da reação álcali-silicato e álcali-sílica, a eficiência de cada uma e o mecanismo. 


\section{A REAÇÃO ÁLCALI-AGREGADO - DADOS DE LITERATURA}

A reação álcali-agregado foi descrita inicialmente por Stanton, em 1940, na Califórnia (Stanton, 1940), que demonstrou que a expansão e as fissurações observadas nos pavimentos de concreto estavam relacionadas à reação química entre alguns minerais constituintes dos agregados e os hidróxidos alcalinos liberados durante as reações de hidratação do cimento Portland.

Durante as décadas seguintes, as pesquisas sobre RAA foram realizadas em vários países, destacando-se os Estados Unidos, que estabeleceram a maioria dos princípios básicos, Canadá, alguns países europeus, Japão, China e Índia.

A reação álcali-agregado ocorre principalmente em estruturas de concreto em contato com a água, tais como: obra hidráulica, barragem, ponte, pavimento, fundação,entre outras.

\subsection{A Reação Álcali-Agregado no Concreto}

A ocorrência de reação álcali-agregado no concreto manifesta-se através de padrões de fissuramento típico não orientados, formando desenhos quadrangulares e hexagonais, principalmente nas regiões não-armadas da peça (fissuração tipo "mapa"). Na presença de armadura, as fissuras se orientam no sentido da armação (Kuperman et al., 1997; Pecchio et al., 2006).

Hasparyk (2005) relacionou os principais efeitos deletérios provocados pela reação álcali-agregado:

> fissuração na superfície do concreto e entre camadas de concretagem;

desplacamentos na superfície do concreto;

perda de estanqueidade;

descolamento (perda de aderência) da argamassa junto à superfície dos agregados;

movimentação (abertura ou deslocamento relativo) de juntas de contração;

abertura de juntas de construção, com fissuras horizontais; 
$>$ movimentação/desalinhamento das superfícies livres (ex: alteamento da crista da barragem e soleiras de vertedouros, deflexões para montante nas estruturas de barragens);

> travamento ou deslocamento de equipamentos e peças móveis (por exemplo: comportas, turbinas, eixos, pistões, etc.).

\subsection{Reação Álcali-Agregado no Brasil}

Kihara e Scandiuzzi (1993) mencionam que os primeiros trabalhos sobre RAA no Brasil são da década de 60, com a construção da Barragem de Jupiá, cujo cascalho do Rio Paraná tinha a fase reativa calcedônia. Para viabilizar a utilização desse agregado, construiu-se no canteiro de obras de Jupiá uma fábrica de pozolana a partir da argila caulinítica disponível na região, que após calcinação era adicionada ao cimento Portland no teor de $35 \%$.

Em 1985 foi divulgado o primeiro caso em barragem: Usina Hidroelétrica Apolônio Sales de Oliveira (Moxotó). Em 1988 foi confirmada a presença de reação na Barragem de Joanes II (BA). Na década de 90 constatou-se a ocorrência de RAA em várias barragens. Em todos os casos investigados a reação era do tipo álcalisilicato.

Kihara, Sbrighi Neto e Kuperman (1998) sintetizaram as principais estruturas hidráulicas com evidências de reação álcali-agregado no mundo. A Tabela 1 apresenta as estruturas com RAA no Brasil, complementada com informações de outros trabalhos. 
Tabela 1 - Estruturas hidráulicas de concreto no Brasil com reação álcali-agregado

\begin{tabular}{|c|c|c|c|c|}
\hline $\begin{array}{l}\text { Nome da } \\
\text { Estrutura }\end{array}$ & $\begin{array}{l}\text { Tipo de } \\
\text { estrutura }\end{array}$ & $\begin{array}{l}\text { Fim da } \\
\text { construção }\end{array}$ & $\begin{array}{l}\text { RAA notada } \\
\text { no ano }\end{array}$ & $\begin{array}{l}\text { Tipo de } \\
\text { agregado }\end{array}$ \\
\hline Billings-Pedras & Barragem & 1936 & 1992 & Granito $^{1}$ \\
\hline Furnas & Barragem & 1963 & 1976 & Quartzito $^{1}$ \\
\hline Ilha dos Pombos & Barragem & 1924 & 1991 & Gnaisse $^{1}$ \\
\hline Jaguara & Barragem & 1971 & 1996 & $\begin{array}{l}\text { Quartzito }^{1} \\
\text { Granito }^{2}\end{array}$ \\
\hline Joanes II & Barragem & 1971 & 1988 & Gnaisse $^{1}$ \\
\hline Jurupará & Barragem & 1937 & - & $\begin{array}{l}\text { Gnaisse }^{1} \\
\text { Biotita granito }^{2}\end{array}$ \\
\hline $\begin{array}{l}\text { Mascarenhas de } \\
\text { Moraes }\end{array}$ & Barragem & 1957 & - & Quartzito $^{3}$ \\
\hline Moxotó & Casa de Força & 1974 & 1980 & Granito-gnaisse $^{1}$ \\
\hline Paulo Afonso I & Barragem & 1955 & 1978 & Granito-gnaisse $^{1}$ \\
\hline Paulo Afonso II & Barragem & 1962 & 1978 & Granito-gnaisse ${ }^{1}$ \\
\hline Paulo Afonso III & Barragem & 1973 & 1978 & Granito-gnaisse $^{1}$ \\
\hline Paulo Afonso IV & Barragem & 1979 & 1985 & Granito-gnaisse $^{1}$ \\
\hline Pedro-Beicht & Barragem & 1932 & 1991 & Granito-gnaisse $^{1}$ \\
\hline Peti & Barragem & 1945 & 1964 & Gnaisse $^{1}$ \\
\hline Porto Colômbia & $\begin{array}{l}\text { Vertedouro e } \\
\text { Casa de Força }\end{array}$ & 1973 & 1985 & $\begin{array}{l}\text { Cascalho e } \\
\text { basalto }^{3}\end{array}$ \\
\hline Sá Carvalho & Barragem & 1951 & & Gnaisse $^{1}$ \\
\hline Tapacurá & Barragem & 1975 & 1990 & - \\
\hline Traição & Usina Elevatória & 1940 & 1980 & Milonito $^{1}$ \\
\hline Túnel 6 & Tomada d'água & 1974 & 1989 & Granito-gnaisse $^{1}$ \\
\hline
\end{tabular}

1) Andriolo (2000);

2) Alves et al. (1997);

3) Veiga, Gonçalves e Hasparyk (1997).

No Brasil, a reação álcali-agregado estava restrita às obras hidráulicas. Em 2005, constatou-se a ocorrência em blocos de fundações em edifícios urbanos, principalmente residenciais, em Recife/PE, numa escala inédita para o meio técnico de todo o mundo. Baixa profundidade do lençol freático, presença de fases reativas nos agregados (quartzo com extinção ondulante e quartzo microgranular) e disponibilidade de álcalis contribuíram para a ocorrência da reação. A Foto 1 ilustra o quadro fissuratório dos blocos de fundação (Pecchio et al. 2006). 


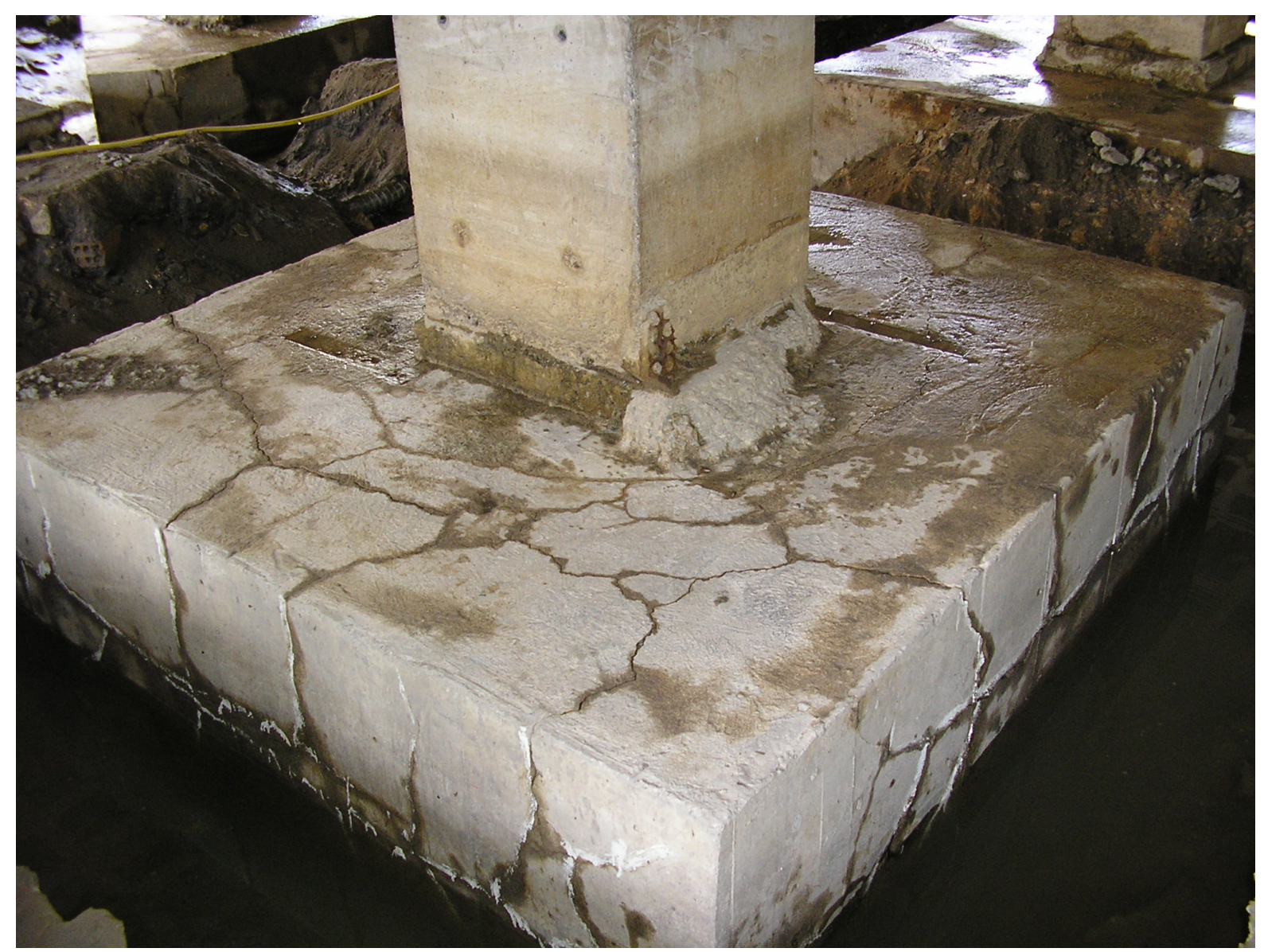

Foto 1 - Bloco de fundação com padrão de fissuração típico de RAA (Pecchio et al., 2006)

Andrade et al. (2006) avaliaram o potencial de reatividade dos agregados miúdos e graúdos da Região Metropolitana do Recife e concluíram que a maioria dos agregados analisados apresentava fases potencialmente reativas que efetivamente contribuíram para a ocorrência da reação, principalmente nos blocos de fundação.

A Região do Grande Recife/PE é conhecida geologicamente como Província da Borborema, caracterizada pela presença de zonas de cisalhamento em escala continental. Agregados procedentes dessas zonas de cisalhamento têm maior probabilidade de apresentar fases minerais reativas com os álcalis (Neves, S.P. 1991; Neves B.B.B. et al., 2001). 


\subsection{Tipos de Reação Álcali-Agregado}

A reação álcali-agregado compreende três tipos, em função da composição mineralógica dos agregados e do mecanismo envolvido: reação álcali-sílica, reação álcali-silicato e reação álcali-carbonato (Kihara, Scandiuzzi, 1993).

Reação álcali-sílica (RAS): tipo em que participam a sílica reativa dos agregados e os hidróxidos alcalinos, na presença do hidróxido de cálcio originado pela hidratação do cimento, formando um gel expansivo. Constituem exemplos de sílica reativa: opala, tridimita, cristobalita, vidro vulcânico, entre outros. Esse é o tipo de reação álcali-agregado que mais rapidamente se desenvolve.

Reação álcali-silicato: tipo específico de RAS em que participam os álcalis e alguns tipos de silicatos presentes em certas rochas. Os silicatos reativos mais comuns são quartzo tensionado por processos tectônicos e minerais da classe dos filossilicatos presentes em ardósias, filitos, xistos, milonitos, granulitos, quartzitos, entre outros. Geralmente, essa reação é mais lenta do que a reação álcali-sílica (RAS).

Reação álcali-carbonato $(R A C)$ : tipo de reação álcali-agregado em que participam os álcalis e agregados rochosos carbonáticos. A forma mais conhecida de deterioração do concreto é devida à desdolomitização da rocha e conseqüente enfraquecimento da ligação pasta-agregado. Não há formação de gel expansivo, mas de compostos cristalizados como brucita, carbonatos alcalinos, carbonato cálcico e silicato magnesiano. Como a reação regenera os hidróxidos alcalinos, a desdolomitização terá continuidade até que a dolomita tenha reagido por completo ou a fonte de álcalis se esgote.

No presente trabalho, a reação álcali-carbonato não será tratada em maiores detalhes por não ser escopo da pesquisa. O termo reação álcali-agregado (RAA) quando mencionado no texto refere-se as reações álcali-sílica e álcali-silicato indistintamente. 


\subsection{Condições para Ocorrer a Reação}

Três condições são necessárias para iniciar a reação álcali-agregado no concreto: 1) presença de fases reativas no agregado, 2) umidade suficiente, 3) concentração de hidróxidos alcalinos $\left(\mathrm{K}^{+}, \mathrm{Na}^{+}, \mathrm{OH}^{-}\right)$na solução dos poros do concreto suficiente para reagir com as fases reativas dos agregados. Na ausência de um desses fatores, a reação não ocorrerá ( $\mathrm{ACl}$ 221.1R, 1998; Mather, 1999).

\subsubsection{Fases reativas no agregado}

Para ocorrer a RAA o agregado deve conter formas de sílica capazes de reagir quimicamente com o íon hidroxila e os álcalis presentes na solução dos poros, tais como: vidro vulcânico, sílica amorfa, sílica microcristalina, sílica criptocristalina, tridimita, cristobalita, calcedônia, opala, quartzo e feldspato deformados.

Os silicatos representam a maior e mais importante classe de minerais formadores de rochas, destacando-se os tectossilicatos, que constituem mais de $60 \%$, em volume, das rochas da crosta terrestre. Os tectossilicatos são constituídos por átomos de silício e oxigênio, arranjados em retículos cristalinos, na forma de unidades tetraédricas básicas dos silicatos $\left(\mathrm{SiO}_{4}\right)^{4-}$ (Dana, 1969, Vlach, 2002).

Nos tetraedros, um átomo de sílicio está ligado a quatro átomos de oxigênio em proporção constante $\mathrm{Si}: \mathrm{O}=1: 2$, e são eletricamente neutros. As ligações Si-O nos tetraedros contêm contribuições covalente e iônica em proporções similares e muito fortes. Cada átomo de oxigênio está sempre compartilhado por dois tetraedros adjacentes, formando uma rede tridimensional contínua com o mais alto grau de polimerização possível para as unidades fundamentais. O tipo de estrutura cristalina formada depende da temperatura e pressão existentes no momento da cristalização. (Dana, 1969 e Vlach, 2002). 
A reatividade dos componentes silicosos com os hidróxidos alcalinos depende da:

Granulação: quanto menor o tamanho dos cristais (microcristalino ou criptocristalino) maior será a superfície de contato e, conseqüentemente, maior será a reatividade da fase;

Estrutura cristalina: quanto mais desorganizada e instável, mais reativa será a fase. Vidro e opala (amorfos), calcedônia (microcristalina ou criptocristalina), tridimita e cristoblatita (metaestáveis) e quartzo e feldspato tensionados se destacam como as fases mais reativas com os álcalis;

Conteúdo de água de cristalização: mais precisamente grupos de silanóis $(\mathrm{Si}-\mathrm{OH})$, presentes nos materiais silicosos conferem maior reatividade às fases (Kihara e Scandiuzzi, 1993).

As principais fases mineralógicas potencialmente reativas encontradas nos agregados, obtidos a partir de rochas ígneas, sedimentares e metamórficas, foram sintetizadas por Hasparyk (1999), como consta da Tabela 2. 
Tabela 2 - Agregados e fases mineralógicas potencialmente reativas (Hasparyk, 1999).

\begin{tabular}{|c|c|c|}
\hline \multicolumn{2}{|c|}{ Tipo de agregado } & \multirow{2}{*}{$\begin{array}{l}\text { Fase mineralógica potencialmente reativa } \\
\text { > vidro vulcânico ácido a intermediário, tridimita e minerais } \\
\text { de alteração (vidro devitrificado) }\end{array}$} \\
\hline \multirow{5}{*}{ 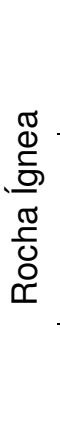 } & $\begin{array}{l}\text { Andesito, dacito, fonólito, latito, } \\
\text { obsidiana, pedra púmice, riolito, } \\
\text { traquito e tufo vulcânico }\end{array}$ & \\
\hline & Basalto $^{(*)}$ & > vidro vulcânico básico \\
\hline & & calcedônia, cristobalita e opala \\
\hline & & $>$ minerais de alteração (clorofeíta) \\
\hline & $\begin{array}{l}\text { Granito } \\
\text { Granodiorito }\end{array}$ & $\begin{array}{l}>30 \% \text { de quartzo tensionado, com ângulo de extinção } \\
\text { ondulante }>25^{\circ} \text { e minerais de alteração }\end{array}$ \\
\hline \multirow{8}{*}{ 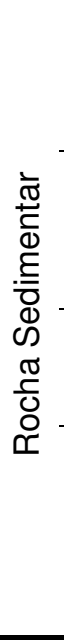 } & Arenito & $\begin{array}{l}\text { 7. }>30 \% \text { de quartzo tensionado, com ângulo de extinção } \\
\text { ondulante }>25^{\circ}\end{array}$ \\
\hline & & 7. opala e calcedônia \\
\hline & Calcário & $\begin{array}{l}\text {. relação calcita/dolomita próxima a } 1 \text { e quando associado a } \\
\text { argilominerais (filossilicatos) }\end{array}$ \\
\hline & & $>$ opala, calcedônia \\
\hline & Chert & $\begin{array}{l}>\text { opala e calcedônia } \\
\text { sílica criptocristalina }\end{array}$ \\
\hline & Grauvaca & $\begin{array}{l}\text { 7. } 30 \% \text { de quartzo tensionado, com ângulo de extinção } \\
\text { ondulante }>25^{\circ} \text { e quartzo microcristalino a criptocristalino }\end{array}$ \\
\hline & & >. argilominerais (filossilicatos) \\
\hline & & D. opala \\
\hline \multirow{8}{*}{ 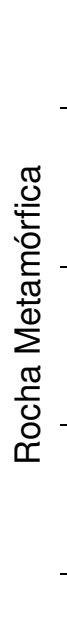 } & Ardósia & ᄀ. quartzo tensionado \\
\hline & & $>$ argilominerais (filossilicatos) \\
\hline & Filito & $\begin{array}{l}>30 \% \text { de quartzo tensionado, com ângulo de extinção } \\
\text { ondulante }>25^{\circ} \text { e quartzo microcristalino a criptocristalino }\end{array}$ \\
\hline & & . vermiculita (filossilicatos) \\
\hline & Hornfel & $\begin{array}{l}\text { 7. }>30 \% \text { de quartzo tensionado, com ângulo de extinção } \\
\text { ondulante }>25^{\circ} \text { e quartzo microcristalino a criptocristalino }\end{array}$ \\
\hline & & 7. vermiculita (filossilicatos) \\
\hline & $\begin{array}{l}\text { Gnaisse, granulito, micaxisto, } \\
\text { quartzito e xisto }\end{array}$ & $\begin{array}{l}\text { 7. }>30 \% \text { de quartzo tensionado, com ângulo de extinção } \\
\text { ondulante >25\%, feldspato deformado e quartzo de } \\
\text { granulação fina }\end{array}$ \\
\hline & Milonito ${ }^{(*)}$ & $>$ quartzo tensionado e de granulação fina \\
\hline
\end{tabular}

$\left(^{*}\right)$ Tipo de agregado utilizado neste estudo

Como observado na Tabela 2, as principais fases reativas constituintes dos agregados são quartzo tensionado por esforços tectônicos e seus polimorfos tridimita e cristobalita. Destacam-se também as fases amorfas relacionadas com o processo de resfriamento rápido do magma, como vidro vulcânico, minerais de alteração, como clorofeita, e sílica hidratada - opala. 
Todas essas fases são constituídas principalmente por $\mathrm{SiO}_{2}$ que, pelo seu alto teor confere caráter ácido às rochas. Essas fases, ao entrarem em contato com a solução fortemente alcalina dos poros, sofrem uma reação do tipo ácido-base cujo produto de reação é um gel sílico-alcalino que, ao absorver água, expande, gerando pressão interna no concreto e causando fissuramento.

A estrutura $\mathrm{SiO}_{2}$ dos silicatos pode compartilhar todos os átomos de oxigênio em oito arranjos geométricos diferentes, formando os oito polimorfos conhecidos de $\mathrm{SiO}_{2}$, sendo dois substâncias sintéticas. As variedades polimórficas mais conhecidas do grupo da sílica são quartzo, tridimita e cristobalita (Dana, 1969 e Vlach, 2002).

O quartzo é um dos mineral mais abundantes da crosta da Terra (aproximadamente $12 \%$ vol.) e está presente na maioria das rochas ígneas, metamórficas e sedimentares. Possui estrutura cristalina trigonal composta por tetraedros de sílica $\left(\mathrm{SiO}_{2}\right)$, fortemente unida, com alto grau de coesão e estável, não sendo atacada pela maioria de ácidos fortes ou álcalis (Dana, 1969).

A tridimita e a cristobalita são minerais de alta temperatura com estrutura cristalina mais aberta e menos densa, o que confere maior susceptibilidade à reação com os hidróxidos alcalinos (Glasser, 1992). A tridimita ocorre freqüentemente em rochas vulcânicas intermediárias a ácidas, tais como andesitos, dacitos e riolitos, enquanto a cristobalita aparece geralmente como produto de cristalização magmática tardia nessas rochas. (Dana, 1969 e Vlach, 2002).

As variedades criptocristalinas do quartzo são comuns na natureza e podem ser divididas em duas classes: fibrosas e granulares. Calcedônia é a denominação genérica que reúne as variedades criptocristalinas de baixa temperatura com hábito fibroso, como a ágata e o ônix. Sílex, chert, jaspe são exemplos das variedades microcristalinas de quartzo com hábito granular.

A opala é um mineralóide de sílica amorfa hidratada, com quantidade de água variável $\left(\mathrm{SiO}_{2} \cdot \mathrm{nH}_{2} \mathrm{O}\right)$, encontrada nas cavidades das rochas ígneas e sedimentares. (Dana, 1969 e Vlach, 2002). 
Silicatos amorfos também são formados por tetraedros de sílica, mas de forma desordenada, tornando a estrura aberta e imperfeita, e com maior área superficial de contato.

As fases vítreas, normalmente encontradas nas rochas ígneas, estão relacionadas ao resfriamento brusco e à viscosidade do magma, que impedem a migração e cristalização dos íons. As fases vítreas são metaestáveis e tendem a se cristalizar ou devitrificar.

A recristalização de minerais em uma rocha está relacionada a processos químicos, pelos quais grânulos de minerais instáveis se solubilizam e se recristalizam em novos minerais. A recristalização é indicativa da presença de substâncias instáveis no material (Dana, 1969).

A análise petrográfica realizada ao microscópio óptico de luz transmitida em lâminas delgadas permite caracterizar as rochas e identificar as principais fases mineralógicas potencialmente reativas com os álcalis. Agregados provenientes de rochas submetidas a esforços tectônicos normalmente apresentam cristais de quartzo e feldspato deformados, fraturados e microgranulares, devido à desintegração dos grânulos maiores. Esses esforços aumentam a entropia do retículo cristalino dos minerais, tornando-os mais instáveis e susceptíveis ao ataque por íons externos.

O quartzo é um mineral que se deforma muito facilmente frente a um campo de esforços dirigidos. Retículos cristalinos deformados perdem simetria em relação aos retículos normais e são facilmente evidenciados ao microscópio petrográfico por mostrarem extinções variáveis ou ondulantes. Na prática, observa-se que diferentes zonas de um mesmo grão se extinguem em posições diferentes da platina do microscópio, não havendo uma posição específica em que todo o grão fique homogeneamente extinto.

Retículos deformados são pouco estáveis e existe a tendência natural dos grãos deformados se recristalizarem sob a forma de agregados de vários cristais menores, homogêneos e não deformados (Vlach, 2002; Kihara 1986). Ilustrando dados da tabela são apresentados exemplos de agregados reativos nas Foto 2, Foto $3 \mathrm{e}$ Foto 4. 


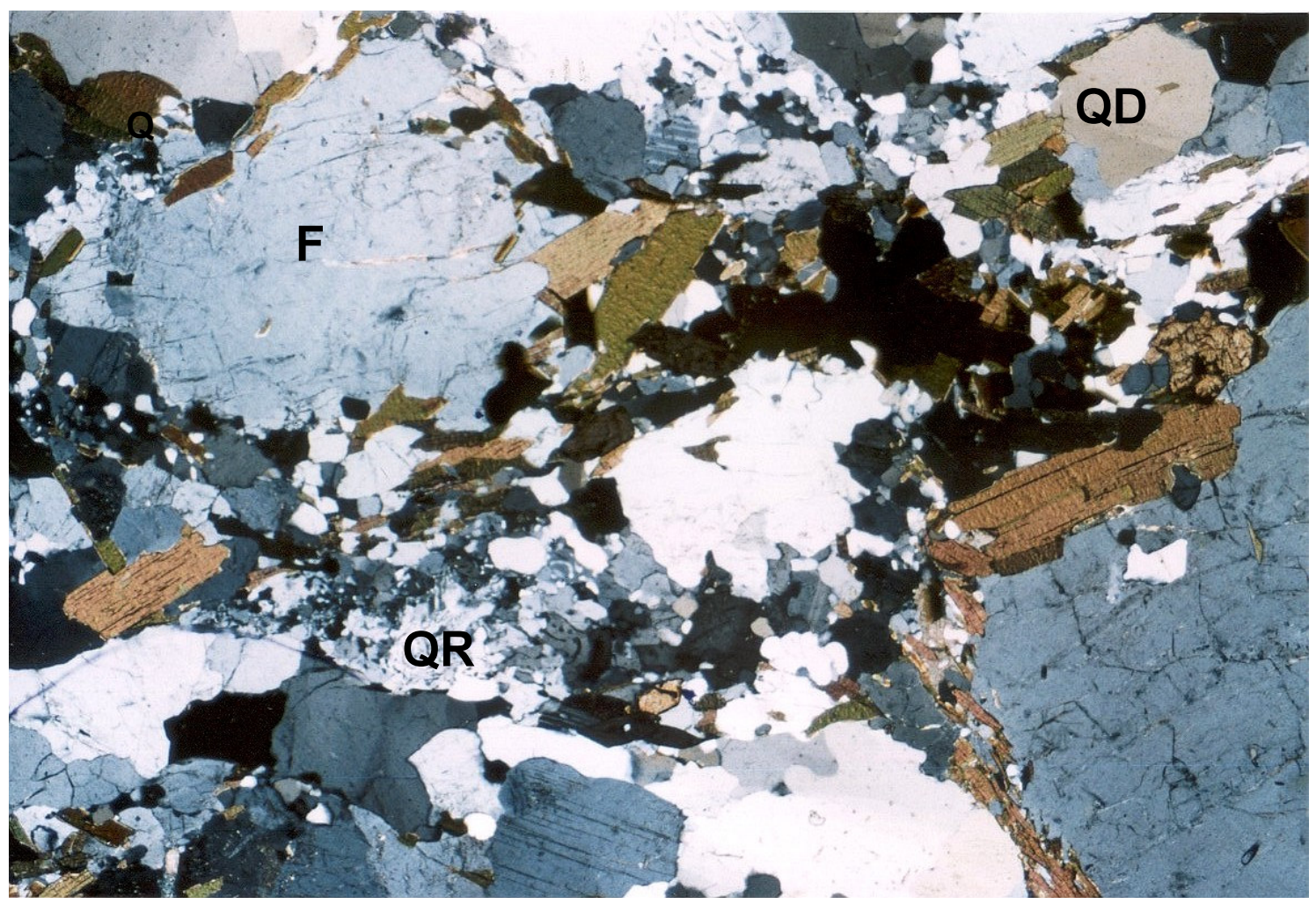

Foto 2 - Cristais de quartzo deformado (QD) que, associado a quartzo recristalizado (QR), conferem ao agregado caráter reativo. $(F=$ feldspato). Observado ao microscópio de luz transmitida. Ampliação 100x (Acervo ABCP).

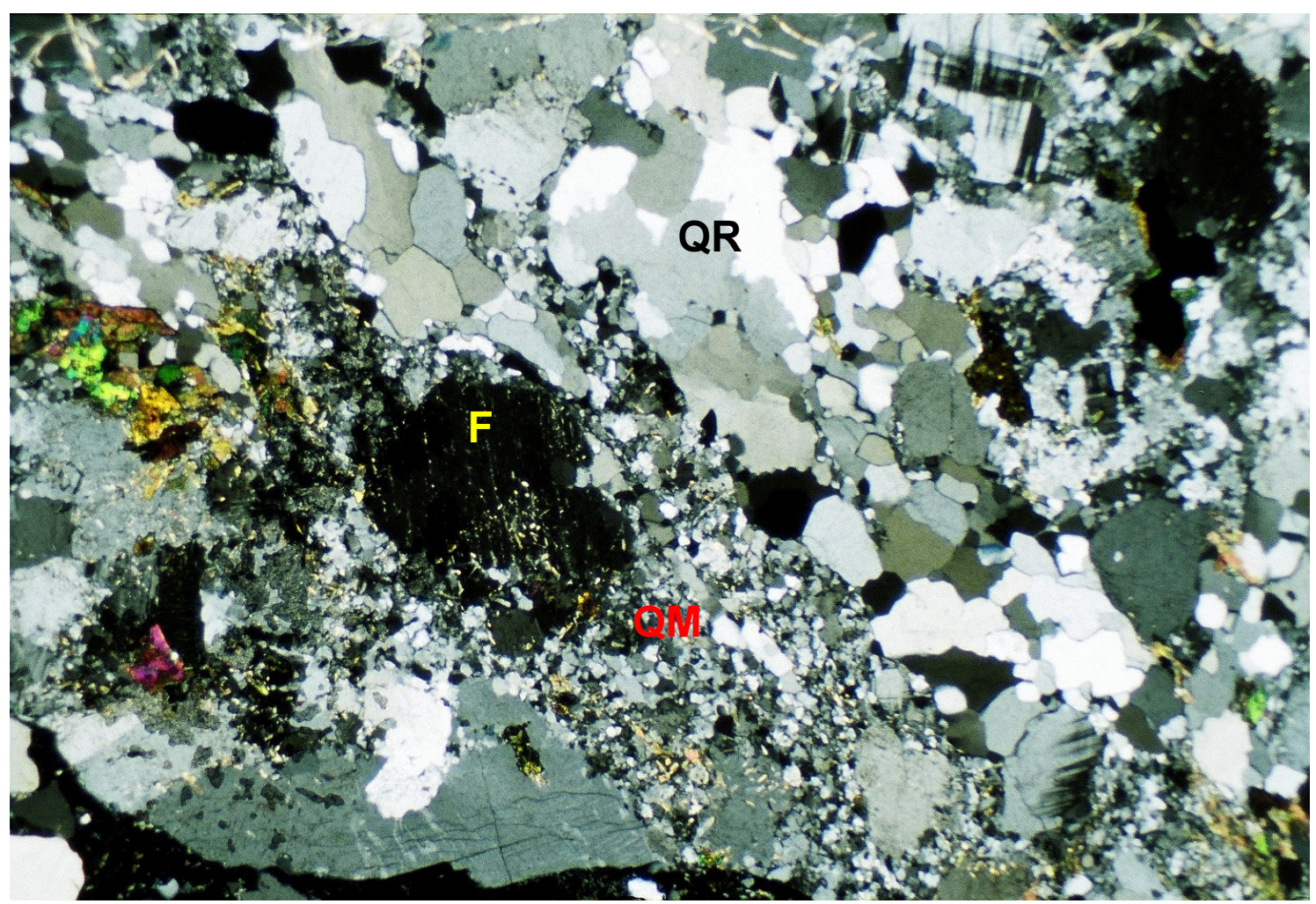

Foto 3 - Cristais de quartzo microcristalino (QM) que, associado a quartzo recristalizado (QR), conferem ao agregado caráter reativo. $(F=$ feldspato). Observado ao microscópio de luz transmitida. Ampliação 100x (Acervo ABCP). 


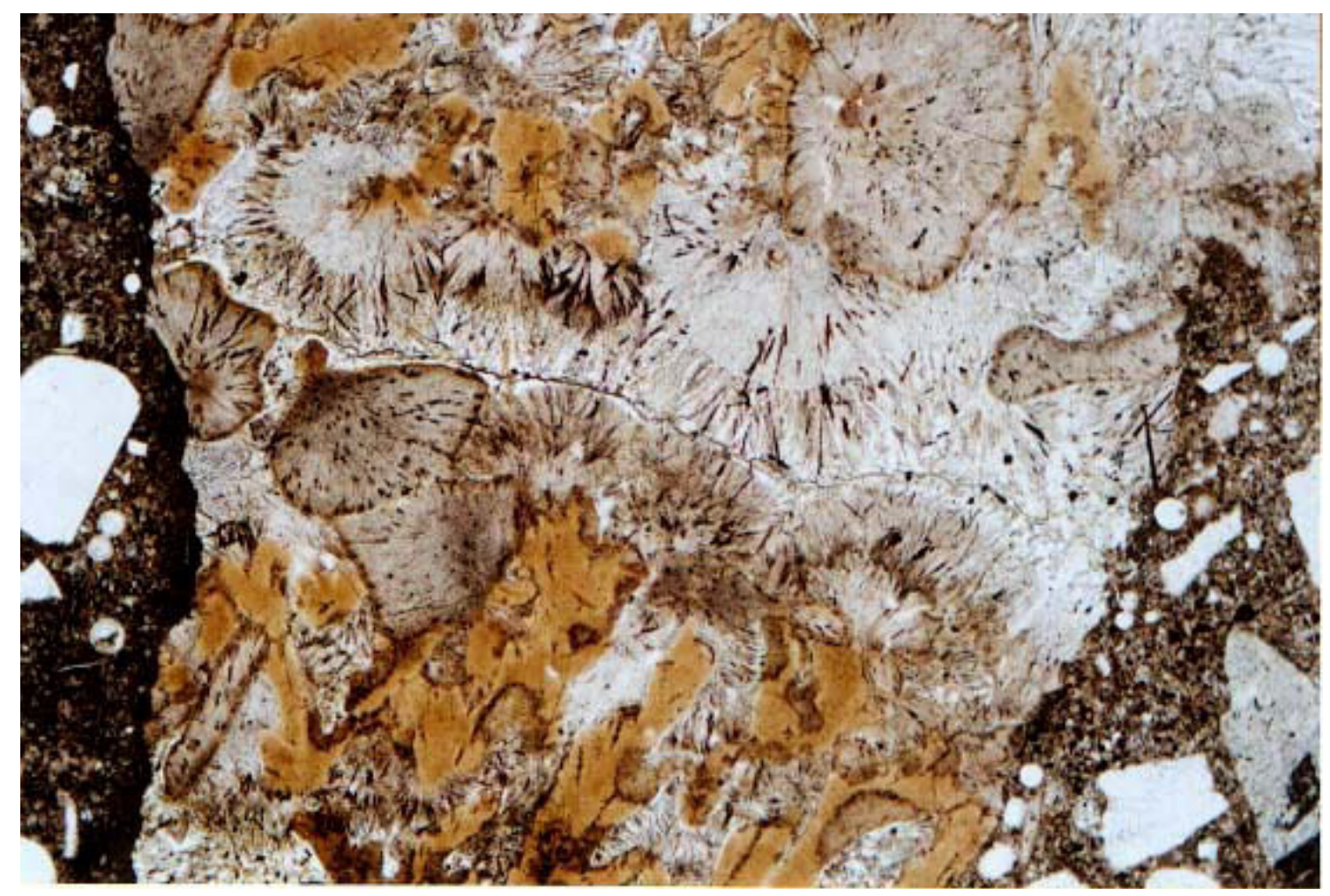

Foto 4 - Fase criptocristalina de calcedônia que confere ao material caráter reativo. Observada ao microscópio de luz transmitida. Ampliação 100x (FAA, 2004). 


\subsubsection{Concentração de hidróxidos alcalinos $\left(\mathrm{K}^{+}, \mathrm{Na}^{+}, \mathrm{OH}^{-}\right)$na solução dos poros:}

Os elementos metálicos lítio $(\mathrm{Li})$, sódio $(\mathrm{Na})$, potássio $(\mathrm{K})$, rubídio $(\mathrm{Rb})$, césio $(\mathrm{Cs})$ e frâncio (Fr) são os constituintes do grupo 1A da tabela periódica, denominados de metais alcalinos ou álcalis. Somente o sódio e o potássio ocorrem no clínquer Portland em quantidades significativas, sendo que o potássio é mais comum que o sódio (Diamond, 1975).

Os álcalis dos cimentos provêm das matérias-primas utilizadas na fabricação do clínquer Portland e situam-se na faixa de 0,2 a 1,5\% de equivalente alcalino em $\mathrm{Na}_{2} \mathrm{O}\left(\% \mathrm{Na}_{2} \mathrm{O}+0,658 \% \mathrm{~K}_{2} \mathrm{O}\right)($ Taylor, 1997).

Durante o processo de clinquerização, os álcalis provenientes das matérias-primas calcário e argila e o enxofre oxidado dos combustíveis volatilizam-se nas zonas mais quentes do forno e são transportados para as regiões mais frias, juntamente com dióxido de carbono e água. Após a saturação da atmosfera, o anidrido sulfúrico combina-se preferencialmente com os álcalis formando os sulfatos alcalinos, que são depositados nas paredes do forno ou incorporados à estrutura dos cristais do clínquer Portland (Glasser, 1992).

Os álcalis presentes no cimento Portland são expressos na forma de óxido de potássio $\left(\mathrm{K}_{2} \mathrm{O}\right)$ e óxido do sódio $\left(\mathrm{Na}_{2} \mathrm{O}\right)$. A quantidade de álcalis disponíveis no cimento Portland é expressa em equivalente alcalino em $\mathrm{Na}_{2} \mathrm{O}$ por apresentar melhor correlação com a expansão relacionada com a reação álcali-agregado (Diamond, 1975).

Os sulfatos alcalinos arcanita - $\mathrm{K}_{2} \mathrm{SO}_{4}$, langbeinita cálcica $-\mathrm{K}_{2} \mathrm{Ca}_{2}\left(\mathrm{SO}_{4}\right)_{3}$ e aftitalita $\mathrm{K}_{3} \mathrm{Na}\left(\mathrm{SO}_{4}\right)_{2}$ são as principais fontes de álcalis solúveis em água do clínquer Portland. Os álcalis insolúveis estão normalmente presentes em solução sólida nos silicatos de cálcio (alita - $\mathrm{Ca}_{3} \mathrm{SiO}_{5}-\mathrm{C}_{3} \mathrm{~S}$ e belita $-\mathrm{Ca}_{2} \mathrm{SiO}_{4}-\mathrm{C}_{2} \mathrm{~S}$ ) e nos aluminatos de cálcio $\left(\mathrm{Ca}_{3} \mathrm{Al}_{2} \mathrm{O}_{6}-\mathrm{C}_{3} \mathrm{~A}\right.$ e $\left.\mathrm{Ca}_{4} \mathrm{Al}_{2} \mathrm{Fe}_{2} \mathrm{O}_{10}-\mathrm{C}_{4} \mathrm{AF}\right)$. O $\mathrm{C}_{3} \mathrm{~A}$ incorpora principalmente sódio, passando do sistema cúbico para o ortorrômbico (Taylor, 1997). 
A alta solubilidade dos sulfatos alcalinos em água permite que estejam disponíveis na solução quase que imediatamente, enquanto os álcalis insolúveis incorporados à estrutura dos cristais dependem da taxa de hidratação das fases do clínquer Portland para serem disponibilizados. A liberação total dos álcalis varia de um cimento para outro dependendo da sua distribuição entre as fases do clínquer Portland.

Como a reação álcali-agregado ocorre lentamente, é provável que todos os álcalis do cimento, independentemente da fonte, sejam disponibilizados ao longo do tempo. (Diamond, 1975; Glasser, 1992).

A produção de íons hidroxila pelos sulfatos alcalinos, aparentemente, relaciona-se à formação de etringita, a qual consome o íon sulfato da solução. Os íons alcalinos que sobraram na solução são balanceados pelos íons hidroxila fornecidos pelo $\mathrm{Ca}(\mathrm{OH})_{2}$, produzido durante a hidratação do cimento Portland. Como os íons hidroxila são liberados para balancear os íons alcalinos, o cálcio é liberado para a formação de produtos hidratados. Os íons alcalinos e íons hidroxila livres é que vão reagir com as fases reativas dos agregados (Diamond, 1975).

Glasser (1992) relata que as adições ao cimento como escória de alto-forno, cinza volante e sílica ativa também são fontes de álcalis para a solução dos poros do concreto. A disponibilização destes álcalis dependerá do teor adicionado, da forma de ocorrência (solúvel ou insolúvel) e da taxa de hidratação destes materiais.

No caso da escória de alto-forno, os álcalis estão dissolvidos uniformemente no vidro e devem ser considerados como potencialmente disponíveis para a liberação, dependendo da taxa de hidratação da escória, mais lenta que o clínquer.

A cinza volante também contém álcalis. Durante a combustão do carvão, parte dos álcalis é evaporada nas zonas mais quentes do forno e condensam nas regiões mais frias sobre a superfície das partículas de cinza volante, mas podem estar também presentes nas fases cristalinas da cinza volante. A liberação dos álcalis da cinza volante tende a ser mais complexa, pois a fração solúvel é liberada instantaneamente enquanto a fração insolúvel presente na fase vítrea depende da taxa de hidratação, o que pode levar meses ou anos para ocorrer. 
Os álcalis também estão presentes nos minerais constituintes das rochas e podem ser liberados para a solução dos poros através do ataque da solução alcalina sobre as fases reativas. Os feldspatos e as micas são os minerais mais susceptíveis a contribuir com álcalis para a solução dos poros. Se o agregado é potencialmente reativo, mesmo liberando pequenas quantidades de álcalis, tem impacto significativo sobre a durabilidade do concreto, devido ao volume em que é utilizado (Duyou et al., 2006).

Lu et al. (2006), com o objetivo de quantificar a contribuição dos álcalis para a reação álcali-agregado, estudaram três fatores que podem influenciar na liberação para a solução dos poros do concreto: finura, temperatura e tipo de solução. Para tal, utilizaram três agregados litologicamente diferentes: granito, gnaisse e feldspato potássico, sendo que o granito foi empregado na construção da barragem ThreeGorges na China.

Os ensaios foram realizados nos agregados após moagem e peneiramento nas frações $10-12,5-10,1,25-5,0,63-1,25,0,15-0,63$ e 0,08-0,15mm. Após a preparação, $25 \mathrm{~g}$ de cada fração foram colocados em frascos de polietileno com $50 \mathrm{ml}$ de solução saturada de $\mathrm{Ca}(\mathrm{OH})_{2}$ com $1 \mathrm{~g}$ de excesso de sólido, e armazenados em estufa a 20, 40, 60 e $80^{\circ} \mathrm{C}$. Os ensaios para determinação dos teores de $\mathrm{Na}_{2} \mathrm{O}$ e $\mathrm{K}_{2} \mathrm{O}$ por fotometria de chama foram realizados nas idades de 3, 7, 14, 21 e 28 dias. Para efeitos comparativos, os ensaios também foram realizados com água destilada a $80^{\circ} \mathrm{C}$.

A Figura 1 mostra que 0 teor de álcalis liberado aos 28 dias na solução supersaturada de $\mathrm{Ca}(\mathrm{OH})_{2}$ a $80^{\circ} \mathrm{C}$ é quase o dobro do teor liberado na água destilada, para todas as frações do granito e do gnaisse. $O$ feldspato potássico liberou aproximadamente cinco vezes mais álcalis na solução supersaturada de $\mathrm{Ca}(\mathrm{OH})_{2}$ do que na água destilada.

O gnaisse tem o menor teor de álcalis em $\mathrm{Na}_{2} \mathrm{O}_{e}$ entre as amostras analisadas, mas foi a que liberou a maior quantidade para as soluções. O feldspato potássico com o maior teor de álcalis na rocha foi o que liberou menos em água destilada, mas liberou mais em solução saturada de $\mathrm{Ca}(\mathrm{OH})_{2}$, em relação ao gnaisse. 
Os autores comentam que essas diferenças estão relacionadas com a composição mineralógica das rochas e com o estado de alteração metamórfica, principalmente do gnaisse que se encontra alterado por processos metamórficos.

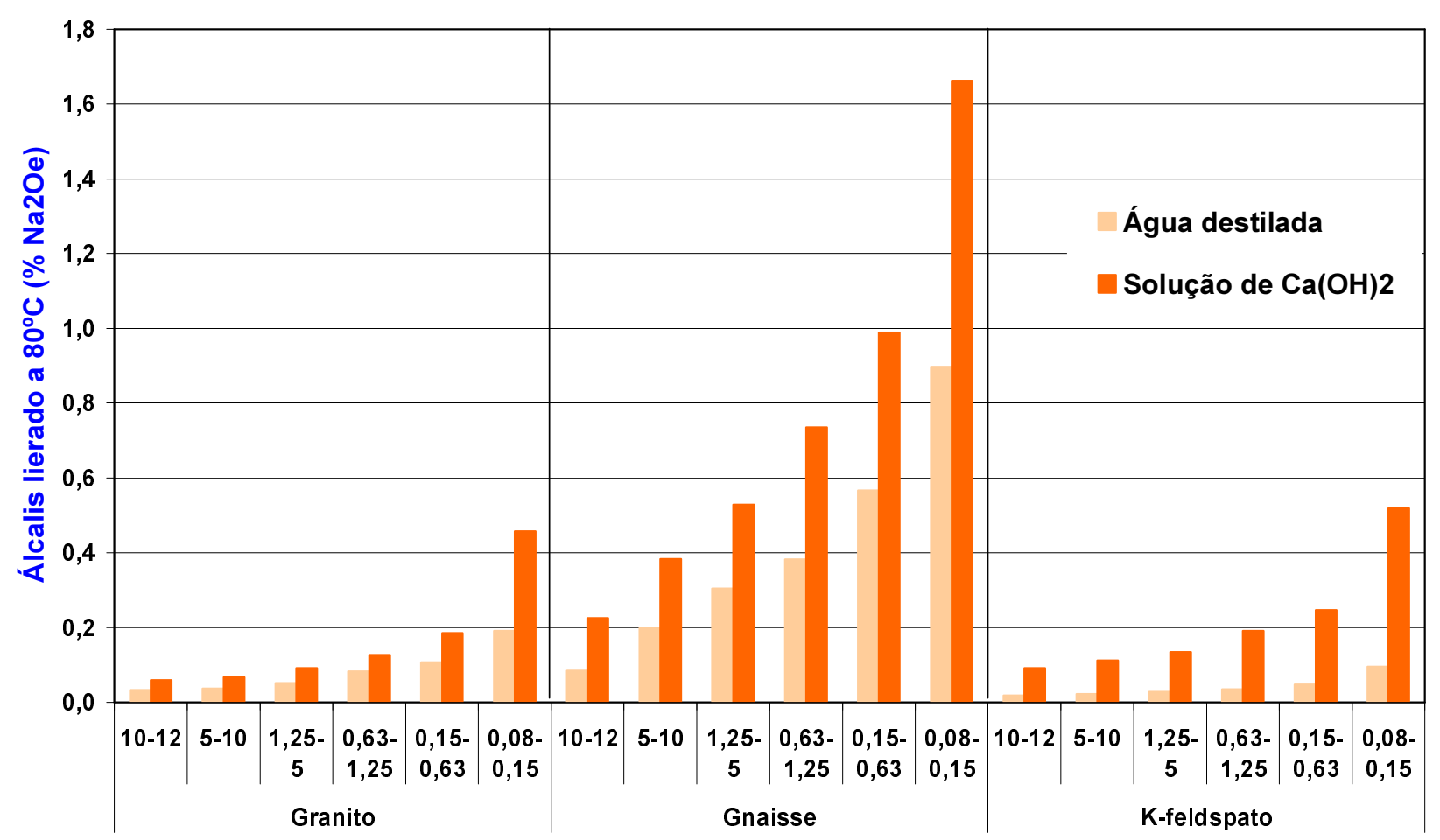

Frações $(\mathrm{mm})$ e tipo de agregado

Figura 1 - Liberação de álcalis dos agregados em solução supersaturada de $\mathrm{Ca}(\mathrm{OH})_{2}$ e em água destilada a $80^{\circ} \mathrm{C}$ aos 28 dias em diversas frações (Duyou et al., 2006)

Os autores concluíram que os álcalis são liberados tanto em água destilada quanto em solução saturada de $\mathrm{Ca}(\mathrm{OH})_{2}$, sendo que a taxa de liberação aumenta com a temperatura e a redução do diâmetro das partículas, e é mais significativa na solução de $\mathrm{Ca}(\mathrm{OH})_{2}$ do que em água destilada. $\mathrm{O}$ gnaisse que contém minerais alterados de feldspato e mica liberou mais álcalis do que o granito e o feldspato potássico. Os autores mencionam que deve ser considerada a liberação de álcalis quando da utilização de agregados potencialmente reativos em estruturas de concreto massa.

Zampieri, Kihara e Scandiuzzi (1992), analisando amostras de concreto da Barragem de Pedras (BA), concluíram que, além do quartzo deformado com extinção ondulante, o feldspato alcalino deformado também contribuiu para a reação álcali-silicato e forneceu parte dos álcalis necessária à reação. Esses minerais intensamente deformados e cisalhados foram os responsáveis pela reação álcalisilicato, de natureza mais lenta e complexa que os outros tipos de reação. 
Diamond (1989) demonstrou, a partir da compilação de vários trabalhos, que há uma relação linear entre o teor total de álcalis $\left(\% \mathrm{Na}_{2} \mathrm{O}_{\mathrm{e}}\right)$ e a concentração de íons hidroxila na solução dos poros de pastas e argamassas preparadas com cimentos sem adições ativas e com relação água:cimento de 0,50. Para atingir o equilíbrio dos íons hidroxila, os ensaios foram realizados nas pastas e argamassas com pelo menos 30 dias de cura; outros pesquisadores realizaram os ensaios após vários anos. A Figura 2 apresenta os dados compilados em sete trabalhos totalizando 19 cimentos diferentes com $\% \mathrm{Na}_{2} \mathrm{O}_{e}$ variando de 0,31 a 1,31.

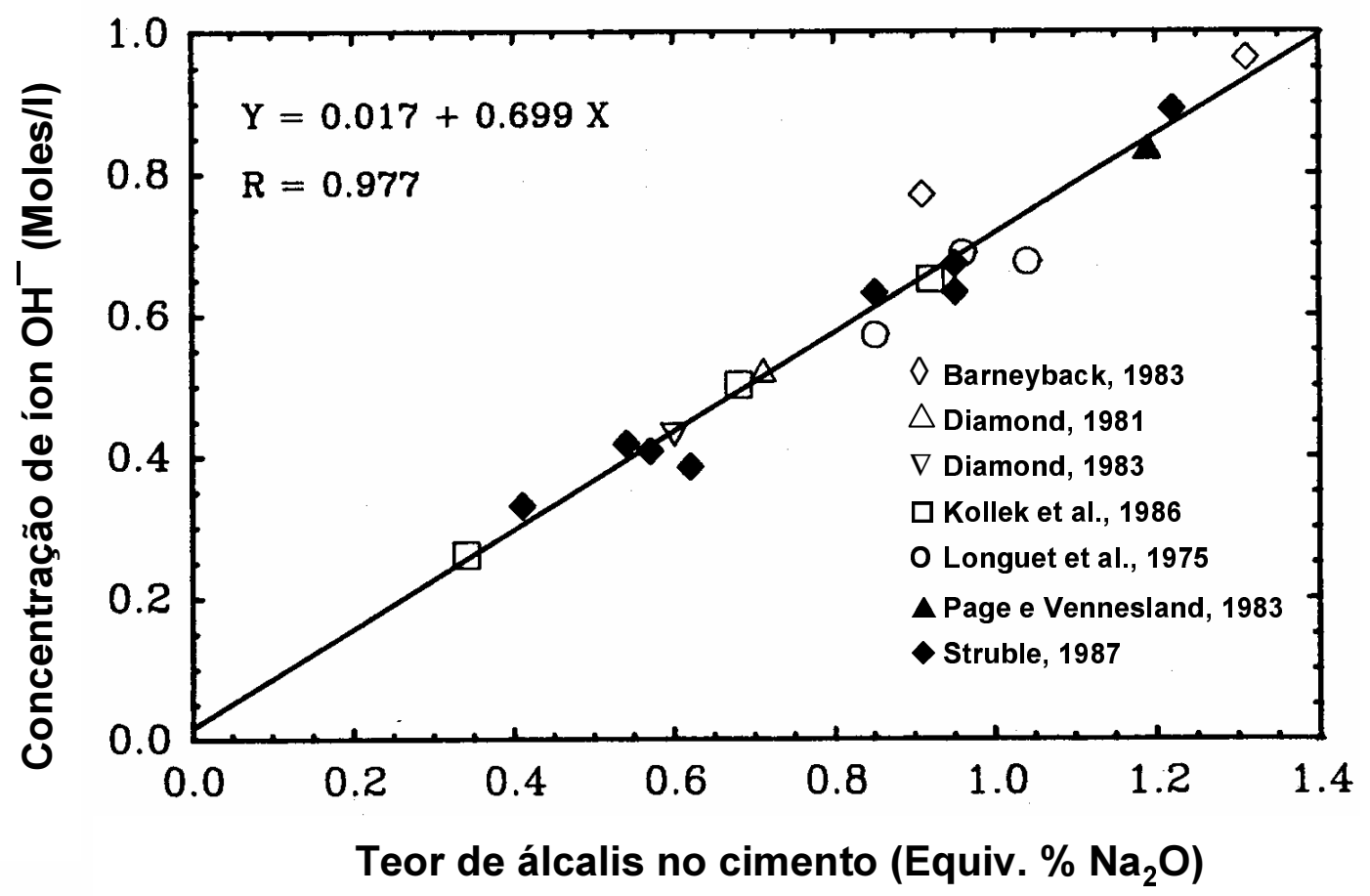

Figura 2 - Relação entre a concentração de íons $\mathrm{OH}^{-}$em equilíbrio na solução dos poros e teor de álcalis $\left(\% \mathrm{Na}_{2} \mathrm{O}_{e}\right)$ no cimento. Ensaios realizados em pastas e argamassas com relação água:cimento 0,50 (Diamond, 1989).

Soluções saturadas de hidróxido de cálcio apresentam pH máximo de 12,4, mas no concreto, o pH pode atingir valores de 12,5 a 13,5 devido à contribuição dos íons alcalinos, que podem atuar aumentando o nível de íons hidroxila acima do nível normal, favorecendo a dissolução da sílica reativa presente am alguns agregados (Prezzi, 1997). Diamond (1975) menciona que os álcalis aumentam a concentração de íons hidroxila na solução dos poros em mais de dezessete vezes comparada à solução saturada de hidróxido de cálcio puro. 
A ASTM C 150 (2005) classifica cimentos de baixo teor de álcalis aqueles com menos de 0,60\% de equivalente alcalino, expresso em $\mathrm{Na}_{2} \mathrm{O}$. Esse limite é recomendado em várias especificações para minimizar os riscos de deterioração do concreto quando são utilizados agregados reativos. Entretanto, há vários registros de ocorrência de RAA quando se utilizaram cimentos com $\mathrm{Na}_{2} \mathrm{O}_{e}$ menor que $0,60 \%$ (ACl221.1R-98, 1998).

Fournier e Bérubé (2000) mencionam que a RAA no concreto pode ser reduzida, ou mesmo prevenida, utilizando-se cimentos de baixo teor de álcalis ou limitando o teor total de álcalis por $\mathrm{m}^{3}$ de concreto. O limite normalmente recomendado é de $3 \mathrm{~kg} / \mathrm{m}^{3}$ $\mathrm{Na}_{2} \mathrm{O}_{e}$ no concreto. Citam que esse "limite seguro" pode variar de acordo com o nível de reatividade do agregado e pode estar na faixa de 1,8 a $3,0 \mathrm{~kg} / \mathrm{m}^{3}$, dependendo do grau de reatividade do agregado, das condições de exposição da estrutura e da vida útil.

A Tabela 3 apresenta o teor de álcalis fornecido pelo cimento ao concreto em função da dosagem de cimento e do teor de álcalis do cimento $\left(\% \mathrm{Na}_{2} \mathrm{O}_{e}\right)$.

Tabela 3 - Teor de álcalis $\left(\mathrm{kg} / \mathrm{m}^{3} \mathrm{Na}_{2} \mathrm{O}_{\mathrm{e}}\right)$ fornecido pelo cimento ao concreto em função da dosagem de cimento $\left(\mathrm{kg} / \mathrm{m}^{3}\right)$ e do teor de álcalis do cimento $\left(\% \mathrm{Na}_{2} \mathrm{O}_{\mathrm{e}}\right)$

\begin{tabular}{|c|c|c|c|c|c|}
\hline \multirow{3}{*}{$\begin{array}{l}\text { Teor de } \\
\text { cimento } \\
\left(\mathrm{kg} / \mathrm{m}^{3}\right)\end{array}$} & \multicolumn{5}{|c|}{ Teor de álcalis no cimento $\left(\% \mathrm{Na}_{2} \mathrm{O}_{\mathrm{e}}\right)$} \\
\hline & 0,6 & 0,7 & 0,8 & 0,9 & 1,0 \\
\hline & \multicolumn{5}{|c|}{ Álcalis fornecidos pelo cimento $\left(\mathrm{kg} / \mathrm{m}^{3} \mathrm{Na}_{2} \mathrm{O}_{\mathrm{e}}\right)$} \\
\hline 250 & 1,50 & 1,75 & 2,00 & 2,25 & 2,50 \\
\hline 275 & 1,65 & 1,93 & 2,20 & 2,48 & 2,75 \\
\hline 300 & 1,80 & 2,10 & 2,40 & 2,70 & 3,00 \\
\hline 325 & 1,95 & 2,28 & 2,60 & 2,93 & 3,25 \\
\hline 350 & 2,10 & 2,45 & 2,80 & 3,15 & 3,50 \\
\hline 375 & 2,25 & 2,63 & 3,00 & 3,38 & 3,75 \\
\hline 400 & 2,40 & 2,80 & 3,20 & 3,60 & 4,00 \\
\hline 425 & 2,55 & 2,98 & 3,40 & 3,83 & 4,25 \\
\hline
\end{tabular}


Olberholster, Van Aardt e Brandt, 1983 apud Hasparyk, 1999 estabeleceram os seguintes limites para os agregados sul africanos:

$>$ acima de $3,8 \mathrm{~kg} / \mathrm{m}^{3}$ de $\mathrm{Na}_{2} \mathrm{O}_{\mathrm{e}}$, comportamento expansivo;

$>$ entre $1,8 \mathrm{~kg} / \mathrm{m}^{3}$ e $3,8 \mathrm{~kg} / \mathrm{m}^{3}$ de $\mathrm{Na}_{2} \mathrm{O}_{\mathrm{e}}$, comportamento potencialmente reativo;

> abaixo de $1,8 \mathrm{~kg} / \mathrm{m}^{3}$ de $\mathrm{Na}_{2} \mathrm{O}_{\mathrm{e}}$, comportamento inócuo.

A Figura 3 ilustra graficamente os limites propostos considerando-se os álcalis disponíveis no cimento e o consumo de cimento no concreto.

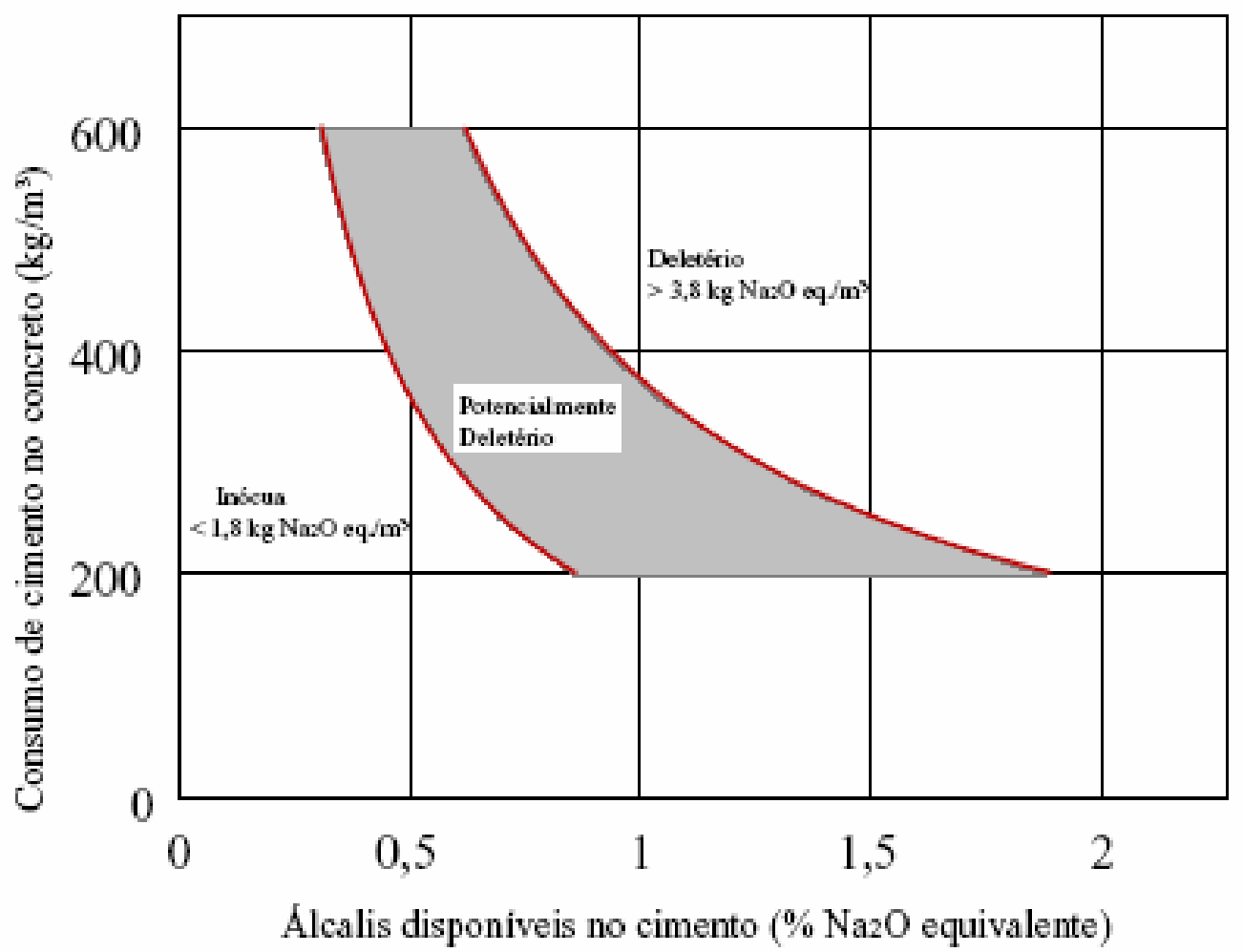

Figura 3- Classificação do comportamento da reação em função da relação entre os álcalis disponíveis e o consumo de cimento no concreto (Oberholster, Van Aardt \& Brandt, 1983 apud Hasparyk, 1999) 


\subsubsection{Umidade}

A água é o agente principal de deterioração física e química do concreto, pois além de ter grande facilidade em se mover através dos poros do concreto, devido ao tamanho de suas moléculas, é um excelente solvente, com capacidade de dissolver muitas espécies químicas, tornando-a rica em íons e gases capazes de causar a deterioração (Mehta e Monteiro,1994).

A maior ou menor facilidade com que os fluidos podem ingressar e se deslocar no interior do concreto depende de sua permeabilidade, a qual está relacionada ao volume, tamanho, distribuição e continuidade dos poros da pasta de cimento endurecida (Neville, 1997).

A permeabilidade, por sua vez, depende da relação água:cimento e da compacidade do concreto. À medida que a relação água/cimento diminui, o concreto torna-se mais resistente, impermeável e com menores teores de água livre interna. Esses fatores são imprescindíveis para reduzir a velocidade de penetração de agentes agressivos e a movimentação da umidade interna no concreto (Mehta e Monteiro,1994; Neville, 1997).

A baixa relação água/cimento acarretará, no entanto, maior concentração de íons alcalinos na solução dos poros e menor porosidade. Quanto menos espaços vazios o concreto apresentar, menor será a acomodação das tensões internas geradas pela RAA e maior será o processo de fissuração.

Outra maneira de reduzir a permeabilidade é através da utilização das adições ativas, que confere um refinamento do tamanho do poro pelo preenchimento dos espaços capilares maiores que $0,1 \mu \mathrm{m}$. Os vazios capilares com tamanho superior a $0,05 \mu \mathrm{m}$, denominados macroporos, aumentam a permeabilidade da pasta de cimento e reduzem as resistências, enquanto os microporos com tamanho inferior a $0,05 \mu \mathrm{m}$, contribuem para maior durabilidade do concreto (Mehta e Monteiro,1994). 
Os concretos de cimento Portland normalmente são preparados com relação água:cimento entre 0,35 e 0,55. Entretanto, a quantidade de água requerida para toda a hidratação é de aproximadamente 0,24 , conseqüentemente há um excesso de água no concreto que o manterá com umidade relativa interna alta, favorecendo a ocorrência de RAA (Glasser, 1992).

A água desempenha duas funções na reação álcali-agregado. Primeiro, é essencial para transportar o íon hidroxila e os cátions alcalinos; segundo, é absorvida em grandes quantidades pelo produto da reação álcali-agregado denominado de gel de silicato alcalino, que expande, gerando pressão hidráulica na pasta de cimento suficiente para causar fissuramento (Poole, 1992).

Para o desenvolvimento da reação álcali-agregado, a umidade relativa interna do concreto deve ser superior a aproximadamente 80\% (BCA, 1992 apud Furnier \& Bérebé, 2000; $\mathrm{ACl} 221.1 \mathrm{R}, 2005)$. No entanto, essa umidade varia em função da umidade relativa do ambiente no qual a estrutura está inserida. Em estruturas de concreto maciças, a umidade interna é menos sensível a ciclos de molhagem e secagem do que as não-maciças e podem desenvolver a RAA mesmo quando submetidas a condições de umidade relativa do ambiente baixa, porque a umidade interna do concreto mantém as condições necessárias ao desenvolvimento da reação (Stark \& Depuy, 1987 apud Furnier \& Bérebé, 2000).

Manter o concreto seco reduz o potencial de expansão do gel, mas, na prática, isso somente é possível em estruturas de concreto que não estão em contato direto com a água, como por exemplo, no interior das edificações. Estruturas de concreto em contato direto com a água ou sujeitas a ciclos de molhagem e secagem são as mais susceptíveis a desenvolver RAA (ACI 221.1R, 1998).

Estudos-de-caso e investigações laboratoriais demonstraram que a expansão varia diretamente com a umidade relativa do concreto. Quando a umidade relativa é inferior a $70 \%$, a expansão é relativamente baixa, enquanto que acima de $80 \%$, aumenta exponencialmente, conforme demonstrado na Figura 4 (Poole, 1992). 


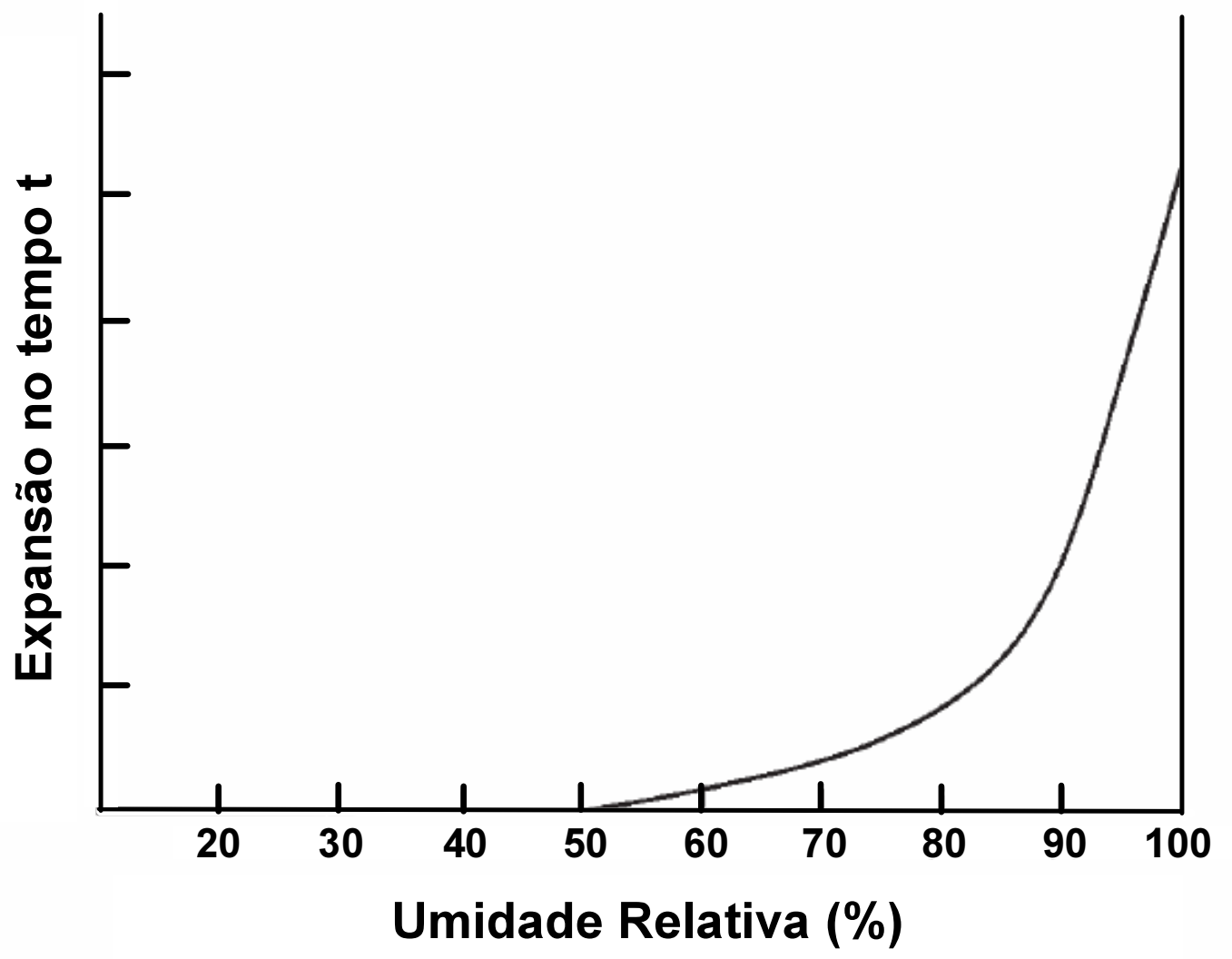

Figura 4 - Efeito da umidade relativa na expansão do concreto devido à reação álcaliagregado (Poole, 1992). 


\subsection{Química da Reação Álcali-Agregado}

Os termos reação álcali-agregado (RAA) e reação álcali-sílica (RAS) são universalmente usados e aceitos. Entretanto, induzem a uma interpretação errônea do processo químico envolvido na reação, pois as fases reativas presentes nos agregados são atacadas pelos íons hidroxila $\left(\mathrm{OH}^{-}\right)$dissolvidos na solução dos poros do concreto, cujo produto da reação incorpora os cátions alcalinos presentes formando gel de silicatos alcalinos.

A RAA depende muito mais da concentração de íons hidroxila na solução dos poros do que dos cátions alcalinos. Entretanto, a concentração de íons hidroxila é fortemente influenciada pela concentração de íons alcalinos (Diamond, 1975, Diamond, 1989).

Os álcalis contribuem para a basicidade $(\mathrm{pH} \geq 12,4)$ da solução dos poros, constituídas principalmente por hidróxidos alcalinos dissolvidos $\left(\mathrm{K}^{+}, \mathrm{Na}^{+}, \mathrm{OH}^{-}\right)$e, em menores quantidades, por outros elementos $\left(\mathrm{Ca}^{2+}, \mathrm{SO}_{4}^{-2}\right)$ (Glasser, 1992).

A RAA não ocorre em minerais com fases silicosas bem cristalizadas e relativamente densas, mas com as fases silicosas, microcristalinas, criptocristalinas e amorfas devido à maior área de contato e à estrutura cristalina aberta e desordenada. Quartzo e feldspato deformados também são reativos com os hidróxidos alcalinos devido à desordem na estrutura cristalina causada por esforços tectônicos. (Glasser, 1992).

A Figura 5 ilustra o arranjo atômico de minerais do grupo da sílica com estrutura ordenada e bem cristalizada que não são atacados pelos íons hidroxila, enquanto minerais com estrutura desordenada e mal cristalizados (quartzo tensionado ou microcristalino, caldedônia, clorofeíta, vidro vulcânico e outras fases amorfas, etc.) são susceptíveis aos ataques pelos íons $\mathrm{OH}^{-}$. 


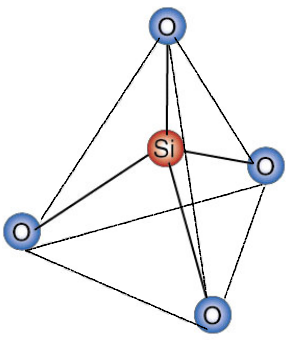

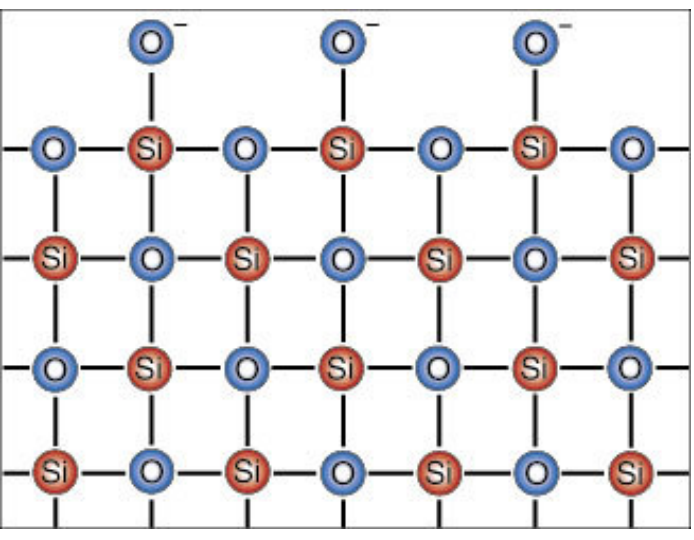

Estrutura ordenada e bem cristalizada

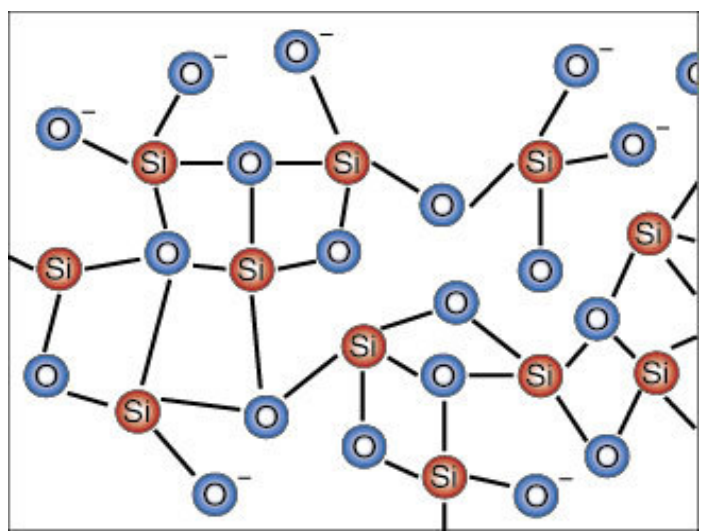

Estrutura desordenada e mal cristalizada

Figura 5 - Arranjo atômico de minerais do grupo da sílica com estrutura ordenada e bem cristalizados, e com estrutura desordenada e mal cristalizados (Collins, 2007)

No concreto os agregados com fases reativas são envolvidos pela pasta de cimento Portland e estão em contato direto com os produtos hidratados e com a solução dos poros, rica em íons dissolvidos, conforme ilustrado na Figura 6.

A reação química entre os íons hidroxila e as fases reativas dos agregados é essencialmente de dissolução, isto é, solubilização da sílica em meio fortemente alcalino (pH alto).

Glasser e Kataoka (1981) descrevem que os íons hidroxila $\left(\mathrm{OH}^{-}\right)$ao penetrarem no agregado com fases reativas atacam as ligações Si-O-Si rompendo a sua estrutura. Das quatro ligações que o silício faz normalmente com oxigênio, uma será ocupada pelo íon $\mathrm{OH}^{-}$. A despolimerização da sílica e formação de silanol (Si-OH) é ilustrada na Figura 7 e pode ser expressa pela seguinte equação:

$$
\mathrm{Si}-\mathrm{O}-\mathrm{Si}+\mathrm{H}_{2} \mathrm{O} \rightarrow \mathrm{Si}-\mathrm{OH}----\mathrm{OH}-\mathrm{Si}
$$


Com o prosseguimento da reação, grupos de silanol (Si-OH) são rompidos pelos íons $\mathrm{OH}^{-}$em íons $\mathrm{SiO}^{-}$, sobre a superfície do agregado, conforme ilustrado na Figura 8 e expressa pela seguinte equação:

$$
\mathrm{Si}-\mathrm{OH}+\mathrm{OH}^{-} \rightarrow \mathrm{SiO}^{-}+\mathrm{H}_{2} \mathrm{O}
$$

As cargas negativas criadas pelo rompimento das ligações são balanceadas pelos íons alcalinos com cargas positivas $\left(\mathrm{Na}^{+}, \mathrm{K}^{+}\right)$. Os íons $\mathrm{SiO}^{-}$liberados são atraídos pelos cátions alcalinos da solução dos poros, formando um gel de silicato alcalino em torno do agregado, conforme ilustrado na Figura 9 e expressa pela seguinte equação:

$$
\mathrm{Si}-\mathrm{OH}+\mathrm{Na}^{+}+\mathrm{OH}^{-} \rightarrow \mathrm{Si}-\mathrm{O}-\mathrm{Na}+\mathrm{H}_{2} \mathrm{O}
$$

A composição química do gel é variável e indefinida, pois depende da concentração dos reagentes, da composição da solução dos poros, da temperatura da reação e da fase reativa presente no agregado (Poole, 1992).

A representação estequiométrica aproximada do produto da reação é dada pela seguinte equação (Glasser, 1992):

$$
\mathrm{H}_{0,38} \mathrm{SiO}_{2,19}+0,38 \mathrm{Na}_{2} \mathrm{O} \rightarrow \mathrm{Na}_{0,38} \mathrm{SiO}_{2,19}+0,38 \mathrm{H}_{2} \mathrm{O}
$$

O gel ao absorver água expande e pode exercer pressão osmótica superior à resistência à tração do concreto, causando destruição completa da estrutura, devido às fissurações, perda do módulo de elasticidade e eventualmente da resistência, conforme ilustrado na Figura 10 (Kihara, 1997).

A viscosidade do gel também varia significativamente, pois o produto da reação apresenta alta viscosidade, mas à medida que absorve água torna-se menos viscoso e às vezes fluido suficiente para se movimentar no interior do concreto preenchendo os espaços vazios (Poole, 1992). 


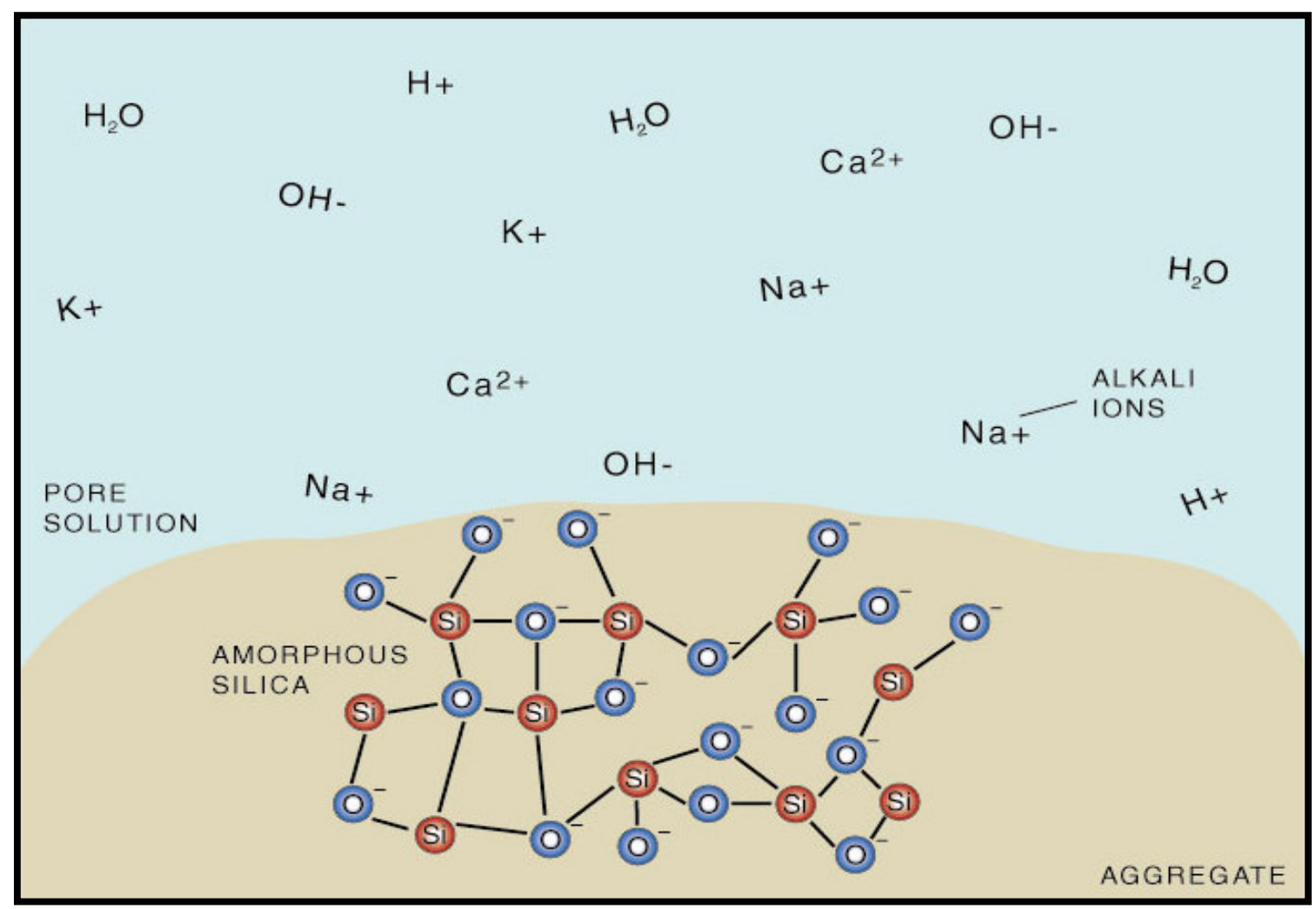

Figura 6 - Grão de agregado em contato com a solução dos poros com fase reativa devido à estrutura cristalina desordenada (Collins, 2007)

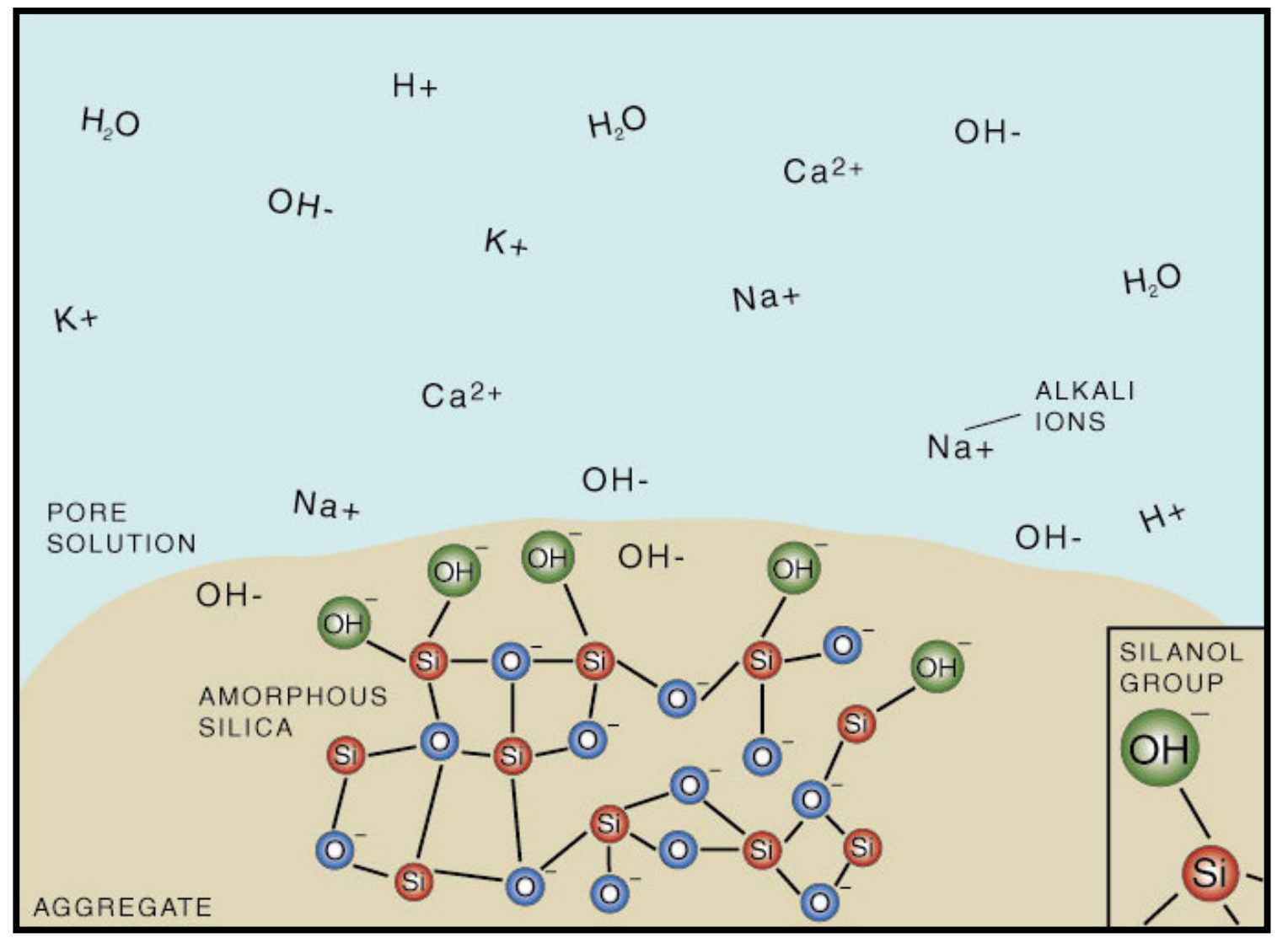

Figura 7 - A superfície do agregado é atacada pelos íons $\mathrm{OH}^{-}$que rompe a ligação Si-O-Si para formar grupos de silanol (Collins, 2007) 


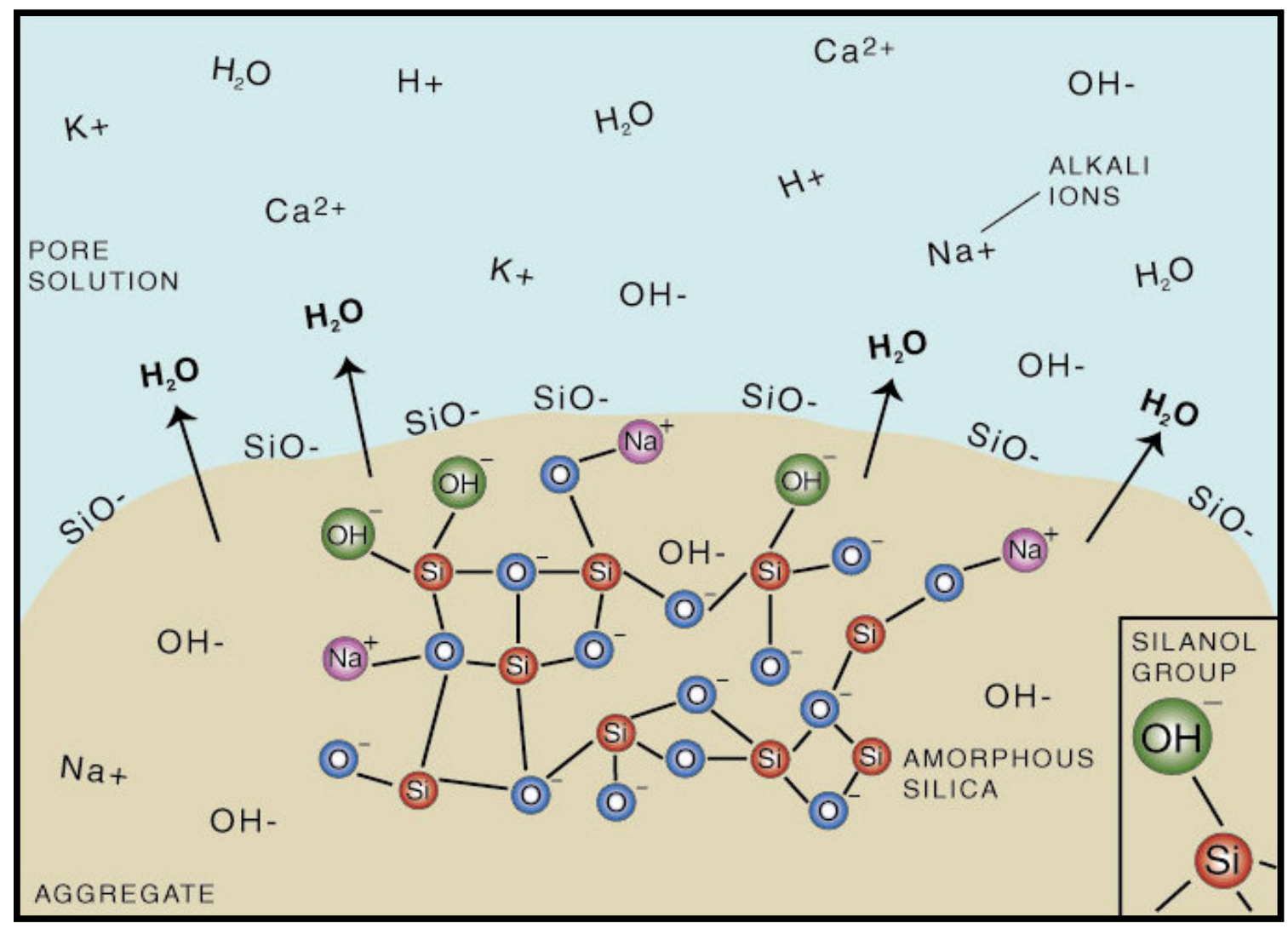

Figura 8 - Grupos de silanol ( $\mathrm{Si}-\mathrm{OH})$ são rompidos pelos íons $\mathrm{OH}^{-}$em íons de $\mathrm{SiO}^{-}$, sobre a superfície do agregado (Collins, 2007)

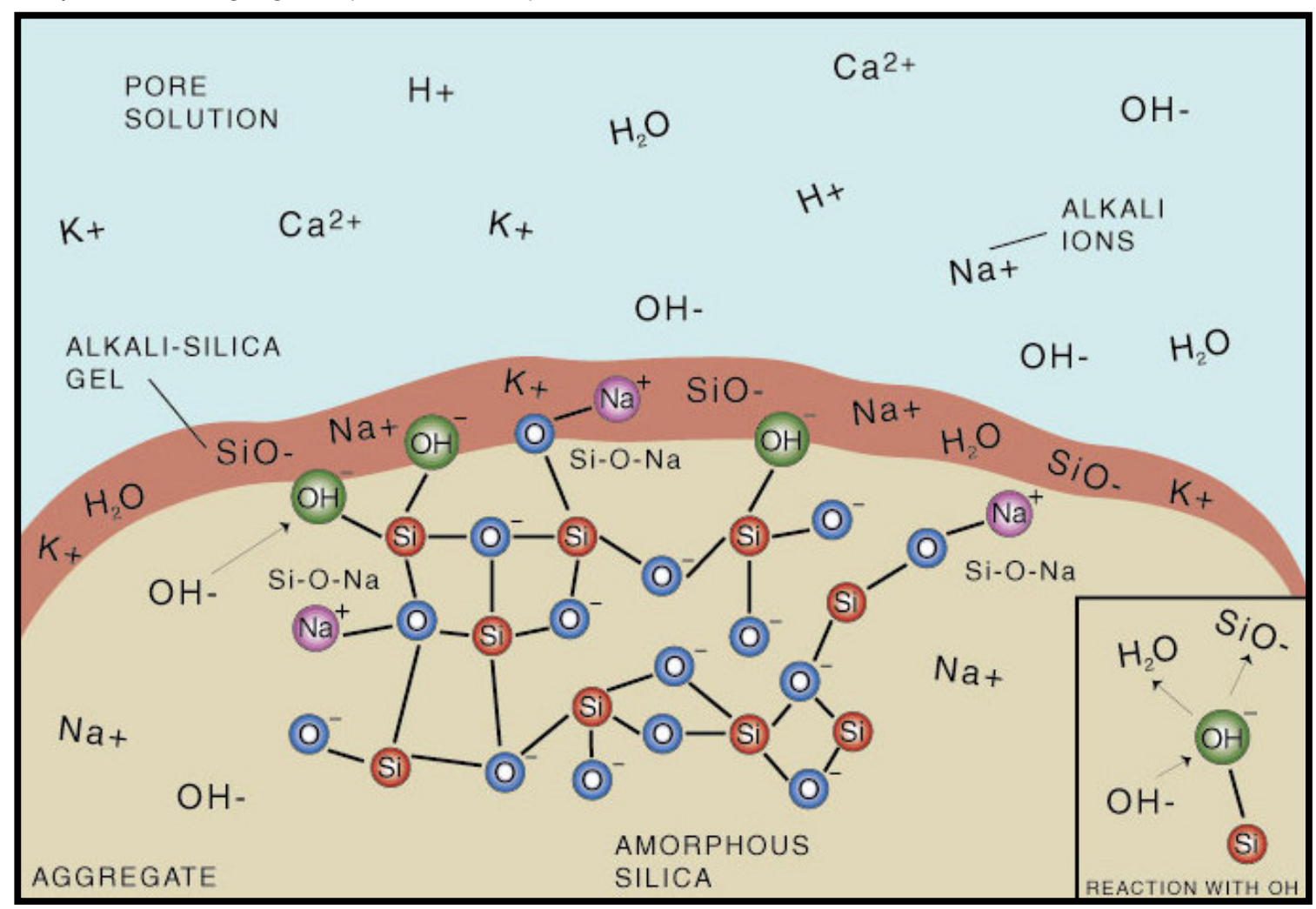

Figura 9 - Os íons de SiO liberados são atraídos pelos cátions alcalinos da solução dos poros, formando gel de silicato alcalino em torno do agregado.

$\mathrm{Si}-\mathrm{OH}+\mathrm{Na}^{+}+\mathrm{OH}^{-} \rightarrow \mathrm{Si}-\mathrm{O}-\mathrm{Na}+\mathrm{H}_{2} \mathrm{O}$ (Collins, 2007) 


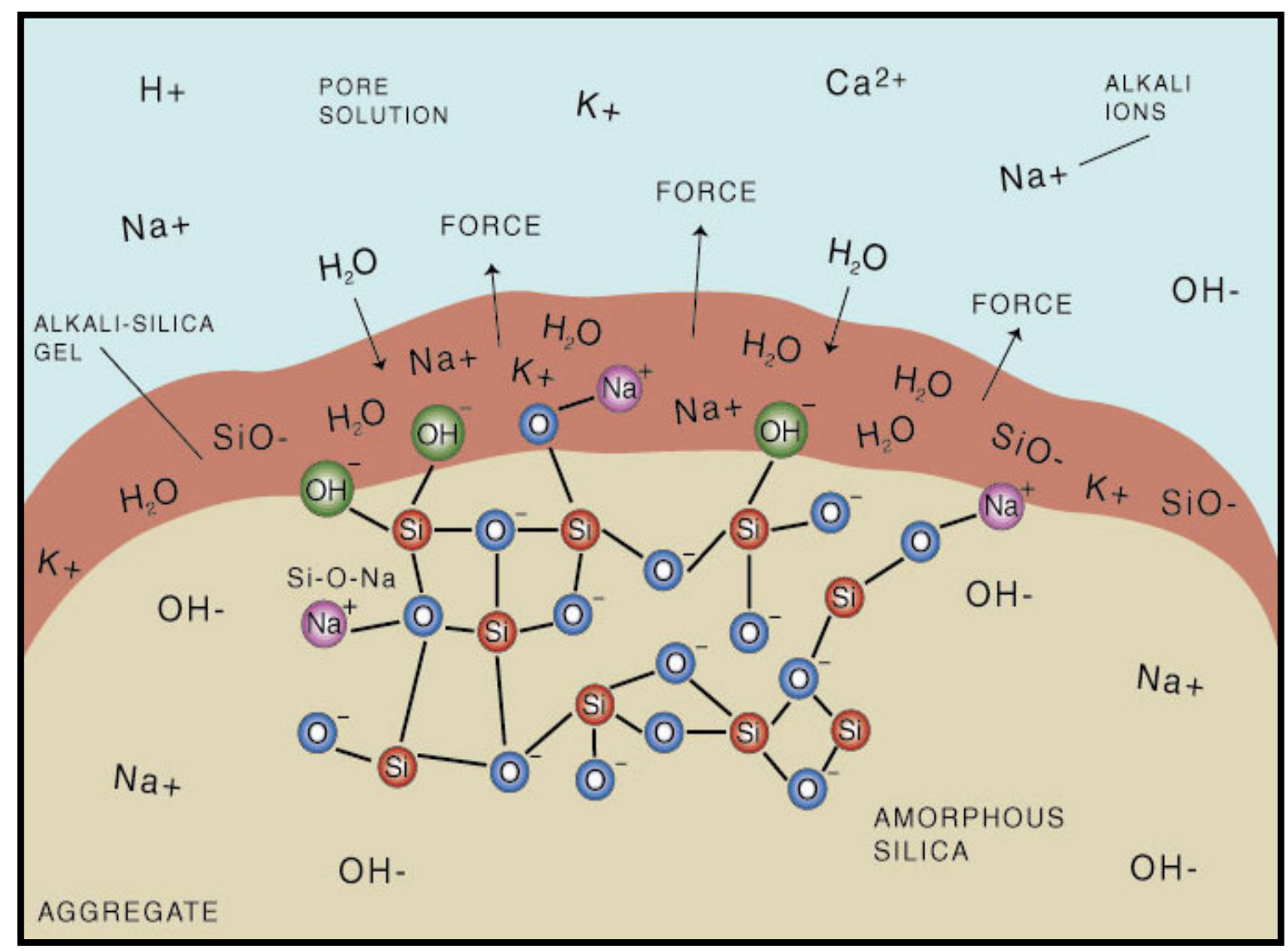

Figura 10 - O gel alcalino, ao absorver água, expande, exercendo pressão osmótica sobre a pasta de cimento ou agregado (Collins, 2007)

A Foto 5 ilustra uma estrutura de concreto com um quadro de fissuras típico de reação álcali-agregado. A Foto 6 ilustra um corpo-de-prova extraído de estrutura de concreto com problemas de reação álcali-agregado. Observa-se que os grãos de agregado graúdo apresentam borda de reação. A Foto 7 mostra borda de reação ao redor do agregado graúdo ao microscópio estereoscópico. A Foto 8 ilustra a deposição de gel no contorno do agregado graúdo ao microscópio de luz transmitida. A Foto 9 mostra poro parcialmente preenchido por material esbranquiçado (gel) ao microscópio estereoscópico. A Foto 10 ilustra gel gretado proveniente da reação álcali-silicato observado ao microscópio eletrônico de varredura. 


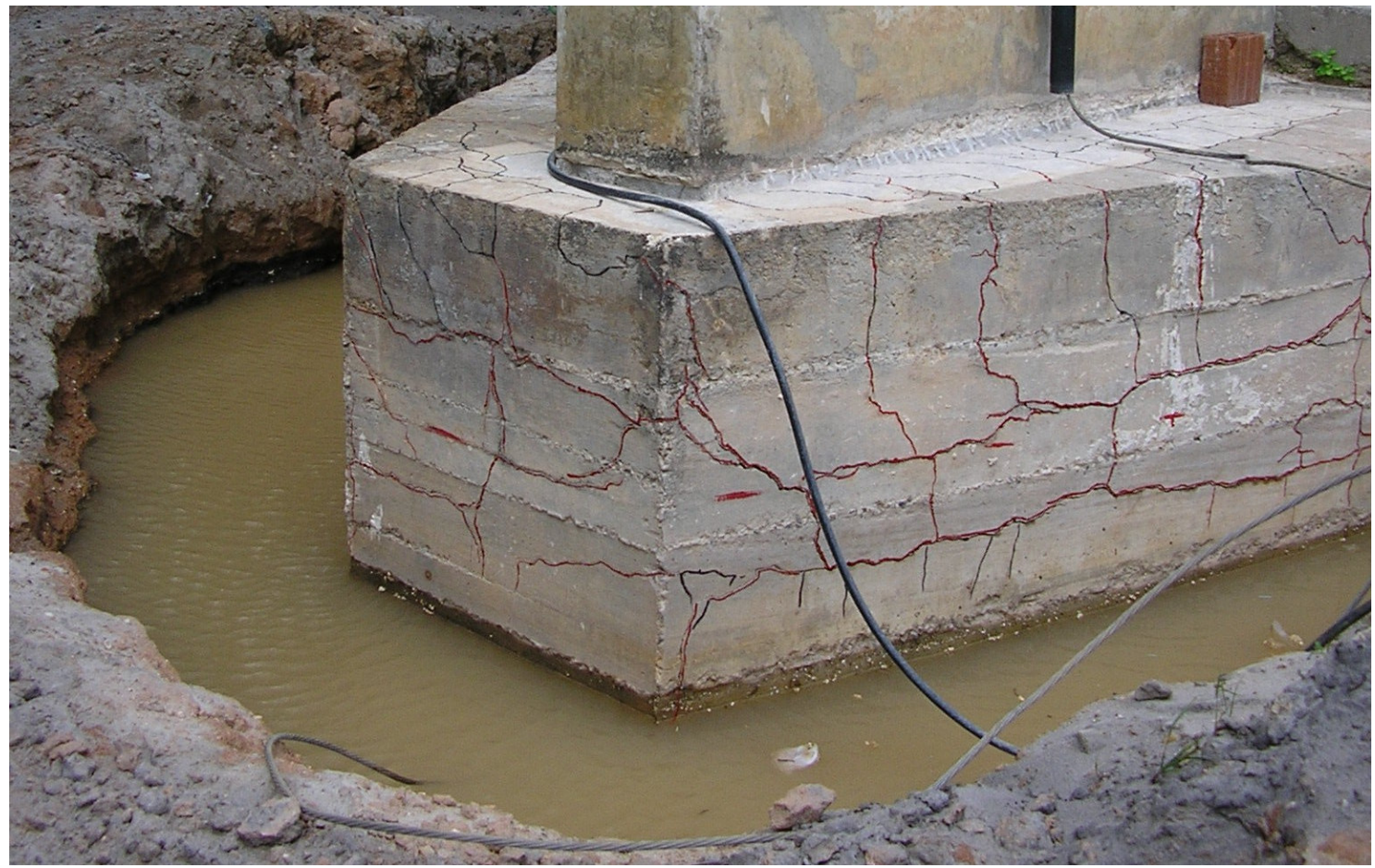

Foto 5 - Bloco de fundação com quadro fissuratório típico de RAA (Acervo ABCP).

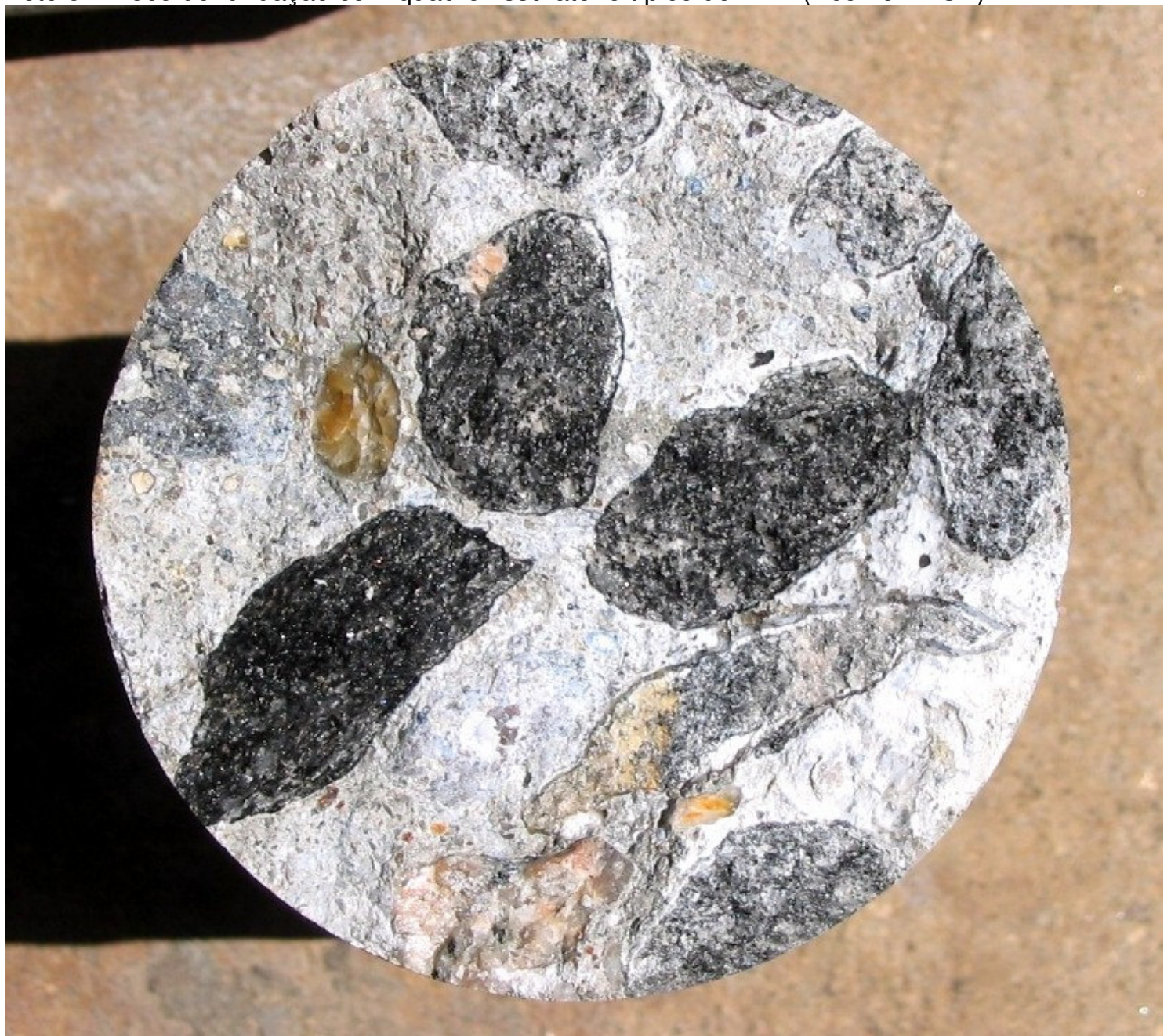

Foto 6 - Agregados graúdos com RAA na interface agregado/matriz de cimento (Pecchio et al., 2006). 


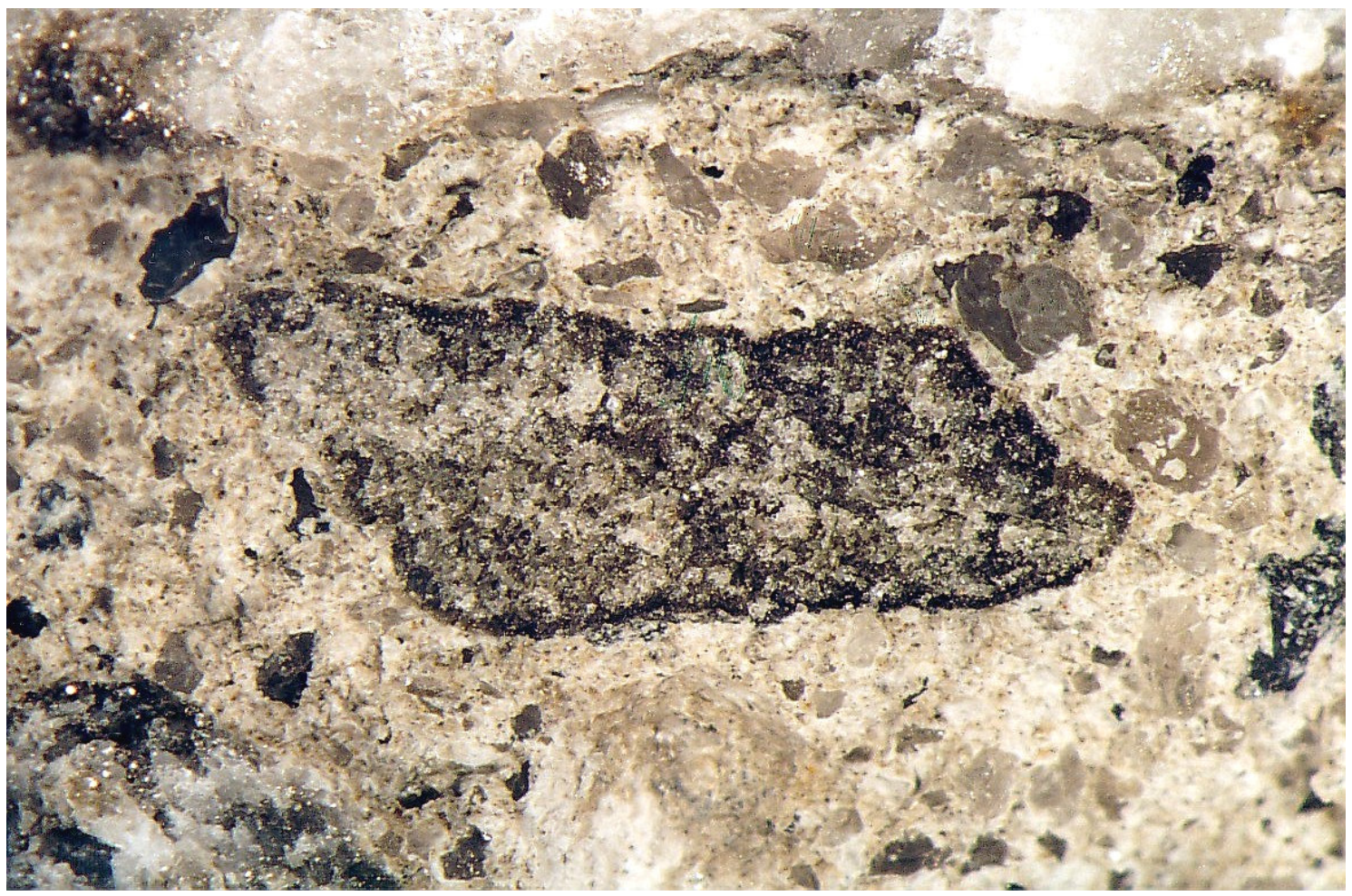

Foto 7 - Aspecto do concreto no qual se observa a formação de borda de reação ao redor do agregado graúdo. Microscópio estereoscópico. Ampliação 9x (Acervo ABCP).

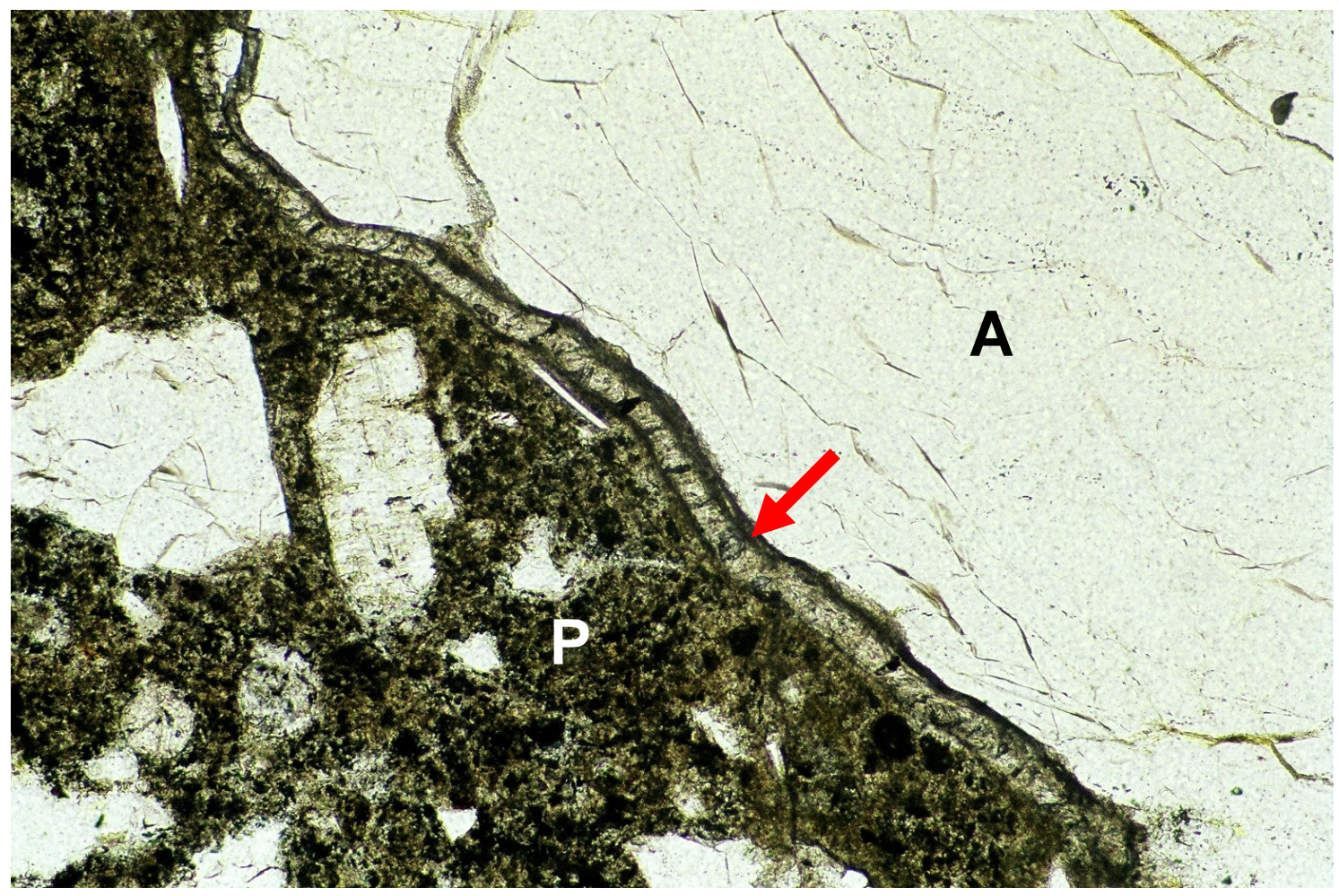

Foto 8 - Aspecto do concreto no qual se observa a deposição de gel (seta) no contorno do agregado graúdo $(\mathrm{A})$. ( $\mathrm{P}=$ Pasta) Microscópio de luz transmitida. Ampliação 100x (Acervo ABCP). 


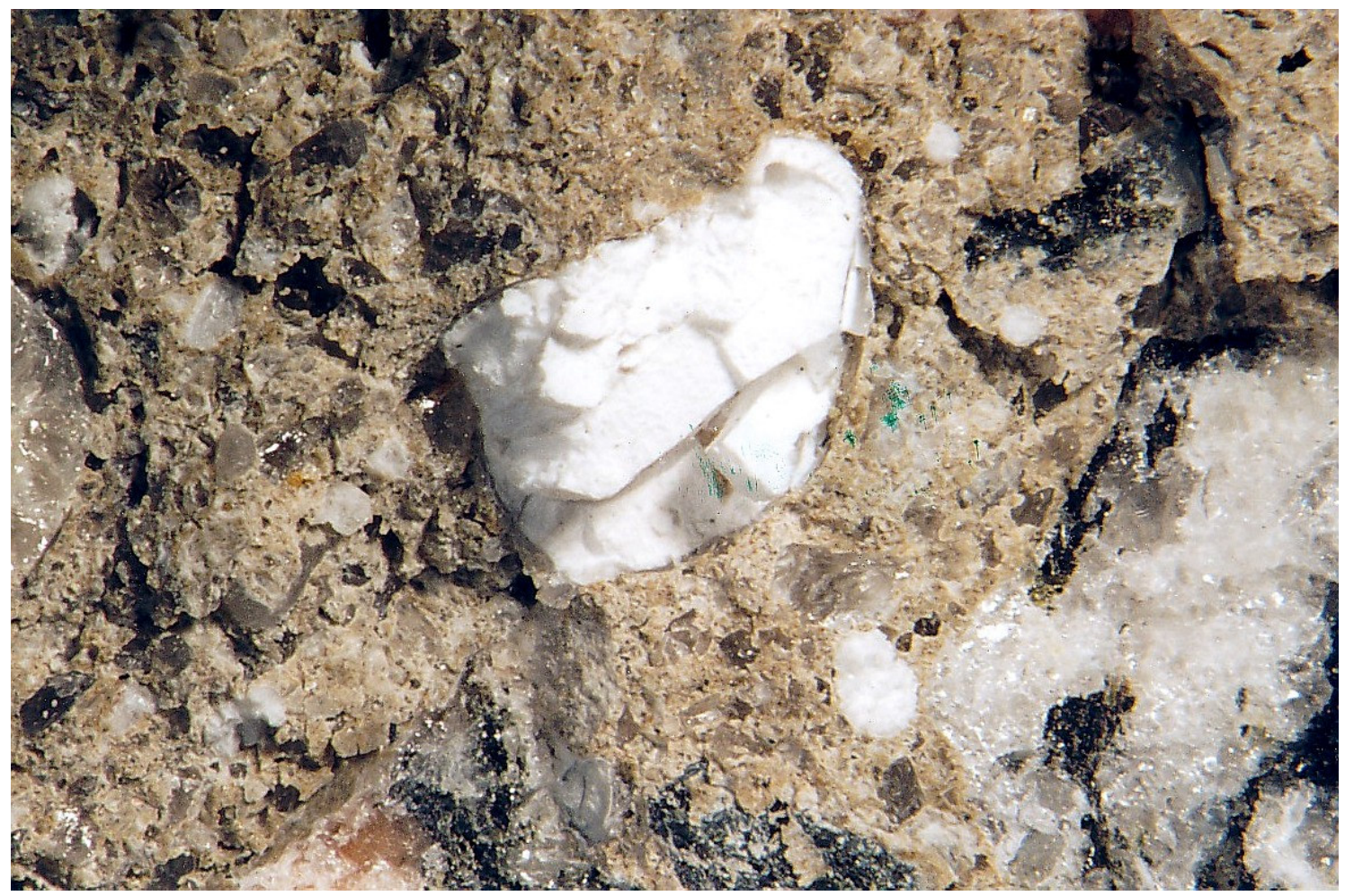

Foto 9 - Detalhe de concreto no qual se observa poro parcialmente preenchido por material esbranquiçado (gel). Microscópio estereoscópico. Ampliação 6x (Acervo ABCP).

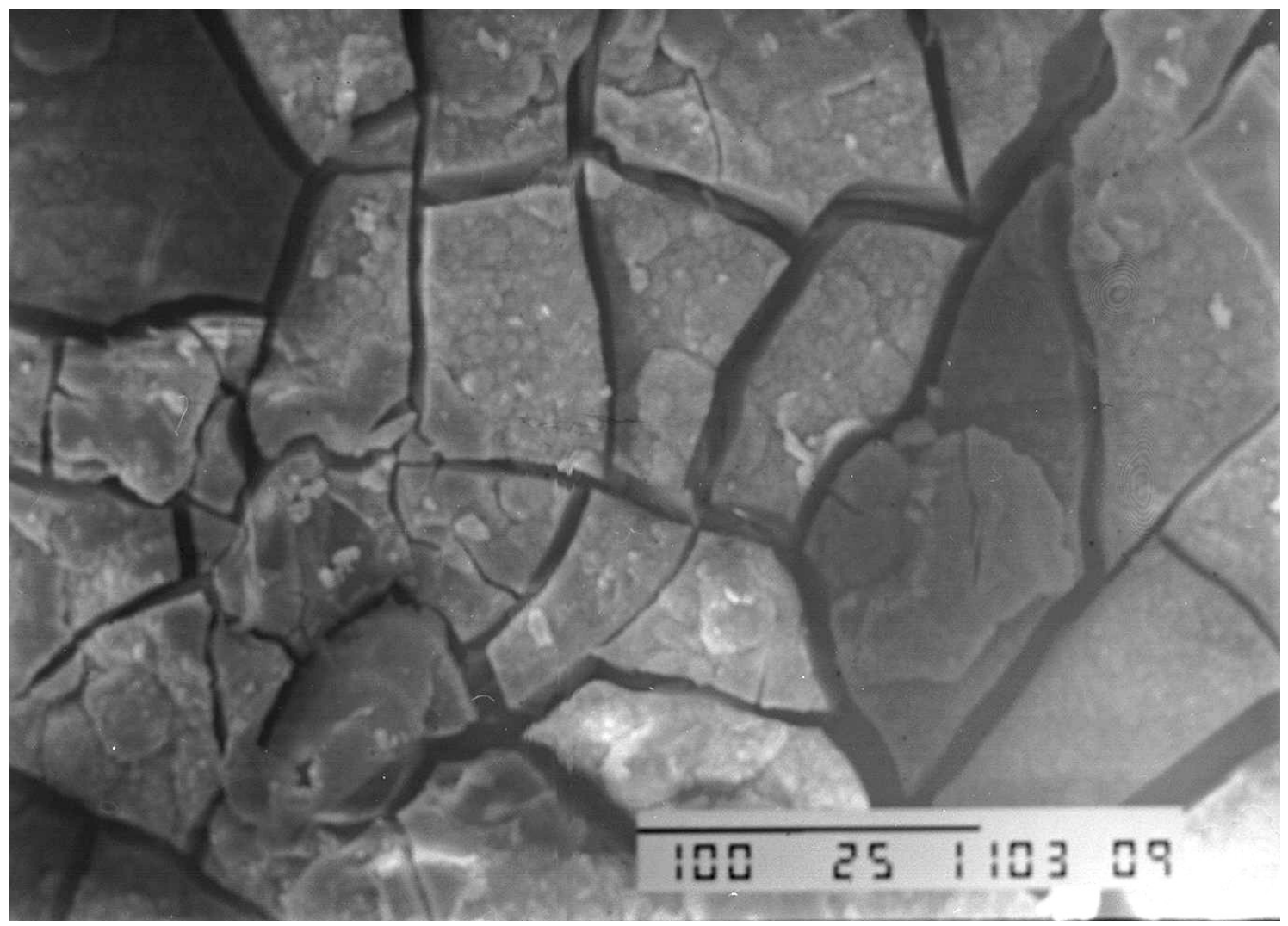

Foto 10 - Gel gretado proveniente da reação álcali-silicato. O gretamento indicando fissuração é resultado do preparo da amostra e efeito da incidência do feixe eletrônico. Microscópio eletrônico de varredura. Ampliação 350x (Acervo ABCP). 


\subsection{Medidas Preventivas}

\section{$>$ Seleção adequada do agregado}

A medida mais eficiente para prevenir a RAA é o uso de agregado não-reativo. No entanto, essa solução nem sempre é prática e economicamente viável porque agregados não-reativos podem não estar disponíveis no local da construção.

A reatividade do agregado pode ser determinada pelo método acelerado das barras de argamassa ASTM C 1260 ou pelo método de longa duração em prismas de concreto - ASTM C 1293. A análise petrográfica permite avaliar a reatividade de agregado com base na identificação das fases reativas presentes no material.

\section{$>$ Limitar o teor de álcalis no concreto}

Expansão deletéria e fissuração do concreto provenientes de RAA podem ser significativamente reduzidas e mesmo prevenidas pelo uso de cimentos com baixos teores de álcalis ou limitando o teor total de álcalis no concreto a um valor especifico, sendo o mais comum recomendado de $3 \mathrm{~kg} / \mathrm{m}^{3} \mathrm{Na}_{2} \mathrm{O}_{\mathrm{e}}$.

Esse limite de segurança se aplica à maioria dos agregados e pode variar de 1,8 a $3 \mathrm{~kg} / \mathrm{m}^{3} \mathrm{Na}_{2} \mathrm{O}_{\mathrm{e}}$, mas, na prática, depende do grau de reatividade do agregado, do teor de álcalis no cimento, do consumo de cimento no concreto $\left(\mathrm{kg} / \mathrm{m}^{3}\right)$, das condições de exposição da estrutura, do projeto da estrutura e da própria análise de risco de ocorrência da reação (Furnier \& Bérubé, 2000; New Zealand, 2003).

\section{$>$ Uso de adições ativas}

A utilização de adições ativas (escória de alto-forno, cinza volante, argila calcinada, metacaulim, sílica ativa e cinza de casca de arroz) ou a combinação delas em teores adequados pode reduzir significativamente e mesmo controlar expansão deletéria relacionada à reação álcali-agregado no concreto. 
Mas, a eficiência das adições ativas varia de acordo com a composição química e mineralógica das adições, da proporção desse material no concreto, do grau de reatividade do agregado e do teor de álcalis do concreto, para a qual pode contribuir também as adições (Malvar et al, 2002).

No Brasil, a escória de alto-forno e as pozolanas de cinza volante e argila calcinada são adicionadas diretamente ao cimento Portland, enquanto metacaulim e sílica ativa podem ser adicionados ao concreto conforme prescreve a norma NBR 12655/2006. Em barragens, às vezes, podem ser adicionados cinza volante e pozolanas diretamente na betoneira.

\subsection{Cimento Portland}

No Brasil são produzidos sete tipos básicos de cimento Portland. Além de clínquer Portland e sulfato de cálcio, esses podem conter adições de fíler calcário, escória de alto-forno ou pozolana (cinza volante ou argila calcinada).

\subsubsection{Clínquer Portland}

O clínquer Portland é o componente básico do cimento, produzido a partir da calcinação a $1450^{\circ} \mathrm{C}$ de uma mistura adequada de calcário e argila. O calcário fornece óxido de cálcio $(\mathrm{CaO})$ e a argila, óxidos de sílicio, alumínio e ferro. As reações de clinquerização entre esses quatro óxidos principais dão origem aos minerais do clínquer Portland: os silicatos de cálcio (alita - $\mathrm{Ca}_{3} \mathrm{SiO}_{5}-\mathrm{C}_{3} \mathrm{~S}$ e belita $\left.\mathrm{Ca}_{2} \mathrm{SiO}_{4}-\mathrm{C}_{2} \mathrm{~S}\right)$ e os aluminatos de cálcio $\left(\mathrm{Ca}_{3} \mathrm{Al}_{2} \mathrm{O}_{6}-\mathrm{C}_{3} \mathrm{~A}\right.$ e $\left.\mathrm{Ca}_{4} \mathrm{Al}_{2} \mathrm{Fe}_{2} \mathrm{O}_{10}-\mathrm{C}_{4} \mathrm{AF}\right)$. Essas fases, simplificadas na notação empregada, não são puras, incorporando elementos menores oriundos das matérias-primas ou da interação com os combustíveis empregados. A Figura 11 esquematiza o processo de fabricação do clínquer Portland. A Foto 11 ilustra os silicatos de cálcio $\left(\mathrm{C}_{3} \mathrm{~S}\right.$ e $\left.\mathrm{C}_{2} \mathrm{~S}\right)$ e a Foto 12 , os aluminatos de cálcio $\left(\mathrm{C}_{3} \mathrm{~A}\right.$ e $\left.\mathrm{C}_{4} \mathrm{AF}\right)$, observados ao microscópio óptico de luz refletida. 


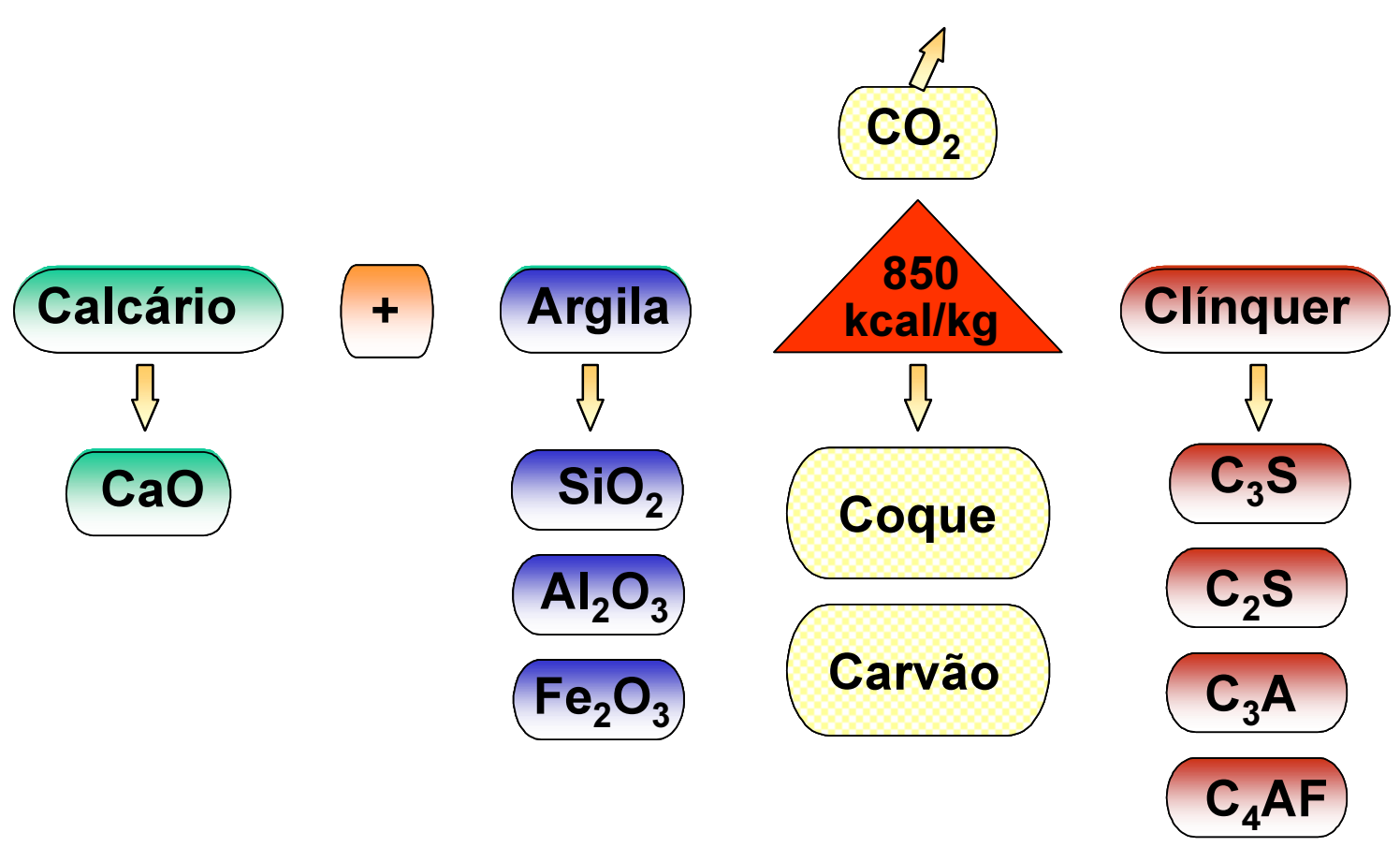

Figura 11 - Ilustração do processo de fabricação do clínquer

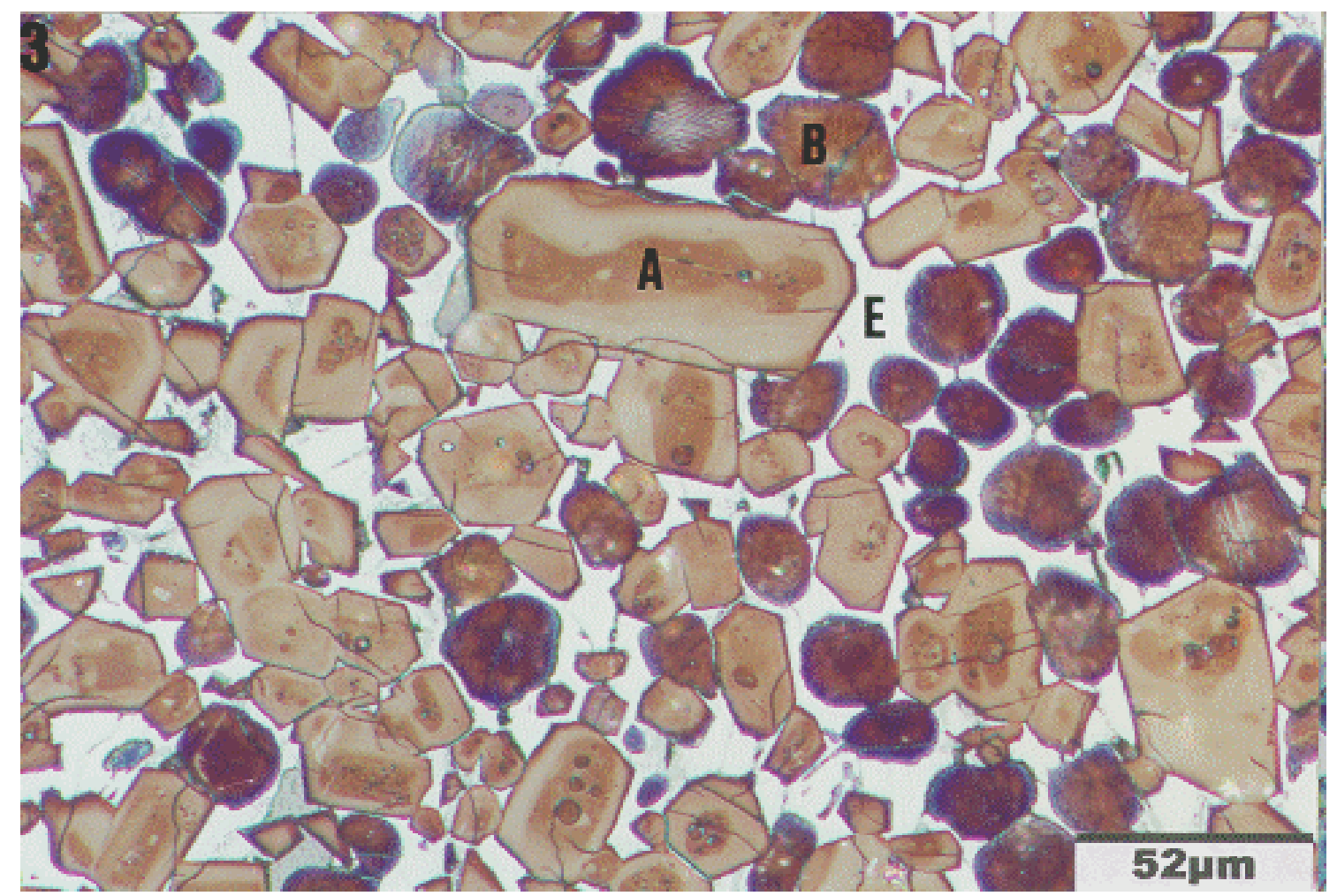

Foto 11 - Cristais idiomórficos de alita $(A)$ e arredondados de belita $(B)$ e fase intersticial $(E)$. Microscopia de luz refletida. Ampliação 400x (Acervo ABCP). 


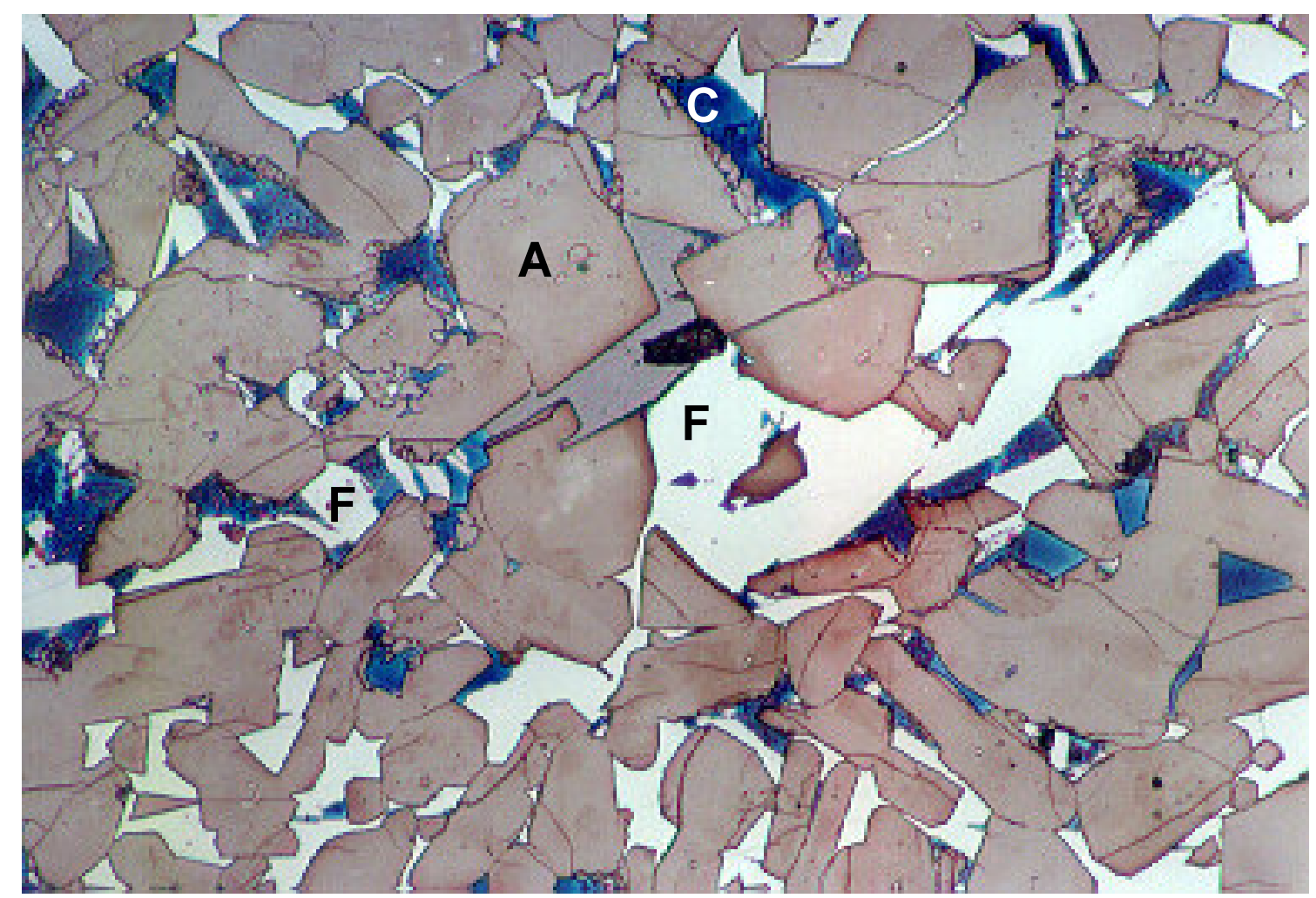

Foto 12 - Fase intersticial cristalizada com nítida diferenciação dos cristais de $C_{3} A(C)$ e $C_{4} A F$ $(F) .(A=$ alita). Microscopia de luz refletida. Ampliação 400x (Acervo ABCP).

Compõem ainda o clínquer Portland as fases cal livre e periclásio, relacionadas à queima incompleta e composição do calcário, respectivamente e as fases sulfatadas arcanita $-\mathrm{K}_{2} \mathrm{SO}_{4}$; langbeinita $-\mathrm{K}_{2} \mathrm{Ca}_{2}\left(\mathrm{SO}_{4}\right)_{3}$; aftitalita $-\mathrm{K}_{3} \mathrm{Na}\left(\mathrm{SO}_{4}\right)_{2}$. Os sulfatos, preferencialmente combinados com os álcalis, são provenientes dos combustíveis e os álcalis, sódio e potássio, da matéria-prima. Os álcalis podem ser encontrados também na estrutura dos silicatos e aluminatos de cálcio (Taylor, 1997).

A composição química e mineralógica do clínquer Portland tem grande influência nas propriedades das pastas de cimento. $\mathrm{C}_{3} \mathrm{~S}, \mathrm{C}_{2} \mathrm{~S}, \mathrm{C}_{3} \mathrm{~A}$ e $\mathrm{C}_{4} \mathrm{AF}$ apresentam reatividades distintas e ocorrem em teores variados. Dentre as quatro fases principais, $\circ \mathrm{C}_{3} \mathrm{~A}$ é o composto mais reativo e que exibe o mais alto calor de hidratação por unidade de massa, tendo expressiva influência no tempo de pega. $\mathrm{Na}$ presença de sulfato de cálcio, $\mathrm{O}_{3} \mathrm{~A}$ altera substancialmente seu processo de hidratação, retardando a pega do cimento Portland (Kihara e Centurione, 2005). 


\subsubsection{Sulfatos de Cálcio}

Os sulfatos de cálcio são utilizados como retardadores da pega durante as reações de hidratação. Reagem com $0 \mathrm{C}_{3} \mathrm{~A}$ formando inicialmente trissulfoaluminato de cálcio (etringita) e num estágio posterior, monosulfoaluminato de cálcio, que impede a formação precoce do aluminato hidratado $\left(\mathrm{C}_{4} \mathrm{AH}_{13}\right)$, um dos componentes responsáveis pela pega do cimento (Kihara e Centurione, 2005).

São vários os tipos de sulfato de cálcio consumidos pela indústria brasileira do cimento: gipsita natural $\left(\mathrm{CaSO}_{4} .2 \mathrm{H}_{2} \mathrm{O}\right)$, do gipso proveniente do Nordeste, ou artificiais, como subproduto da fabricação do ácido fosfórico (Foto 13), e a anidrita, subproduto da produção de ácido fluorídrico.

A gipsita pode se desidratar parcial ou totalmente durante o processo de moagem do cimento, dando origem às formas hemidrato ou bassanita $\left(\mathrm{CaSO}_{4} \cdot 1 / 2 \mathrm{H}_{2} \mathrm{O}\right.$, Foto 14) e anidrita solúvel $\left(\mathrm{CaSO}_{4}\right)$. Esse fato pode dar origem ao aparecimento do fenômeno indesejável de falsa pega durante a hidratação do cimento, comprometendo as propriedades reológicas. O teor de sulfato de cálcio no cimento deve ser otimizado adequando-o ao teor de $\mathrm{C}_{3} \mathrm{~A}$ e álcalis do clínquer e à finura do cimento.

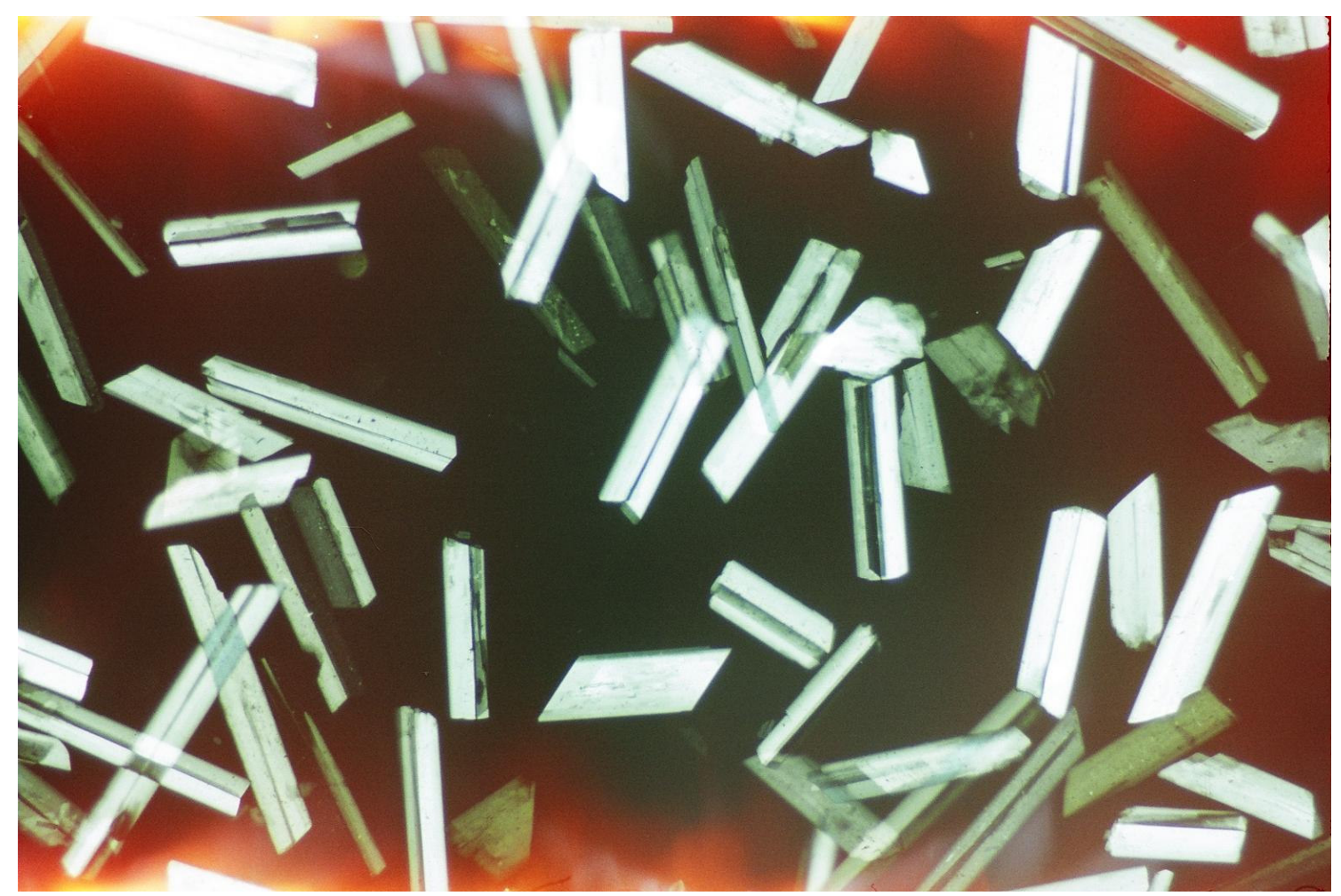

Foto 13 - Cristais prismáticos de gipsita artificial. Microscopia de luz transmitida. Ampliação 100x (Acervo ABCP). 


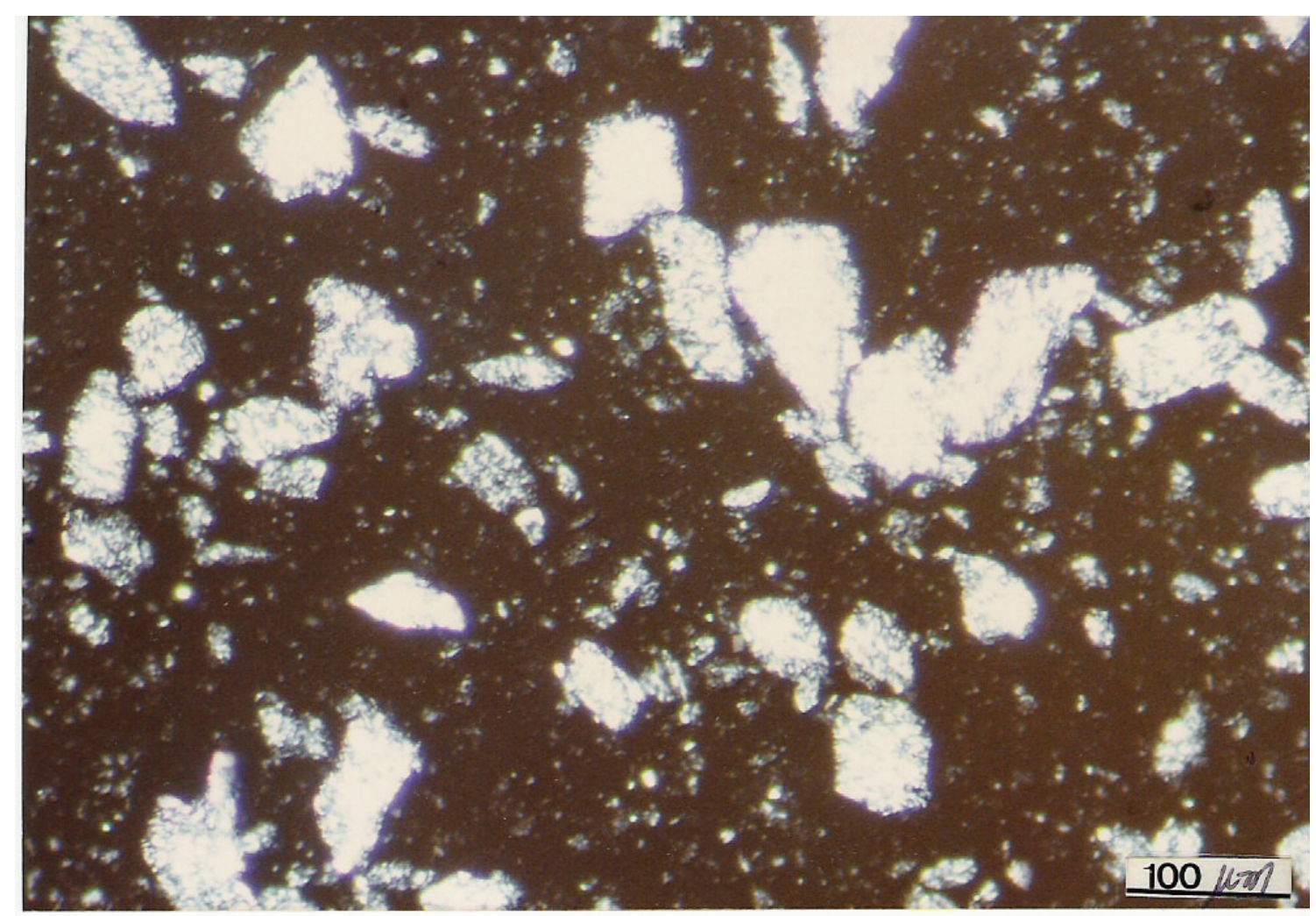

Foto 14 - Grãos irregulares de hemidrato obtidos a partir da desidratação da gipstita de origem natural. Microscopia de luz transmitida. Ampliação 100x (Acervo ABCP).

\subsubsection{Fíler calcário}

A adição de fíler calcário ao cimento Portland reduz os custos de produção, preserva as jazidas minerais e permite menores taxas de emissão de $\mathrm{CO}_{2}$.

A adição de fíler calcário pode aumentar o empacotamento, reduzindo os espaços vazios, e alterar a cinética das reações de hidratação e a morfologia dos produtos hidratados. Os efeitos da adição de fíler dependem da relação água/cimento utilizada e das características físicas do fíler (Yahia, 2005).

As normas de especificação dos cimentos brasileiros limitam o conteúdo de fíler calcário nos cimentos em $10 \%$, sendo que o material carbonático empregado deve ter, no mínimo, $85 \%$ de $\mathrm{CaCO}_{3}$. A Foto 15 ilustra grãos de fíler calcário observados ao microscópio de luz transmitida. 


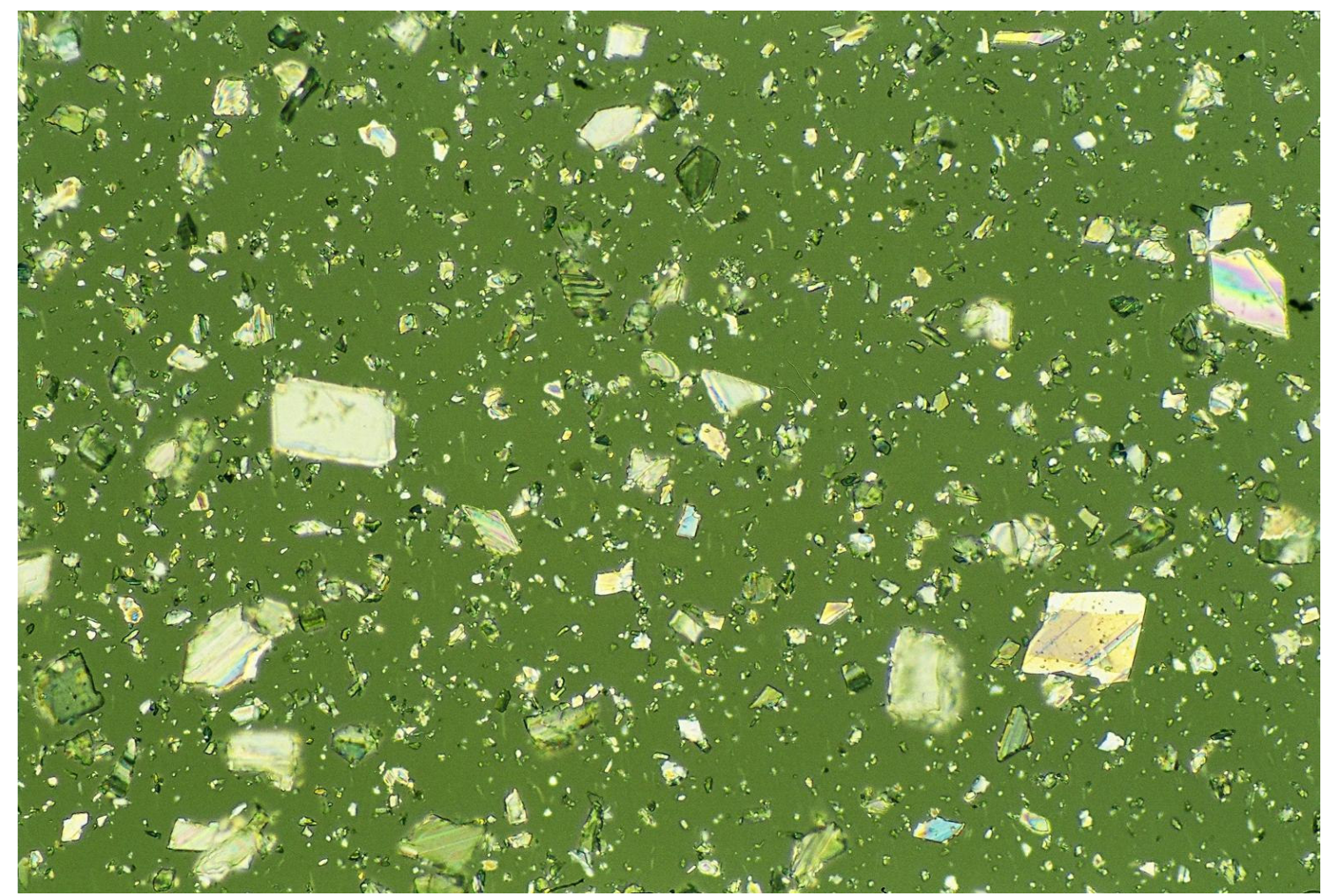

Foto 15 - Grãos de fíler calcário ao microscópio óptico de luz transmitida. Ampliação 80x (Acervo ABCP).

\subsubsection{Adições Ativas ao Cimento Portland}

As adições ativas ao cimento Portland comum proporcionam ligantes com propriedades tecnológicas ligeiramente diferenciadas e, sob alguns aspectos, superiores às do próprio cimento Portland comum.

O uso de adições ativas confere aos cimentos propriedades específicas, tais como: baixo calor de hidratação, baixa permeabilidade, minimização da reação álcaliagregado, resistência ao ataque por sulfatos, além de aumentar as resistências mecânicas e melhorar a durabilidade.

As adições ativas também contribuem para redução significativa da emissão de $\mathrm{CO}_{2}$, preservação de matérias-primas (jazidas de calcário e argila) e de fontes nãorenováveis de combustíveis, além de reciclar do meio ambiente subprodutos de outros processos industriais. 
Dois tipos de materiais se consagraram por sua vantajosa adição ao clínquer Portland: as escórias de alto-forno e os materiais pozolânicos. Considera-se pozolânico todo "material natural ou artificial, silicoso ou sílico-aluminoso, que por si só não possui nenhuma atividade hidráulica, mas que, quando finamente moído e na presença de água, reage com hidróxido de cálcio à temperatura ambiente para formar compostos com propriedades aglomerantes" (NBR 12653, 1992).

O hidróxido de cálcio gerado durante o processo de hidratação do cimento Portland, além de não contribuir para a resistência mecânica, é o composto mais fácil de ser solubilizado e lixiviado. $\mathrm{O} \mathrm{Ca}(\mathrm{OH})_{2}$, ao reagir com os materiais pozolânicos, leva à formação de produtos hidratados (C-S-H) similares aos obtidos da hidratação do clínquer Portland, proporcionando uma estrutura mais compacta, química e mecanicamente mais resistente do que a exibida pelo cimento sem adição. (ZAMPIERI, 1989).

O C-S-H formado por resultar de materiais com baixo teor de cálcio como a cinza volante, ou com teor menor do que o clínquer apresenta menor relação $\mathrm{Ca} / \mathrm{Si}$, o que permite a absorção de íons alcalinos da solução dos poros.

As principais pozolanas adicionadas aos cimentos brasileiros são as cinzas volantes, subproduto da queima do carvão mineral em usinas termelétricas, e as argilas calcinadas, ativadas a temperaturas próximas a $800^{\circ} \mathrm{C}$.

\subsubsection{Escória de alto-forno}

As escórias de alto-forno são subprodutos da fabricação do ferro gusa nos altofornos das usinas siderúrgicas. Para serem adicionadas ao cimento Portland, devem ser vitrificadas por resfriamento brusco e apresentar composição química adequada que Ihes confira caráter básico. As escórias são constituídas, na maior parte, por aluminossilicatos cálcicos sob a forma de grãos vítreos (grau de vitrificação superior a 95\%), com índice de refração $>1,64$ (caráter básico). A Foto 16 mostra grãos vítreos e irregulares de escória de alto-forno empregada pela indústria do cimento. As escórias atualmente utilizadas na indústria do cimento devem obedecer à relação (Battagin e Esper, 1988):

$$
\frac{\mathrm{CaO}+\mathrm{MgO}+\mathrm{Al}_{2} \mathrm{O}_{3}}{\mathrm{SiO}_{2}}>1
$$




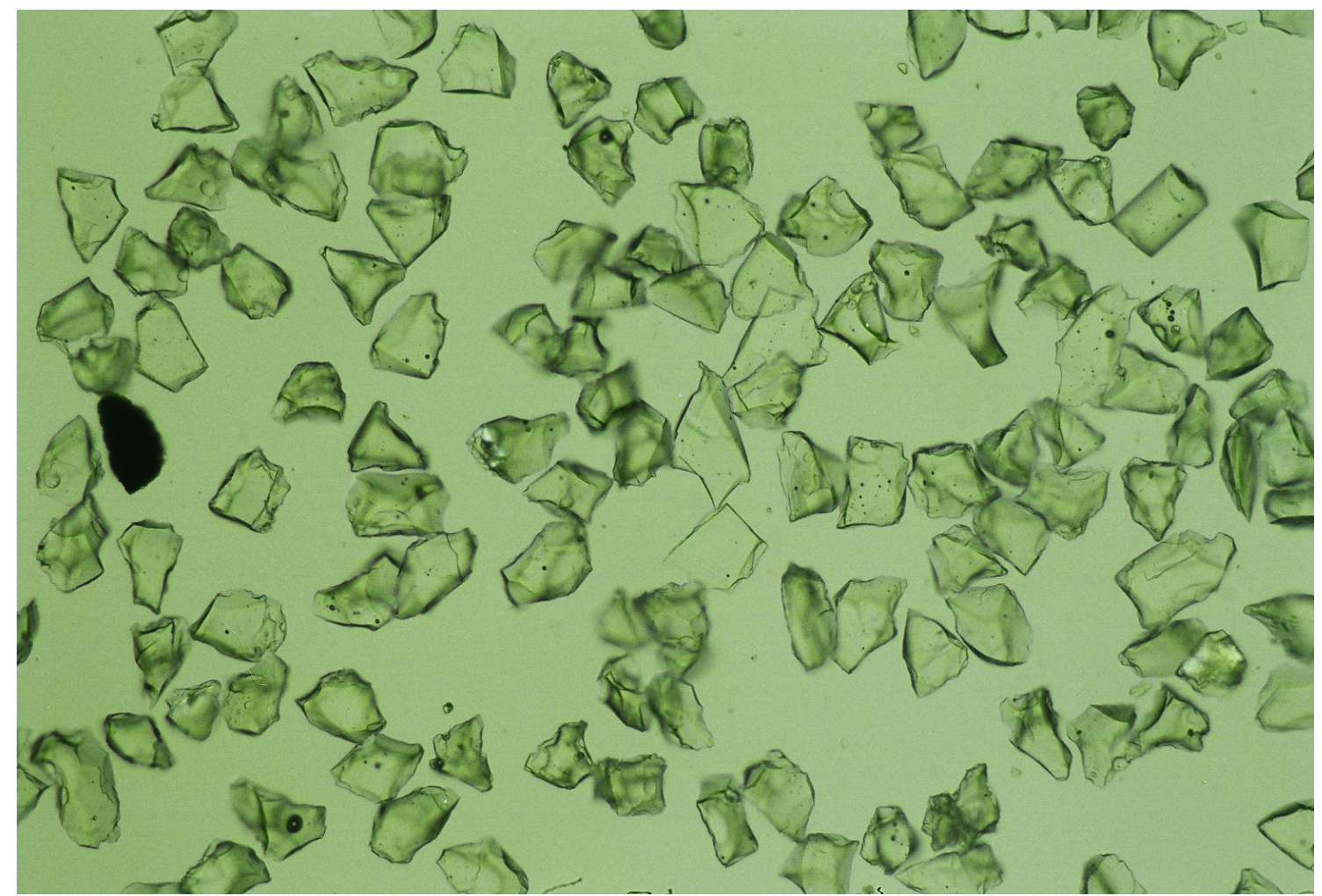

Foto 16 - Grãos de escória essencialmente vítreos, com formas irregulares. Fração

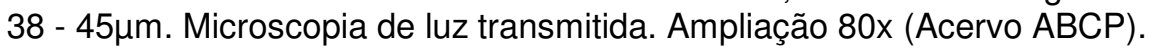

\subsubsection{Cinza volante}

As cinzas volantes são materiais de composição sílico-aluminosa, com teores de $\mathrm{SiO}_{2}$ e $\mathrm{Al}_{2} \mathrm{O}_{3}$ entre $55 \%$ e $69 \%$ e $20 \%$ e $29 \%$, respectivamente. São constituídas por grãos arredondados de fase amorfa, vítrea, de natureza sílico-aluminosa, e secundariamente, por fases cristalinas representadas por quartzo, mulita, hematita e magnetita. Morfologicamente constituem-se por uma mistura de grãos finamente divididos (Foto 17) de superfície lisa, de formas arredondadas a angulosas, esféricas a irregulares, e dimensões variadas (0,5 a 200 $\mu \mathrm{m})$.

As cinzas volantes apresentam-se compactas ou porosas, com inclusões de mulita, quartzo e óxidos metálicos. O desenvolvimento de formas esféricas, características favoráveis e desejáveis no comportamento reológico e mecânico das argamassas e concretos de cimento Portland, ocorre em condições de alta temperatura ou de maior tempo na zona de combustão (KIHARA, 1983). 


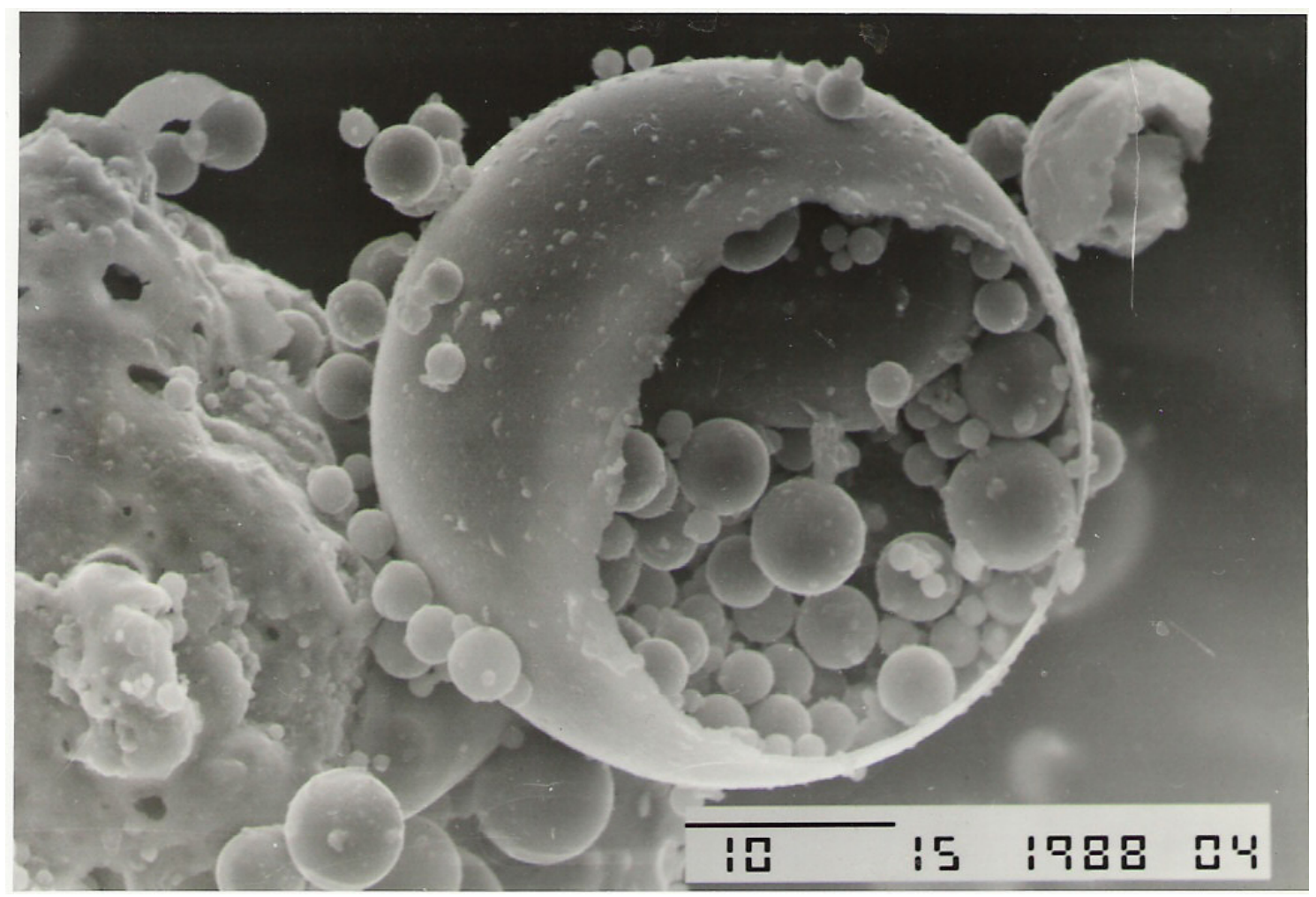

Foto 17 - Micrografia de grãos esféricos de cinza volante obtida ao microscópio eletrônico de varredura. (Plerosferas: caracteriza-se por elevada área específica favorecida por moagem, a qual libera as partículas menores). Ampliação 3500x (Acervo ABCP).

\subsubsection{Argila Calcinada}

As pozolanas de argila calcinada são obtidas de matérias-primas cauliníticas, com teores variados de quartzo. Essas matérias-primas apresentam-se ainda em associação a feldspato, micas, gibbsita e óxidos e hidróxidos de ferro. A ativação térmica das argilas entre $700^{\circ} \mathrm{C}$ a $800^{\circ} \mathrm{C}$ favorece modificações e desarranjos na estrutura cristalina dos argilominerais que, ao final, manifestam-se pela perda da água de cristalização e pela formação de um material atomicamente desarranjado, com alto grau de desordem e elevada área específica (metacaulinita) (Zampieri, 1993). 


\subsubsection{Adições ativas ao Concreto}

A NBR 12655/2006 permite a adição de metacaulim e sílica ativa ao concreto.

\subsubsection{Sílica Ativa}

A sílica ativa, tipo especial de pozolana, é um subproduto da fabricação do ferrosilício ou silício elementar. É formada por partículas esféricas vítreas de natureza silicosa, extremamente fina, de densidade relativa da ordem de $2,2 \mathrm{~g} / \mathrm{cm}^{3}$.

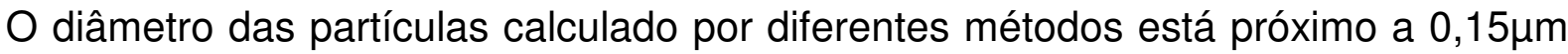
e a área específica determinada pelo método de adsorção de nitrogênio (BET) é da ordem de $20 \mathrm{~m}^{2} / \mathrm{g}$, variando de $15 \mathrm{~m}^{2} / \mathrm{g}$ a $25 \mathrm{~m}^{2} / \mathrm{g}$.

Quimicamente, a sílica ativa é constituída apenas de $\mathrm{SiO}_{2}$. Compõe-se principalmente por fase vítrea, amorfa, silicosa $\left(>86 \% \mathrm{SiO}_{2}\right)$ e, secundariamente, podem ser encontrados compostos cristalinos como carbeto de silício e cristobalita. Essas características conferem à sílica ativa alta reatividade com $\mathrm{Ca}(\mathrm{OH})_{2}$ liberado pela hidratação do clínquer Portland. Embora haja alguns fabricantes que adicionam sílica ativa no processo de fabricação do cimento, seu uso é mais expressivo no concreto (Kihara, Bucher, 1986).

A substituição de cimento Portland comum por sílica ativa nos teores de $5 \% ; 10 \%$ e $15 \%$ aumenta significativamente a tensão de escoamento e a viscosidade das pastas, à medida que se aumenta o teor de adição Esse fato é atribuído à elevada área específica das partículas de sílica ativa e à sua reatividade (Park, 2005).

\subsubsection{Metacaulim}

Metacaulim de alta reatividade (MCAR), termo utilizado para distingui-lo das pozolanas de argila calcinada que contêm minerais não passíveis de ativação térmica, é obtido a partir da calcinação de matérias-primas constituídas essencialmente pelo mineral caulinita $\left(\mathrm{Al}_{2} \mathrm{Si}_{2} \mathrm{O}_{5}(\mathrm{OH})_{4}\right)(\mathrm{Dal}$ Molin, 2005): 
Argilas cauliníticas e caulins, após ativação térmica entre $650-800^{\circ} \mathrm{C}$, perdem os íons hidroxila de sua estrutura cristalina, transformando-se em metacaulinita $\left(\mathrm{Al}_{2} \mathrm{Si}_{2} \mathrm{O}_{7}\right)$, composto amorfo com elevada desordem cristalina. A metacaulinita é capaz de reagir com hidróxido de cálcio gerado durante a hidratação do cimento Portland e formar produtos hidratados similares aos decorrentes da hidratação direta do clínquer Portland (Ramlochan, Thomas e Gruber, 2000)

A adição de metacaulim aumenta significativamente a tensão de escoamento em relação aos cimentos sem adição devido à maior demanda de água, ocasionada pela elevada área específica da metacaulinita. (Moulin, 2001).

\subsubsection{Tipos de Cimento Portland}

A Figura 12 ilustra os tipos de cimento produzidos no Brasil bem como os teores de adição permitidos por norma. As Tabela 4 e 5 apresentam as prescrições químicas e físico-mecânicas.

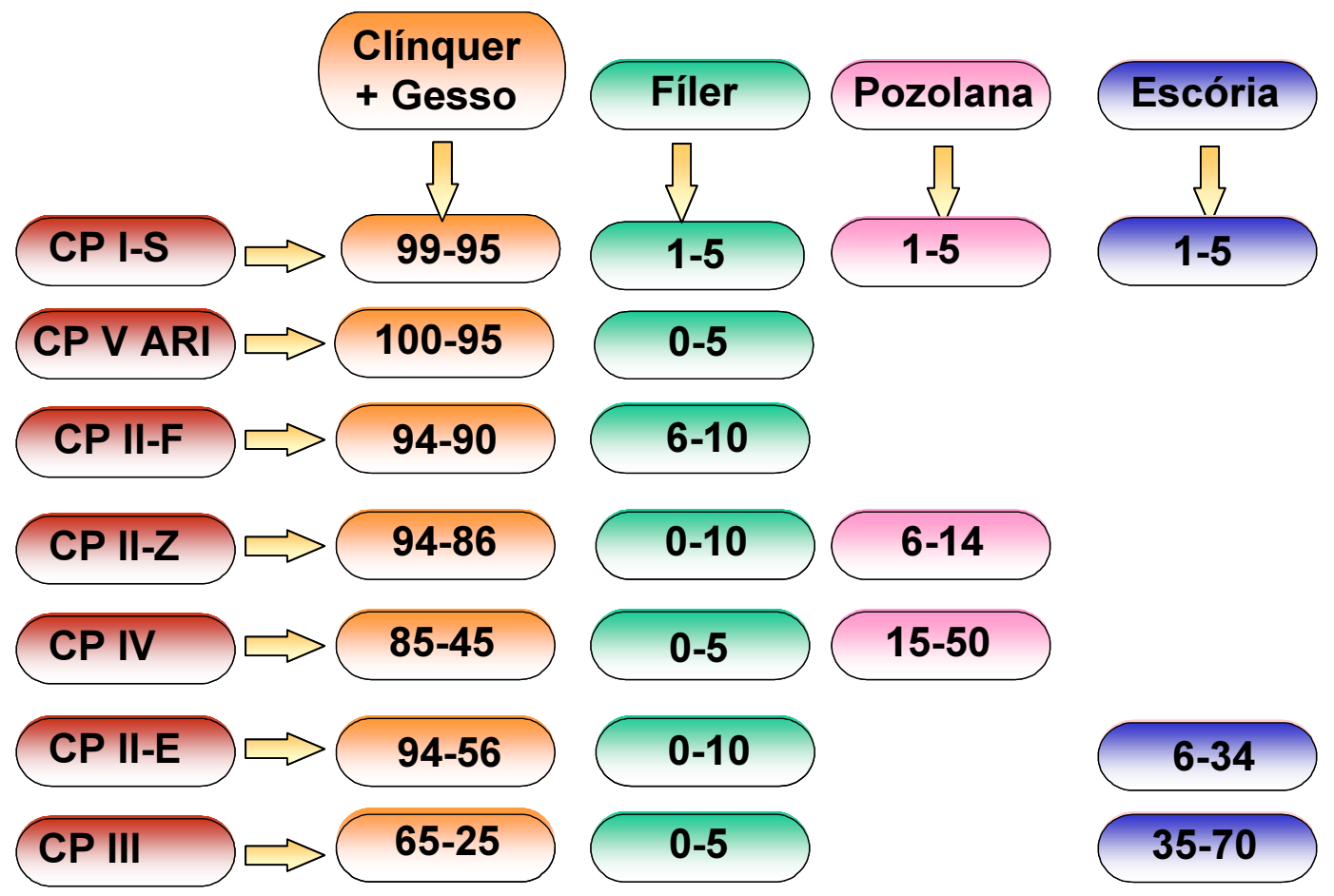

Figura 12 - Tipos de cimentos produzidos no Brasil e teores de adição permitidos por norma 
Tabela 4 - Prescrições químicas dos cimentos brasileiros

\begin{tabular}{|c|c|c|c|c|c|c|}
\hline $\begin{array}{l}\text { Tipo de } \\
\text { cimento } \\
\text { Portland }\end{array}$ & $\begin{array}{c}\text { Resíduo } \\
\text { insolúvel } \\
(\%)\end{array}$ & $\begin{array}{l}\text { Perda ao } \\
\text { fogo }(\%)\end{array}$ & $\mathrm{MgO}(\%)$ & $\mathrm{SO}_{3}(\%)$ & $\mathrm{CO}_{2}(\%)$ & S (\%) \\
\hline $\begin{array}{l}\text { CP I } \\
\text { CP I-S }\end{array}$ & $\begin{array}{l}\leq 1,0 \\
\leq 5,0\end{array}$ & $\begin{array}{l}\leq 2,0 \\
\leq 4,5\end{array}$ & $\leq 6,5$ & $\leq 4,0$ & $\begin{array}{l}\leq 1,0 \\
\leq 3,0\end{array}$ & $\begin{array}{l}-- \\
--\end{array}$ \\
\hline $\begin{array}{l}\text { CP II-E } \\
\text { CP II-Z } \\
\text { CP II-F }\end{array}$ & $\begin{array}{l}\leq 2,5 \\
\leq 16,0 \\
\leq 2,5\end{array}$ & $\leq 6,5$ & $\leq 6,5$ & $\leq 4,0$ & $\leq 5,0$ & $\begin{array}{l}-- \\
-- \\
--\end{array}$ \\
\hline CP III & $\leq 1,5$ & $\leq 4,5$ & -- & $\leq 4,0$ & $\leq 3,0$ & $\leq 1,0$ \\
\hline CP IV & -- & $\leq 4,5$ & $\leq 6,5$ & $\leq 4,0$ & $\leq 3,0$ & -- \\
\hline CP V-ARI & $\leq 1,0$ & $\leq 4,5$ & $\leq 6,5$ & $\begin{array}{c}\leq 3,5 \text { para } \\
\mathrm{C}_{3} \mathrm{~A} \leq 8 \% \\
\leq 4,5 \text { para } \\
\mathrm{C}_{3} \mathrm{~A}>8 \%\end{array}$ & $\leq 3,0$ & -- \\
\hline
\end{tabular}

Tabela 5 - Prescrições físico-mecânicas dos cimentos brasileiros

\begin{tabular}{|c|c|c|c|c|c|c|c|c|c|c|c|}
\hline \multirow{2}{*}{ 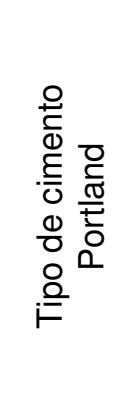 } & \multirow[b]{2}{*}{$\begin{array}{l}0 \\
0 \\
0 \\
\tilde{D} \\
0\end{array}$} & \multicolumn{2}{|c|}{ Finura } & \multicolumn{2}{|c|}{$\begin{array}{l}\text { Tempos de } \\
\text { pega (h) }\end{array}$} & \multicolumn{2}{|c|}{$\begin{array}{c}\text { Expansibilidade } \\
(\mathrm{mm})\end{array}$} & \multicolumn{4}{|c|}{$\begin{array}{l}\text { Resistência à compressão } \\
(\mathrm{MPa})\end{array}$} \\
\hline & & 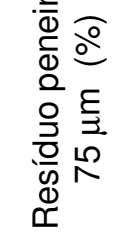 & 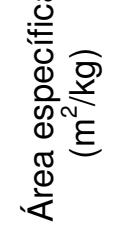 & $\stackrel{\frac{O}{0}}{\underline{\underline{O}}}$ & $\underline{\underline{E}}$ & 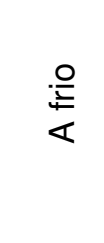 & $\begin{array}{l}\frac{0}{ \pm} \\
\frac{0}{0} \\
\frac{\partial}{0}\end{array}$ & $\stackrel{\frac{\pi}{0}}{-}$ & $\begin{array}{l}0 \\
.00 \\
\frac{0}{0} \\
m\end{array}$ & $\begin{array}{l}0 \\
\frac{0}{0} \\
\frac{0}{0} \\
1\end{array}$ & $\begin{array}{l}\stackrel{0}{0} \\
\frac{\pi}{0} \\
\stackrel{0}{N} \\
\stackrel{N}{N}\end{array}$ \\
\hline $\begin{array}{l}\text { CPI } \\
\text { CP I-S }\end{array}$ & $\begin{array}{l}25 \\
32 \\
40\end{array}$ & $\begin{array}{l}\leq 12,0 \\
\leq 12,0 \\
\leq 10,0\end{array}$ & $\begin{array}{l}\geq 240 \\
\geq 260 \\
\geq 280\end{array}$ & $\geq 1$ & $\leq 10$ & $\leq 5$ & $\leq 5$ & -- & $\begin{array}{l}\geq 8 \\
\geq 10 \\
\geq 15\end{array}$ & $\begin{array}{l}\geq 15 \\
\geq 20 \\
\geq 25\end{array}$ & $\begin{array}{l}\geq 25 \\
\geq 32 \\
\geq 40\end{array}$ \\
\hline $\begin{array}{l}\text { CP II-E } \\
\text { CP II-Z } \\
\text { CP II-F }\end{array}$ & $\begin{array}{l}25 \\
32 \\
40\end{array}$ & $\begin{array}{l}\leq 12,0 \\
\leq 12,0 \\
\leq 10,0\end{array}$ & $\begin{array}{l}\geq 240 \\
\geq 260 \\
\geq 280\end{array}$ & $\geq 1$ & $\leq 10$ & $\leq 5$ & $\leq 5$ & -- & $\begin{array}{l}\geq 8 \\
\geq 10 \\
\geq 15\end{array}$ & $\begin{array}{l}\geq 15 \\
\geq 20 \\
\geq 25\end{array}$ & $\begin{array}{l}\geq 25 \\
\geq 32 \\
\geq 40\end{array}$ \\
\hline CP III & $\begin{array}{l}25 \\
32 \\
40\end{array}$ & $\leq 8,0$ & -- & $\geq 1$ & $\leq 12$ & $\leq 5$ & $\leq 5$ & -- & $\begin{array}{l}\geq 8 \\
\geq 10 \\
\geq 12\end{array}$ & $\begin{array}{l}\geq 15 \\
\geq 20 \\
\geq 23\end{array}$ & $\begin{array}{l}\geq 25 \\
\geq 32 \\
\geq 40\end{array}$ \\
\hline CP IV & $\begin{array}{l}25 \\
32\end{array}$ & $\leq 8,0$ & -- & $\geq 1$ & $\leq 12$ & $\leq 5$ & $\leq 5$ & -- & $\begin{array}{l}\geq 8 \\
\geq 10\end{array}$ & $\begin{array}{l}\geq 15 \\
\geq 20\end{array}$ & $\begin{array}{l}\geq 25 \\
\geq 32\end{array}$ \\
\hline CP V-AP & & $\leq 6,0$ & $\geq 300$ & $\geq 1$ & $\leq 10$ & $\leq 5$ & $\leq 5$ & $\geq 14$ & $\geq 24$ & $\geq 34$ & -- \\
\hline
\end{tabular}




\subsubsection{Composição dos Cimentos Industriais em 2003}

Com base em dados do SNIC (2003) e informações da Associação Brasileira de Cimento Portland referentes ao controle de qualidade dos cimentos produzidos no Brasil, determinou o teor médio de cada adição mineral presente nos vários tipos de cimento. Os cimentos CP II-Z e CP IV produzidos na região Sul utilizam cinza volante como pozolana, enquanto os das regiões Norte e Nordeste, empregam argila calcinada. A Figura 13 ilustra os resultados obtidos (Munhoz, 2004).

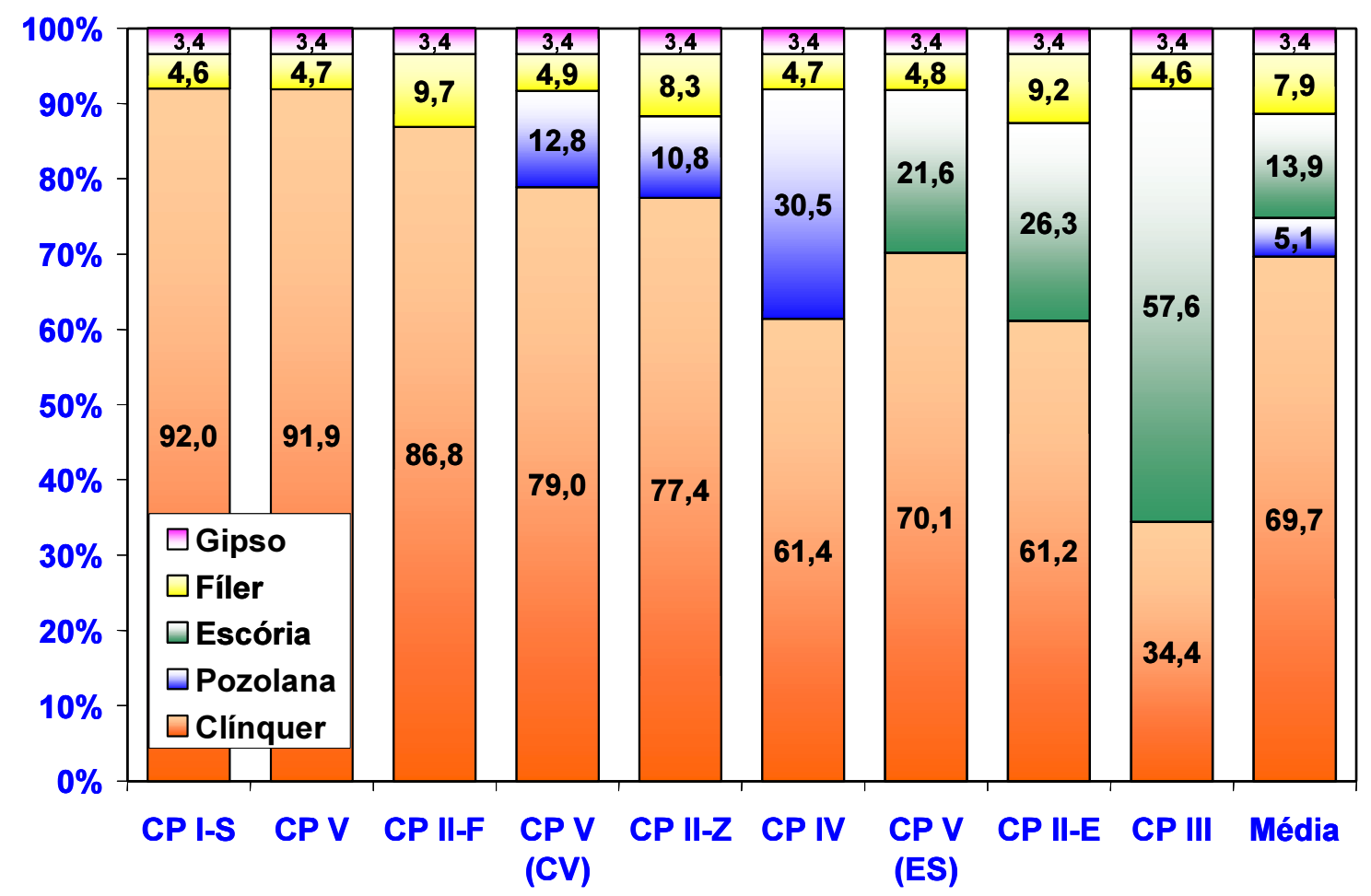

Figura 13 - Teor médio de adição por tipo de cimento em 2003

Os cimentos mais eficientes na minimização da reação álcali-agregado são os de alto-forno (CP III) e os pozolânicos (CP IV), que representaram $13 \%$ e $8 \%$ da produção nacional em 2003, respectivamente. Os outros tipos de cimento, menos eficientes na minimização da reação álcali-agregado, representaram $79 \%$ da produção nacional em 2003 (SNIC, 2003). 
$\mathrm{Na}$ ausência de um cimento Portland adequado à minimização da RAA e na impossibilidade de troca pode-se adicionar metacaulim ou sílica ativa em quantidades adequadas ao concreto para assegurar a minimização da RAA para níveis aceitáveis.

Malvar et al. (2002) menciona que a adição de aproximadamente 25\% de cinza volante com baixo teor de cálcio em substituição ao cimento Portland reduz significativamente a expansão proveniente da reação álcali-sílica da maioria dos agregados e é o valor recomendado por instituições públicas e privadas de vários países.

Escória de alto-forno apresenta vantagens semelhantes às da cinza volante, mas quando adicionada em teores maiores. Enquanto teores de adição de cinza volante encontram-se entre 15 e 40\%, os de escória de alto forno estão entre 25 e 70\%. Normalmente é necessário o dobro de escória de alto-forno em relação à cinza volante para reduzir a expansão álcali-sílica aos mesmos níveis (Malvar et al.,2002).

Hasparyk (1999), investigando a eficiência da cinza de casca de arroz e sílica ativa na minimização da expansão, constatou que o teor ótimo de adição ao cimento é de $15 \%$ para os agregados dos tipos basalto e quartzito analisados, embora $12 \%$ de ambas as adições seja suficiente para reduzir a expansão para os níveis recomendados pela ASTM C 1567, ou seja, inferior a 0,10\% aos 14 dias de cura em solução alcalina.

Ramlochan, Thomas, Gruber (1999) comprovaram a eficiência do metacaulim em controlar a expansão causada pela reação álcali-sílica quando adicionado em substituição parcial ao cimento Portland. Os ensaios realizados em prismas de concreto indicaram que 10 a 15\% de adição de metacaulim é suficiente para mitigar a reação, dependendo do tipo de agregado.

Sibbick, Nixon (2000) obtiveram resultados semelhantes. A adição de $10 \%$ de metacaulim foi suficiente para mitigar a reação de três agregados reconhecidamente reativos. Os ensaios foram realizados em prismas de concreto a $38^{\circ} \mathrm{C}$ e $100 \%$ de umidade durante 24 meses. 
Sales (2006), estudando a eficiência de adições ativas em mitigar a expansão de agregado basalto, concluiu que a substituição parcial de cimento Portland por $10 \%$ e $15 \%$ de sílica ativa e metacaulim, respectivamente, foi suficiente para reduzir a expansão para níveis inferiores a $0,10 \%$ aos 14 dias de cura em solução alcalina. $A$ sílica ativa foi mais eficiente que o metacaulim, pois, mesmo em teor menor, sua expansão foi menor aos 14 dias.

Efeitos sinérgicos foram observados quando da utilização de dois tipos de adição ao mesmo tempo em substituição ao cimento Portland. Níveis de adição menores são necessários quando da utilização de duas adições em conjunto para o mesmo nível de redução da expansão (Malvar et al., 2002).

Os métodos mais comuns utilizados para avaliar a eficiência das adições ativas na minimização da expansão devida à reação álcali-agreado são o do prisma de concreto (ASTM C 1293) e o método acelerado das barras de argamassa (ASTM C 1567).

\subsection{Mecanismo de Minimização da RAS das Adições Ativas}

Existem quatro teorias propostas para explicar a eficiência das adições ativas em reduzir a expansão: 1) diluição dos álcalis, 2) maior retenção dos álcalis na estrutura do silicato de cálcio hidratado (C-S-H), 3) redução da permeabilidade e 4) redução do $\mathrm{pH}$. Entretanto, não há consenso no meio técnico sobre esses mecanismos (Glasser, 1992).

Diluição dos álcalis: a principal fonte de álcalis do cimento Portland é o clínquer Portland. À medida que o clínquer é substituído pelas adições ativas, há diluição dos álcalis, desde que o teor de álcalis das adições seja menor que o do clínquer. Nem todos os álcalis presentes nas adições estão disponíveis na solução dos poros para a reação álcali-agregado.

Retenção dos álcalis no C-S-H: o silicato de cálcio hidratado, formado a partir da reação do hidróxido de cálcio proveniente da hidratação do cimento Portland com as adições ativas, retém os álcalis na estrutura, deixando-os indisponíveis para reagirem com os agregados, evitando assim a expansão. 
Chatterji (1979) mostrou que a presença de $\mathrm{Ca}(\mathrm{OH})_{2}$ é necessária para o desenvolvimento da reação. Uma quantidade adequada de material pozolânico resulta na conversão do hidróxido de cálcio em $\mathrm{C}-\mathrm{S}-\mathrm{H}$, com uma relação $\mathrm{CaO} / \mathrm{SiO}_{2}$ menor. Isso favorece a incorporação dos álcalis na sua estrutura, prevenindo então a participação na reação com as partículas de sílica.

$\mathrm{O}$ C-S-H com alta relação molar $\mathrm{CaO} / \mathrm{SiO}_{2}$ não incorpora álcalis à sua estrutura, e não previne a reação. Quanto maior a quantidade de sílica (ácido) dos materiais pozolânicos e menor a quantidade de cálcio (base), maior será a eficiência em prevenir a reação álcali-agregado. O efeito das pozolanas é reduzir a basicidade dos produtos hidratos do cimento Portland.

Redução da permeabilidade: as adições ativas reduzem a permeabilidade do concreto através do refinamento do tamanho dos poros, tornando-o mais impermeável, reduzindo o ingresso de umidade e a difusão dos álcalis para reagirem com os minerais.

Redução do pH: a reação do hidróxido de cálcio gerado pela hidratação do cimento com os componentes reativos das adições ativas, reduz o hidróxido de cálcio e, conseqüentemente, o pH necessário para o desenvolvimento da reação álcali-sílica.

A diluição dos álcalis, a redução da permeabilidade do concreto e o consumo do $\mathrm{Ca}(\mathrm{OH})_{2}$ pela reação pozolânica, contribuem beneficamente para a redução da expansão de RAS (Bérubé \& Furnier, 2000; Tomas, 1996).

A sílica ativa é composta por sílica amorfa que reage com hidróxido de cálcio (reação pozolânica) e com hidróxidos alcalinos. A reação pozolânica é normalmente considerada o principal mecanismo pelo qual a RAA é controlada ou mitigada (Wang, Gillott, 1992).

Arano et al. (1989), estudando a influência das adições ativas na minimização da reação álcali-agregado, mencionam que a adição de $20 \%$ de cinza volante reduziu significativamente a expansão, graças à redução da concentração de íons hidroxila na solução dos poros, mesmo com a formação de gel. 
Já com o mesmo teor de escória de alto forno, a redução foi pouco significativa. A quantidade e a composição do gel não foram afetadas pela adição de escória em relação às barras sem adição.

No caso da sílica ativa, a adição de apenas $10 \%$ contribuiu para a minimização da reação álcali-agregado, pois não houve formação de gel. Esse fato é atribuído à redução da concentração de íons hidroxila na solução dos poros, favorecida pela reação pozolânica.

As cinzas volantes de baixo teor de cálcio $(<8 \%)$ são mais eficientes na minimização da RAA em comparação às cinzas com alto teor de cálcio. À medida que o teor de cálcio presente na cinza volante aumenta, é necessário aumentar a adição ao cimento Portland para obter o mesmo grau de eficiência na redução da expansão (Thomas et al., 1999).

Shehata, Thomas (1999) demonstraram que o teor de cinza volante necessário para reduzir a alcalinidade da solução dos poros para um mesmo nível, aumenta com o teor de cálcio. Cinzas volantes com alto teor de cálcio não têm a mesma capacidade de reduzir a relação $\mathrm{Ca} / \mathrm{Si}$ dos produtos hidratados do cimento Portland, deixando a solução dos poros mais alcalina em relação às de baixo teor, não contribuindo para a redução da expansão.

O teor de álcalis na solução dos poros tem influência direta sobre a expansão de barras de argamassa aos 14 dias de cura em solução alcalina. Entretanto, a redução da expansão não pode ser explicada apenas pela redução da alcalinidade da solução dos poros. Os autores acreditam que a redução da disponibilidade de cálcio no sistema também tem papel importante na minimização da expansão.

Segundo Ramlochan, Thomas, Gruber (1999), a eficiência do metacaulim em mitigar a expansão causada pela reação álcali-sílica está relacionada à reação pozolânica. A formação de C-S-H adicional com baixa relação Ca:Si (entre 0,8 e 1,5) favorece a retenção dos álcalis na estrutura e, conseqüentemente, reduz a alcalinidade da solução dos poros ao teor de portlandita residual. 
Em outro estudo, o teor de hidróxido de cálcio foi praticamente eliminado em pastas de cimento contendo $20 \%$ de metacaulim, indicando a capacidade de reação pozolânica do material (Larbi,1991 apud Sibbick, Nixon, 2000).

\subsection{Minimização da RAS Utilizando Sais de Lítio}

Os primeiros estudos realizados com sais de lítio para mitigar a RAA foram desenvolvidos por McCoy e por Caldwell em 1951 e Lawrence e Vivian em 1961, sendo retomados apenas na década de 90 (FENG et al., 2005).

FENG et al. (2005), no levantamento realizado sobre os principais sais de lítio indicados para minimizar a reação álcali-agregado, mencionam que todos os sais de lítio investigados (ver Tabela 6) contribuem para a minimização da reação álcaliagregado, quando dosados adequadamente. A eficiência desses sais na minimização da expansão depende principalmente da natureza ou reatividade do agregado, da forma do sal de lítio e da quantidade de álcalis-presente no sistema.

Os estudos indicam que aproximadamente metade da quantidade de lítio adicionada para minimizar a RAA é absorvida pela hidratação do cimento e a retenção do lítio pelo C-S-H é maior do que do sódio e do potássio, ficando disponível somente metade do lítio adicionado para minimizar a reação.

A dosagem do lítio é determinada com base na relação molar [(Li)/(Na+K)]. Para a maioria dos sais de lítio investigada, a dosagem mais eficiente para minimizar a expansão adequadamente está entre 0,67 a 1,20. No caso do $\mathrm{LiNO}_{3}$, a relação molar está entre 0,72 a 0,93.

$\mathrm{LiOH}$ e $\mathrm{LiNO}_{3}$ são mais eficientes na prevenção da expansão de agregados de alta reatividade do que daqueles de baixa reatividade. Dentre todos os sais de lítio, o $\mathrm{LiNO}_{3}$ é o mais eficiente pelo fato de não aumentar a concentração de íons $\mathrm{OH}^{-}$na solução dos poros, ser neutro e altamente solúvel. 
A eficiência dos sais de lítio na minimização da RAA foi investigada principalmente através do método da ASTM C 227, que consiste em moldar barras de argamassa nas dimensões $(25 \times 25 \times 285) \mathrm{mm}$ com relação cimento:agregado 1:2,25 e submetêlas a uma atmosfera saturada de vapor de água na temperatura de $(38 \pm 2)^{\circ} \mathrm{C}$ durante 12 meses. A variação de comprimento, expressa em porcentagem de expansão, é avaliada nas idades de 1, 2, 3, 4, 6, 9 e 12 meses.

Valores de expansão superiores a $0,05 \%$ aos 3 meses ou $0,10 \%$ aos 6 meses são considerados pela ASTM C 33 excessivos e indicam reatividade potencial deletéria do agregado.

O método de autoclave utilizado por alguns pesquisadores, embora rápido, não apresenta resultados diretamente comparáveis aos outros estudos envolvendo temperaturas e pressões menores.

Segundo FENG et al. (2005), há vários mecanismos para explicar a minimização da expansão devida à reação álcali-agregado na presença dos sais de lítio. Esses mecanismos estão baseados principalmente na natureza dos produtos de reação, na dissolução da sílica e na repolimerização do gel.

O lítio é capaz de alterar a natureza dos produtos de reação álcali-agregado, tornando o complexo lítio-sílica (gel) menos solúvel e mais estável. Essa característica faz com que o gel proteja a sílica de outros ataques alcalinos. Resultados de microanálise indicaram que a relação $\mathrm{CaO} / \mathrm{SiO}_{2}$ do gel diminui à medida que a dosagem de lítio aumenta, e que a composição do gel torna-se mais homogênea em teores elevados de lítio. As pesquisas indicam que a reação lítiosílica é mais favorável do que sódio-sílica ou potássio-sílica.

Os efeitos do lítio na minimização da RAA também podem ser atribuídos à redução da dissolução da sílica, com conseqüente redução dos produtos de reação responsáveis pela expansão. Estudos revelaram que há uma redução da dissolução da sílica à medida que o teor de lítio aumenta (Collins et al., 2004). 
A teoria da repolimerização do gel foi proposta por Kurtis et al. (2000), que sugeriram que o efeito do lítio na minimização da RAA não depende unicamente da quantidade de sílica dissolvida, mas da limitação do gel em se repolimerizar quando na presença de lítio, reduzindo seu potencial de expansão.

Para FENG et al. (2005), todas as teorias propostas são coerentes, mas não explicam todos os mecanismos envolvendo os sais de lítio. Essas teorias concordam que o gel formado entre a reação do lítio com a sílica, na ausência de sódio e potássio, não é expansivo. Quando sódio e potássio estão presentes, há uma dosagem adequada de lítio em que o gel deixa de ser expansivo e passa a não-expansivo. A questão é saber qual é essa dosagem e qual é o mecanismo principal da redução da expansão.

Hasparyk (2005) avaliou a eficiência dos sais de lítio em combater a RAA de corpos de prova extraídos da Usina Hidrelétrica de Furnas, com evidências da reação álcaliagregado, e moldados em laboratório e conclui que o lítio é capaz de reduzir parte da expansão residual do concreto extraído, entretanto não foi tão eficiente nos corpos-de-prova moldados em laboratório. Estudos por ressonância magnética nuclear indicaram que o lítio é capaz de afetar a estrutura do gel exsudado nas ligações do silício. 
Tabela 6 - Síntese dos principais trabalhos sobre minimização da expansão devida à reação álcali-agregado, utilizando sais de lítio

\begin{tabular}{|c|c|c|c|c|c|c|}
\hline $\begin{array}{l}\text { Research } \\
\text { work }\end{array}$ & $\begin{array}{l}\text { Testing } \\
\text { method }\end{array}$ & $\begin{array}{l}\text { Reactive } \\
\text { aggregate }\end{array}$ & $\begin{array}{l}w / c \\
\text { ratioby } \\
\text { mass }\end{array}$ & $\begin{array}{l}\text { Total } \\
\mathrm{Na}_{2} \mathrm{Oe} \% \text {, } \\
\text { by mass }\end{array}$ & $\begin{array}{l}\text { Lithium salt } \\
\text { (s) studied }\end{array}$ & $\begin{array}{l}\text { Minimum lithium to alkali } \\
\text { molar ratio }\end{array}$ \\
\hline $\begin{array}{l}\text { McCoy \& } \\
\text { Caldwell }\end{array}$ & ASTM C 227 & Pyrex glass & & 1.15 & $\begin{array}{l}\mathrm{LiCl}, \quad \mathrm{LiF}, \quad \mathrm{Li}_{2} \mathrm{CO}_{3}, \\
\mathrm{Li}_{2} \mathrm{SiO}_{3}, \mathrm{Li}_{2} \mathrm{SO}_{4}, \mathrm{LiNO}_{3}\end{array}$ & 0.74 \\
\hline $\begin{array}{l}\text { Lawrence } \\
\& \text { Vivian }\end{array}$ & ASTM C 227 & Opaline rock & 0.5 & $0.5-1.5$ & $\mathrm{LiOH}$ & \\
\hline \multirow[t]{2}{*}{$\begin{array}{l}\text { Sakaguchi } \\
\text { et al. }\end{array}$} & ASTM C 227 & Pyrex glass & 0.55 & $0.8-1.0$ & $\begin{array}{l}\mathrm{LiOH} . \mathrm{H}_{2} \mathrm{O} \\
\mathrm{Li}_{2} \mathrm{CO}_{3}\end{array}$ & 0.9 \\
\hline & & $\begin{array}{l}\text { Andesite } \\
\text { sand }\end{array}$ & & 1.2 & $\mathrm{LiOH} . \mathrm{H}_{2} \mathrm{O}$ & 0.9 \\
\hline Stark & ASTM C 227 & Andesite & & & $\mathrm{LiF}, \mathrm{Li}_{2} \mathrm{CO}_{3}$ & $0.67(\mathrm{LiF}), 0.92\left(\mathrm{Li}_{2} \mathrm{CO}_{3}\right)$ \\
\hline Stark et al. & $\begin{array}{l}\text { ASTM C } \quad P \\
214\end{array}$ & $\begin{array}{l}\text { Rhyolite } \\
\text { Granite } \\
\text { gneiss }\end{array}$ & & & $\mathrm{LiOH} . \mathrm{H}_{2} \mathrm{O}$ & $0.75-1.0(\mathrm{LiOH})$ \\
\hline \multirow{2}{*}{$\begin{array}{l}\text { Diamond } \\
\text { and Ong }\end{array}$} & ASTM C 227 & Cristobalite & 0.485 & 1 & $\mathrm{LiOH}$ & \multirow{2}{*}{$\begin{array}{l}1.2 \text { (Cristobalite, more for } \\
\text { opal) }\end{array}$} \\
\hline & & Beltane opal & 0.485 & 1 & $\mathrm{LiOH}$ & \\
\hline Durand & ASTM C 1293 & $\begin{array}{l}\text { Sudbury } \\
\text { Potsdam } \\
\text { Sherbrooke }\end{array}$ & 0.405 & $\begin{array}{l}0.88- \\
1.25\end{array}$ & $\begin{array}{l}\mathrm{LiOH} . \mathrm{H}_{2} \mathrm{O}, \mathrm{LiF}, \mathrm{Li}_{2} \mathrm{CO}_{3} \\
\mathrm{LiNO}_{3}\end{array}$ & $\begin{array}{l}\text { With Sudbury: } 0.72 \text { for } \\
\mathrm{LiNO}_{3} 0.82 \text { for other three }\end{array}$ \\
\hline \multirow[t]{2}{*}{ Lane } & ASTM C 1260 & Pyrex glass & 0.45 & $\begin{array}{l}0.75- \\
1.25\end{array}$ & $\mathrm{LiOH} . \mathrm{H}_{2} \mathrm{O}, \mathrm{LiNO}_{3}$ & 0.925 for $\mathrm{LiNO}_{3}$ \\
\hline & ASTM C 1293 & Quartz & & & & \\
\hline Lumley & ASTM C 1293 & Cristobalite & 0.5 & $\begin{array}{l}0.86- \\
1.13\end{array}$ & $\mathrm{LiOH} . \mathrm{H}_{2} \mathrm{O}, \mathrm{LiF}, \mathrm{Li}_{2} \mathrm{CO}_{3}$ & 0.62 \\
\hline $\begin{array}{l}\text { Thomas et } \\
\text { al. }\end{array}$ & ASTM C 1293 & $\begin{array}{l}\text { UK } \\
\text { aggregates }\end{array}$ & & & $\mathrm{LiOH} . \mathrm{H}_{2} \mathrm{O}, \mathrm{LiNO}_{3}$ & $\begin{array}{l}0.74 \text { for } \mathrm{LiNO}_{3} \\
0.85 \text { for } \mathrm{LiOH} . \mathrm{H}_{2} \mathrm{O}\end{array}$ \\
\hline $\begin{array}{l}\text { Collins et } \\
\text { al. }\end{array}$ & ASTM C 227 & $\begin{array}{l}\text { Borosilicate } \\
\text { glass }\end{array}$ & 0.37 & 1 & $\mathrm{LiOH}, \mathrm{LiCl}, \mathrm{LiNO}_{3}$ & $\begin{array}{l}0.6 \text { for } \mathrm{LiOH}, 0.9 \text { for } \mathrm{LiCl} 0.8 \\
\text { for } \mathrm{LiNO}_{3}\end{array}$ \\
\hline $\begin{array}{l}\text { Kawamura } \\
\text { et al. }\end{array}$ & ASTM C 227 & $\begin{array}{l}\text { Calcined } \\
\text { flint }\end{array}$ & 0.55 & 1.12 & $\mathrm{LiOH}, \mathrm{Li}_{2} \mathrm{CO}_{3}$ & $0.75 \mathrm{M}$ \\
\hline Berra et al. & ASTM C 1293 & $\begin{array}{l}\text { Siliceous } \\
\text { aggregate }\end{array}$ & 0.44 & $\begin{array}{l}2.3-9 \\
\mathrm{~kg} / \mathrm{m}^{3}\end{array}$ & $\mathrm{LiNO}_{3}, \mathrm{Li}_{2} \mathrm{CO}_{3}$ & \\
\hline $\begin{array}{l}\text { Ohama et } \\
\text { al. }\end{array}$ & Autoclave & $\begin{array}{l}\text { Opaline } \\
\text { amorphous } \\
\text { silica }\end{array}$ & $\begin{array}{l}0.63- \\
0.78\end{array}$ & 2 & $\begin{array}{ll}\mathrm{LiOH} . & \mathrm{H}_{2} \mathrm{O}, \\
\mathrm{LiF}, \mathrm{Li}_{2} \mathrm{CO}_{3} & \end{array}$ & $\begin{array}{l}0.5 \% \text { wt for } \mathrm{LiF} \\
0.7 \% \text { wt for } \mathrm{LiOH} . \mathrm{H}_{2} \mathrm{O}\end{array}$ \\
\hline Bian et al. & Autoclave & $\begin{array}{l}\text { Andesite } \\
\text { sand }\end{array}$ & 0.5 & $0.5-3.5$ & $\begin{array}{l}\mathrm{LiF}, \mathrm{LiCl}, \mathrm{LiBr} . \mathrm{LiNO}_{3}, \mathrm{LiOH} \\
\mathrm{Li}_{2} \mathrm{SO}_{4}, \mathrm{Li}_{2} \mathrm{CO}_{3}, \mathrm{LiH}_{2} \mathrm{PO}_{4}\end{array}$ & 0.8 \\
\hline Mo et al. & Autoclave & $\begin{array}{l}\text { Microcrystallin } \\
\text { e Quartzo }\end{array}$ & & $1.5-3$ & $\mathrm{LiOH} . \mathrm{H}_{2} \mathrm{O}$ & $\begin{array}{l}\geq 0.3 \quad \text { for } \quad \mathrm{Na}_{2} \mathrm{Oe} \leq 2.5 \% \\
\geq 0.6 \text { for } \mathrm{Na}_{2} \mathrm{Oe}=3 \%\end{array}$ \\
\hline
\end{tabular}

(Feng et al. 2005) 


\section{PROGRAMA EXPERIMENTAL}

\subsection{Materiais Selecionados}

\section{Agregados}

\section{Granito Milonítico}

- Para a realização do programa experimental foi selecionada uma amostra de agregado potencialmente reativo com os álcalis, proveniente da Região do Grande Recife/PE. Em 2005 foram identificados os primeiros casos de RAA em fundações de obras de edificações, inédito para o meio técnico nacional e internacional.

\section{Basalto}

- O agregado do tipo litológico basalto foi escolhido por ser considerado potencialmente reativo com os álcalis. Rochas basálticas são típicas das regiões Sul e Sudeste e amplamente utilizadas no preparo de concreto destinado a obras correntes e de infra-estrutura, como nas usinas hidroelétricas.

\section{Adições Ativas}

\section{Escória de Alto-forno}

- A escória de alto-forno empregada na pesquisa foi produzida pela Companhia Siderúrgica Nacional (CSN) e é representativa da normalmente empregada pela indústria do cimento no Brasil nos cimentos CP II-E e CP III.

\section{Cinza Volante}

- A cinza volante empregada é procedente do pólo Petroquímico do Sul e foi produzida pela Companhia Petroquímica do Sul - COPESUL, instalada em Triunfo/RS. A cinza volante é equivalente à normalmente adicionada aos cimentos CP II-Z e CP IV produzidos na Região Sul. 


\section{Metacaulim}

- O metacaulim utilizado provém da empresa de beneficiamento de minerais não-metálicos Caulim do Nordeste S/A, localizada em Ipojuca/PE, e é similar ao normalmente adicionado aos concretos de cimento Portland.

\section{Sílica Ativa}

- A sílica ativa Silmix empregada na pesquisa foi fornecida pela Tecnosil e é representativa da normalmente adicionada aos concretos de cimento Portland.

\section{Cimento Portland}

\section{CP V-ARI}

- Constituído essencialmente por clínquer e sulfato de cálcio, comprovadamente não-mitigador da reação álcali-agregado, apresenta expansão em autoclave inferior a 0,20\%, conforme prescreve o método de ensaio ASTM C 1260.

\section{Cimentos Preparados em Laboratório}

- Foram preparados em laboratório quinze cimentos experimentais, substituindo-se, em massa, o CP V-ARI pelas adições ativas:

- quatro cimentos compostos (dois CP II-E com 15\% e $30 \%$ de escória de alto-forno, e dois CP II-Z com 10\% e 15\% de cinza volante);

- dois cimentos de alto-forno - CP III com 45\% e 60\% de escória de alto-forno;

- dois cimentos pozolânicos - CP IV com 25\% e 35\% de cinza volante;

- quatro cimentos com adição de metacaulim com teores de 5\%; $10 \% ; 15 \%$ e $20 \%$;

- três cimentos com adição de sílica ativa nos teores de 5\%; 10\% e $15 \%$. 
- Os cimentos Portland compostos, pozolânicos e de alto-forno são produzidos industrialmente a partir das adições ativas de escória de altoforno e cinza volante. A escolha dessas adições bem como os teores presentes nos cimentos produzidos em laboratório foram definidos visando representatividade dos normalmente comercializados no mercado brasileiro.

- As adições de metacaulim e sílica ativa foram escolhidas por serem as únicas adições ativas normalizadas que podem ser adicionadas ao concreto, segundo a norma NBR 12655. Os teores escolhidos abrangem a faixa comumente adicionada nos concretos de cimento Portland.

A Figura 14 ilustra a composição dos aglomerantes empregados.

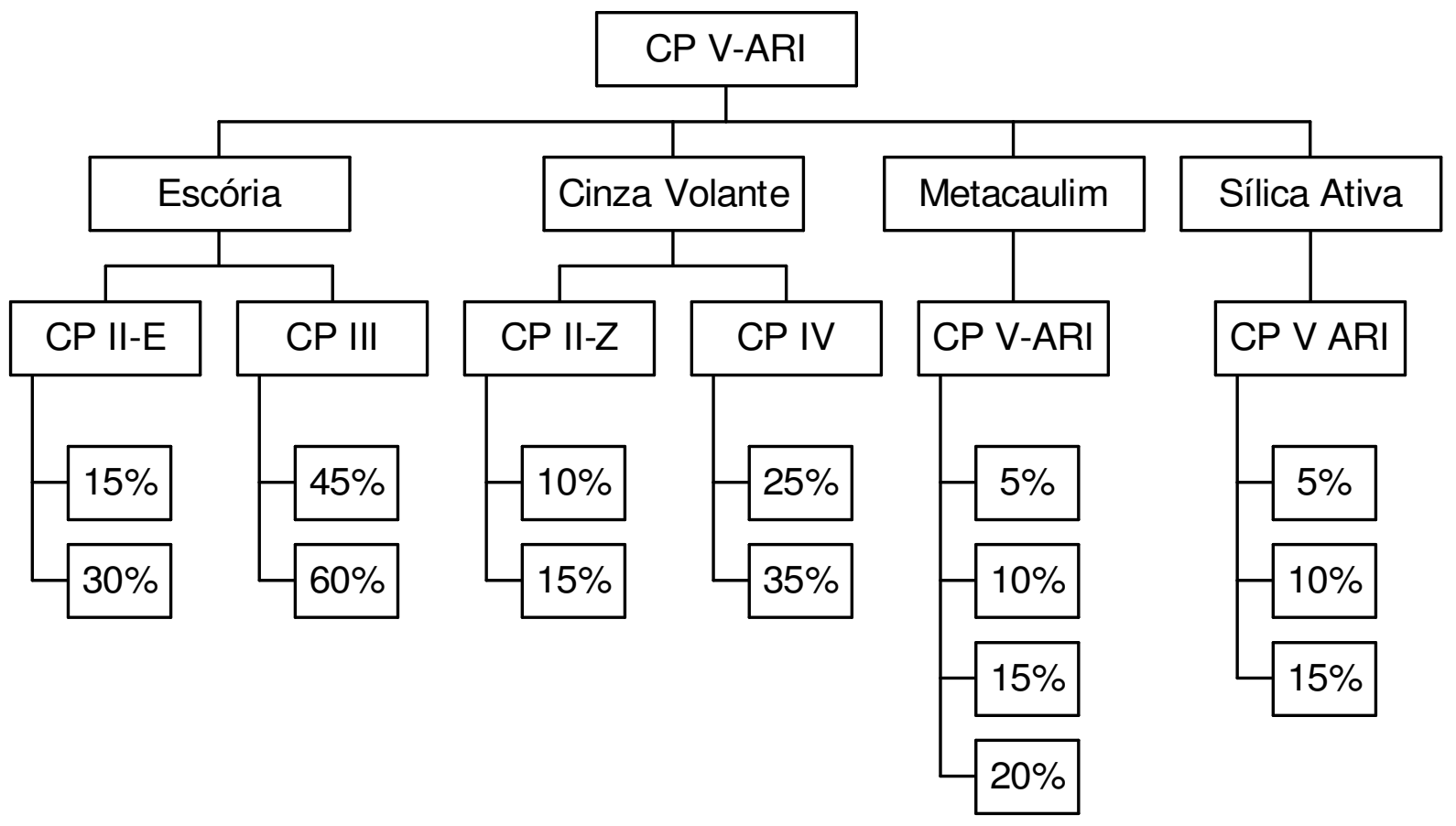

Figura 14 - Resumo da composição dos aglomerantes empregados

\subsection{Metodologia de Caracterização dos Materiais}

Os materiais empregados na pesquisa foram submetidos aos ensaios de caracterização química, física, mecânica e mineralógica, conforme apresentado na

Figura 15. Adicionalmente, determinou-se o índice de atividade pozolânica com cal das amostras de agregado milonito granítico e basalto com objetivo de avaliar se o material apresenta alguma aptidão à reação com hidróxido de cálcio. 


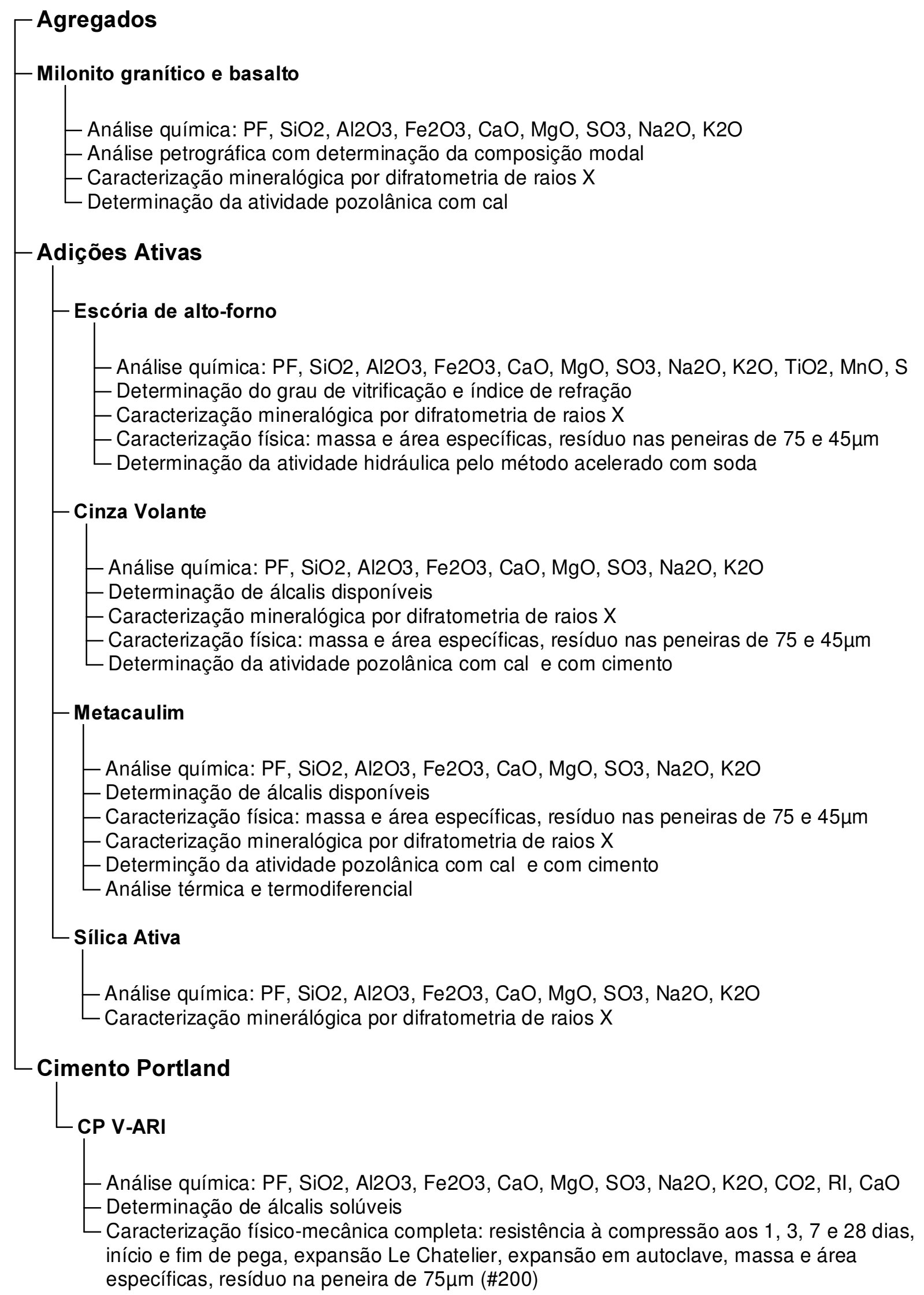

Figura 15 - Resumo dos ensaios de caracterização dos materiais selecionados 


\subsection{Determinação da Reatividade dos Agregados (ASTM C 1260)}

O método da ASTM C 1260-05a é um dos mais utilizados para avaliar a reatividade de agregados frente a uma solução alcalina de hidróxido de sódio, através do monitoramento da expansão dimensional de barras de argamassa.

Para o preparo da argamassa o agregado deve ser processado com um mínimo de britagem, quando necessário, de forma a produzir um produto classificado conforme a Tabela 7. Após o agregado ter sido classificado, cada fração é lavada com água corrente para remover o pó aderido e partículas finas do agregado. As frações retidas nas várias peneiras são secadas e cada fração, armazenada individualmente em recipiente limpo e fechado.

Tabela 7 - Granulometria requerida do agregado para ensaio acelerado

\begin{tabular}{cccc}
\hline $\begin{array}{c}\text { Peneira com abertura de malha } \\
\text { (NBR NM ISO 3310-1) }\end{array}$ & Quantidade de material em massa \\
\hline Passante & Retido & Porcentagem & Gramas \\
\hline $4,75 \mathrm{~mm}$ & $2,36 \mathrm{~mm}$ & 10 & 99,0 \\
\hline $2,36 \mathrm{~mm}$ & $1,18 \mathrm{~mm}$ & 25 & 247,5 \\
\hline $1,18 \mathrm{~mm}$ & $600 \mu \mathrm{m}$ & 25 & 247,5 \\
\hline $600 \mu \mathrm{m}$ & $300 \mu \mathrm{m}$ & 25 & 247,5 \\
\hline $300 \mu \mathrm{m}$ & $150 \mu \mathrm{m}$ & 15 & 148,5 \\
\hline
\end{tabular}

Segundo esse método, as barras são moldadas com proporção cimento:agregado de 1:2,25 com relação a/c fixa igual a 0,47 com um cimento comprovadamente nãomitigador da RAA e com expansão em autoclave inferior a $0,2 \%$.

Após 24 horas da adição da água, as barras são desformadas e colocadas em recipiente para cura em água, o qual é gradualmente aquecido desde a temperatura ambiente até atingir ( $80 \pm 2)^{\circ} \mathrm{C}$. As barras são conservadas nessa condição por $24 \mathrm{~h}$. Após esse período de estabilização, as barras são removidas do recipiente de cura, uma de cada vez, e rapidamente medidos os seus comprimentos em sala climatizada a $(23 \pm 2)^{\circ} \mathrm{C}$, de modo a registrar a leitura inicial a $80^{\circ} \mathrm{C}$. 
Cada medida, com precisão de 0,002mm, deve ser feita dentro de $15 \pm 5$ segundos com o objetivo de não resfriar significativamente a argamassa, conforme preconiza o método.

Após a leitura inicial, as barras são colocadas em cura em solução aquosa de $\mathrm{NaOH}$ $1 \mathrm{~N}$ a $(80 \pm 2)^{\circ} \mathrm{C}$, sendo medidos seus comprimentos periodicamente por, no mínimo, 14 dias, e calculada a expansão linear.

A metodologia estabelece que a expansão média de três prismas deve ser calculada pelo menos por três idades intermediárias antes dos 14 dias de cura agressiva, sendo que a repetibilidade é considerada satisfatória quando dois resultados dentro do mesmo laboratório, com os mesmos operadores e agregados, não diferirem mais que $8,3 \%$ da expansão média para valores acima de $0,10 \%$ aos 14 dias de cura agressiva.

Segundo a norma, os resultados devem ser expressos pela média de leituras de três barras, sendo os valores individuais com aproximação de 0,001\% e a média, com aproximação de 0,01\%.

\subsection{Determinação da Eficiência dos Cimentos com Adições Ativas em Mitigar a RAA (ASTM C 1567)}

O método preconizado pela ASTM C 1567 (2004), com o mesmo princípio do método da ASTM C 1260, é indicado para avaliar a eficiência de cimentos com adições de escória de alto-forno, materiais pozolânicos, metacaulim ou sílica ativa, em mitigar a expansão decorrente da reação álcali-agregado. Quando é adicionada sílica ativa ou metacaulim ao cimento, deverá ser usado, se necessário, um aditivo superplastificante de forma a manter a consistência das argamassas em $\pm 7,5 \%$ daquela obtida na argamassa de referência, sem adição. 
A Figura 16 ilustra os ensaios realizados para determinação da expansão em barras de argamassa pelo método acelerado.

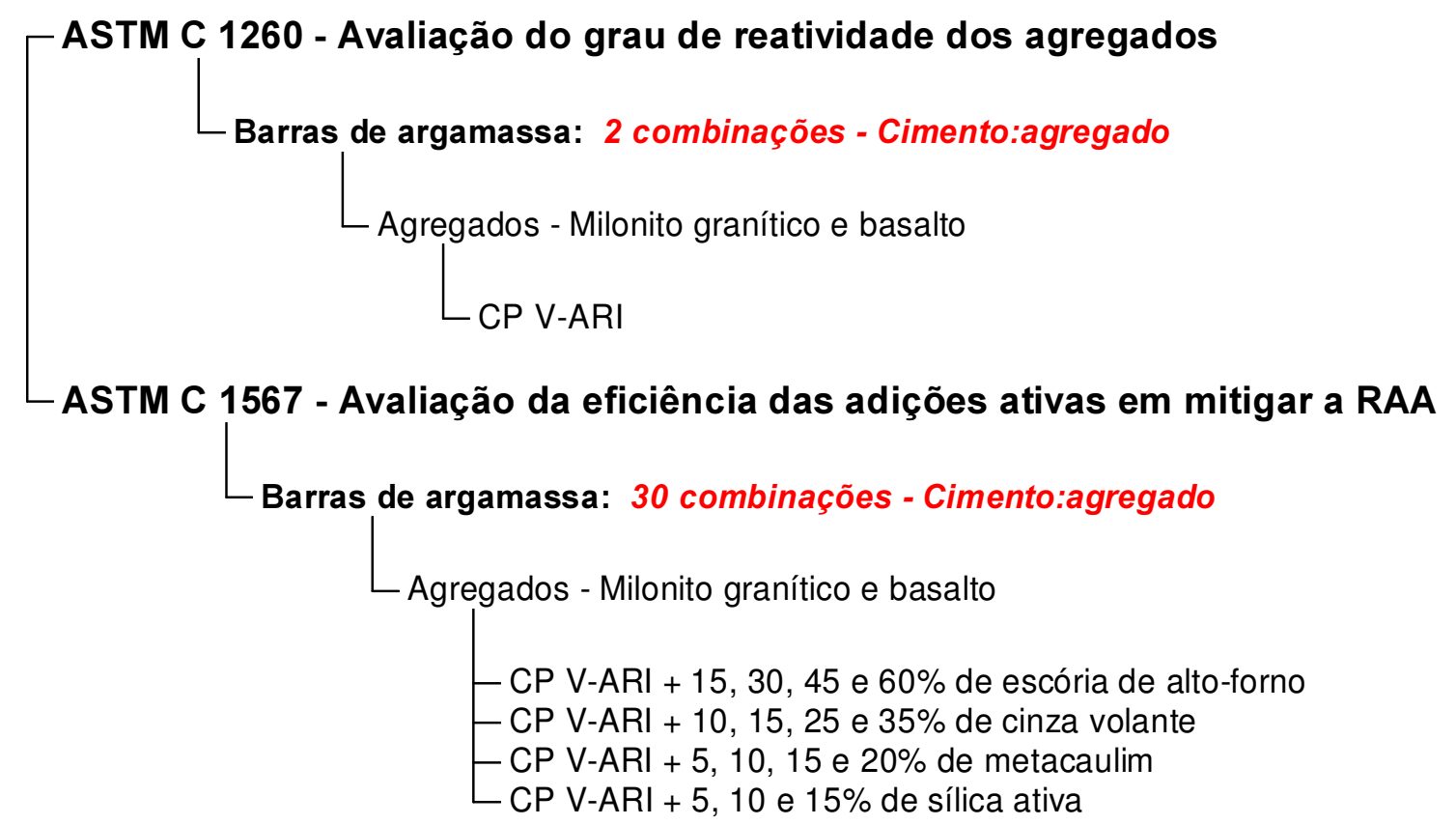

Figura 16 - Resumo dos ensaios de determinação da expansão em barras de argamassa pelos métodos acelerado

\subsection{Caracterização das Barras de Argamassa}

Após a realização dos ensaios acelerados em solução alcalina $1 \mathrm{~N}$ a $80^{\circ} \mathrm{C}$ durante 28 dias as barras de argamassa foram caracterizadas como segue:

\section{> Determinação das Resistências Mecânicas}

Os ensaios de tração na flexão e à compressão foram realizados nas barras de argamassa para avaliar os efeitos das adições no desempenho mecânico. 


\section{> Determinação do Teor de Álcalis Solúveis}

Foram determinados os teores de álcalis solúveis $\left(\mathrm{Na}_{2} \mathrm{O}\right.$ e $\left.\mathrm{K}_{2} \mathrm{O}\right)$ das barras de argamassa com o objetivo de quantificar a migração de íons alcalinos da solução de $\mathrm{NaOH} 1 \mathrm{~N}$ e avaliar a influência das adições na permeabilidade.

\section{> Análises Térmica Diferencial e Termogravimétrica}

As análises térmicas foram realizadas com o objetivo de determinar o teor de hidróxido de cálcio $\left(\mathrm{Ca}(\mathrm{OH})_{2}\right)$ nas barras de argamassa e correlacioná-lo com a redução da expansão.

\section{> Análise da Microtextura - Microscopia Estereoscópica e Eletrônica de Varredura}

Após a realização dos ensaios acelerados, as barras de argamassa foram analisadas ao microscópio estereoscópico, ao microscópio óptico de luz transmitida e ao microscópio eletrônico de varredura com espectrômetro de energia dispersiva, para avaliar a formação de gel, a morfologia dos produtos de reação, visando compreender os efeitos da minimização da reação álcali-agregado quando da utilização de adições ativas.

\section{$>$ Porosimetria por Intrusão de Mercúrio}

As análises foram realizadas com o objetivo de determinar a porosidade e avaliar a influência das adições ativas no refinamento do tamanho dos poros de forma a contribuir para a redução da permeabilidade. 
A Figura 17 ilustra os ensaios de caracterização das barras de argamassa após a realização dos ensaios acelerados.

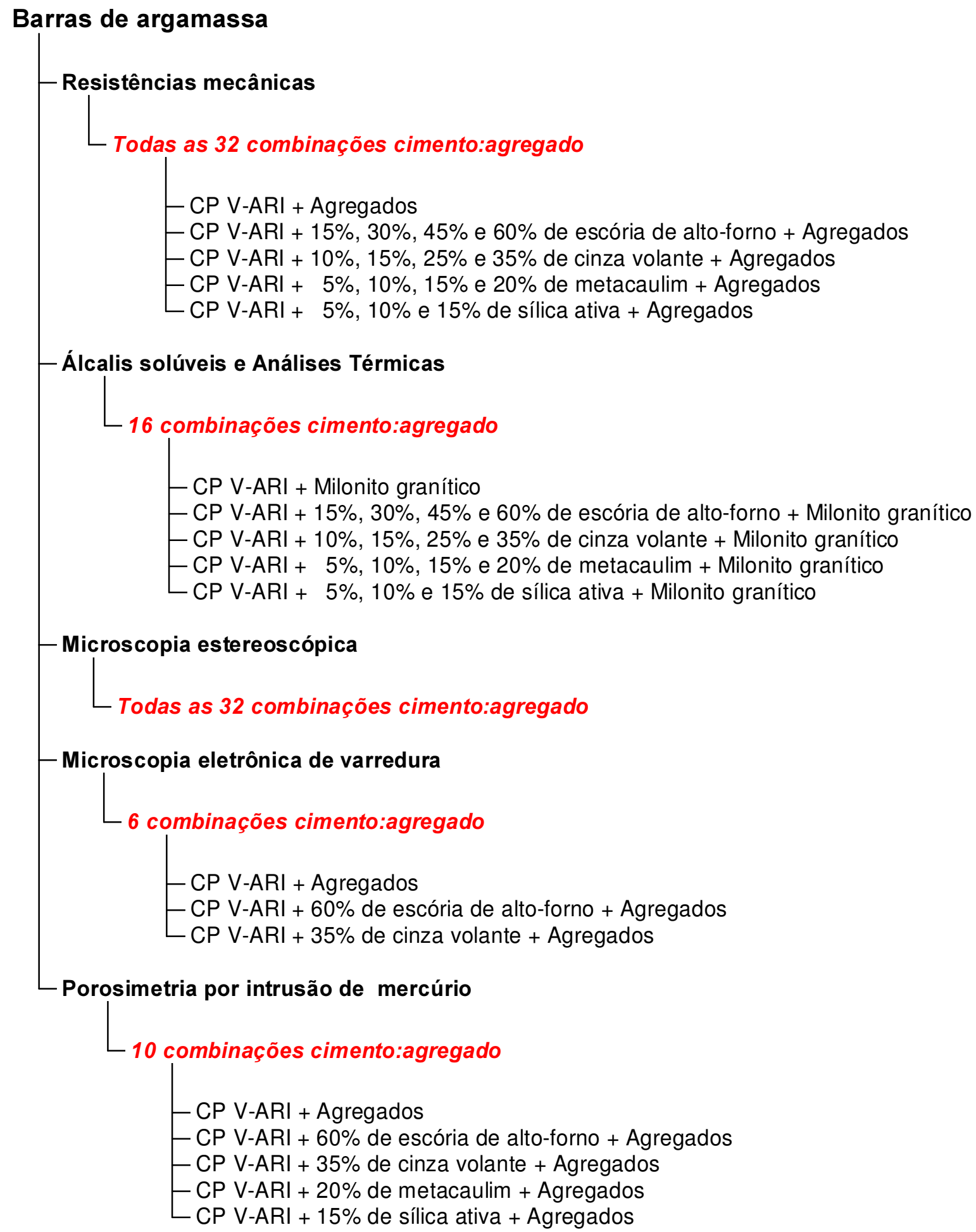

Figura 17 - Resumo dos ensaios de caracterização das barras de argamassa 


\section{RESULTADOS DA CARACTERIZAÇÃO DOS MATERIAIS}

Os materiais empregados na pesquisa foram submetidos aos ensaios de caracterização química, física, mecânica e mineralógica. Os resultados detalhados das análises realizadas bem como os métodos analíticos empregados estão apresentados nos Apêndices A e B.

Uma síntese das caracterizações é apresentada a seguir.

\subsection{Composição Química dos Aglomerantes}

A Tabela 8 apresenta a análise química do cimento e das adições ativas empregados na pesquisa.

Tabela 8 - Resultados percentuais da composição química do cimento e das adições ativas

\begin{tabular}{|c|c|c|c|c|c|}
\hline \multirow{3}{*}{ Ensaios } & \multicolumn{5}{|c|}{ Resultados (\% em massa) } \\
\hline & \multirow{2}{*}{$\begin{array}{l}\text { Cimento } \\
\text { CP V-ARI }\end{array}$} & \multicolumn{4}{|c|}{ Adições ativas } \\
\hline & & $\begin{array}{l}\text { Escória de } \\
\text { alto-forno }\end{array}$ & $\begin{array}{c}\text { Cinza } \\
\text { volante }\end{array}$ & Metacaulim & $\begin{array}{l}\text { Sílica } \\
\text { ativa }\end{array}$ \\
\hline Perda ao fogo - PF & 2,45 & 0,00 & 1,31 & 1,99 & 3,15 \\
\hline Dióxido de silício - $\mathrm{SiO}_{2}$ & 19,21 & 35,03 & 66,39 & 49,92 & 91,56 \\
\hline Óxido de alumínio - $\mathrm{Al}_{2} \mathrm{O}_{3}$ & 4,97 & 11,07 & 18,68 & 41,39 & 0,09 \\
\hline Óxido de ferro $-\mathrm{Fe}_{2} \mathrm{O}_{3}$ & 2,89 & 1,96 & 5,87 & 3,83 & 0,30 \\
\hline Óxido de cálcio - $\mathrm{CaO}$ & 64,52 & 44,70 & 2,64 & 0,69 & 0,85 \\
\hline Óxido de magnésio - MgO & 0,50 & 4,84 & 2,89 & 1,85 & 0,25 \\
\hline Anidrido sulfúrico $-\mathrm{SO}_{3}$ & 2,92 & - & 0,12 & 0,09 & 0,26 \\
\hline Óxido de sódio - $\mathrm{Na}_{2} \mathrm{O}$ & 0,26 & 0,10 & 0,15 & 0,03 & 0,05 \\
\hline Óxido de potássio - $\mathrm{K}_{2} \mathrm{O}$ & 0,90 & 0,31 & 1,85 & 0,20 & 2,40 \\
\hline Anidrido carbônico - $\mathrm{CO}_{2}$ & 1,22 & - & - & - & - \\
\hline Resíduo insolúvel - RI & 0,86 & - & - & - & - \\
\hline Óxido de cálcio livre $\mathrm{CaO}$ (livre) & 1,71 & - & - & - & - \\
\hline Equivalente alcalino total- $\mathrm{Na}_{2} \mathrm{O}_{e}$ & 0,85 & 0,30 & 1,34 & 0,16 & 1,63 \\
\hline Óxido de sódio disponível - $\mathrm{Na}_{2} \mathrm{O}$ & - & 0,001 & 0,000 & 0,000 & 0,001 \\
\hline $\begin{array}{l}\text { Óxido de potássio disponível - } \\
\mathrm{K}_{2} \mathrm{O}\end{array}$ & - & 0,002 & 0,005 & 0,002 & 0,003 \\
\hline
\end{tabular}


Os resultados apresentados revelaram que os materiais são constituídos principalmente por $\mathrm{SiO}_{2}, \mathrm{Al}_{2} \mathrm{O}_{3}, \mathrm{Fe}_{2} \mathrm{O}_{3}, \mathrm{CaO}, \mathrm{MgO}$, que, somados, totalizam mais de $90 \%$ da composição química.

O cimento Portland de alta resistência inicial atende a todos os requisitos químicos especificados na NBR 5733/91. A escória de alto-forno é básica e atende às especificações da NBR 5735/91. A cinza volante e o metacaulim atendem a todas as exigências químicas da NBR $12653 / 92$ para materiais pozolânicos classe C (cinza volante) e para materiais pozolânicos classe $\mathrm{N}$ (pozolanas naturais e artificiais), respectivamente. A sílica ativa apresentou teor de equivalente alcalino em $\mathrm{Na}_{2} \mathrm{O}$ superior ao especificado na NBR 13956/97, que deve ser $\leq 1,5 \%$. O teor de álcalis disponíveis em $\mathrm{Na}_{2} \mathrm{O}_{e}$ das adições ativas determinado pela NBR NM 25/02 é inferior a 0,005\%.

\subsection{Composição Mineralógica dos Aglomerantes}

Cimento Portland de alta resistência inicial $\rightarrow$ constituído essencialmente por clínquer Portland e sulfato de cálcio. O teor de fíler calcário, calculado com base no teor de anidrido carbônico $\left(\mathrm{CO}_{2}\right)$ da calcita, foi de 2,8\%.

Escória de alto-forno $\rightarrow$ constituída essencialmente por grãos irregulares e vítreos, representados pelo halo de amorfização entre $2 \theta=20^{\circ}$. e $40^{\circ}$. O grau de vitrificação da escória, determinado por microscopia óptica de luz transmitida, é de 90\%. Gelenita $\left(\mathrm{Ca}_{2} \mathrm{Al}_{2} \mathrm{SiO}_{7}\right)$, merwinita $\left(\mathrm{Ca}_{3} \mathrm{Mg}\left(\mathrm{SiO}_{4}\right)_{2}\right)$ e quartzo $\left(\mathrm{SiO}_{2}\right)$ são os minerais cristalizados, que, somados, representam $10 \%$ da composição da escória de altoforno.

Cinza volante $\rightarrow$ constituída mineralogicamente pelos minerais cristalizados quartzo $\left(\mathrm{SiO}_{2}\right)$ e mulita $\left(3 \mathrm{Al}_{2} \mathrm{O}_{3} \cdot 2 \mathrm{SiO}_{2}\right)$. Observa-se no difratograma halo de amorfização entre $2 \theta=15^{\circ}$ e $30^{\circ}$, correspondente à fase vítrea (amorfa) da cinza volante.

Metacaulim $\rightarrow$ constituído essencialmente por metacaulinita, representada no difratograma pelo halo de amorfização entre $2 \theta=15^{\circ}$ e $30^{\circ}$, indicando que 0 
processo de calcinação da matéria-prima foi eficiente. Quartzo $\left(\mathrm{SiO}_{2}\right)$ e hematita $\left(\mathrm{Fe}_{2} \mathrm{O}_{3}\right)$ estão presentes em teores pouco significativos.

Sílica ativa $\rightarrow$ constituída essencialmente por material amorfo, representado no difratograma pelo halo de amorfização entre $2 \theta=15^{\circ}$ e $30^{\circ}$. Identificou-se também quartzo $\left(\mathrm{SiO}_{2}\right)$.

\subsection{Caracterização Físico-Mecânica dos Aglomerantes}

A Tabela 9 apresenta as características físicas e o desempenho dos aglomerantes.

Tabela 9 - Características físicas e desempenho dos aglomerantes

\begin{tabular}{|c|c|c|c|c|c|}
\hline \multirow[b]{2}{*}{ Ensaios } & \multirow{2}{*}{$\frac{\text { Cimento }}{\text { CP V-ARI }}$} & \multicolumn{4}{|c|}{ Adições } \\
\hline & & Escória & $\begin{array}{l}\text { Cinza } \\
\text { volante }\end{array}$ & Metacaulim & Sílica ativa \\
\hline $\begin{array}{l}\text { Finura - resíduo na peneira de } \\
75 \mu \mathrm{m}(\%)\end{array}$ & 0,2 & 0,2 & 1,2 & 0,2 & - \\
\hline $\begin{array}{l}\text { Massa específica } \\
\left(\mathrm{g} / \mathrm{cm}^{3}\right)\end{array}$ & 3,10 & 2,94 & 2,21 & 2,56 & 2,69 \\
\hline $\begin{array}{l}\text { Área específica - Blaine } \\
\left(\mathrm{cm}^{2} / \mathrm{g}\right)\end{array}$ & 4400 & 4160 & 4680 & 23430 & - \\
\hline $\begin{array}{l}\text { Atividade pozolânica com cal } \\
\text { (MPa) }\end{array}$ & - & - & 8,8 & 14,0 & \\
\hline $\begin{array}{l}\text { Atividade pozolânica com } \\
\text { cimento (\%) }\end{array}$ & - & - & 98,9 & 89,7 & - \\
\hline $\begin{array}{l}\text { Porcentagem de água requerida } \\
(\%)\end{array}$ & - & - & 100,0 & 128,6 & - \\
\hline $\begin{array}{l}\text { Atividade hidráulica com } \\
\text { hidróxido de sódio a } 23^{\circ} \mathrm{C}(\mathrm{MPa})\end{array}$ & - & 11,0 & - & - & - \\
\hline $\begin{array}{l}\text { Atividade hidráulica com } \\
\text { hidróxido de sódio a } 55^{\circ} \mathrm{C}(\mathrm{MPa})\end{array}$ & - & 17,9 & - & - & - \\
\hline $\begin{array}{l}\text { Expansibilidade em autoclave } \\
\text { (\%) }\end{array}$ & 0,10 & - & - & - & - \\
\hline
\end{tabular}

A amostra de cimento Portland de alta resistência inicial (CP V-ARI) apresentou expansão em autoclave de $0,10 \%$, quando ensaiada pela ASTM C 151, atendendo à especificação da ASTM C 1260, que prescreve expansão inferior a $0,20 \%$. 
O índice de atividade pozolânica com cal especificado pela NBR 12653/92 Materiais Pozolânicos - Especificação deve ser de, no mínimo, 6,0 MPa de resistência à compressão aos 7 dias.

As amostras de cinza volante e metacaulim apresentaram índices de $8,8 \mathrm{MPa}$ e $14,0 \mathrm{MPa}$, respectivamente, atendendo à especificação da norma.

O índice de atividade pozolânica com cimento Portland especificado pela NBR 12653/92 Materiais Pozolânicos - Especificação deve ser de, no mínimo, 75\%. A porcentagem máxima de água requerida para as pozolanas de classe $\mathrm{C}$ (cinza volante) é de $110 \%$, e para as de classe N (argilas calcinadas), 115\%.

As amostras de cinza volante e metacaulim apresentaram índices de 98,9\% e $89,7 \%$, respectivamente, atendendo à especificação da norma. Com relação à porcentagem máxima de água requerida, a cinza volante atende ao parâmetro da norma, mas o metacaulim ficou acima $(128,6 \%)$ do valor especificado para as pozolanas de classe $\mathrm{N}$, provavelmente devido à finura, o que pode ter contribuído para o desempenho inferior ao apresentado pela cinza volante.

No ensaio de atividade hidráulica com hidróxido de sódio em cura normal (23ํㅡ a $48 \mathrm{~h}$ ), os valores de resistência típicos de escórias de alto-forno de boa qualidade são de $7 \mathrm{MPa}$ a $10 \mathrm{MPa}$. Em cura acelerada (55ㄷ $\mathrm{C}$ a $24 \mathrm{~h}$ ), esses valores aumentam em geral para $13 \mathrm{MPa}$ a $15 \mathrm{MPa}$. Esses valores de referência são válidos para áreas específicas próximas de $3500 \mathrm{~cm}^{2} / \mathrm{g}$.

A escória de alto-forno analisada apresentou resistências em cura normal e acelerada acima dos valores de referência mencionados devido à maior finura. Com base nos resultados obtidos, conclui-se que a amostra de escória de alto-forno é de boa qualidade e representativa das escórias normalmente adicionadas aos cimentos brasileiros. 


\subsection{Caracterização dos Agregados}

\section{$>$ Caracterização química dos agregados}

A Tabela 10 apresenta a caracterização química dos agregados milonito granítico e basalto.

Tabela 10 - Composição química dos agregados

\begin{tabular}{lcc}
\hline \multirow{2}{*}{ Ensaios } & \multicolumn{2}{c}{ Resultados (\% em massa) } \\
\cline { 2 - 3 } & $\begin{array}{c}\text { Milonito } \\
\text { granítico }\end{array}$ & Basalto \\
\hline Perda ao fogo - PF & $\mathbf{0 , 9 4}$ & $\mathbf{1 , 6 0}$ \\
\hline Dióxido de silício $-\mathrm{SiO}_{2}$ & $\mathbf{6 9 , 3 7}$ & $\mathbf{5 0 , 0 3}$ \\
\hline Óxido de alumínio $-\mathrm{Al}_{2} \mathrm{O}_{3}$ & $\mathbf{1 0 , 3 8}$ & $\mathbf{1 1 , 7 4}$ \\
\hline Óxido de ferro $-\mathrm{Fe}_{2} \mathrm{O}_{3}$ & $\mathbf{2 , 7 3}$ & $\mathbf{1 5 , 3 9}$ \\
\hline Óxido de cálcio $-\mathrm{CaO}$ & 3,45 & $\mathbf{1 1 , 4 7}$ \\
\hline Óxido de magnésio $-\mathrm{MgO}$ & $\mathbf{5 , 1 6}$ & $\mathbf{5 , 9 9}$ \\
\hline Anidrido sulfúrico $-\mathrm{SO}_{3}$ & $\mathbf{0 , 1 3}$ & $\mathbf{0 , 0 2}$ \\
\hline Óxido de sódio $-\mathrm{Na}_{2} \mathrm{O}$ & $\mathbf{3 , 9 2}$ & $\mathbf{1 , 9 0}$ \\
\hline Óxido de potássio $-\mathrm{K}_{2} \mathrm{O}$ & $\mathbf{3 , 6 5}$ & $\mathbf{0 , 8 0}$ \\
\hline
\end{tabular}

\section{$>$ Análise petrográfica do milonito granítico}

Os ensaios de caracterização tecnológica da amostra de agregado procedente da Região do Grande Recife/PE revelaram que a rocha é classificada como milonito granítico (álcali feldspato granito protomilonítico).

A caracterização petrográfica indica que a rocha foi submetida a processos tectônicos que levaram à deformação e cisalhamento da textura da rocha, modificando a estrutura cristalina dos silicatos, ocasionando um aumento de entropia. A presença de cristais de quartzo microgranulares e freqüentemente recristalizados associados aos cristais de feldspatos e quartzo deformados, esse último, com extinção ondulante, indicam uma susceptibilidade à reação com os álcalis do concreto. A Tabela 11 sintetiza as principais características do agregado milonito granítico. 
Tabela 11 - Síntese das principais características petrográficas da amostra de milonito granítico

\begin{tabular}{lll}
\hline & Principal & $\begin{array}{l}\text { Quartzo }(22,0 \%), \text { feldspato (microclínio e plagioclásio) }(60,6 \%), \\
\text { mica (biotita e muscovita) }(13,0 \%)\end{array}$ \\
\cline { 2 - 3 } Mineralogia & Subordinada & $\begin{array}{l}\text { Allanita }(0,5 \%) \text {, opacos }(0,9 \%), \text { apatita }(0,3 \%), \text { titanita }(0,5 \%), \\
\text { zircão (traço), carbonato }(0,7 \%), \text { epídoto }(1,1 \%) \text { e clorita }(0,2 \%), \\
\text { hidróxidos de ferro }(0,2 \%)\end{array}$ \\
\cline { 2 - 3 } Cor & Quartzo microgranular e quartzo e feldspato deformados \\
\hline Estrutura & Cinza a cinza rosado \\
\hline Textura & Foliada \\
\hline Granulação & Milonítica \\
\hline Estado de alteração & Média \\
\hline Deformação do agregado & Leve a moderada \\
\hline Propriedade físico-mecânica & Dochormado muito coerente \\
\hline Forma dos fragmentos & Equidimensionais a lamelares \\
\hline Tipo de rocha & Metamórfica \\
\hline Classificação petrográfica & Milonito granítico (álcali feldspato granito protomilonitico) \\
\hline Reatividade potencial & Potencialmente reativa \\
\hline
\end{tabular}

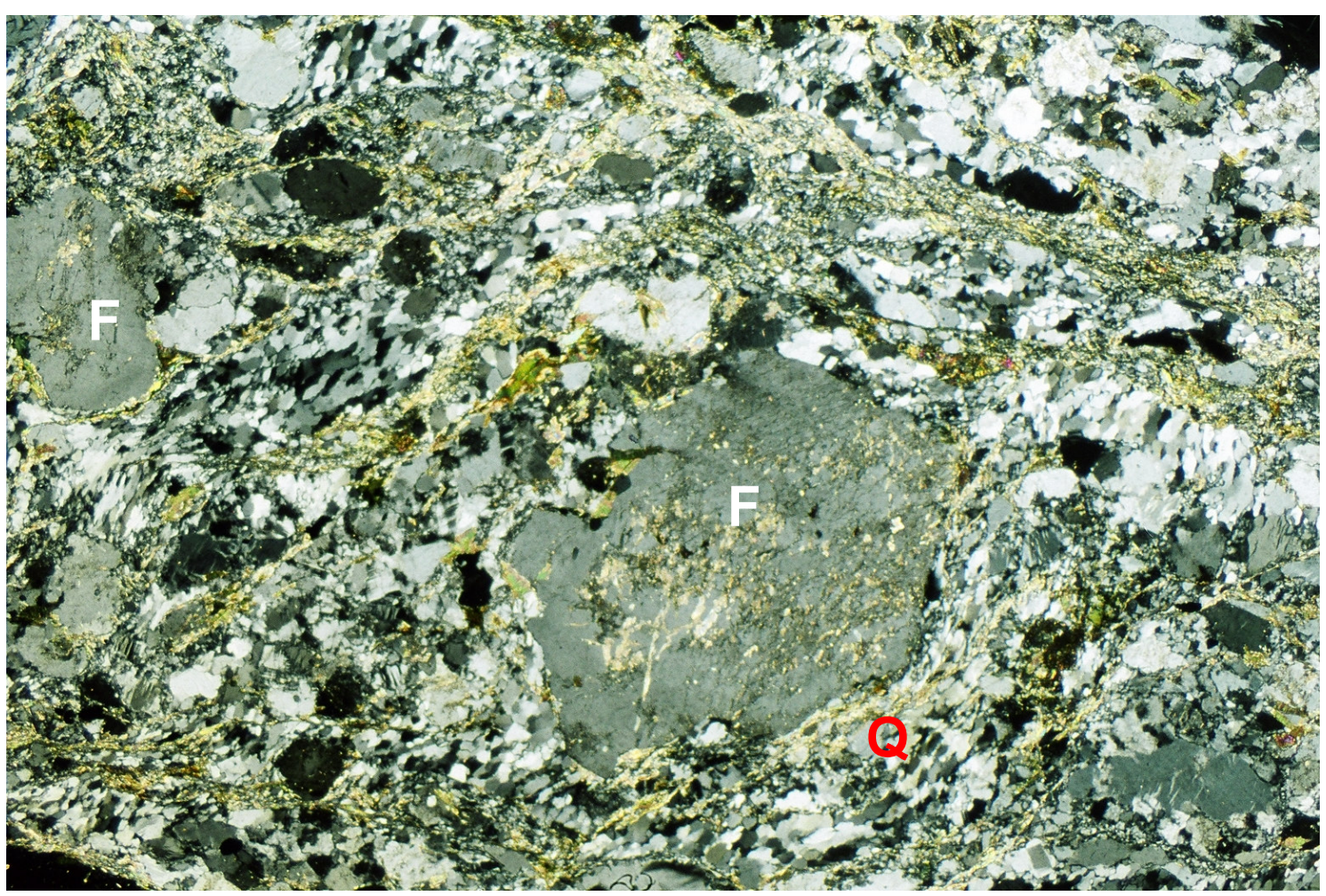

Foto 18 - Aspecto de detalhe da textura da rocha na qual se observam cristais de feldspato (F) triturados envolvidos por matriz de quartzo microgranular $(Q)$ e mica. Microscópio de luz transmitida. Ampliação 25x. 


\section{$>$ Análise petrográfica do basalto}

Os ensaios de caracterização tecnológica da amostra de agregado procedente da Região de Marília/SP revelaram que a rocha é classificada de basalto.

A presença de vidro vulcânico, calcedônia e clorofeíta, substâncias minerais normalmente mal cristalizadas com estruturas cristalinas pouco coesas, desordenadas e com muitos defeitos, são componentes suscetíveis à reação com os álcalis. A Tabela 12 sintetiza as principais características do agregado.

Tabela 12 - Síntese das principais características petrográficas da amostra de basalto

\begin{tabular}{lll}
\hline \multirow{2}{*}{ Mineralogia } & Principal & Plagioclásio andesina An45-50 (28,7\%), augita (38,9\%) \\
\cline { 2 - 3 } & Subordinada & $\begin{array}{l}\text { Opacos }(9,9 \%), \text { vidro escuro rico em ferro (17,9\%), calcedônia } \\
(0,3 \%), \text { clorofeíta }(1,7 \%) \text { e hidróxidos de ferro }(1,9 \%) .\end{array}$ \\
\cline { 2 - 3 } Cor & Deletéria & Vidro escuro rico em ferro, calcedônia, clorofeíta \\
\hline Estrutura & Preta \\
\hline Textura & Maciça \\
\hline Granulação & Glomeroporfirítica e matriz intersetal \\
\hline Estado de alteração & Muito fina \\
\hline Deformação do agregado & Sã a pouco alterada \\
\hline Propriedade físico-mecânica & Não-deformado \\
\hline Forma dos fragmentos & Equidimensional \\
\hline Tipo de rocha & Ígnea \\
\hline Classificação petrográfica & Basalto \\
\hline Reatividade potencial & Potencialmente reativo \\
\hline
\end{tabular}




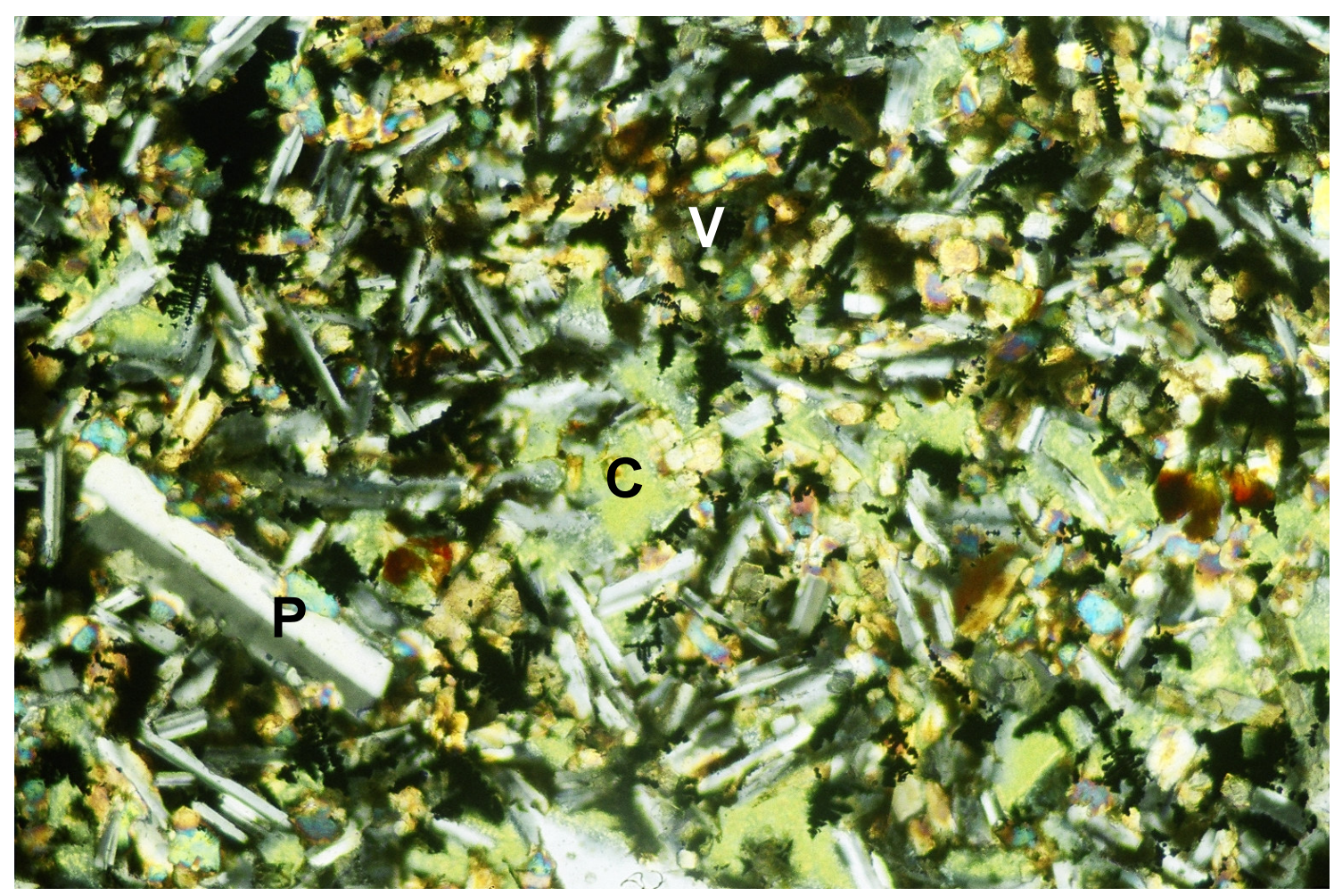

Foto 19 - Aspecto de detalhe da textura da rocha na qual se observam fenocristais de plagioclásio (P) e matriz fina composta de plagioclásio, opacos (magnetita) e clorofeíta (C). $\mathrm{V}=$ masa intersticial composta por opacos e vidro vulcânico. Microscópio de luz transmitida. Ampliação 25x.

\section{> Atividade pozolânica com cal dos agregados}

Determinou-se o índice de atividade pozolânica com cal das amostras de milonito granítico e basalto com objetivo de avaliar se apresentam alguma aptidão à reação com hidróxido de cálcio. As amostras de agregado foram moídas em moinho de bolas em duas granulometria distintas. A Tabela 13 sintetiza os resultados obtidos.

Tabela 13 - Determinação do índice de atividade pozolânica com cal dos agregados

\begin{tabular}{lccc}
\hline Agregados & $\begin{array}{c}\text { Material retido na } \\
\text { peneira de 45 } \mu \mathrm{m}(\%)\end{array}$ & $\begin{array}{c}\text { Área específica } \\
\left(\mathrm{cm}^{2} / \mathrm{g}\right)\end{array}$ & $\begin{array}{c}\text { Índice de atividade } \\
\text { pozolânica com cal }\end{array}$ \\
\hline Milonito granítico & 8,6 & 4970 & $\mathbf{0 , 0}$ \\
\hline Milonito granítico & 0,1 & 10350 & $\mathbf{1 , 2}$ \\
\hline Basalto & 9,5 & 4210 & $\mathbf{2 , 3}$ \\
\hline Basalto & 1,2 & 6720 & $\mathbf{4 , 1}$ \\
\hline
\end{tabular}

Com base nos resultados obtidos observa-se que o basalto apresentou atividade pozolânica com cal e o índice aumenta com a redução da granulometria, enquanto o milonito granítico apresentou um pequeno índice quando finamente dividido. 


\section{$>$ Determinação da reatividade dos agregados (ASTM C 1260)}

Os agregados milonito granítico e basalto foram ensaiados com cimento Portland de alta resistência inicial (sem adição ativa) com objetivo de avaliar o grau de reatividade das amostras. O CP V-ARI utilizado é comprovadamente não mitigador da reação álcali-agregado e apresenta expansão em autoclave inferior a 0,20\%, conforme prescreve o método de ensaio ASTM C 1260.

A expansão média aos 14 dias de cura em solução alcalina é tomada como valor de referência para a estimativa da reatividade potencial do agregado com os álcalis. Valores de expansão superior a $0,20 \%$ aos 14 dias de cura em solução alcalina indicam que o agregado é reativo e que entre $0,10 \%$ e $0,20 \%$, o agregado é potencialmente reativo, necessitando de ensaios complementares para decisão quanto ao uso. Valores de expansão inferiores a 0,10\% indicam que o agregado é inócuo (ASTM C 1260-05a; 2005).

Com base nos resultados obtidos e nos parâmetros mencionados na norma da ASTM C 1260 (Figura 18) podem-se tecer as seguintes considerações:

$>$ O agregado milonito granítico apresentou expansão média das barras de argamassa aos 14 dias de cura em solução alcalina de 0,25\%, indicando que o agregado é reativo segundo os critérios estabelecidos pela ASTM C 1260/05;

O agregado basalto apresentou expansão média das barras de argamassa aos 14 dias de cura em solução alcalina de 0,49\%, indicando que o agregado é reativo segundo os critérios estabelecidos pela ASTM C 1260/05.

Os resultados obtidos pelo método acelerado das barras de argamassa comprovam que os agregados são reativos, conforme indicado pela análise petrográfica. 


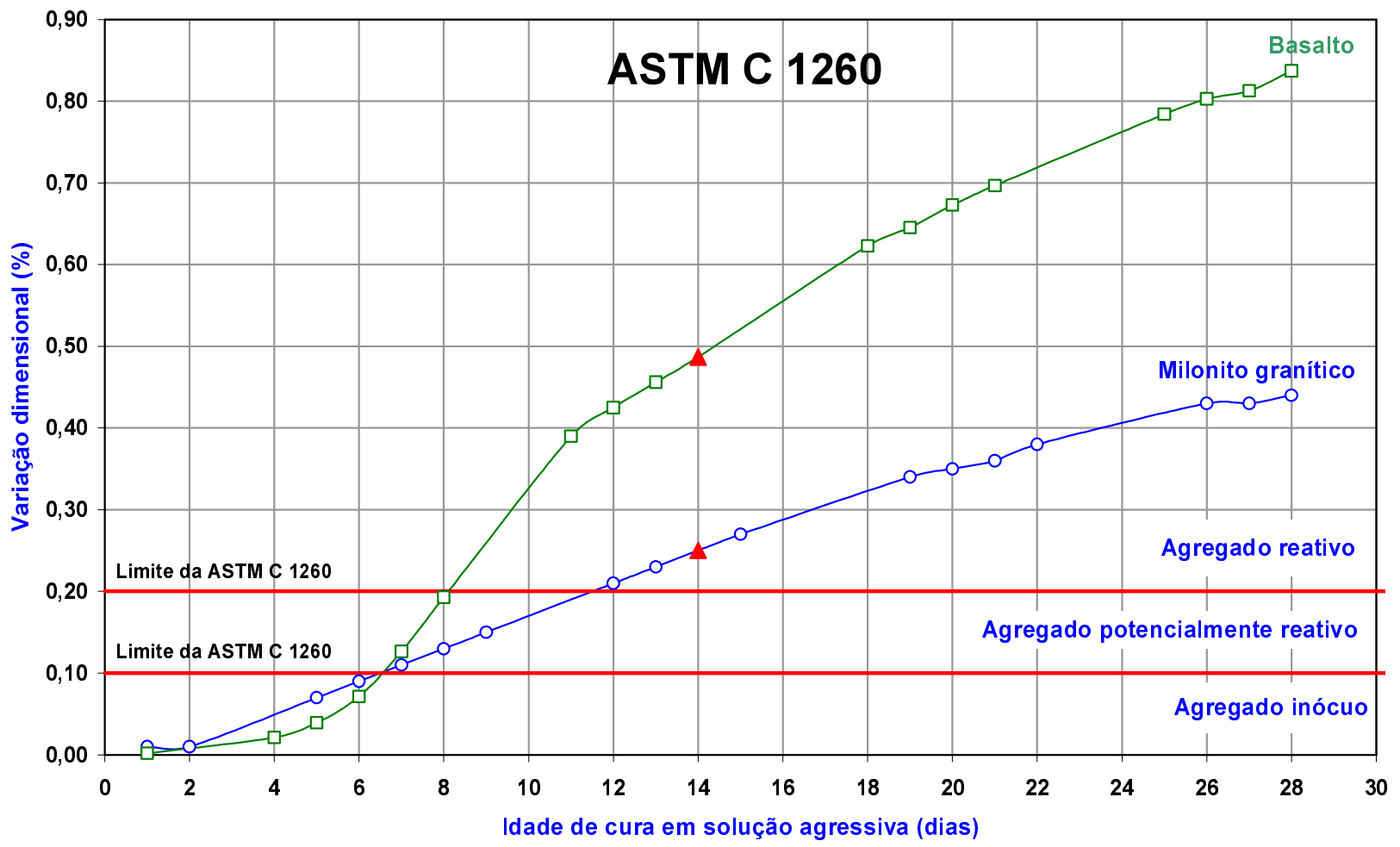

Figura 18 - Evolução da variação dimensional com o tempo de cura em solução alcalina das amostras de agregado 


\section{RESULTADOS DOS ENSAIOS DE REATIVIDADE}

\subsection{Avaliação da Eficiência dos Cimentos com Adições Ativas na Minimização da RAA (ASTM C 1567)}

Com objetivo de mitigar a expansão causada pelas reações álcali-silicato e álcalisílica os agregados reativos milonito granítico e basalto foram combinados com quinze cimentos experimentais preparados a partir da substituição parcial do CP V-ARI por adições ativas, conforme definido no programa experimental. Os ensaios foram realizados pela ASTM C 1567.

Valores de expansão inferiores a $0,10 \%$ aos 14 dias de cura em solução alcalina indicam que a combinação do cimento com adições de escórias de alto-forno, cinza volante, metacaulim ou sílica ativa com 0 agregado analisado apresenta características favoráveis ao emprego em obras de construção civil com baixo risco de desenvolvimento da patologia referente à reação álcali-agregado.

Valores de expansão igual ou superior a $0,10 \%$ indicam que a combinação do cimento com o agregado pode desenvolver expansão deletéria; a norma sugere que a mesma combinação dos materiais deve ser testada no concreto (ASTM C 1293, 2005), ou aumentar os teores das adições e confirmar a minimização através de novos ensaios (ASTM C 1567, 2005).

As Figuras 18 a 25 ilustram a evolução da expansão com a idade de cura em solução alcalina das amostras de milonito granítico e basalto, quando combinadas com os cimentos experimentais com adição de escória de alto-forno, cinza volante, metacaulim e sílica ativa. Os resultados obtidos com CP V-ARI sem adição (referência) são mostrados em todas Figuras. 


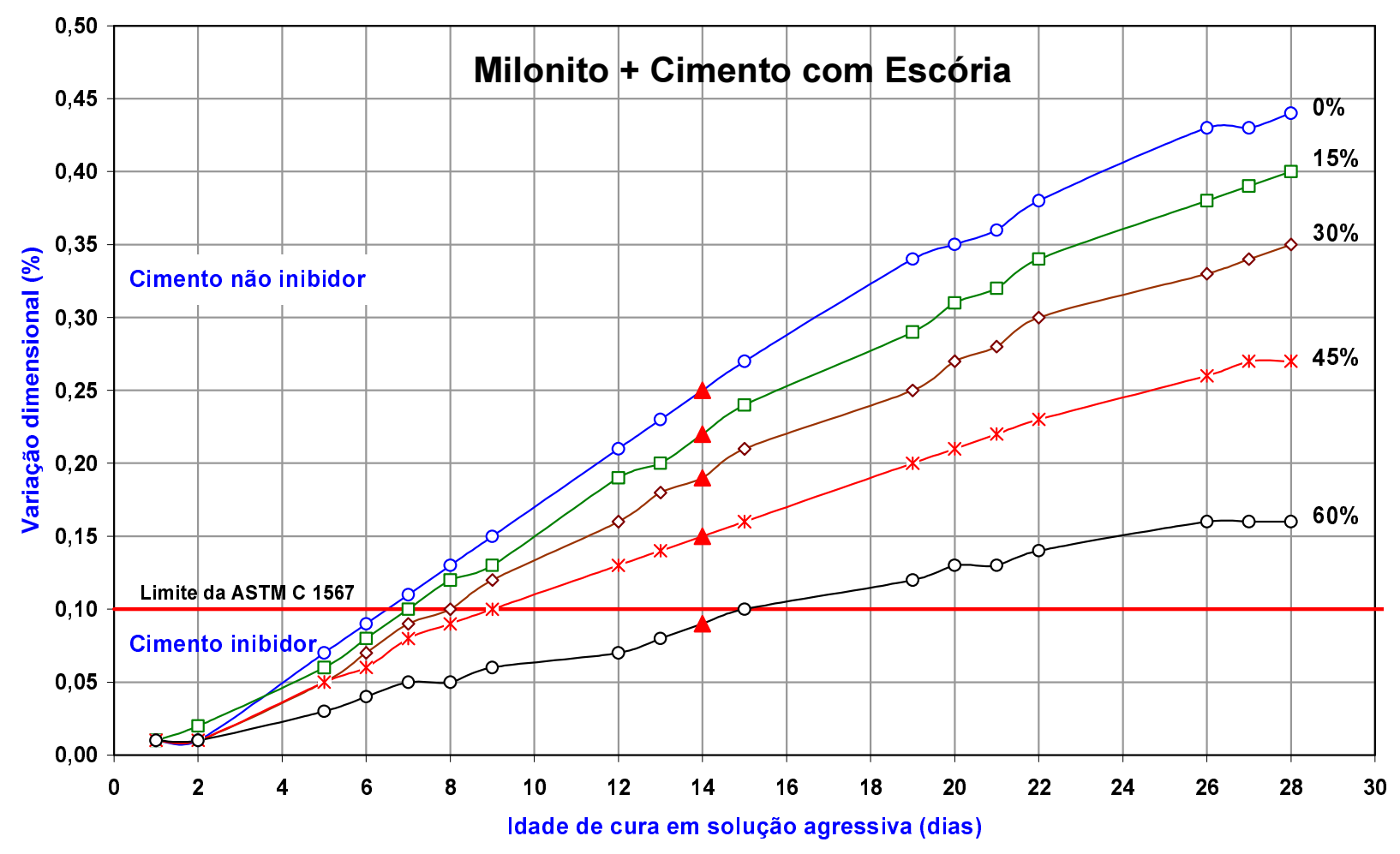

Figura 19 - Variação dimensional - Milonito granítico + Cimento com escória

As barras de argamassa preparadas com cimentos Portland compostos com escória de alto-forno (CP II-E) com teores de 15 e 30\% apresentaram expansão aos 14 dias de cura em solução alcalina de $0,22 \%$ e 0,19\%, respectivamente, indicando que o teor adicionado não foi suficiente para mitigar a reação álcalisilicato da amostra de milonito granítico.

As barras de argamassa preparadas com os cimentos Portland de alto-forno (CP III) com teores de 45\% e 60\% apresentaram expansão aos 14 dias de cura em solução alcalina de 0,15\% e 0,09\%, respectivamente. Os resultados indicam que a reação álcali-silicato foi mitigada para valores aceitáveis pela ASTM C 1567 com um mínimo de $60 \%$ de escória. 


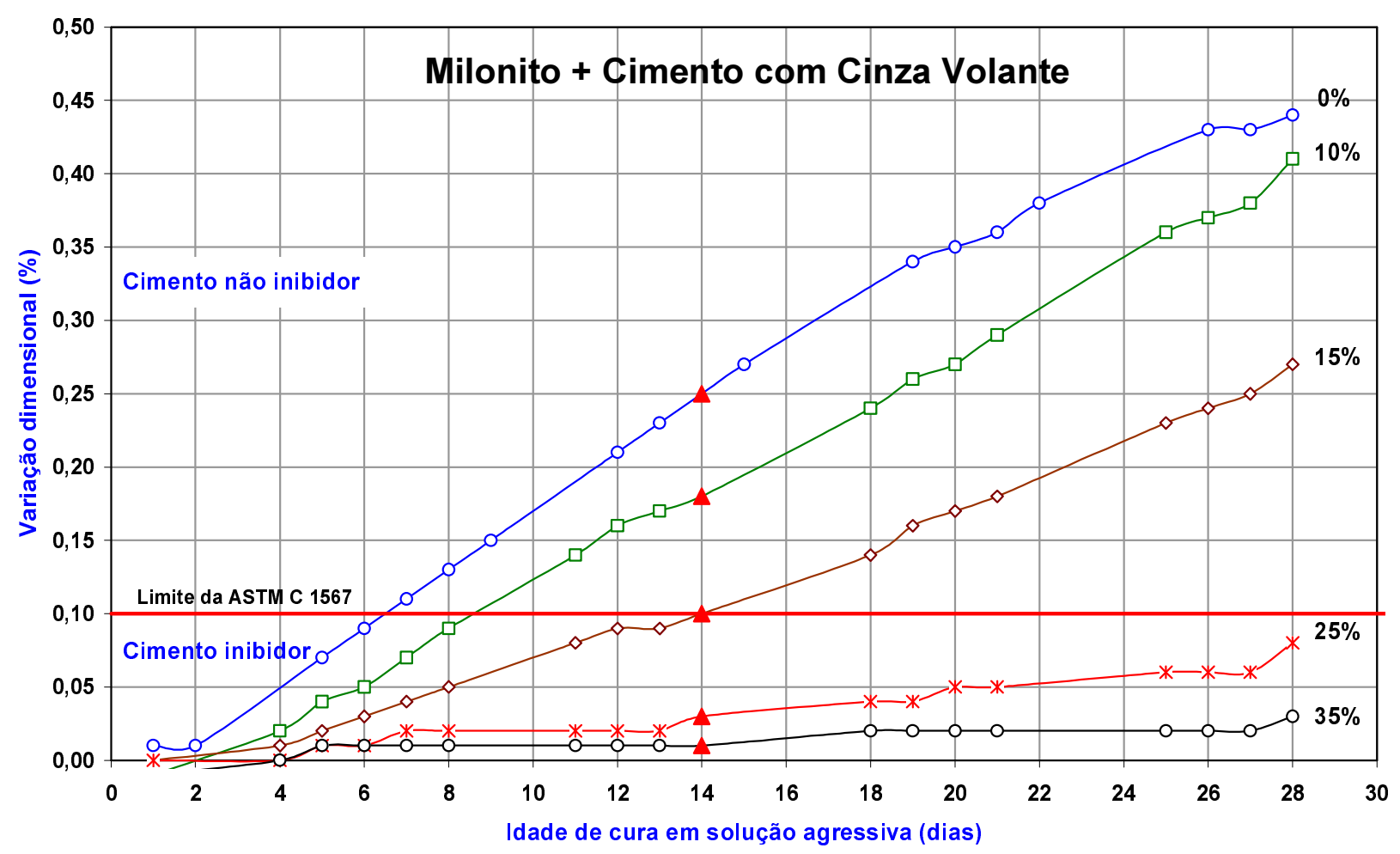

Figura 20 - Variação dimensional - Milonito granítico + Cimento com cinza volante

As barras de argamassa preparadas com os cimentos Portland compostos com cinza volante (CP II-Z) com adição de 10\% e 15\% de adição apresentaram expansão aos 14 dias de cura em solução alcalina de 0,18\% e 0,10\%, respectivamente, concluindo-se que a reação álcali-silicato pode ser mitigada quando o teor de cinza volante adicionado ao cimento for superior a $15 \%$.

As barras de argamassa preparadas com os cimentos Portland pozolânicos com cinza volante (CP IV) com adição de $25 \%$ e $35 \%$ de adição apresentaram expansão aos 14 dias de cura em solução alcalina de 0,03\% e 0,01\%, respectivamente, mitigando a reação álcali-silicato. 


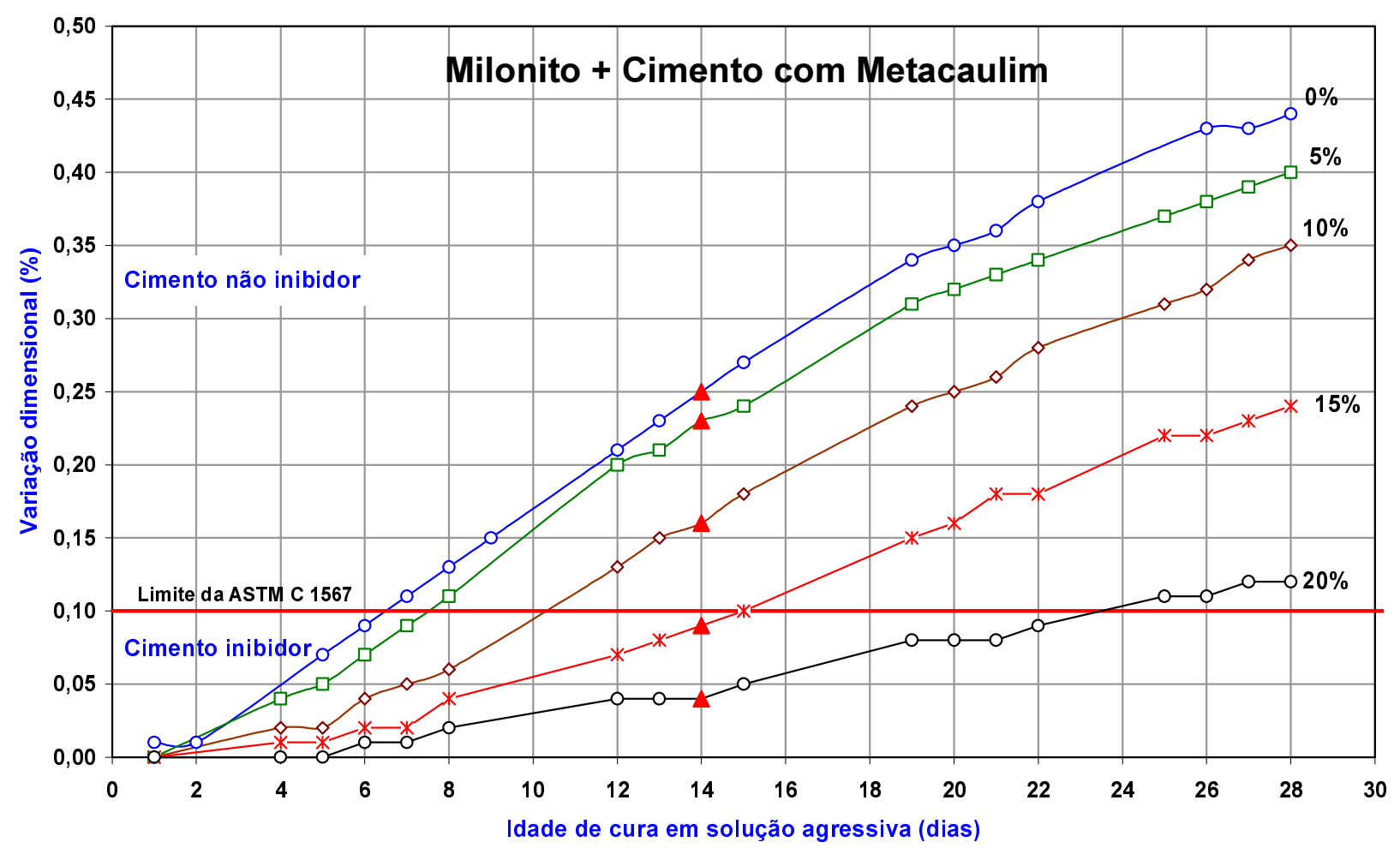

Figura 21 - Variação dimensional - Milonito granítico + Cimento com metacaulim

As barras de argamassa preparadas com os cimentos com adição de metacaulim nos teores de 5 e 10, 15 e 20\% apresentaram expansão aos 14 dias de cura em solução alcalina de 0,23 e 0,16, 0,09 e 0,04\%, respectivamente, indicando que valores de expansão inferiores a $0,10 \%$ aos 14 dias de cura em solução alcalina foram atingidos com teores de adição igual ou superiores a $15 \%$. 


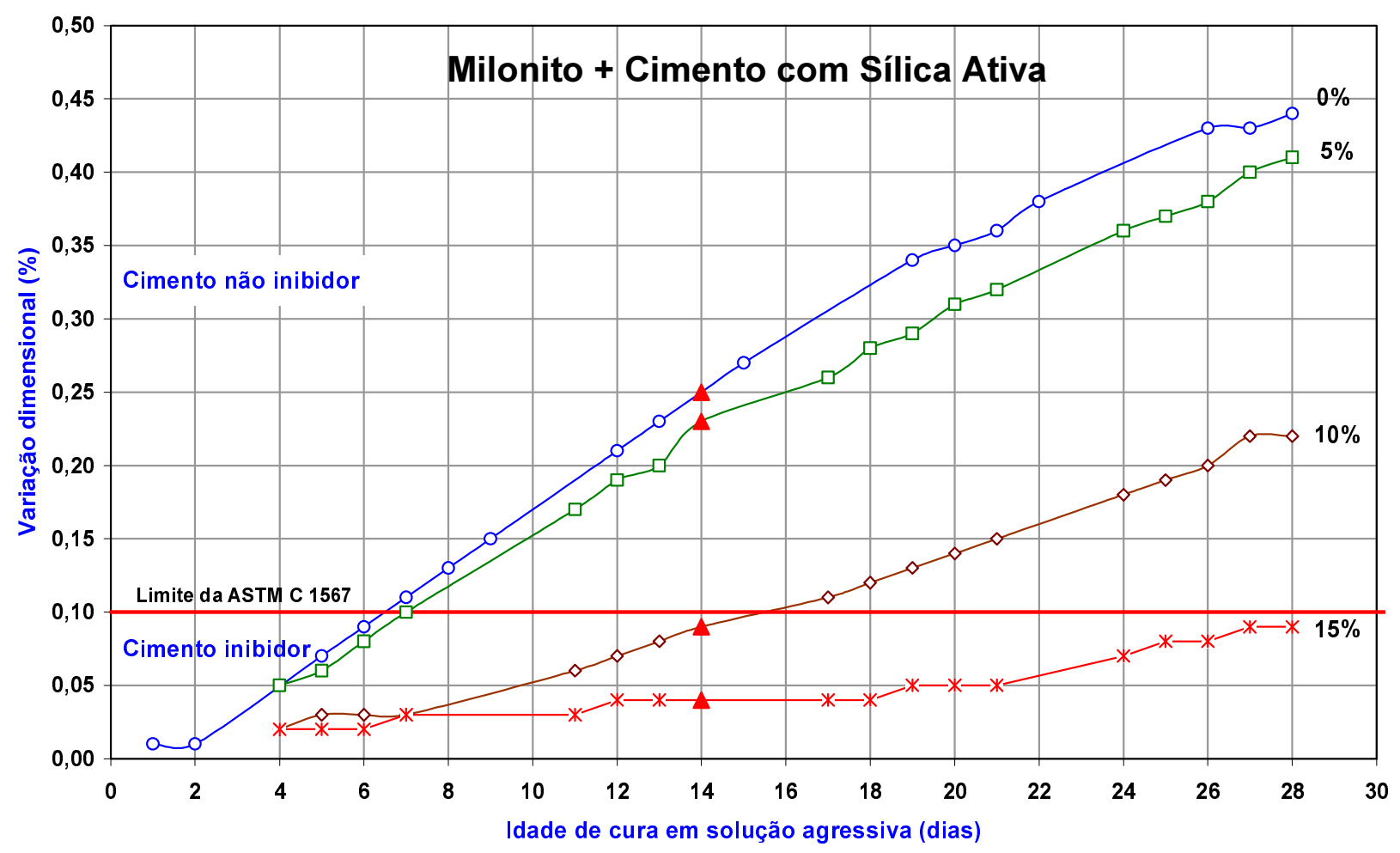

Figura 22 - Variação dimensional - Milonito granítico + Cimento com sílica ativa

As barras de argamassa preparadas com os cimentos com adição de sílica ativa nos teores de 5, 10 e 15\% apresentaram valores médios de expansão aos 14 dias de cura em solução alcalina de 0,23 e 0,09 e 0,04\%, respectivamente, indicando que teores superiores a 10\% são suficientes para mitigar a reação.

Observa-se no gráfico que a expansão média das barras com 5\% de sílica ativa ficou próxima dos valores do cimento sem adição; entretanto não se observou o teor péssimo normalmente citado na literatura, no qual há um aumento da expansão. A adição de $10 \%$ de sílica ativa reduziu de forma acentuada a expansão em relação ao teor de $5 \%$.

O teor de $15 \%$ foi bastante efetivo na minimização da expansão mantendo-se abaixo, mesmo na idade de 28 dias. 


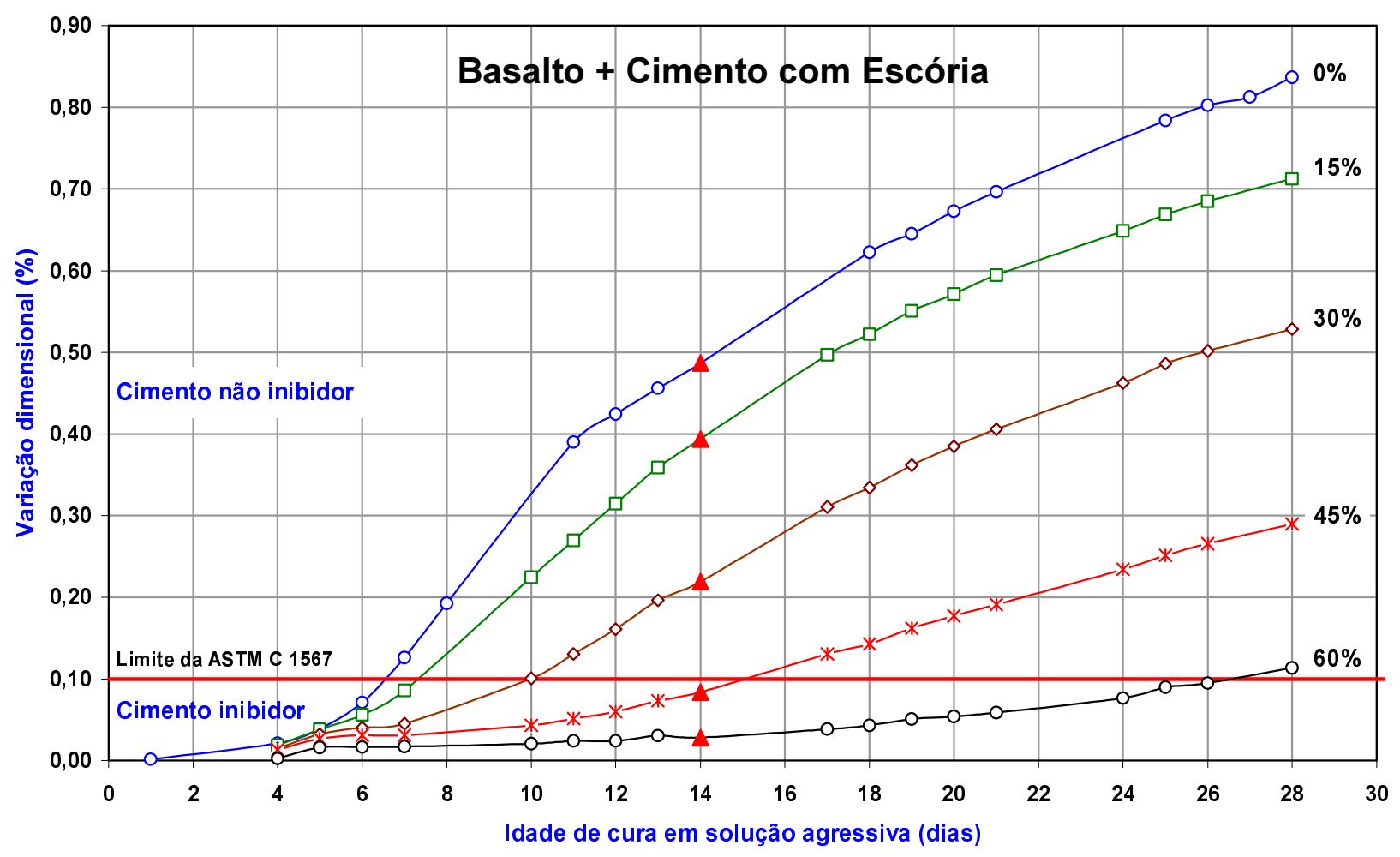

Figura 23 - Variação dimensional - Basalto + Cimento com escória

As barras de argamassa preparadas com cimentos Portland compostos com escória de alto-forno (CP II-E) com teores de 15 e 30\% apresentaram expansão aos 14 dias de cura em solução alcalina de 0,39\% e 0,22\%, respectivamente, indicando que os teores adicionados não foram suficientes para mitigar a reação álcali-sílica da amostra de basalto.

As barras de argamassa preparadas com os cimentos Portland de alto-forno (CP III) com teores de 45\% e 60\% apresentaram expansão aos 14 dias de cura em solução alcalina de $0,08 \%$ e $0,03 \%$, respectivamente. Os resultados indicam que a reação álcali-sílica do basalto pode ser mitigada para valores aceitáveis pela ASTM C 1567 com um mínimo de 45\% de escória. 


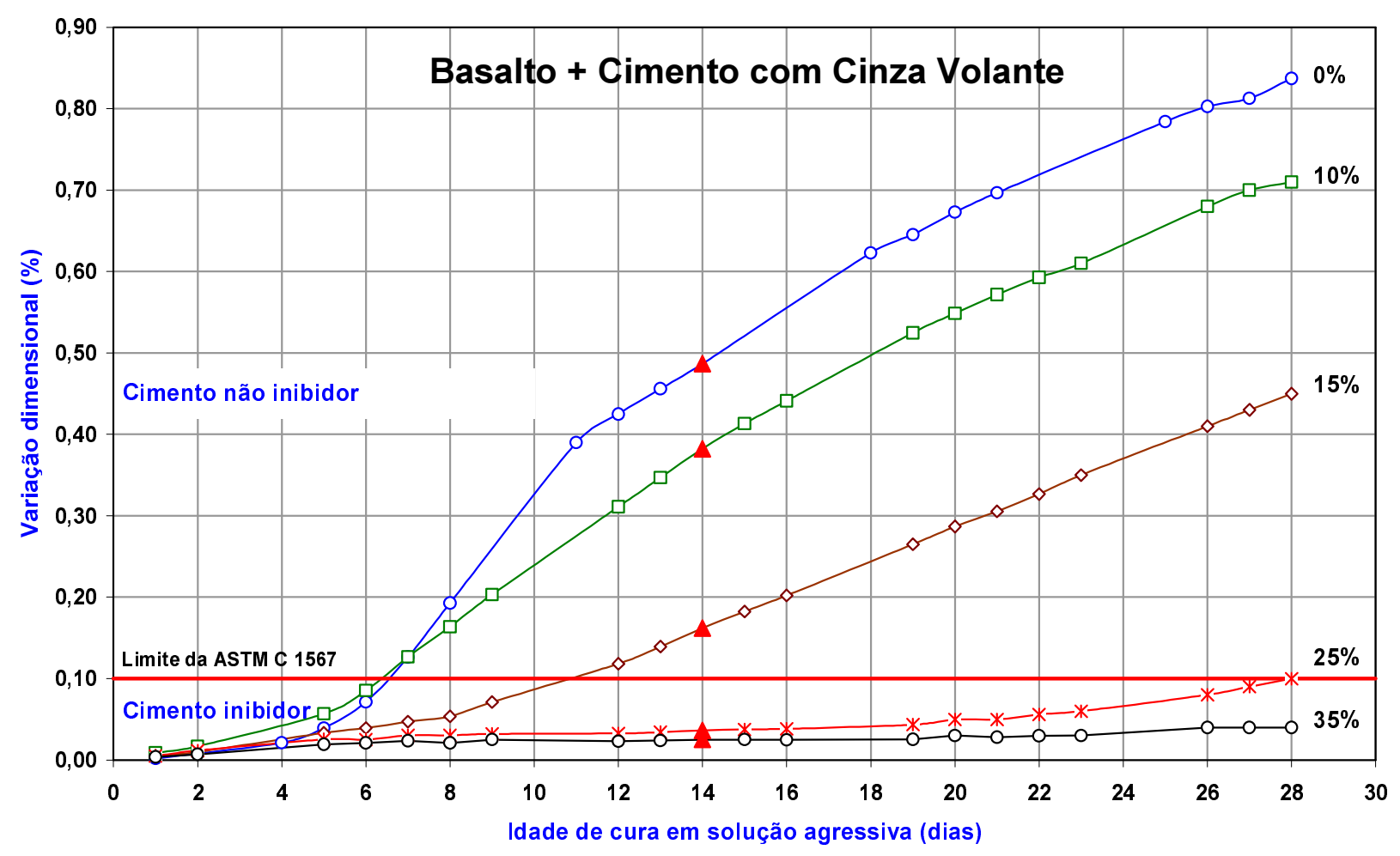

Figura 24 - Variação dimensional - Basalto + Cimento com cinza volante

As barras de argamassa preparadas com os cimentos Portland compostos com cinza volante (CP II-Z), com adição de 10 e 15\% apresentaram expansão aos 14 dias de cura em solução alcalina de 0,38\% e 0,16\%, respectivamente, indicando que os teores adicionados não foram suficientes para mitigar a reação álcali-sílica da amostra de basalto.

As barras de argamassa preparadas com os cimentos Portland pozolânicos com cinza volante (CP IV) com adição de 25 e $35 \%$ de adição apresentaram expansão aos 14 dias de cura em solução alcalina de 0,04\% e 0,03\%, respectivamente, indicando que esses teores são adequados para mitigar a reação álcali-sílica do basalto. 


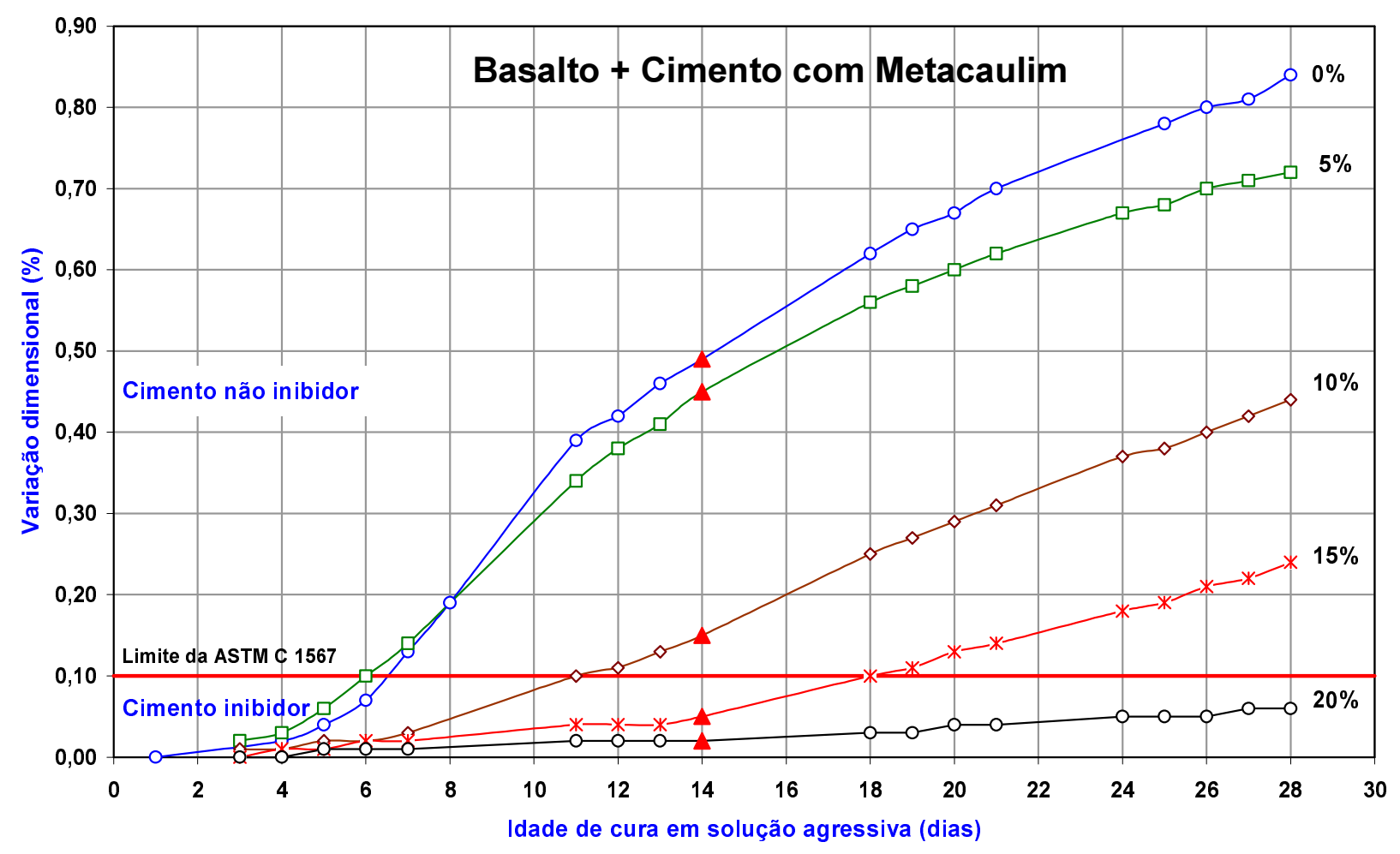

Figura 25 - Variação dimensional - Basalto + Cimento com metacaulim

As barras de argamassa preparadas com os cimentos com adição de metacaulim nos teores de 5 e 10, 15 e 20\% apresentaram expansão aos 14 dias de cura em solução alcalina de 0,45 e 0,15, 0,05 e 0,01\%, respectivamente, indicando que teores acima de $15 \%$ são adequados para mitigar a reação álcali-sílica do basalto. 


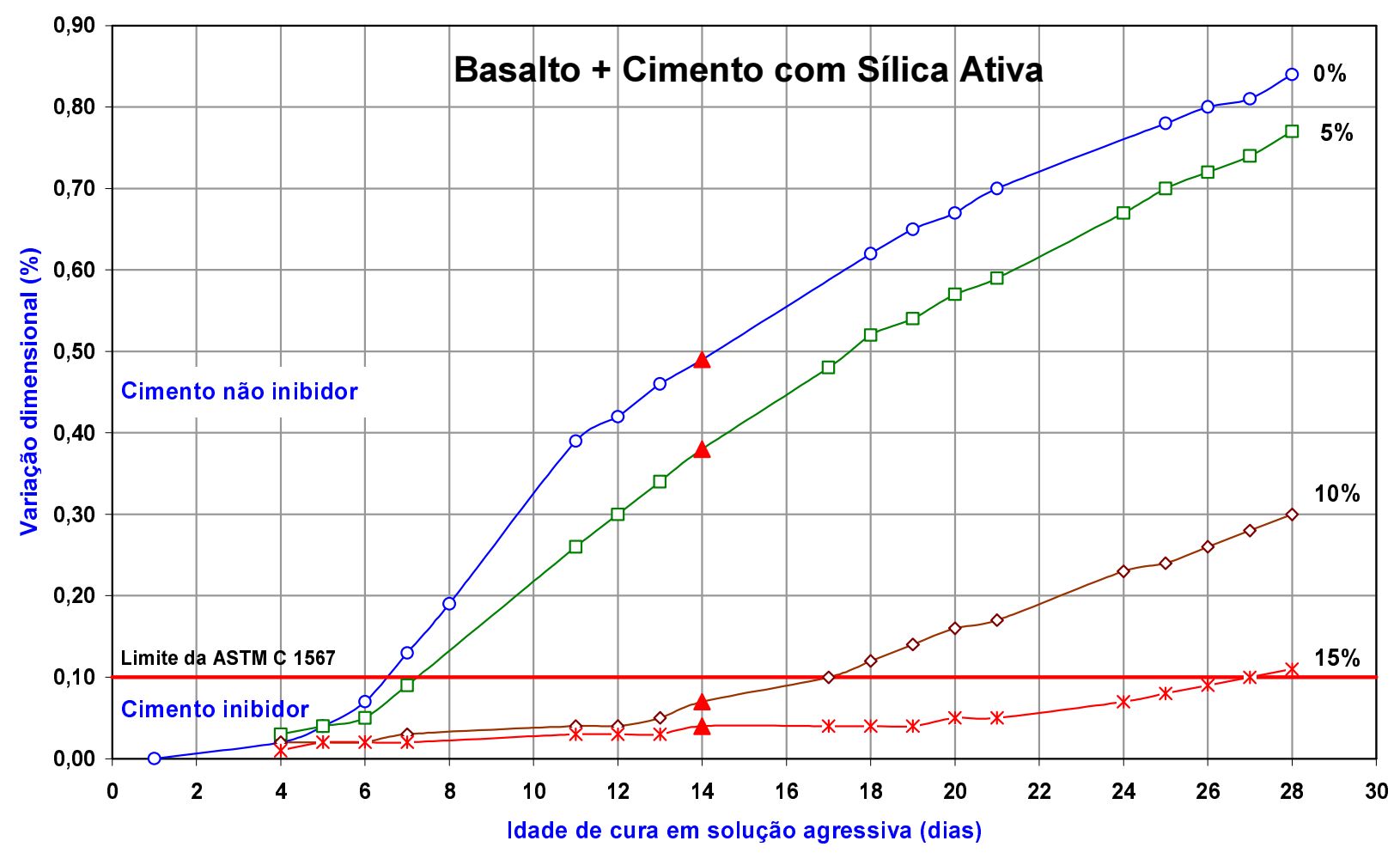

Figura 26 - Variação dimensional - Basalto + Cimento com sílica ativa

As barras de argamassa preparadas com os cimentos com adição de sílica ativa nos teores de 5, 10 e 15\% apresentaram valores médios de expansão aos 14 dias de cura em solução alcalina de 0,38 e 0,07 e 0,04\%, respectivamente, indicando que teores superiores a 10\% são suficientes para mitigar a reação.

A adição de $10 \%$ de sílica ativa reduziu de forma acentuada a expansão em relação ao teor de $5 \%$. 


\subsection{Efeito das Adições Ativas nas Propriedades Mecânicas}

Determinaram-se as resistências à tração na flexão (Figura 27) e à compressão (Figura 28) das barras de argamassa moldadas com os agregados milonito granítico e basalto, com os cimentos com e sem adições ativas, e submetidas ao ensaio acelerado a $80^{\circ} \mathrm{C}$ em solução $1 \mathrm{~N}$ durante 28 dias.

Os resultados obtidos indicam que há uma tendência das resistências à compressão das barras de argamassa moldadas com agregado basalto serem maiores que as obtidas com agregado milonito granítico. Essa constatação está relacionada provavelmente à textura da rocha, melhor aderência pasta-agregado, à homogeneidade mineralógica do basalto, maior resistência à compressão da rocha. Não foi possível estabelecer correlação entre a atividade pozolânica do basalto, obtida com o material moído, e o desempenho mecânico apresentado.

Observa-se também que a resistência à compressão é maior quando da utilização do cimento com adição de escória de alto-forno, que provavelmente está relacionada à ativação térmica e química da escória em função da temperatura do ensaio $\left(80^{\circ} \mathrm{C}\right)$ e da alcalinidade da solução na qual as barras foram ensaiadas. 


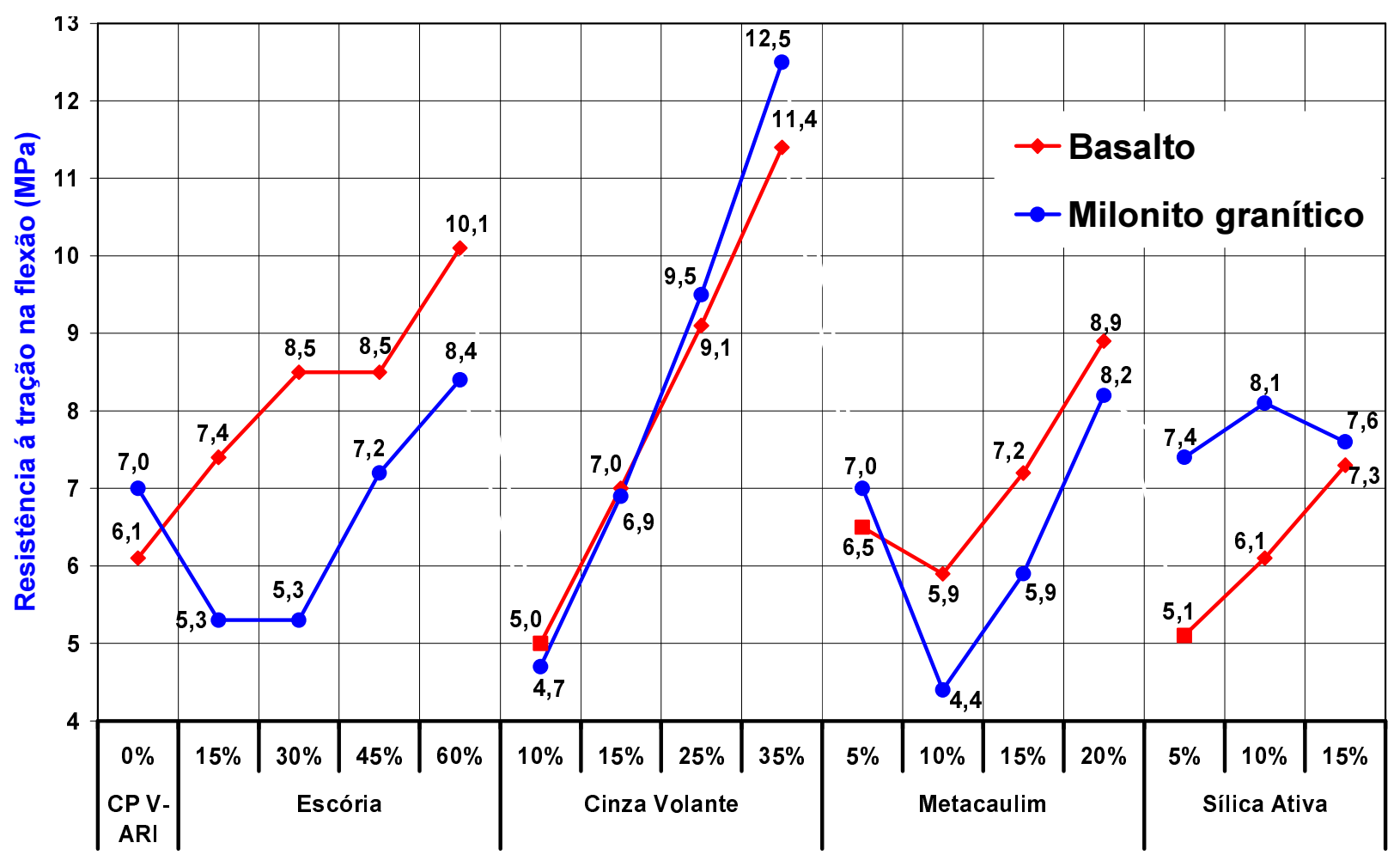

Figura 27 - Resistência à tração na flexão das barras de argamassa submetidas aos ensaios acelerados a $80^{\circ} \mathrm{C}$, em solução $1 \mathrm{~N}$ de $\mathrm{NaOH}$ durante 28 dias.

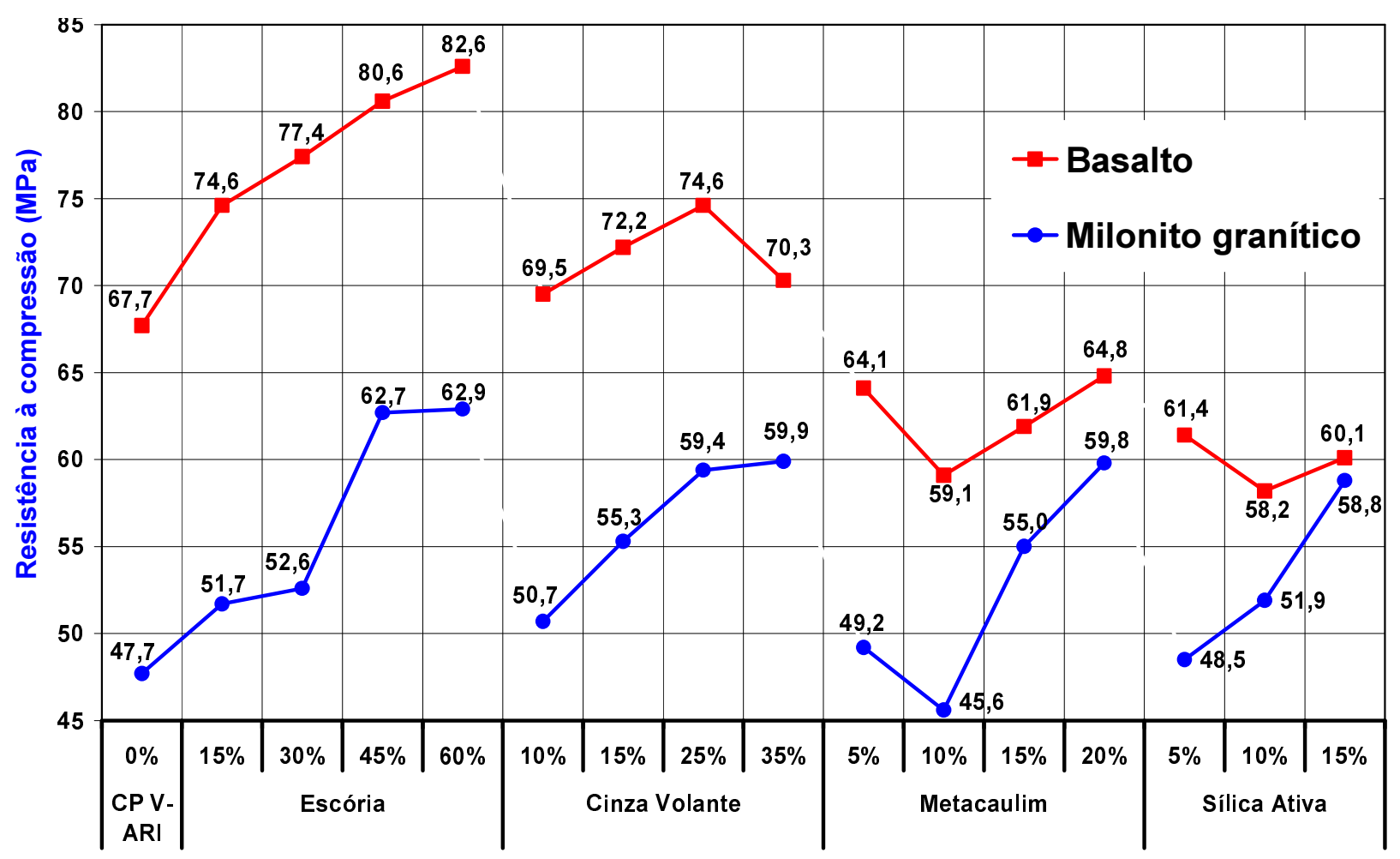

Figura 28 - Resistência à compressão das barras de argamassa submetidas aos ensaios acelerados a $80^{\circ} \mathrm{C}$, em solução $1 \mathrm{~N}$ de $\mathrm{NaOH}$ durante 28 dias 


\subsection{Análise Térmica e Termogravimétrica das Barras de Argamassa}

A Figura 29 apresenta os teores de hidróxido de cálcio $\left(\mathrm{Ca}(\mathrm{OH})_{2}\right)$, calculados na base seca, das barras de argamassa moldadas com o agregado milonito granítico.

Observa-se que à medida que aumenta o teor de adição ativa nos cimentos há uma redução gradual do teor de hidróxido de cálcio, indicando uma combinação com os componentes das adições ativas (cinza volante, metacaulim e sílica ativa), através das reações pozolânicas, com formação adicional de produtos hidratados C-S-H. No caso da escória de alto-forno a redução do teor de $\left(\mathrm{Ca}(\mathrm{OH})_{2}\right)$ deve-se principalmente à diluição do clínquer do cimento.

Comparando-se os teores de hidróxido de cálcio das barras de argamassa moldadas com os cimentos com $15 \%$ de adição, observa-se que a sílica ativa e o metacaulim apresentam os menores teores, confirmando a alta reatividade desses materiais pozolânicos em reagir com $\mathrm{Ca}(\mathrm{OH})_{2}$ para formar produtos hidratados.

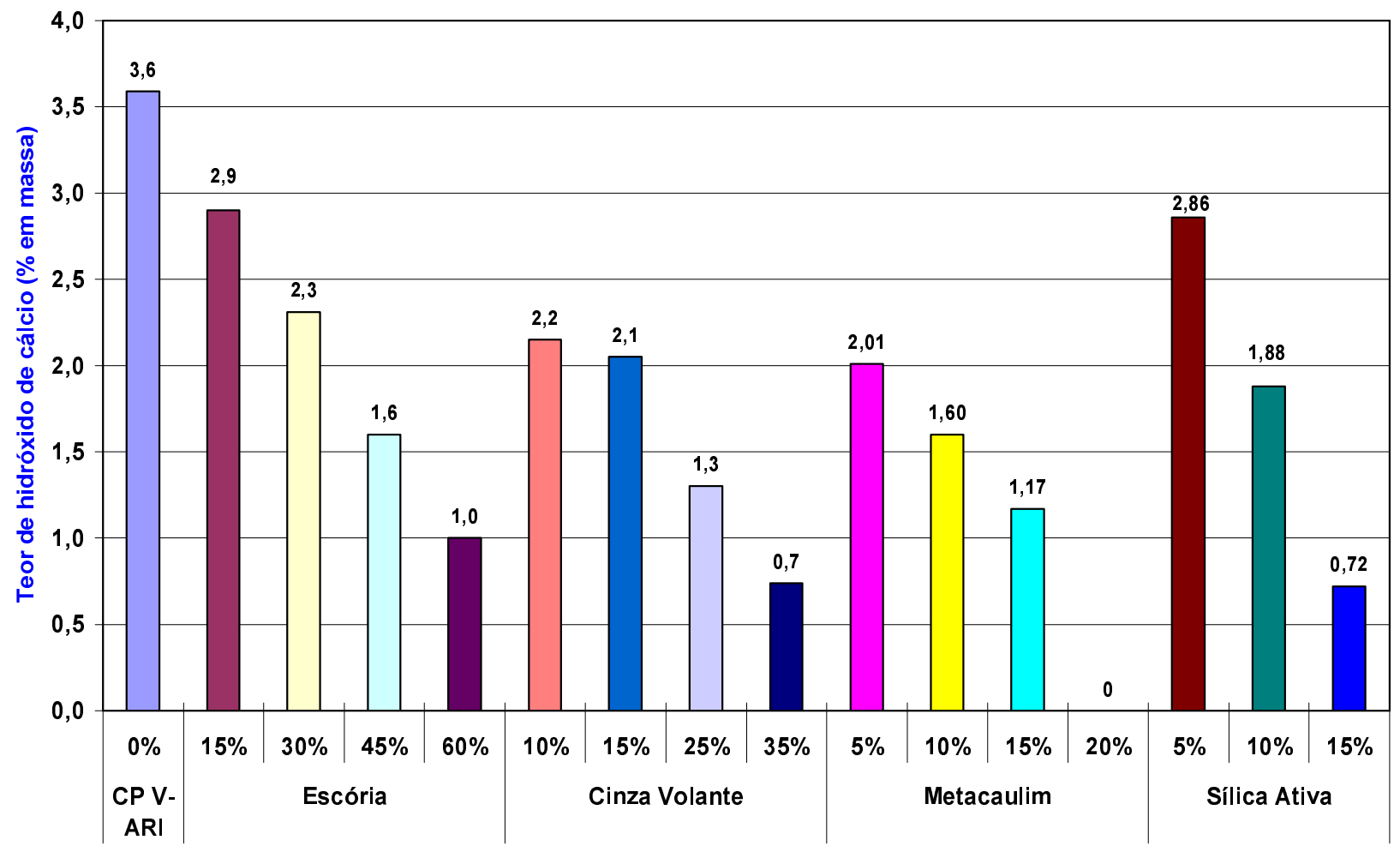

Figura 29 -Teor de hidróxido de cálcio das barras de argamassa com agregado milonito granítico 


\subsection{Teor de Álcalis das Barras de Argamassa}

Determinaram-se os teores de $\mathrm{K}_{2} \mathrm{O}$ e $\mathrm{Na}_{2} \mathrm{O}$ solúveis das barras de argamassa moldadas com o agregado milonito granítico, com os cimentos com e sem adições ativas, e submetidas ao ensaio acelerado a $80^{\circ} \mathrm{C}$, em solução $1 \mathrm{~N}$ de $\mathrm{NaOH}$ durante 28 dias. A Figura 30 ilustra os resultados obtidos.

$\mathrm{O} \mathrm{Na}_{2} \mathrm{O}$ solúvel das barras é proveniente essencialmente da solução alcalina $1 \mathrm{~N}$, sendo a contribuição dos cimentos pouco significativa $(<0,03 \%)$. Os resultados indicam migração de $\mathrm{Na}_{2} \mathrm{O}$ da solução alcalina para a barra, conferindo disponibilidade inesgotável de álcalis e, conseqüentemente, de íons hidroxila necessários à reação.

$\mathrm{O}$ teor de $\mathrm{Na}_{2} \mathrm{O}$ diminui gradativamente à medida que $\mathrm{o}$ teor de adição ativa aumenta nos cimentos, provavelmente relacionado à menor permeabilidade conferida à argamassa pelas adições ativas. Embora haja tendência à diminuição, observa-se que os teores são próximos tendendo a um equilíbrio.

$\mathrm{O}$ teor de $\mathrm{K}_{2} \mathrm{O}$ solúvel nas barras moldadas com os cimentos com escória de altoforno, cinza volante e metacaulim é inferior a $0,10 \%$, indicando que a maior parte proveniente dos cimentos reagiu e estão presentes nos produtos da reação álcaliagregado ou incorporado ao C-S-H.

Nos cimentos com adição de sílica ativa os teores determinados nas barras moldadas com os cimentos com 10 e $15 \%$ de sílica ativa foram de $0,15 \%$ e $0,18 \%$, respectivamente, indicando que houve contribuição da sílica ativa, que apresentou $2,40 \%$ de $\mathrm{K}_{2} \mathrm{O}$ total na análise química. 


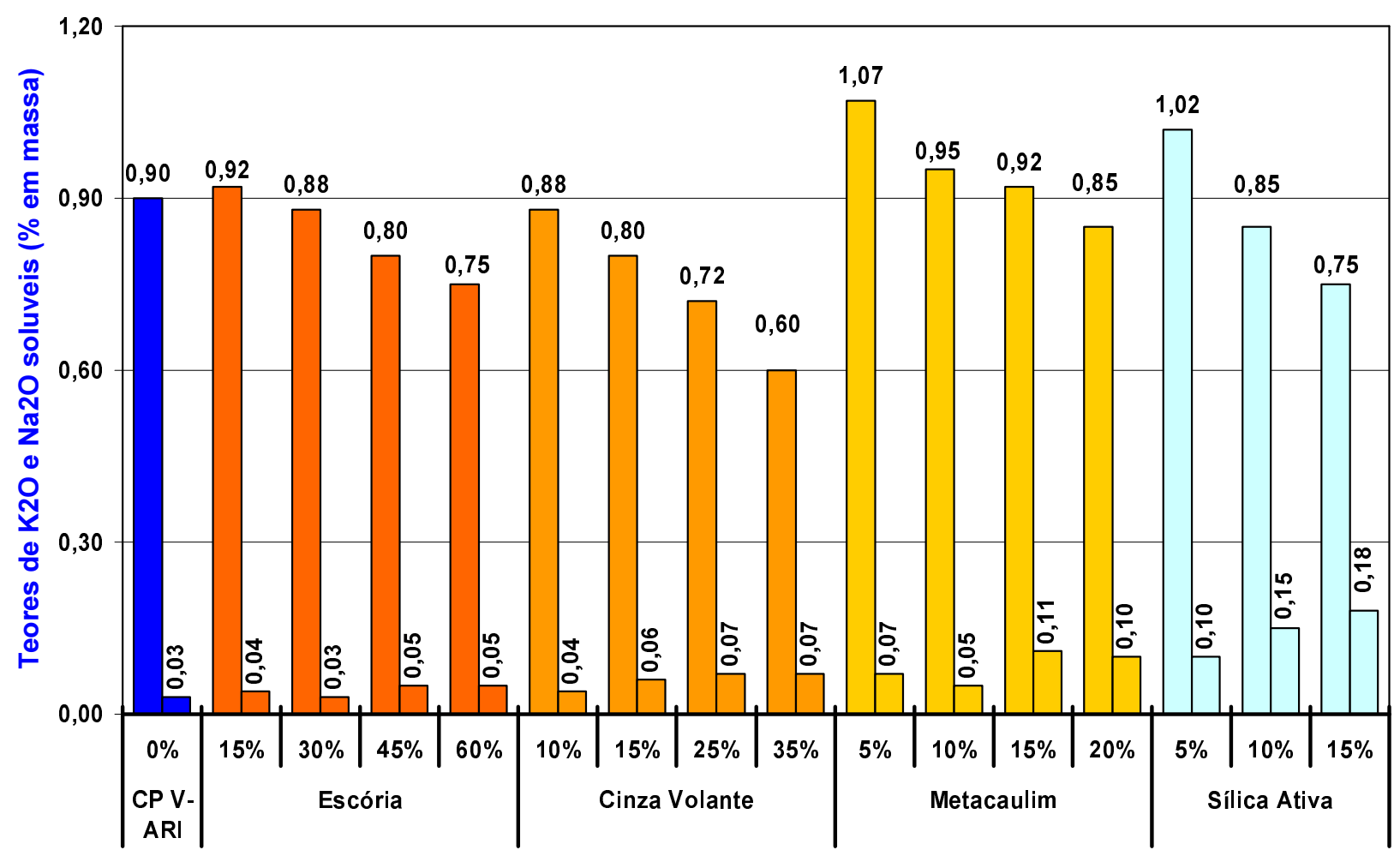

Figura 30 - Teores de $\mathrm{K}_{2} \mathrm{O}$ (entre 0,03\% e 0,18\%) e de $\mathrm{Na}_{2} \mathrm{O}$ (entre 0,60\% e 1,07\%) solúveis das barras de argamassa com agregado milonito granítico

\subsection{Porosimetria por Intrusão de Mercúrio das Barras de Argamassa}

Os ensaios foram realizados nas barras de argamassa moldadas com os agregados milonito granítico e basalto, com os cimentos sem adição ativa e com $60 \%$ de escória, $35 \%$ de cinza volante, $20 \%$ de metacaulim e $15 \%$ de sílica ativa, e submetidas ao ensaio acelerado a $80^{\circ} \mathrm{C}$, em solução $1 \mathrm{~N}$ de $\mathrm{NaOH}$ durante 28 dias.

Há um conceito bem estabelecido e comprovado pela literatura de que as adições ativas contribuem para o refinamento do tamanho dos poros na estrutura de pastas hidratadas, mas tendem a aumentar a porosidade total. Por outro lado, o produto da RAA gerado no ensaio acelerado contribui para a redução da porosidade total da argamassa. Os resultados mostrados a seguir levam em consideração além desses parâmetros, o fato de que as amostras foram submetidas à cura térmica e a formação de gel alcalino em escala dependente do tipo e teor de adição utilizada e do grau de reatividade do agregado. 
A Figura 31 apresenta graficamente o volume de intrusão de mercúrio por grama de amostra $(\mathrm{ml} / \mathrm{g})$ em função do diâmetro dos poros e também a porosidade total de cada amostra ensaiada. O volume de mercúrio intrudido representa a quantidade de poros de um determinado diâmetro.

Com base nos resultados obtidos podem-se tecer as seguintes considerações:

As argamassas moldadas com os cimentos com as adições ativas apresentaram maior volume de poros na faixa inferior a $0,05 \mu \mathrm{m}$, citada na literatura como a mais adequada para reduzir a permeabilidade e aumentar as resistências, confirmando a contribuição das adições ativas no refinamento do tamanho dos poros.

- As argamassas moldadas com cimento sem adição apresentaram a mesma tendência, indicando que também houve refinamento dos poros, mas não relacionado com as adições ativas, mas, sim, com o produto da reação álcaliagregado, que também contribuiu para o preenchimento dos poros. A porosidade determinada com agregado milonito granítico foi de 13,1\%, valor inferior ao obtido com o agregado basalto (14,3\%). Esses resultados estão coerentes com as análises microscópicas, que indicaram maior incidência de gel alcalino nos poros da barra referente ao agregado milonito granítico em relação às barras moldadas com basalto.

As argamassas moldadas com os cimentos com 35\% de cinza volante, $20 \%$ de metacaulim e $15 \%$ de sílica ativa com ambos os agregados, apresentaram porosidades variando de $16,2 \%$ a $18,0 \%$, relativamente maiores que as moldadas com cimento sem adição, provavelmente devido à minimização da reação álcaliagregado, com menor formação de gel.

As argamassas moldadas com o cimento com $60 \%$ de escória de alto-forno apresentaram as menores porosidades dentre as amostras analisadas, indicando que a ativação térmica e química da escória contribui para a formação de maior quantidade de produtos hidratados que preencheram os poros, resultados coerentes com os de resistência à compressão, que também foram os maiores dentre as amostras analisadas. 
Milonito granítico
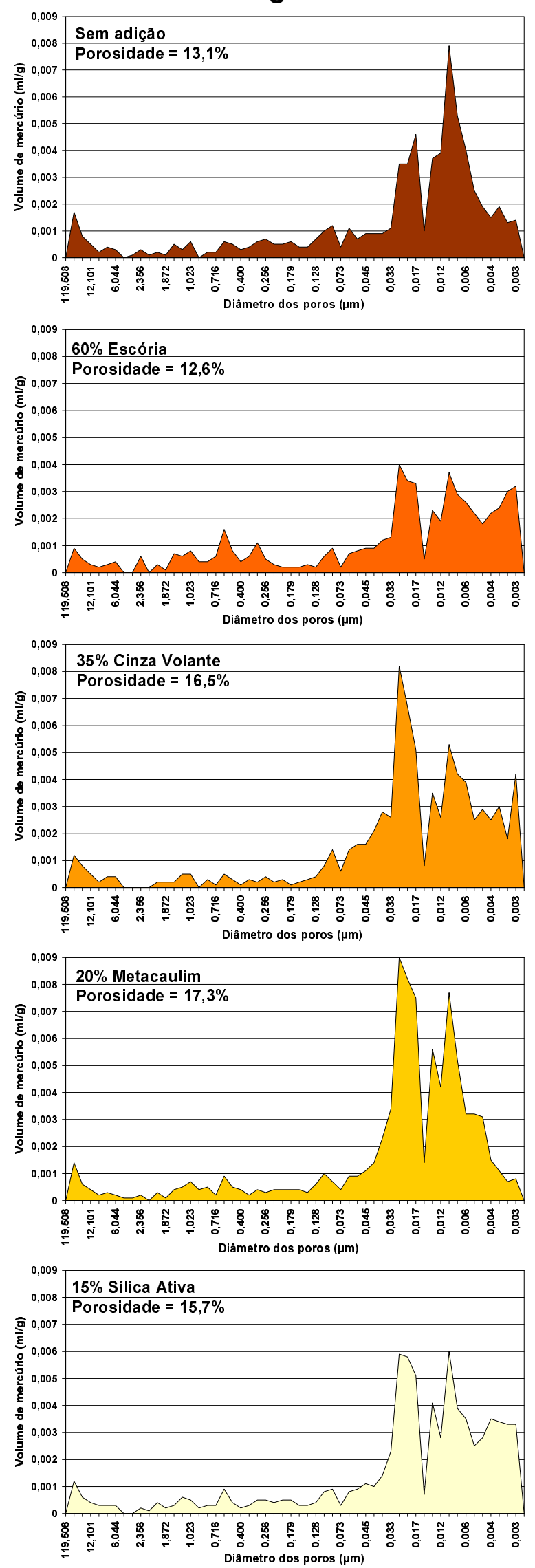

Basalto
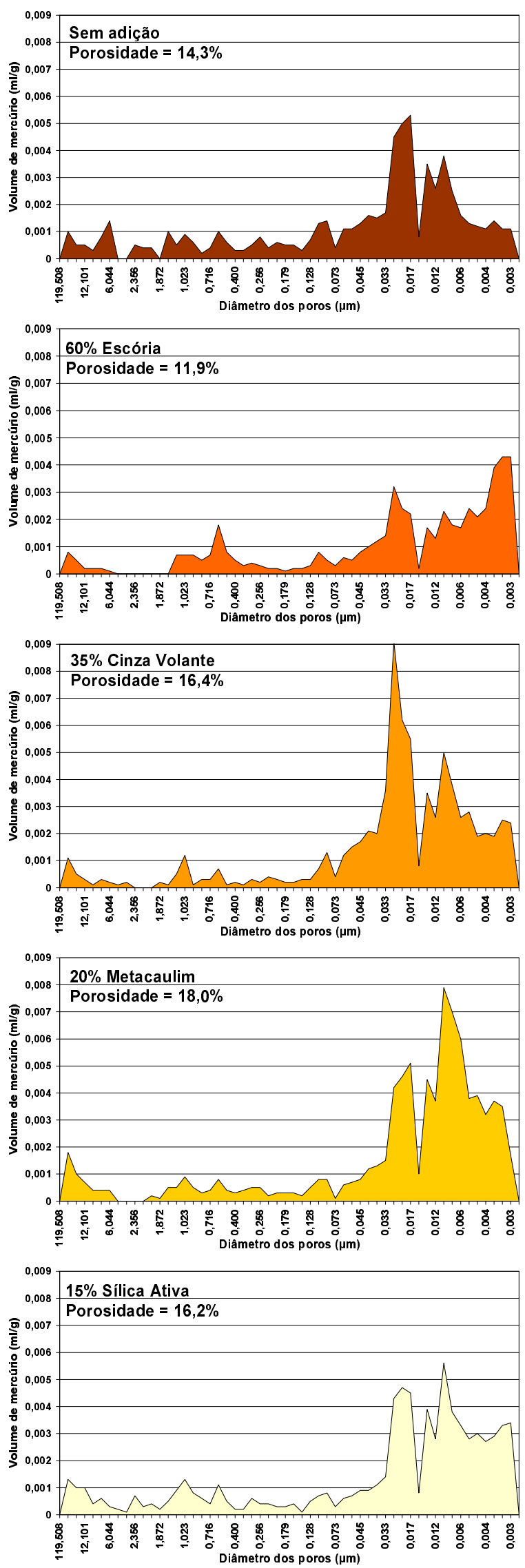

Figura 31 - Volume de intrusão de mercúrio por grama de amostra $(\mathrm{ml} / \mathrm{g})$ em função da quantidade de poros de um determinado diâmetro 


\subsection{Análise Microscópica das Barras de Argamassa}

Após a realização dos ensaios acelerados em solução alcalina $1 \mathrm{~N}$ de $\mathrm{NaOH}$ a $80^{\circ} \mathrm{C}$ durante 28 dias, as barras de argamassa foram analisadas ao microscópio estereoscópico, ao microscópio óptico de luz transmitida e ao microscópio eletrônico de varredura (MEV) com espectrômetro de energia dispersiva (ESD) acoplado.

\section{Milonito Granítico}

As barras de argamassa moldadas com agregado milonito granítico com o cimento sem adição apresentaram a maioria dos poros preenchidos com gel esbranquiçado. A Foto 20 e a Foto 21 ilustram as feições características observadas ao microscópio estereoscópico. A Foto 22 ao MEV mostra poro preenchido por gel e a Figura 32 a com composição química típica de produto de RAA. O preenchimento dos poros por produtos de RAA contribui para a redução da porosidade da argamassa.

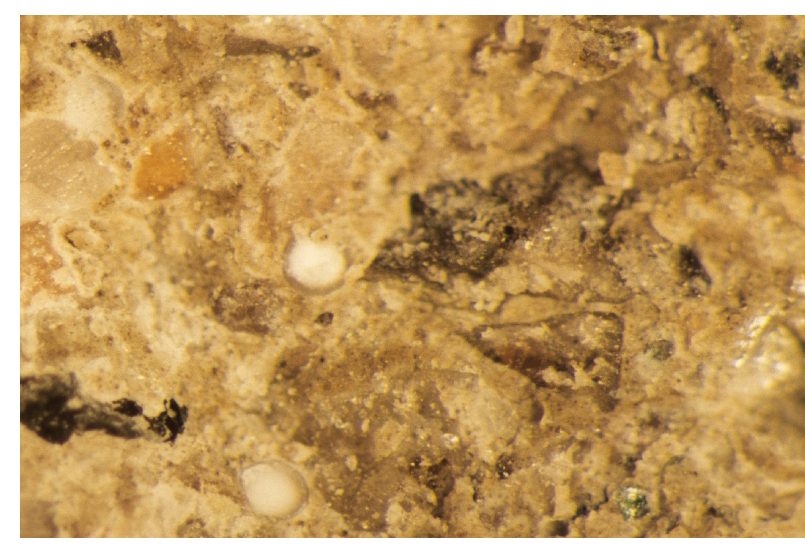

Foto 20 - Aspecto geral da barra de argamassa, em que se observam poros preenchidos com gel esbranquiçado e agregado com borda de reação. Microscópio estereoscópico. Ampliação 10x.

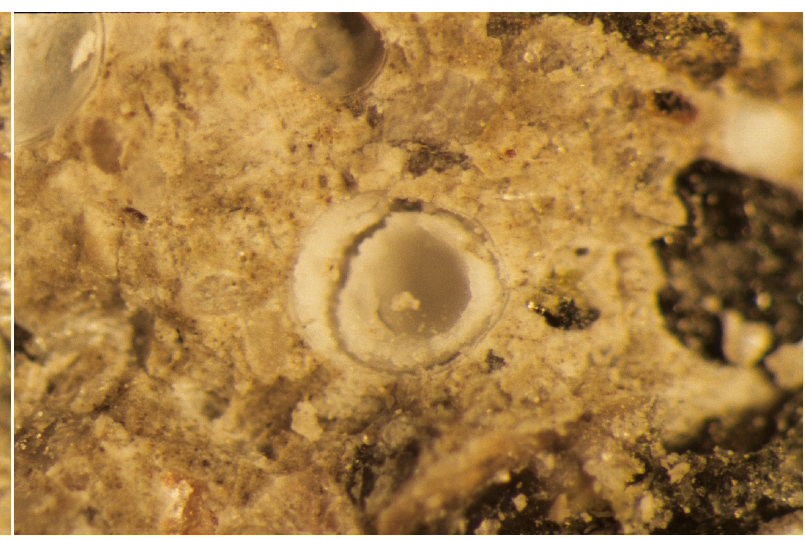

Foto 21 - Poro preenchido com gel esbranquiçado, com formação de anel no contorno do poro. Microscópio estereoscópico Ampliação 20x. 


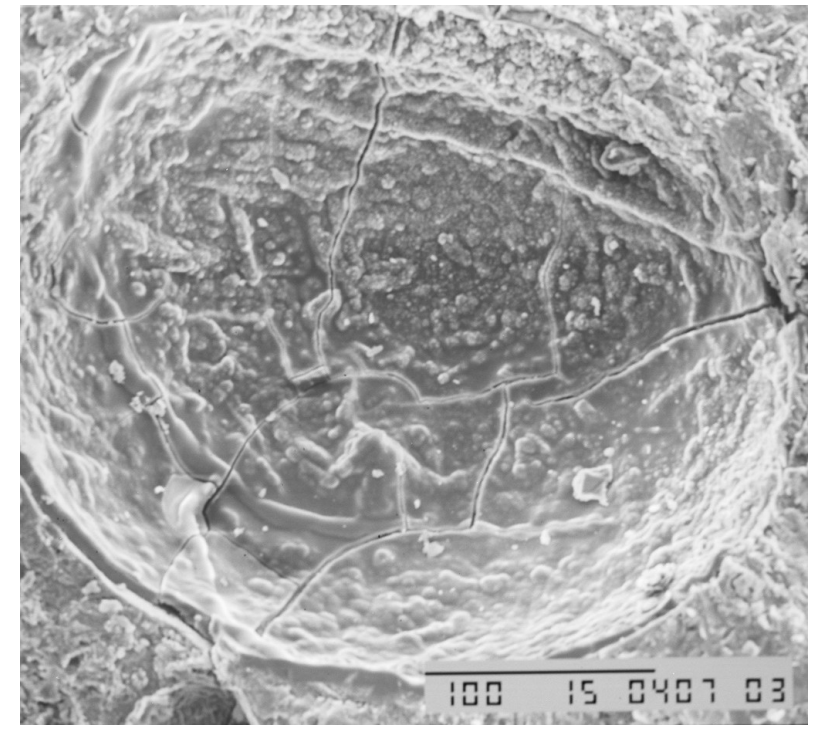

Foto 22 - Detalhe de poro preenchido com gel. MEV ampliação 350x

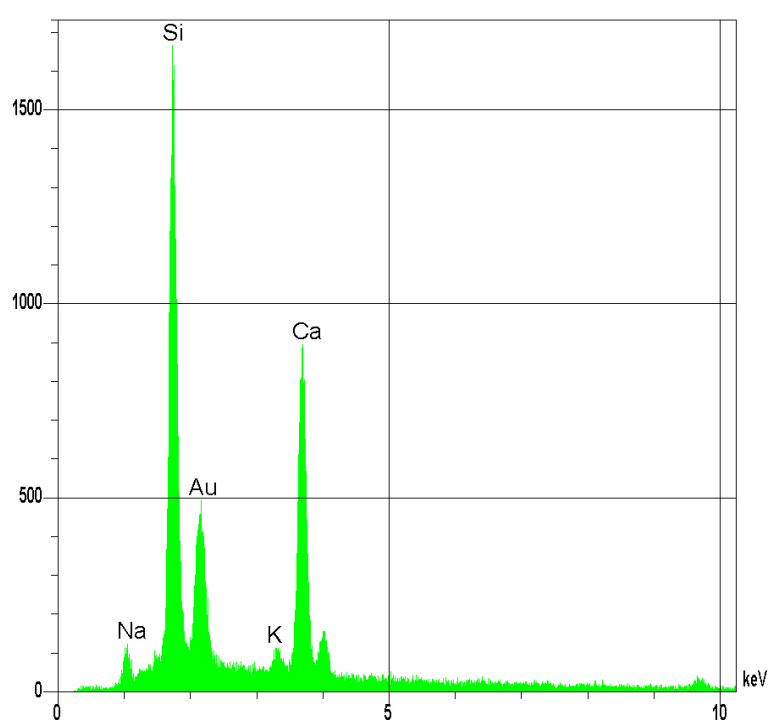

Figura 32 - Espectro de EDS mostrando composição química típica de produtos de RAA.

Observaram-se também poros preenchidos por gel transparente, gelatinoso, que se espalhava sobre a argamassa quando a barra era quebrada. A Foto 23 e a Foto 24 ilustram as feições observadas ao microscópio estereoscópico.

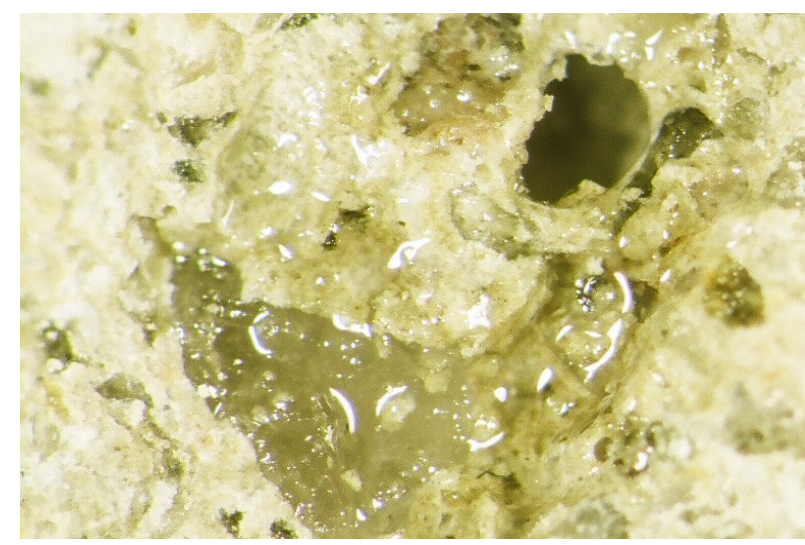

Foto 23 - Poro preenchido com gel transparente e gelatinoso, que se espalhou sobre a argamassa após a quebra da barras. Microscópio estereoscópico. Ampliação 20x.

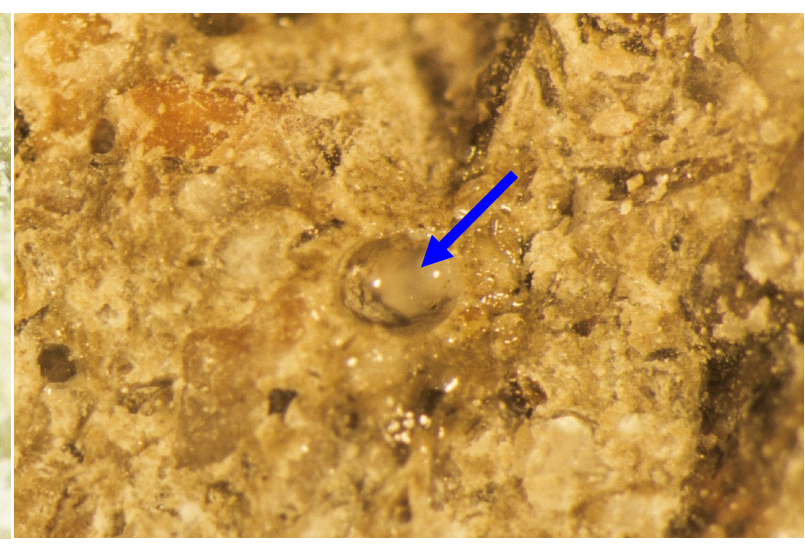

Foto 24 - Poro preenchido com gel transparente e gelatinoso e gel esbranquiçado no fundo do poro. Microscópio estereoscópico. Ampliação $15 x$.

Análises ao MEV revelaram que o material apresenta aspecto maciço com leve gretamento (Foto 25) e é constituído basicamente por sílica e sódio, com pequena quantidade de cálcio (Figura 33). 


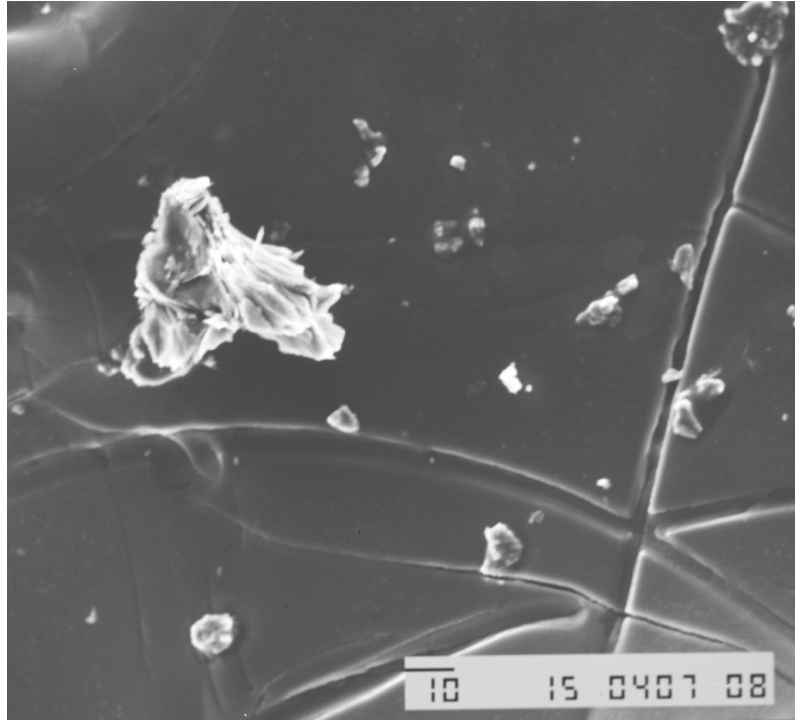

Foto 25 - Aspecto do gel espalhado sobre a argamassa. Apresenta aspecto maciço e com leve gretamento. MEV ampliação 750x.

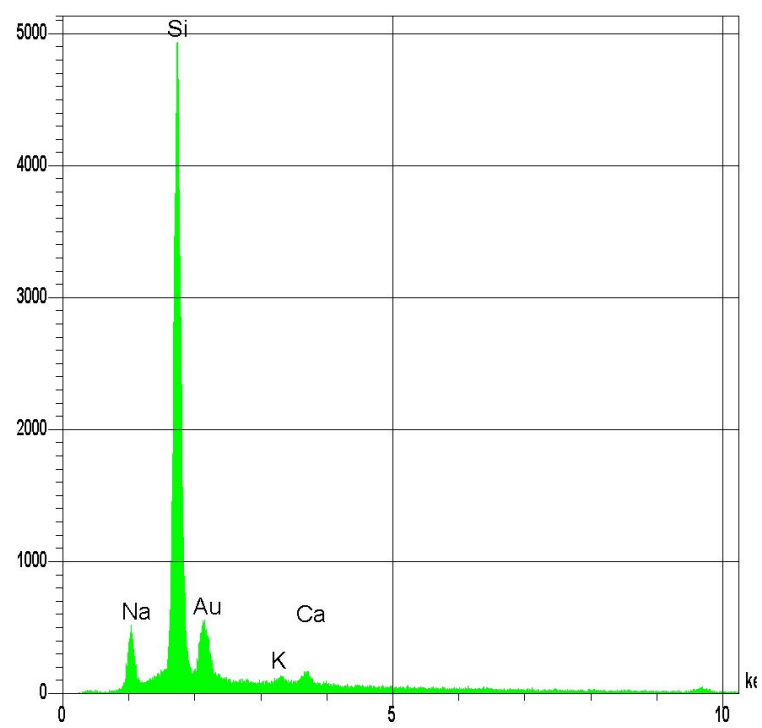

Figura 33 - Espectro de EDS do gel que se espalhou sobre a argamassa.

Observou-se também que os grãos de agregado ficaram fragilizados pela reação, e desagregados facilmente com espátula de aço, como ilustrado na Foto 26 , enquanto nas barras de argamassa moldadas com $35 \%$ de cinza volante, a espátula desagrega apenas a pasta, mas não o grão de quartzo, Foto 27.

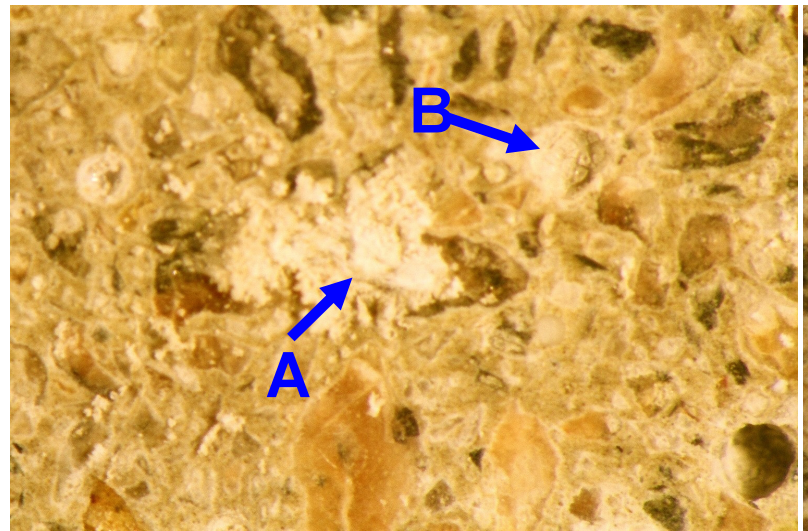

Foto 26 - Argamassa com cimento sem adição. Grão de quartzo desagregado com espátula de aço $(A)$ e poro preenchido com gel esbranquiçado (B). Microscópio estereoscópico. Ampliação 15x.

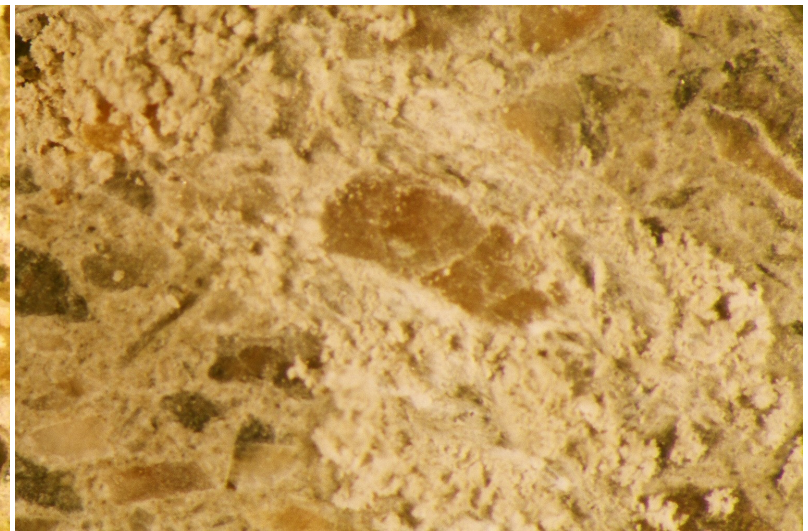

Foto 27 - Argamassa moldada com cimento com $35 \%$ de cinza volante. Grão de quartzo intacto após ser raspado intensamente com espátula de aço enquanto a argamassa, mais frágil, desagregou. Microscópio estereoscópico. Ampliação 20x. 
A fragilização é provavelmente decorrente da reação entre os hidróxidos alcalinos e os cristais de quartzo deformados ou microgranulares. Ensaios realizados ao microscópio óptico de luz transmitida na lâmina delgada da barra de argamassa com cimento sem adição sugerem que a reação ocorreu dentro do grão, separando os cristais de quartzo, que podem ser visualizados sem cruzar os polarizadores, conforme ilustrado na Foto 28. A Foto 29 ilustra grão de agregado com cristais de quartzo "separados" e interligado com poro preenchido com gel. A coloração azulada é devido à impregnação da lâmina com resina durante a preparação.

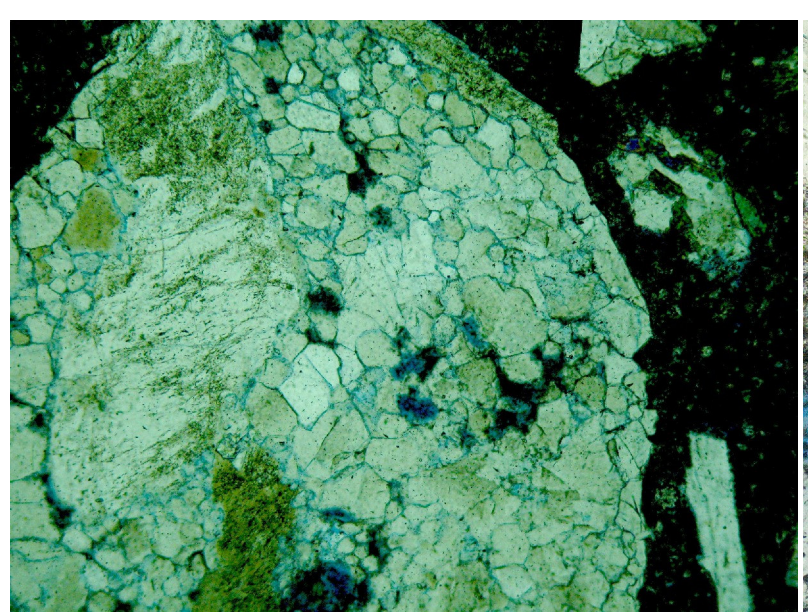

Foto 28 - Grão do agregado milonito granítico no qual se observam cristais de quartzo separados, provavelmente em decorrência da RAA. Microscópio de luz transmitida. Ampliação 25x

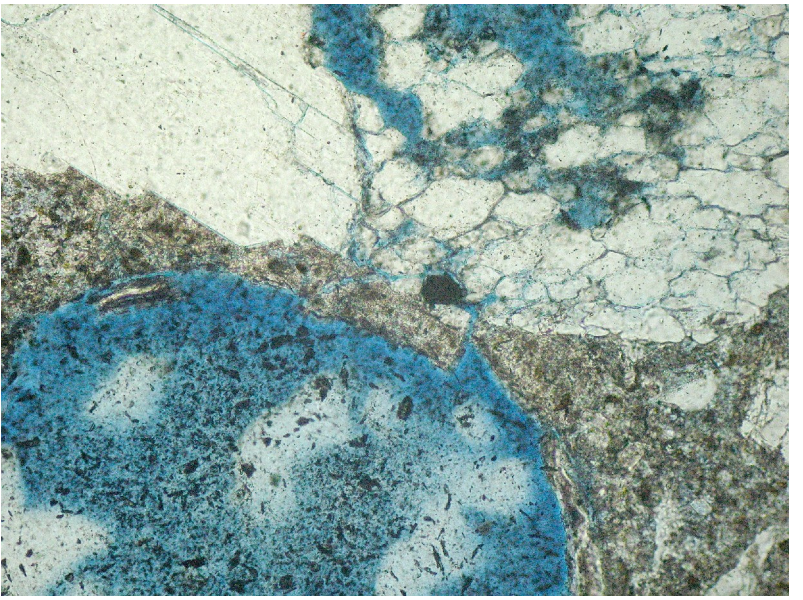

Foto 29 - Grão do agregado milonito granítico com cristais de quartzo "separados" e interligado a poro preenchido por gel. Microscópio de luz transmitida. Ampliação 25x

Ensaios realizados ao MEV confirmaram que a separação dos cristais de quartzo deve-se à formação de produtos de reação álcali-agregado na superfície dos cristais, conforme mostrado na Foto 30 e detalhado na Foto 31. Análise da composição química realizada por microanálise (EDS) detectou a presença de sílica, cálcio e dos álcalis sódio e potássio, confirmando tratar-se de produto de RAA, Figura 34. 


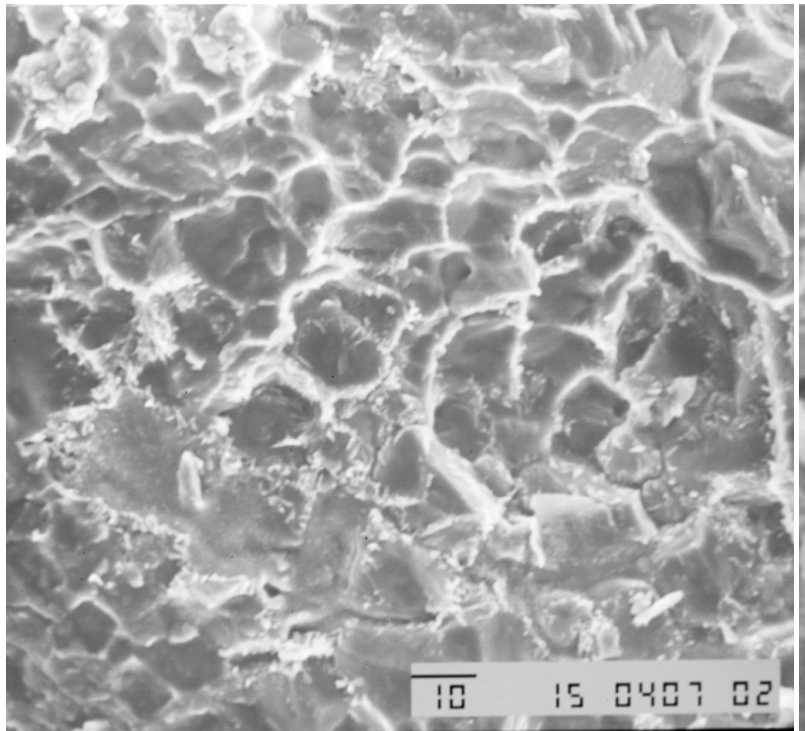

Foto 30 - Aspecto geral de grão do agregado milonito granítico constituído por cristais de quartzo separados por material intersticial. MEV ampliação 1000x.

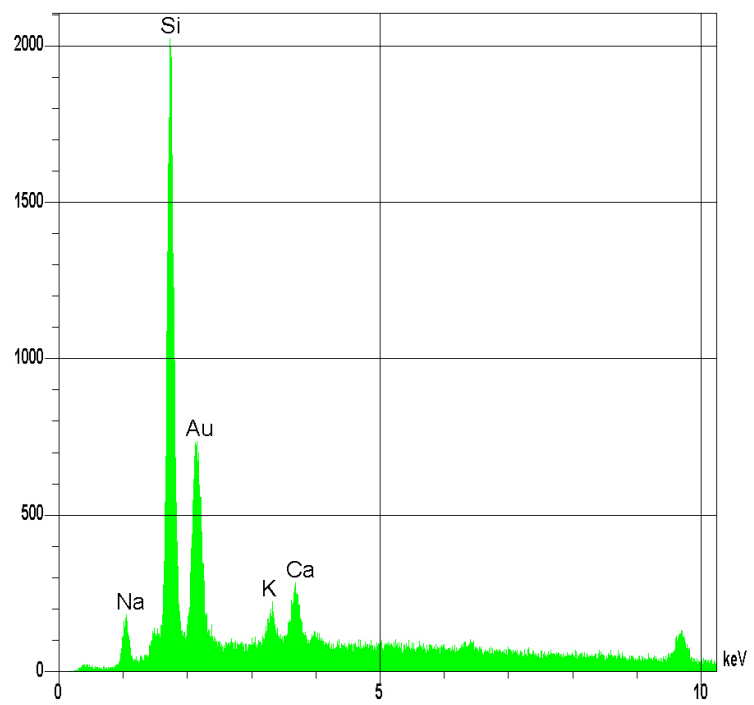

Figura 34 - Espectro da análise da composição do produto da RAA observado entre os cristais de quartzo.

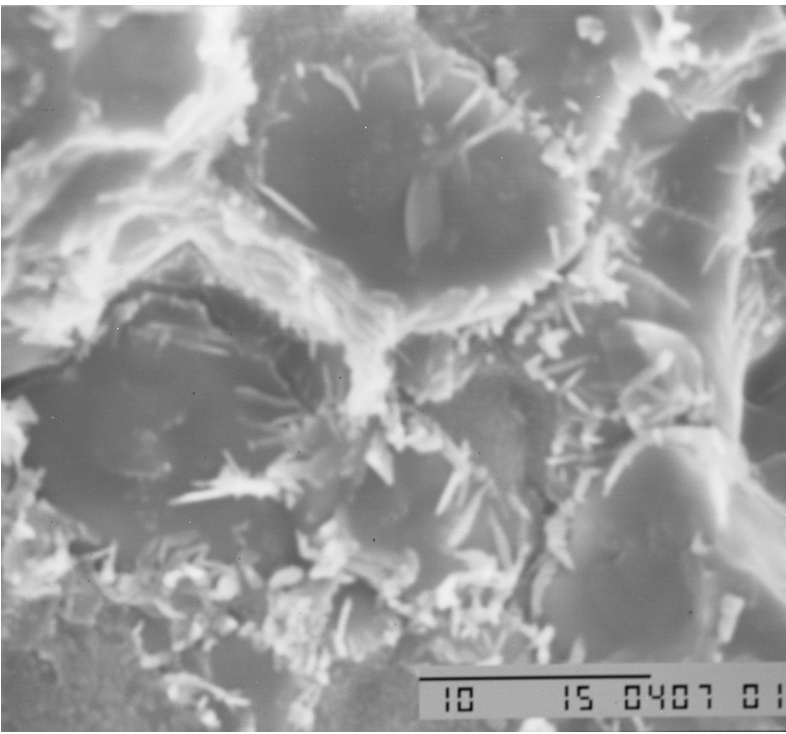

Foto 31 - Detalhe dos cristais de quartzo envolvidos por produto de reação álcaliagregado. MEV ampliação 3500x. 
Produtos cristalizados de RAA formados por sódio são observados ao MEV com aspecto acicular preenchendo poro, conforme mostrado na Foto 32 e na Figura 35. Essa morfologia também foi encontrada recobrindo cristais de quartzo, indicando reação topoquímica na qual não ocorreu a migração para os espaços vazios da argamassa, conforme ilustrado na Foto 33 e na Figura 36.

Feição morfológica similar rica em sódio foi observada em produtos de reação da Barragem de Joanes/BA (Zampieri, Kihara e Scandiuzzi, 1992).

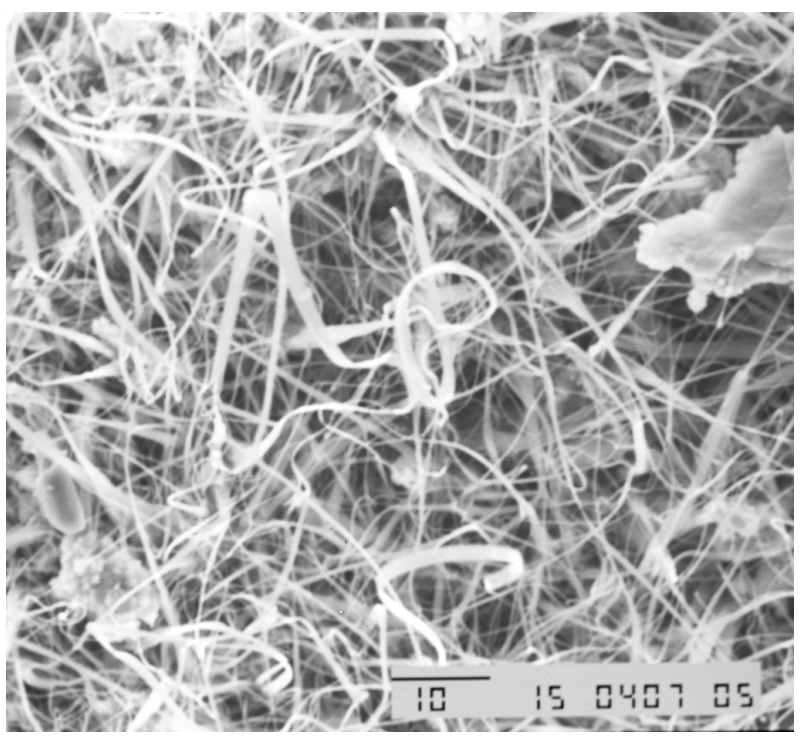

Foto 32 - Poro preenchido por produtos de RAA com aspecto acicular característicos da participação do sódio na reação. MEV ampliação $1500 x$

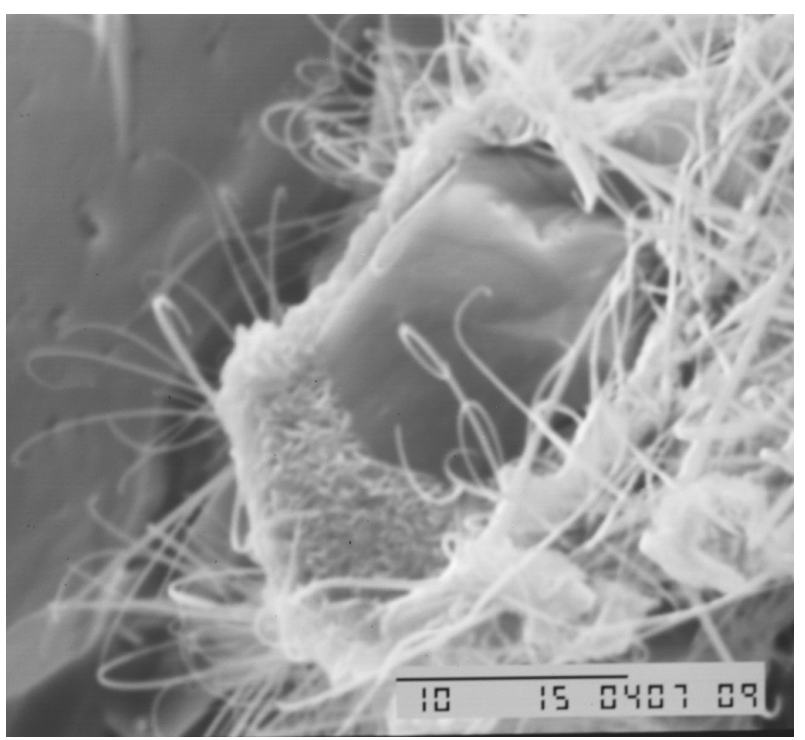

Foto 33 - Cristal de quartzo recoberto por produtos de RAA com aspecto acicular. MEV apliação 3500x.

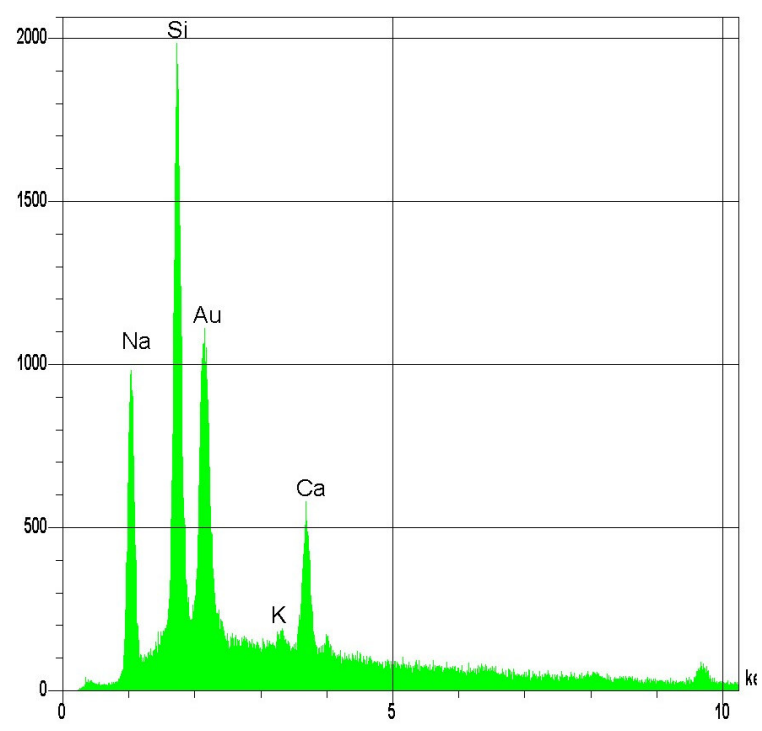

Figura 35 - Espectro de EDS do produto de RAA fibroso formado a partir do sódio.

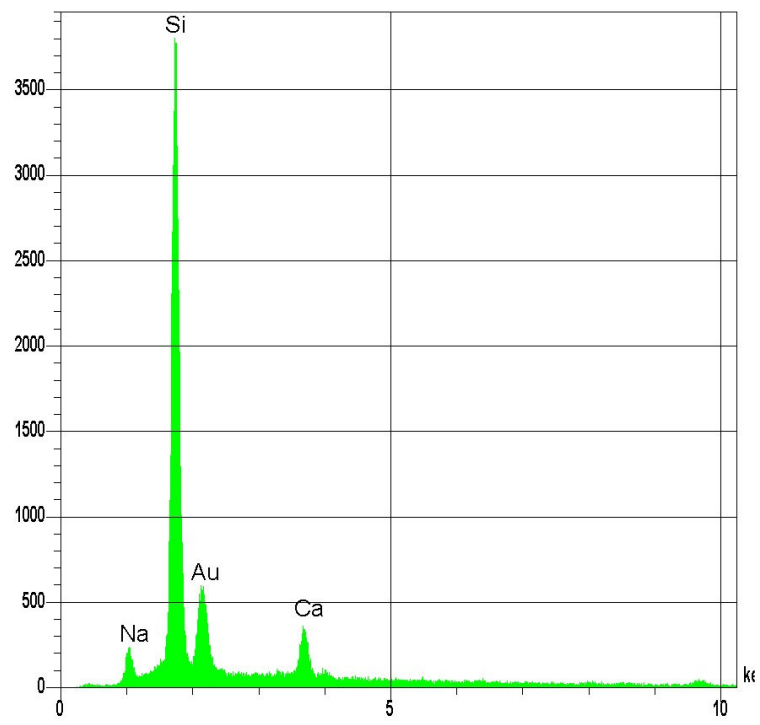

Figura 36 - Espectro de EDS mostrando que os produtos de RAA foram formados com a participação de sódio e cálcio 
O agregado milonito granítico também apresentou como fase reativa o feldspato deformado por esforços tectônicos. A Foto 34 mostra um cristal de feldspato totalmente corroído sugerindo que ele é atacado pelos íons hidroxila, fornecendo ao sistema, além de sílica para a reação álcali-silicato, também álcalis. A Figura 37 apresenta composição química do cristal de feldspato.

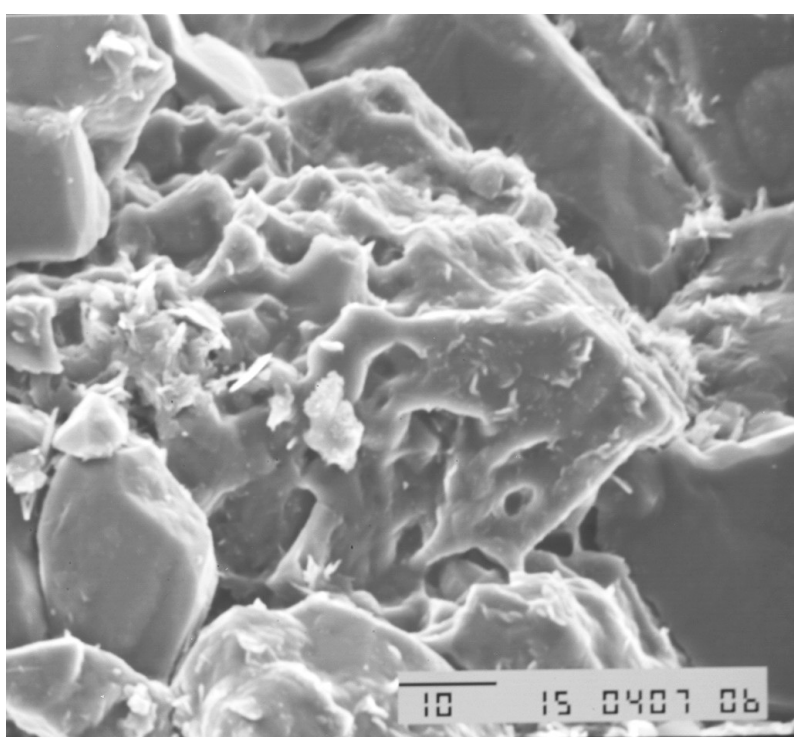

Foto 34 - Cristal de feldspato totalmente corroído provavelmente devido a RAA. MEV ampliação 1500x.

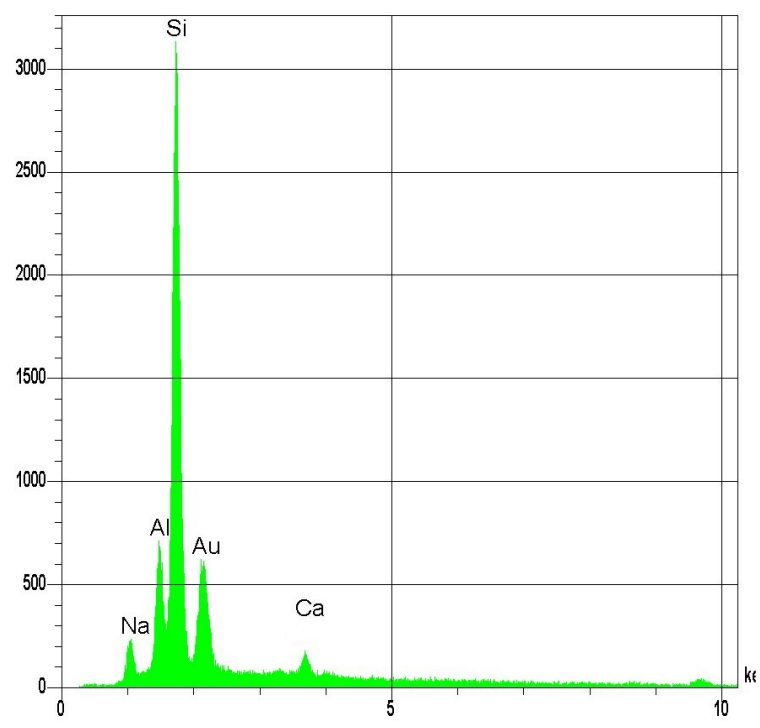

Figura 37 - Espectro de EDS confirmando se tratar de cristal de feldspato

Nas barras moldadas com os cimentos com adições ativas há uma redução gradual dos poros preenchidos com gel e um aumento dos poros vazios. Mesmo nas barras com teor máximo de cada adição observou-se, às vezes, a presença de gel, mas não se observou a fragilização dos grãos nos teores máximos de adição.

Ao MEV observou-se a presença freqüente de gel e de produtos cristalizados de RAA nas barras de argamassa moldadas com cimento com $60 \%$ de escória. Nas barras moldadas com cimento com $35 \%$ de cinza volante os produtos de RAA são bem menos freqüentes. 


\section{Basalto}

As barras moldadas com agregado basalto e cimento sem adição não apresentaram a formação de gel (poros preenchidos) tão acentuada quanto no agregado milonito granítico. Observa-se freqüentemente a presença de gel com aspecto leitoso sobre a superfície do agregado. Essas feições sugerem que o gel da reação álcali-sílica formado é mais viscoso e conseqüentemente apresenta menor mobilidade, não migrando através da pasta e ocupando os espaços vazios. Observou-se com menor freqüência poros preenchidos com gel transparente e gelatinoso. A Foto 35 e a Foto 36 ilustram as feições características observadas nas barras.

A fragilização dos grãos de agregado basalto não é tão intensa quanto do milonito granítico, é mais superficial. Entretanto, são necessários mais estudos para confirmar essas observações.

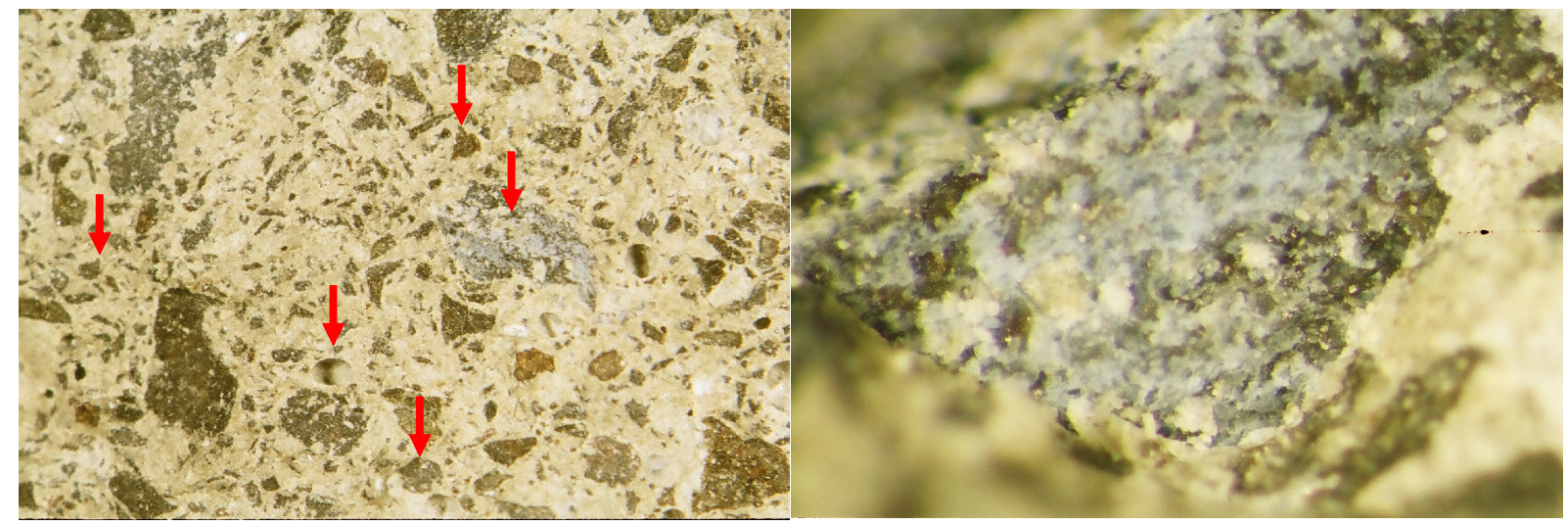

Foto 35 - Vista geral da barra de argamassa Foto 36 - Detalhe de agregado com gel com mostrando poros vazios e gel com aspecto aspecto leitoso sobre a superfície do agregado leitoso sobre o agregado basalto. Microscópio basalto. Microscópio estereoscópico. Ampliação estereoscópico. Ampliação 6x. $30 x$.

Os produtos da reação álcali-sílica do agregado basalto são encontrados preferencialmente sobre a superfície dos agregados, indicando que não migraram do local da reação para os espaços vazios da argamassa. Esses produtos também se diferenciam da reação álcali-silicato do agregado milonito granítico na composição química, pois a maioria dos espetros de EDS dos produtos da reação apresentou alumínio em sua composição. 
A Foto 37 ilustra uma feição representativa dos produtos da reação sobre a superfície dos grãos de agregado e a Figura 38 mostra que o produto é constituído por sílica, alumínio, potássio, sódio e cálcio. Observou-se também a presença de gel gretado com composição similar ao gel da reação álcali-silicato do agregado milonito granítico, conforme ilustrado na Foto 38 e na Figura 39.

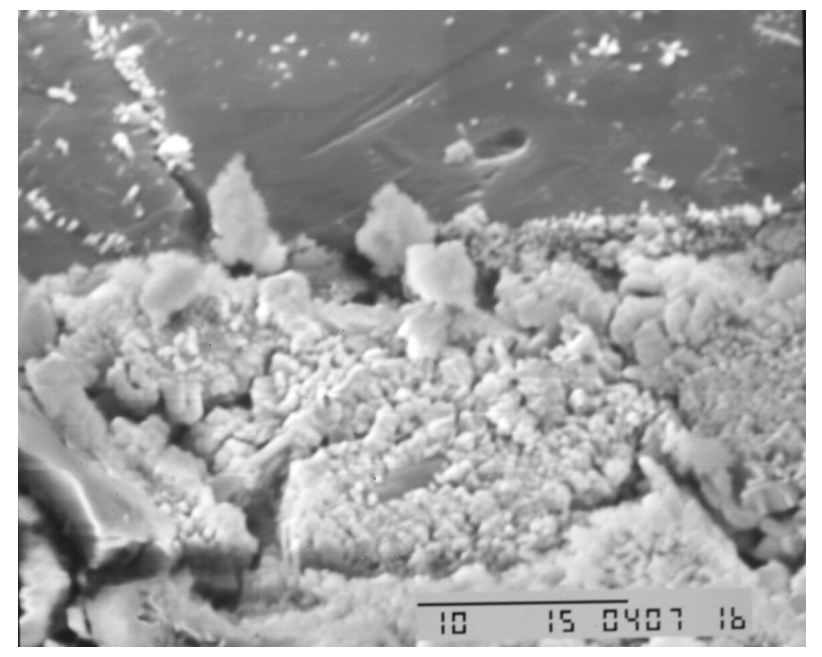

Foto 37 - Produtos de reação álcali-sílica sobre a superfície de um cristal de feldspato. MEV ampliação 3500x.

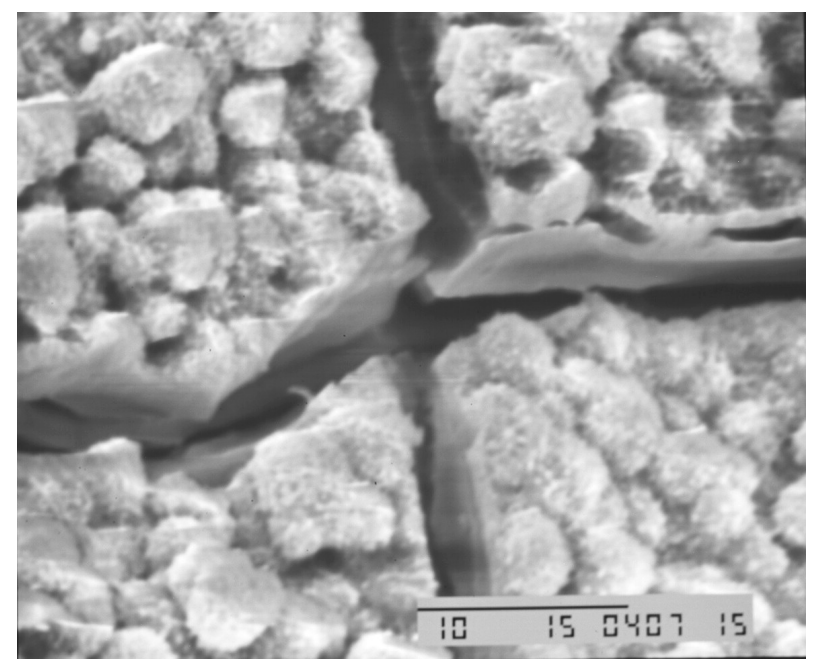

Foto 38 - Gel gretado com produtos cristalizados sobre a superfície. MEV ampliação 3500x.

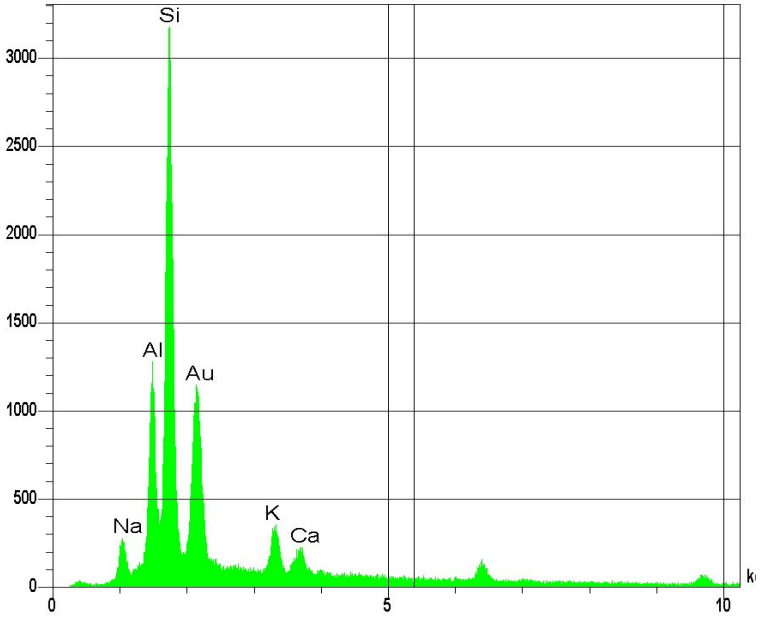

Figura 38 - Espectro de EDS representativo da composição química do produto da reação álcali-sílica encontrado sobre a superfície dos grãos de basalto.

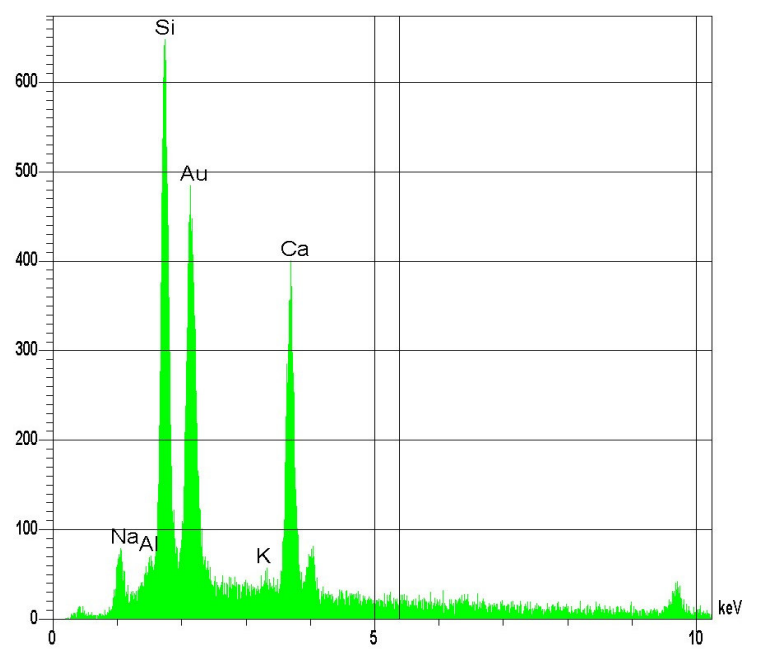

Figura 39 - Espectro de EDS mostrado composição similar aos produtos da reação álcali-silicato do agregado milonito granítico. 


\section{ANÁLISE DOS RESULTADOS}

\section{> Avaliação da eficiência das adições ativas na minimização da RAA.}

A Figura 40 e a Figura 41 apresentam os resultados da expansão aos 14 e 28 dias de cura em solução alcalina das amostras de milonito granítico e basalto, respectivamente, combinadas com os cimentos com adição em teores crescentes de escória de alto-forno $(A)$, cinza volante (B), metacaulim (C) e sílica ativa (D).

Com base nos resultados obtidos podem-se tecer as seguintes considerações:

A expansão das barras de argamassa é reduzida sistematicamente com aumento do teor de adição ativa nos cimentos experimentais e à medida que o teor de adição aumenta a diferença de expansão entre 14 e 28 dias diminui.

Os perfis dos materiais pozolânicos são semelhantes indicando analogia de mecanismo de reação, diminuindo mais rapidamente, provavelmente pela influência da reação pozolânica.

O teor mínimo de adição para mitigar a expansão causada pela reação álcalisilicato da amostra de milonito granítico para valores inferiores a 0,10\% aos 14 dias de cura em solução alcalina é de:

- $60 \%$ escória de alto-forno

- $16 \%$ de cinza volante

- $15 \%$ metacaulim

- $10 \%$ sílica ativa

$>$ O teor mínimo de adição para mitigar a expansão causada pela reação álcalisílica da amostra de basalto para valores inferiores a 0,10\% aos 14 dias de cura em solução alcalina é de:
- $45 \%$ escória de alto-forno
- $20 \%$ de cinza volante
- $13 \%$ metacaulim
- $9 \%$ sílica ativa 


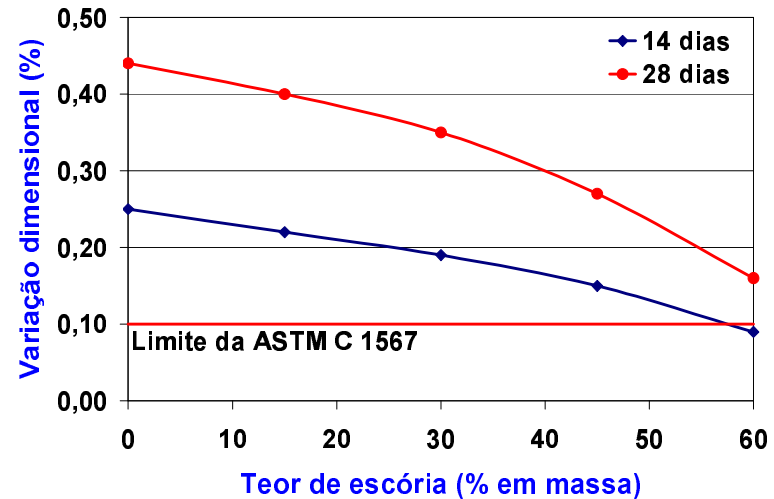

A

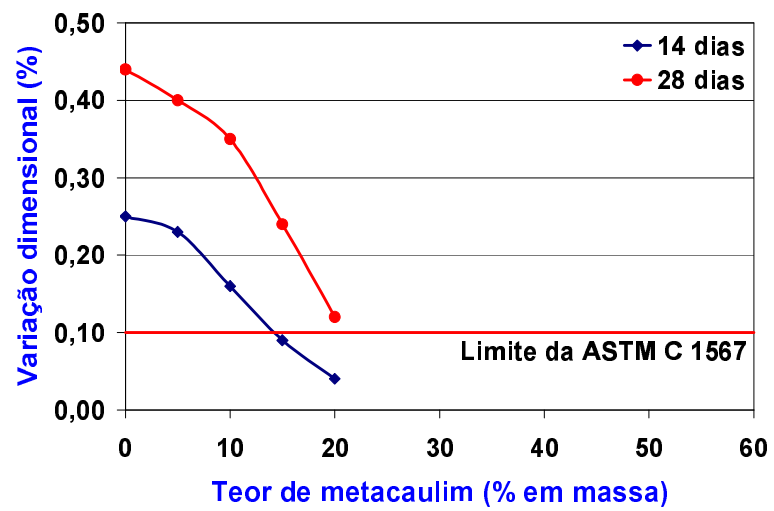

C

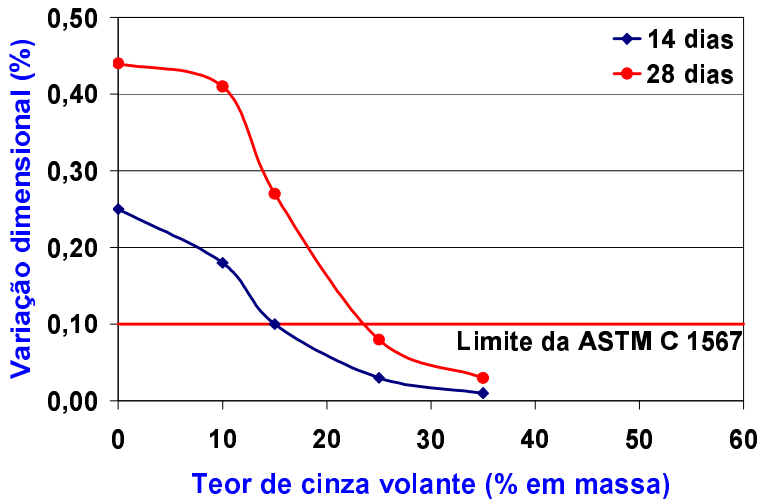

B

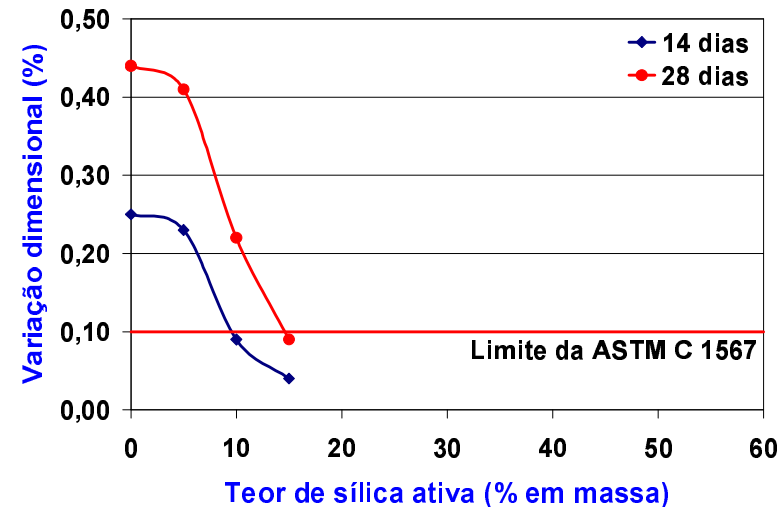

D

Figura 40 - llustra a redução da expansão do agregado milonito granítico quando combinado com cimentos com adição de escória, cinza volante, metacaulim e sílica ativa
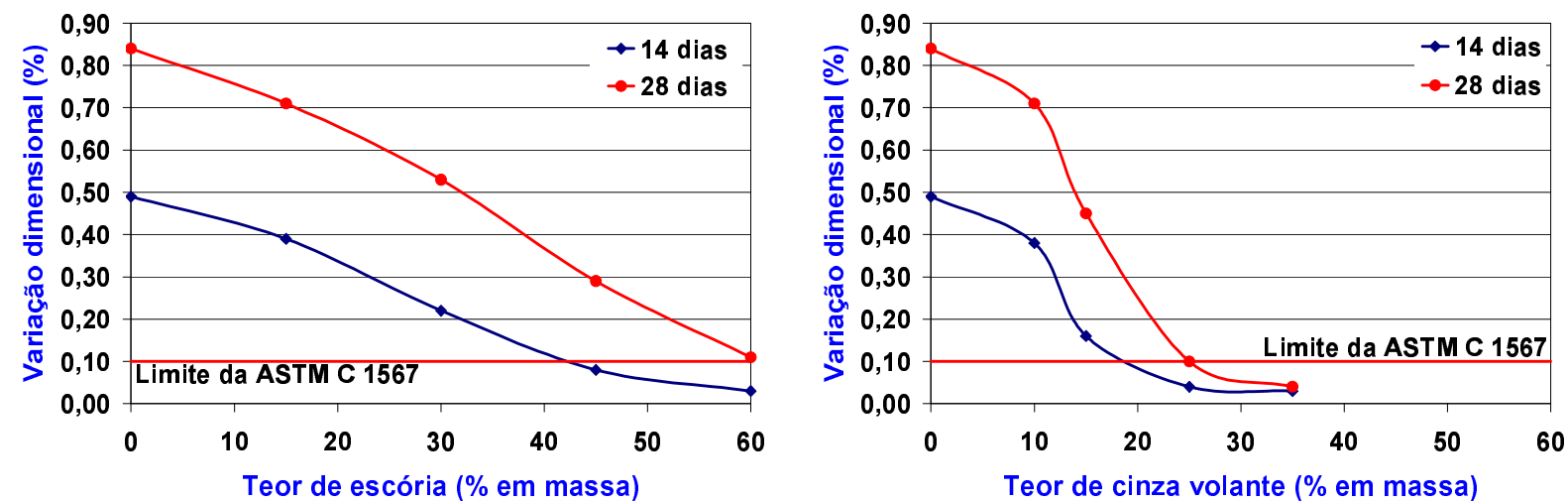

A

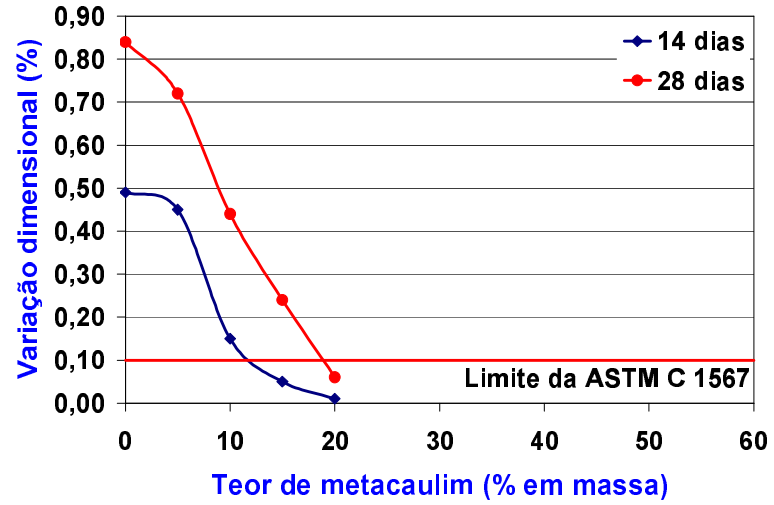

C

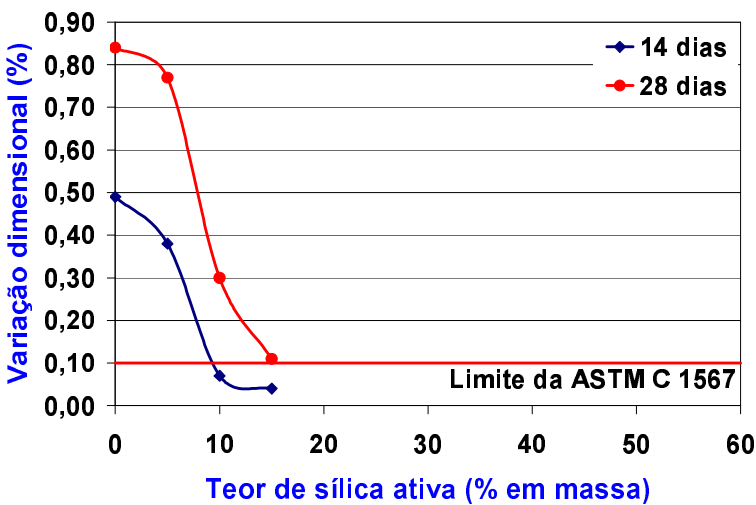

D

Figura 41 - llustra a redução da expansão do agregado basalto quando combinado com cimentos com adição de escória, cinza volante, metacaulim e sílica ativa 
A Figura 42 apresenta os resultados da expansão aos 14 dias de cura em solução alcalina das amostras de milonito granítico e basalto combinadas com os cimentos com teores crescentes de adição de escória de alto-forno (A), cinza volante (B), metacaulim (C) e sílica ativa (D).

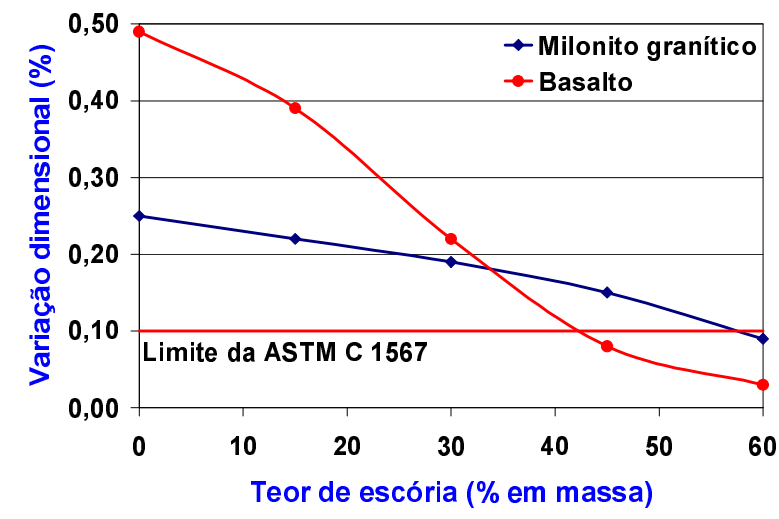

A

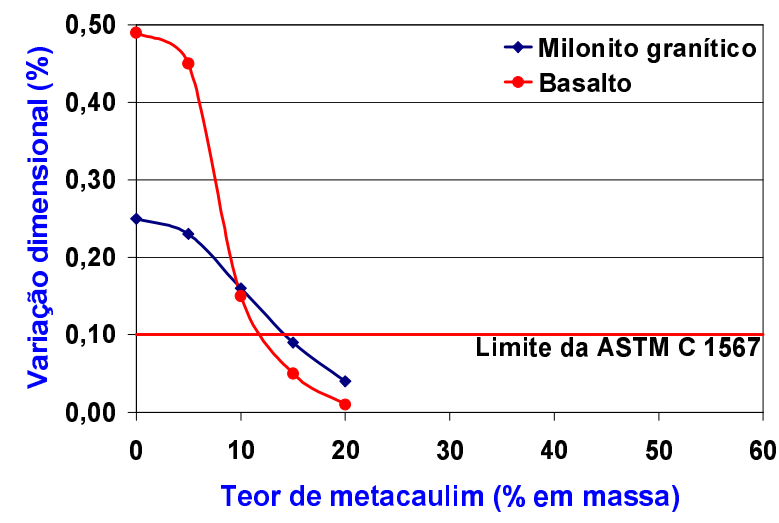

C

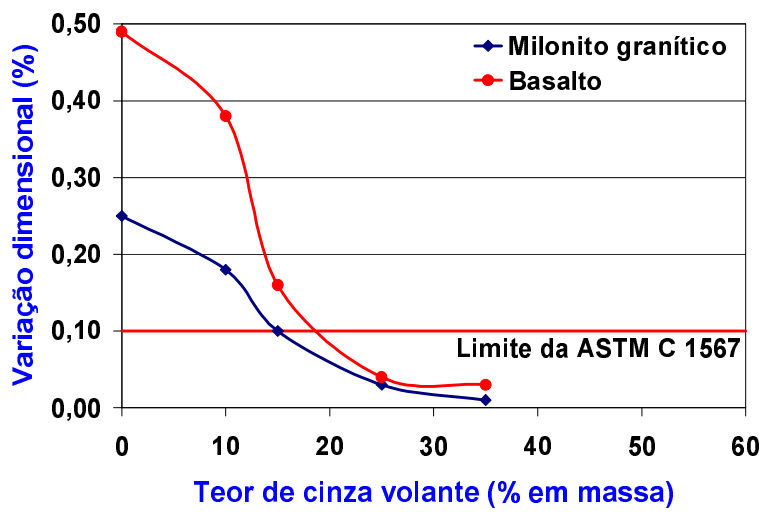

B

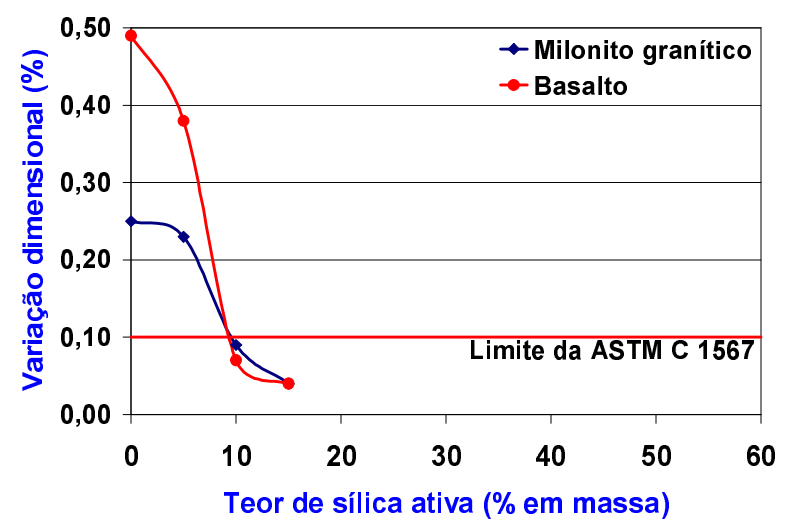

$\mathrm{D}$

Figura 42 - llustra a eficiência dos cimentos com adição de escória de alto-forno, cinza volante, metacaulim e sílica ativa em reduzir a expansão dos agregados milonito granítico e basalto.

Embora a expansão inicial do basalto seja o dobro da expansão do milonito granítico aos 14 dias de cura em solução alcalina com o cimento sem adição, observa-se que as adições são mais eficientes na minimização da expansão do basalto que produz o tipo de reação álcali-sílica em relação ao milonito granítico que produz reação tipo álcali-silicato.

Com base nos valores de expansão obtidos com os cimentos experimentais com $15 \%$ de adição, comum a todos, verifica-se que a sílica ativa é a mais eficiente na minimização das reações álcali-silicato e álcali-sílica, seguida pelo metacaulim e cinza volante. 
Essa mesma ordem também foi obtida na determinação do teor de hidróxido de cálcio das barras, sugerindo que $\mathrm{O} \mathrm{Ca}(\mathrm{OH})_{2}$ desempenha papel importante na expansão da RAA.

Dentre as adições ativas investigadas a escória de alto-forno é a menos eficiente, pois é necessário teores de adição até seis vezes maiores que o da sílica ativa para obter o mesmo grau de eficiência. Metacaulim e cinza volante apresentaram desempenho semelhante na minimização da reação álcali-silicato (milonito granítico), mas o metacaulim foi o mais eficiente na minimização da reação álcalisílica (basalto). A sílica ativa mostrou-se a mais eficiente, pois o teor de apenas 10\% mitigou a expansão para os níveis aceitáveis.

A menor eficiência da escória de alto-forno, quando comparada as outras adições em igualdade de teor no cimento portland, está relacionada provavelmente à sua composição química, cujo teor de cálcio é maior em relação as outras adições, sendo necessário, portanto, maiores teores de adição para reduzir a relação $\mathrm{CaO} / \mathrm{SiO}_{2}$ dos aglomerantes. O teor de hidróxido de cálcio nas barras de argamassa foi reduzido principalmente em função da diluição do clínquer Portland.

O desempenho da escória em mitigar a RAA pode ter sido agravado no ensaio acelerado devido à ativação térmica e química, o que proporcionou ao sistema maior quantidade de produtos hidratados e, conseqüentemente, preencheu os espaços vazios da pasta, reduzindo assim os poros que podem atuar como minimizadores das tensões. Como a porosidade total foi reduzida, os produtos da reação podem exercer uma maior pressão na pasta, contribuindo assim para o aumento da expansão, que é o parâmetro utilizado para avaliar a eficiência das adições.

Considerando-se que a expansão deve ser inferior a 0,10\% aos 14 dias de cura em solução alcalina, calculou-se que as adições deveriam reduzir a expansão em pelo menos 64\% e 82\%, em relação ao cimento sem adição, para as amostras de milonito granítico e basalto, respectivamente. A Figura 43 apresenta a redução da expansão em porcentagem aos 14 dias de cura em solução alcalina do agregado milonito granítico e a Figura 44 do basalto. 


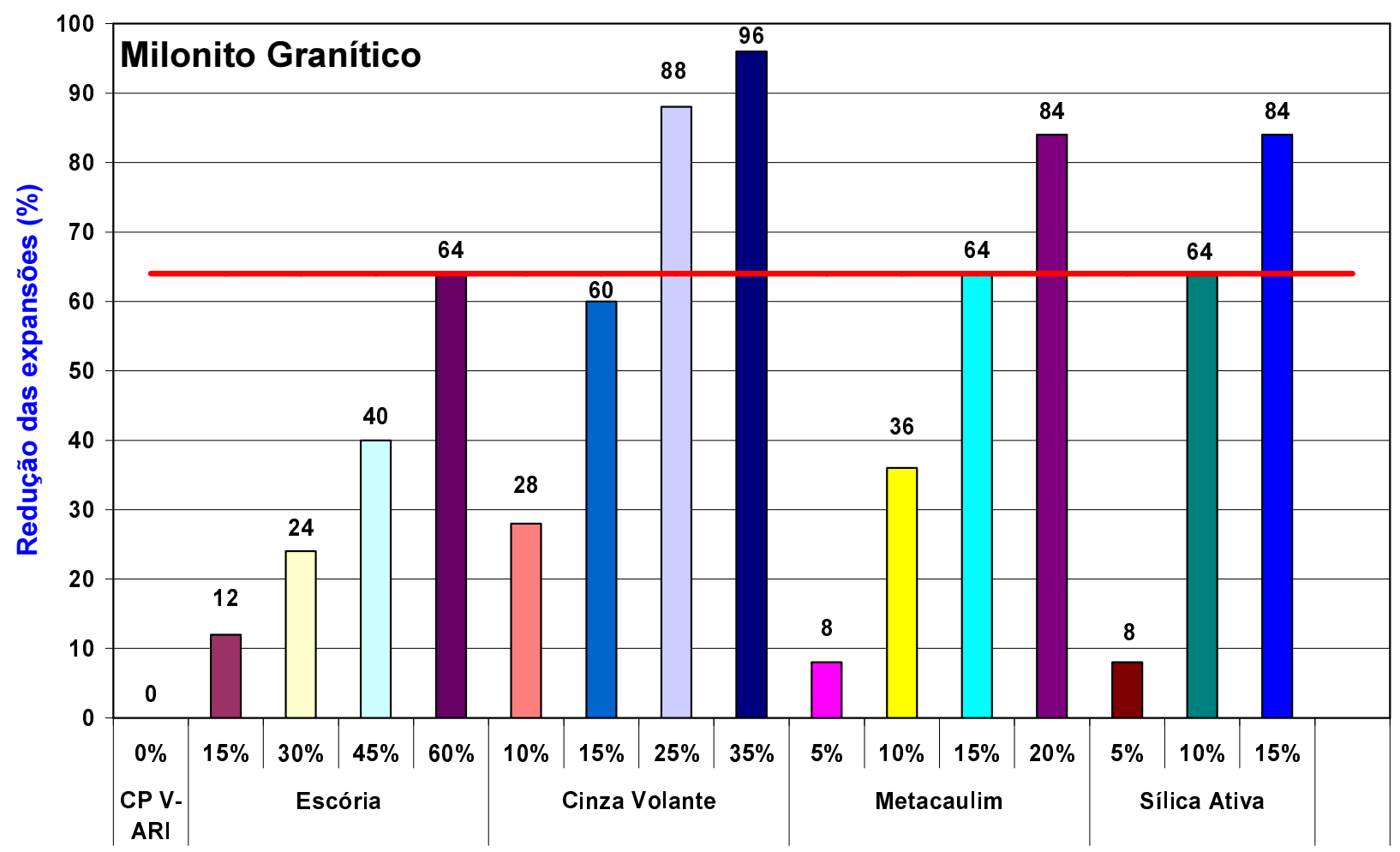

Figura 43 - Ilustra a redução da expansão em porcentagem do agregado milonito granítico quando combinado com cimentos com adição de escória de alto-forno, cinza volante, metacaulim e sílica ativa.

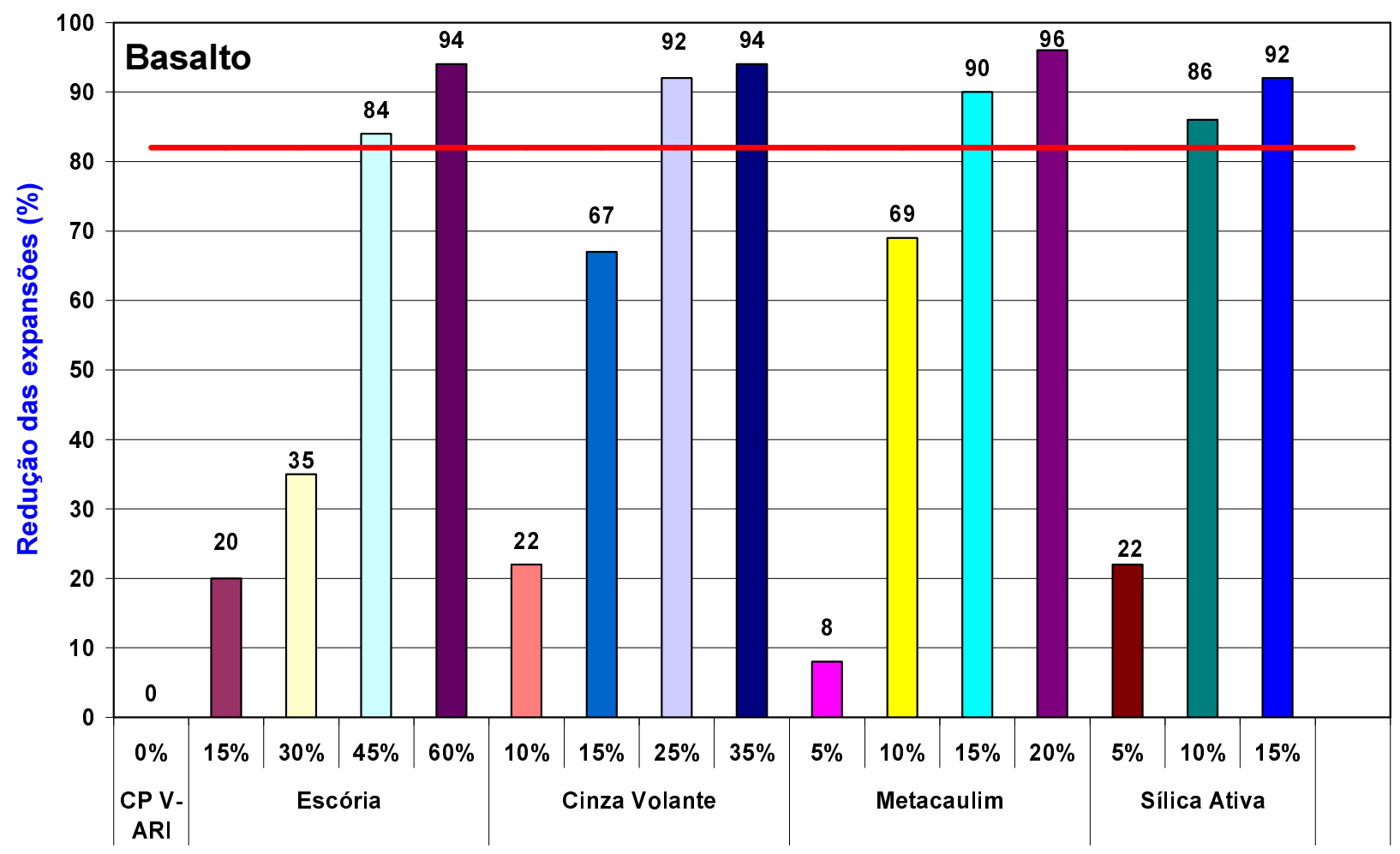

Figura 44 - llustra a redução da expansão em porcentagem do agregado basalto quando combinado com cimentos com adição de escória de alto-forno, cinza volante, metacaulim e sílica ativa. 
Das teorias elaboradas para explicar a minimização da reação álcali-agregado com as adições ativas destacam-se: a diluição dos álcalis do cimento, retenção dos álcalis na estrutura do C-S-H, redução da permeabilidade e redução do $\mathrm{pH}$. Todas elas podem ser válidas e aplicáveis em estruturas de concreto em campo.

No ensaio acelerado das barras de argamassa em solução alcalina $1 \mathrm{~N}$ de $\mathrm{NaOH}$ a 80ํㅡ nenhuma dessas teorias se aplica, pois há uma fonte inesgotável de álcalis, que compensará a diluição dos álcalis do cimento, e a capacidade de retenção dos álcalis pelo C-S-H é limitada. Embora haja um refinamento do tamanho dos poros pelas adições ativas e uma redução da permeabilidade, os álcalis continuam migrando da solução para as barras em função das diferenças de concentração. Conseqüentemente, a redução do $\mathrm{pH}$ em função do consumo do $\mathrm{Ca}(\mathrm{OH})_{2}$ pelas reações pozolânicas será compensada pela solução alcalina que manterá o pH alto dentro das barras.

A expansão das barras de argamassa é reduzida sistematicamente com aumento do teor de adição ativa nos cimentos experimentais, em ambiente que há disponibilidade inesgotável de álcalis. Nenhuma das teorias acima explica essa redução.

Nesse caso, o papel das adições ativas em mitigar a RAA está provavelmente relacionado, num primeiro momento, à diluição, não dos álcalis, mas, sim, do cálcio proveniente do clínquer Portland, que refletirá na relação $\mathrm{CaO} / \mathrm{SiO}_{2}$ dos aglomerantes. Num segundo momento, à redução do teor de $\mathrm{Ca}(\mathrm{OH})_{2}$ durante as reações de hidratação do cimento através das reações pozolânicas.

A Figura 45 mostra que a expansão dos agregados milonito granítico e basalto é reduzida gradativamente à medida que diminui a relação $\mathrm{CaO} / \mathrm{SiO}_{2}$ dos cimentos experimentais com adição de escória de alto-forno, cinza volante, metacaulim e sílica ativa. 


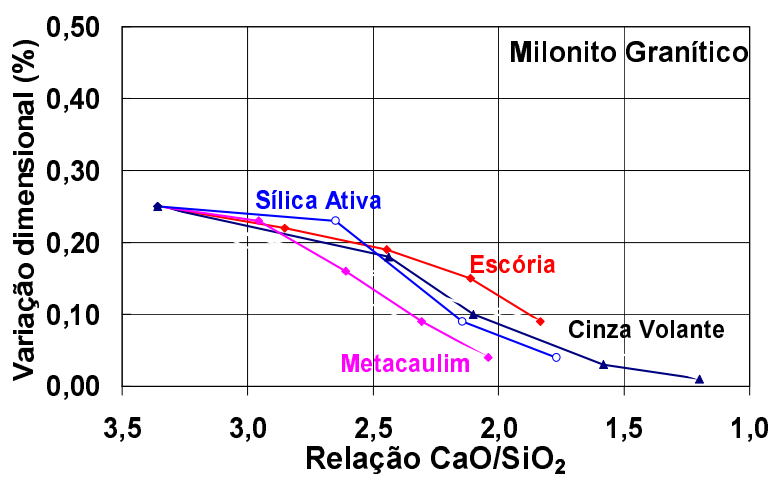

A

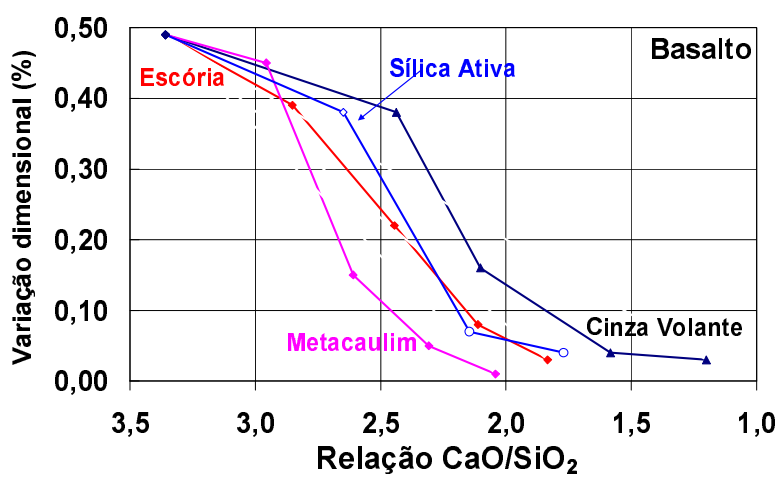

$B$

Figura 45 - Mostra a redução da expansão dos agregados milonito granítico $(A)$ e basalto (B) à medida que a relação $\mathrm{CaO} / \mathrm{SiO}_{2}$ dos cimentos experimentais diminui.

Conseqüentemente o teor de $\mathrm{Ca}(\mathrm{OH})_{2}$ diminui gradativamente com aumento do teor de adição nos cimentos experimentais, refletindo na redução da expansão dos agregados. A Figura 46 mostra que a expansão é reduzida à medida que o teor de hidróxido de cálcio diminui. Os resultados obtidos sugerem que quando o teor de $\mathrm{Ca}(\mathrm{OH})_{2}$ for inferior a $1 \%$ na argamassa a RAA estará em níveis aceitáveis, independente do tipo de adição.

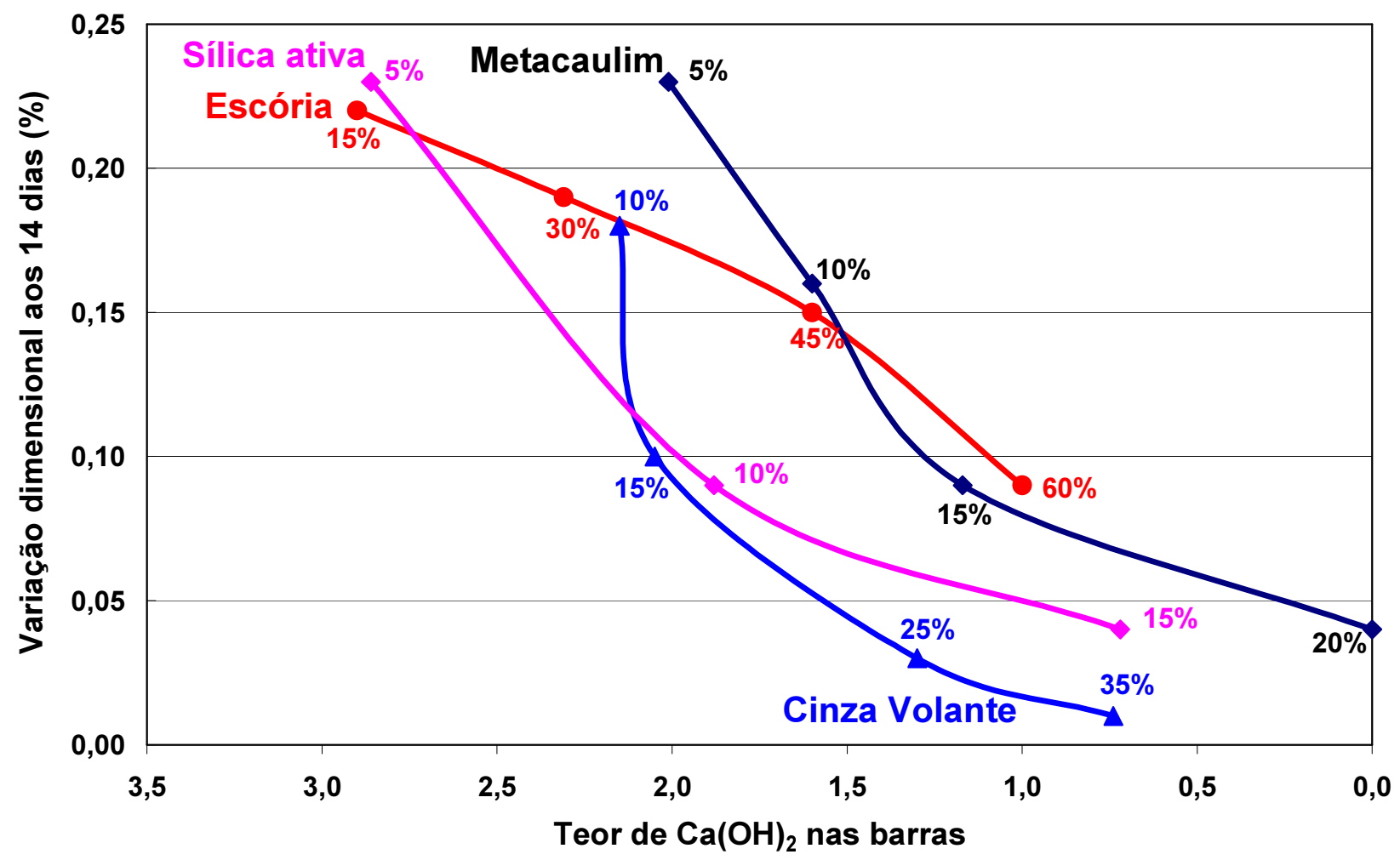

Figura 46 - Redução da expansão em função do teor de hidróxido de cálcio 


\section{CONSIDERAÇÕES FINAIS}

Os dois agregados analisados, basalto e milonito granítico, são potencialmente reativos com os hidróxidos alcalinos. Vidro, clorofeíta, calcedônia (sílica criptocristalina), presentes no basalto, deram origem à reação do tipo álcali-sílica. As fases reativas quartzo microgranular, recristalizado, com extinção ondulante e cristais de quartzo e feldspato deformados, do milonito granítico, por sua vez, deram origem ao tipo de reação álcali-silicato.

As reações álcali-sílica e álcali-silicato apresentaram cinéticas diferentes aos ensaios acelerados em barras de argamassa, que estão relacionadas ao estado termodinâmico da sílica.

As fases reativas do basalto são preferencialmente vítreas e amorfas, reagem rapidamente com os hidróxidos alcalinos em função da alta energia interna. Já no milonito granítico, as fases reativas são cristalizadas, as estruturas cristalinas do quartzo e feldspato são desordenadas devido a esforços tectônicos, o que thes conferiu reatividade com os hidróxidos alcalinos da solução dos poros. O basalto apresentou o dobro da expansão do milonito granítico aos 14 dias de cura.

Além da cinética da reação, o produto da RAA também difere na composição química e na mobilidade. $O$ produto da reação predominante no agregado milonito granítico é formado por sílica, sódio e cálcio. O produto da reação no basalto apresenta composição diferenciada, com a presença de alumínio e pouco cálcio. As feições microtexturais sugerem que a mobilidade do gel da reação álcali-silicato é maior, pois quase todos os poros estão preenchidos por gel gretado. Já o gel da reação álcali-sílica é encontrado preferencialmente na superfície dos grãos, o que sugere maior viscosidade e menor mobilidade.

Produtos cristalizados da reação álcali-silicato também foram encontrados dentro dos grãos de agregado, sugerindo que $\mathrm{Na}^{+}, \mathrm{K}^{+}, \mathrm{Ca}^{++} \mathrm{OH}^{-}$penetraram no grão e reagiram com a sílica. A reação rompeu as ligações químicas dos silicatos e tornou frágil a estrutura dos grãos. Os cristais de feldspato também parecem ter sido atacados pelos íons hidroxila. 
Todas as adições ativas testadas contribuíram para mitigar a reação álcaliagregado, mas a eficiência variou de acordo com a composição química e mineralógica e sua proporção no cimento, e também com o grau de reatividade do agregado e com o tipo de reação. A sílica ativa foi a mais eficiente na minimização das reações álcali-silicato e álcali-sílica, seguida pelo metacaulim, cinza volante e escória de alto-forno.

Os teores mínimos para mitigar a expansão dos agregados analisados foram de $10 \%$ e $15 \%$, de sílica ativa e metacaulim, respectivamente. Esse desempenho está provavelmente relacionado à composição química dos materiais e ao diâmetro das partículas, que conferem alta reatividade pozolânica, reduzem de forma acentuada o teor de hidróxido de cálcio da argamassa e favorecem a minimização da RAA.

No caso da escória de alto-forno, são necessários maiores teores para reduzir a relação $\mathrm{CaO} / \mathrm{SiO}_{2}$ dos aglomerantes e o teor de $\mathrm{Ca}(\mathrm{OH})_{2}$ da argamassa após as reações de hidratação. A menor eficiência dessa adição está relacionada à sua composição química, cujo teor de cálcio é maior do que o de outras adições. O pior desempenho da escória em mitigar a RAA pode ter sido agravado no ensaio acelerado devido à ativação térmica e química.

$\mathrm{O}$ teor pouco expressivo de $\mathrm{K}_{2} \mathrm{O}$ solúvel das barras de argamassa indica que a maior parte deste álcali proveniente dos cimentos está presente no produto da reação álcali-agregado. $\mathrm{O} \quad \mathrm{Na}_{2} \mathrm{O}$ solúvel determinado nas barras de argamassa provém essencialmente da solução alcalina. Há assim uma disponibilidade inesgotável de álcalis e, conseqüentemente, de íons hidroxila necessários à reação. A menor permeabilidade da argamassa conferida pelas adições não foi suficiente para reduzir o ingresso de íons $\mathrm{Na}^{+}$da solução para o interior da barra.

A minimização da expansão está relacionada à redução do teor de hidróxido de cálcio na argamassa, que diminuiu com o aumento do teor de adição ativa no cimento.

Diante dos resultados, conclui-se que esses agregados, quando usados em obras de engenharia civil, devem ser adequadamente combinados a cimentos com adições ativas. 


\section{Linhas futuras de pesquisa:}

A presente pesquisa indicou que o hidróxido de cálcio desempenha papel fundamental na minimização da reação álcali-agregado. No entanto, os fatores pelos quais a expansão das barras de argamassa no ensaio acelerado é mitigada, quando da utilização de adições ativas em ambiente com disponibilidade de álcalis inesgotável, devem continuar sendo investigados para melhor compreensão de seus mecanismos.

Desta forma, é importante que seja determinada a concentração de íons hidroxila na solução dos poros das barras de argamassa moldadas com as adições de escória de alto-forno, cinza-volante, metacaulim e sílica ativa nos diversos teores, e confrontar com os resultados obtidos.

Outra linha de pesquisa poderá investigar a influência da permeabilidade e da porosidade na minimização da expansão.

Por outro lado, para validar o ensaio acelerado das barras de argamassa, pode-se determinar sua correlação com o ensaio de longa duração em prismas de concreto para todas as combinações cimento:agregado investigadas no presente trabalho. 


\section{BIBLIOGRAFIA}

ACI COMMITTEE 221. ACI 221.1R-98. State-of-the-art: Report on alkali-aggregate reactivity. Farmington Hills, Michigan: American Concrete Institute, p.1-31, 1998.

ALVES, E. F. R. et al. Ensaios acelerados em testemunhos de concreto. In: SIMPÓSIO SOBRE REATIVIDADE ÁLCALI-AGREGADO EM ESTRUTURAS DE CONCRETO, 1997, Goiânia. Anais...Goiânia: CBGB/FURNAS, 1997, p. 103-109.

ANDRADE, N. P. H. et al. Investigação do potencial de reatividade para 0 desenvolvimento de RAA dos agregados miúdos e graúdos comercializados na Região Metropolitana do Recife. In. II SIMPÓSIO SOBRE REAÇÃO ÁLCALIAGREGADO EM ESTRUTURAS DE CONCRETO, 2006, Rio de Janeiro.

ANDRIOLO, F. R. AAR dams affected in Brazil report on the current situation. In: Proceedings of the $11^{\text {th }}$ INTERNATIONAL CONFERENCE ON ALKALI AGGREGATE REACTION, 2000, Quebec, p. 1243-1252.

ANNUAL BOOK OF ASTM STANDARDS - AMERICAN SOCIETY FOR TESTING AND MATERIALS. ASTM C-150/05. Standard Specification for Portland Cement Philadelphia, 2005. v. 04.01.

ASTM C-1260/05a. Standard test method for potential alkali reactivity of aggregates (mortar-bar method). Philadelphia, 2005. section 4 (Construction), v. 04.02 (Concrete and Aggregates).

.ASTM C-1567/04. Standard Test Method for Determining the Potential Alkali-Silica Reactivity of Combinations of Cementitious Materials and Aggregate (Accelerated Mortar-Bar Method). Philadelphia, 2005. section 4 (Construction), v. 04.02 (Concrete and Aggregates).

ASTM C 151/05. Standard Test Method for Autoclave Expansion of Hydraulic Cement. Philadelphia, 2005. section 4 (Construction), v. 04.02 (Concrete and Aggregates).

.ASTM C 114/05. Standard Test Methods for Chemical Analysis of Hydraulic Cement - Water-Soluble Alkalis. Philadelphia, 2005. section 4 (Construction), v. 04.02 (Concrete and Aggregates).

ARANO, N. Comparative consideration of the mechanisms of ASR suppression due to different mineral admixtures. In: Proceedings of the $11^{\text {th }}$ INTERNATIONAL CONFERENCE ON ALKALI - AGGREGATE REACTION, 2000, Quebec, p. 553-562.

ASSOCIAÇÃO BRASILEIRA DE NORMAS TÉCNICAS. NBR 5733: Cimento Portland de alta resistência inicial. Rio de Janeiro, 1991. 
NBR 5735: Cimento Portland de alto-forno. Rio de Janeiro, 1991.

NBR 5751: Materiais pozolânicos - Determinação de atividade pozolânica Îndice de atividade pozolânica com cal. Rio de Janeiro, 1992.

NBR 5752: Materiais pozolânicos - Determinação de atividade pozolânica com cimento Portland - Índice de atividade pozolânica com cimento. Rio de Janeiro, 1992.

NBR 7214: Areia normal para ensaio de cimento. Rio de Janeiro, 1982.

NBR 7215: Cimento Portland - Determinação da resistência à compressão. Rio de Janeiro, 1996.

NBR 7389: Apreciação petrográfica de materiais naturais, para utilização como agregado em concreto. Rio de Janeiro, 1992.

NBR 11579: Cimento Portland - Determinação da finura por meio da peneira 75 micrômetros (número 200). Rio de Janeiro, 1991.

NBR 11582: Cimento Portland - Determinação da expansibilidade de Le Chatelier. Rio de Janeiro, 1991.

NBR 12653: Materiais pozolânicos. Rio de Janeiro, 1992.

NBR 12655: Concreto de cimento Portland - Preparo, controle e recebimento - Procedimento. Rio de Janeiro, 2006.

NBR 14656: Cimento Portland e matérias-primas - Análise química por espectrometria de raios X - Método de ensaio. Rio de Janeiro, 2001.

NBR NM 11: Cimento Portland - Análise química - Método optativo para determinação de óxidos principais por complexometria. Rio de Janeiro, 2004.

NBR NM 13: Cimento Portland - Análise química - Determinação de óxido de cálcio livre pelo etileno glicol. Rio de Janeiro, 2004.

NBR NM 15: Cimento Portland - Análise química - Determinação de resíduo insolúvel. Rio de Janeiro, 2004.

NBR NM 16: Cimento Portland - Análise química - Determinação de anidrido sulfúrico. Rio de Janeiro, 2004. 
NBR NM 17: Cimento Portland - Análise química - Método de arbitragem para a determinação de óxido de sódio e óxido de potássio por fotometria de chama. Rio de Janeiro, 2004.

NBR NM 18: Cimento Portland - Análise química - Determinação de perda ao fogo. Rio de Janeiro, 2004.

NBR NM 20: Cimento Portland e suas matérias-primas - Análise química Determinação de dióxido de carbono por gasometria. Rio de Janeiro, 2004.

NBR NM 22: Cimento Portland com adições de materiais pozolânicos Análise química - Método de arbitragem. Rio de Janeiro, 2004.

NBR NM 23: Cimento Portland e outros materiais em pó - Determinação de massa específica. Rio de Janeiro, 2000.

NBR NM 25: Materiais pozolânicos - Determinação do teor de álcalis disponíveis. Rio de Janeiro, 2004.

NBR NM 43: Cimento Portland - Determinação da pasta de consistência normal. Rio de Janeiro, 2002.

NBR NM 65: Cimento Portland - Determinação do tempo de pega. Rio de Janeiro, 2002.

NBR NM 76: Cimento Portland - Determinação da finura pelo método de permeabilidade ao ar (Método de Blaine). Rio de Janeiro, 1998.

NBR NM ISO 3310-1: Peneiras de ensaio - Requisitos técnicos e verificação - Parte 1: Peneiras de ensaio com tela de tecido metálico. Rio de Janeiro, 1996.

BATTAGIN, A. F.; ESPER, M. W. Contribuição ao conhecimento das propriedades do cimento Portland de alto-forno. São Paulo, ABCP, 1988. 123p. (ET-90).

BULTEEL, D. et al. Alkali-silica reaction A method to quantify the reaction degree. Cement and Concrete Research 32 (2002) p. 1199-1206.

CHATTERJI, S. The role off $\mathrm{Ca}(\mathrm{OH})_{2}$ in the breakdown of Portland cement concrete due to alkali silica reaction. Cement and Concrete Research 9 (1979) p. 185-188.

CHATTERJI, S. Some fundamental aspects of alkali-silica reaction. In: Proceedings of the $11^{\text {th }}$ INTERNATIONAL CONFERENCE ON ALKALI - AGGREGATE REACTION, 2000, Quebec, p. 21-29.

CHATTERJI, S. Chemistry of alkali-silica reaction and testing of aggregates. Cement \& Concrete Composites 27 (2005) 788-795. 
COLLINS, C.L., et al. Examination of the effects of $\mathrm{LiOH}, \mathrm{LiCl}$, and $\mathrm{LiNO} 3$ on alkalisilica reaction. Cement and Concrete Research 34 (2004) p. 1403-1415.

COLLINS, C. L., et al. Alkali-Silica Reaction:"The Cancer of Concrete" School of Civil and Environmental Engineering, Georgia Institute of Technology. Disponível em: http://www.ce.gatech.edu/ kkurtis/gwillis/learn4.htm. Acesso em 18 jan. 2007.

DAL MOLIN, D. C. C. Adições minerais para concreto estrutural. In: ISAIAS, G. C. Concreto: Ensino, Pesquisa e Realizações. São Paulo: IBRACON, 2005 p. 345-379.

DANA, H. Manual de mineralogia. Rio Janeiro: Editora da Universidade de São Paulo, 1969. v. 1 e 2.

DIAMOND, S. A review of alkali-silica reaction and expansion mechanisms 1 . Alkalies in cements and in concrete pore solutions. Cement and Concrete Research 5 (1975) p. 329-346.

DIAMOND, S. ASR: Another look at mechanisms. In: International Conference on Alkali-Aggregate Reaction (ICAAR), 8th., 1989, Kyoto. Proceedings... Kyoto: Edited by K. Okada, S. Nishibayashi \& M. Kawamura, 1989. p. 83-94.

DIAMOND, S. Unique response of $\mathrm{LiNO3}$ as an alkali sílica reaction-preventive admixture. Cement and Concrete Research 29 (1999) p. 1271-1275.

DUCHESNE, J., and BÉRUBÉ, M.A. 1994a. The effectiveness of supplementary cementing materials in suppressing expansion due to ASR: Another look at the reaction mechanisms: Part 1: Concrete expansion and portlandite depletion. Cement and Concrete Research, 24 (1994) p. 73-82.

DUCHESNE, J., and BÉRUBÉ, M.A. 1994b. The effectiveness of supplementary cementing materials in suppressing expansion due to ASR: Another look at the reaction mechanisms: Part 2: Pore solution chemistry. Cement and Concrete Research, 24 (1994) p. 221-230.

Federal Highway Administration. Protocol for Selecting Alkali-Silica Reaction (ASR)Affected Structures for Lithium Treatment. Publication nํ. FHWA-HRT-04-113 august 2004.

FENGA. X. et all. Studies on lithium salts to mitigate ASR-induced expansion in new concrete: a critical review. Cement and Concrete Research 35 (2005) p. 1789-1796.

FOURNIER, B., BÉRUBÉ. M. A. Alkali-aggregate reaction in concrete: a review of basic concepts and engineering implications. Can. J. Civ. Eng. 27 (2000) p.167-191.

GLASSER, F. P.. In: SWAMY, R. N. The Alkali-Silica Reaction in Concrete. Glasgow/London: Blackie / New York: Van Nostrand Reinhold, 1992, p. 30-53. 
GLASSER, L. S.; KATAOKA, N.. The chemistry of alkali-aggregate reaction. Cement and Concrete Research. 11 (1981) p. 1-9.

HASPARYK, N. P. Investigação dos mecanismos da reação álcali-agregado - efeito da cinza de casca de arroz e da sílica ativa. 1999. 257 p. Dissertação (Mestrado) UFG, Escola de Engenharia Civil. Goiânia, 1999.

HASPARYK, N. P. Investigação de concretos afetados pela reação álcali-agregado e caracterização avançada do gel exsudado. 2005. 326p. Tese (Doutorado em Engenharia) - Programa de Pós-Graduação em Engenharia Civil, UFRGS, Porto Alegre, 2005.

KATAYAMA, T., ST JOHN, D.A.; FUTAGAWA, T. The petrographic comparison of rocks from Japan and New Zealand - potential reactivity related to interstitial glass and silica minerals. In Proceedings of the $8^{\text {th }}$ INTERNATIONAL CONFERENCE ON ALKALI-AGGREGATE REACTION, 1989, London, p. 537-541.

KIHARA, Y. O estudo mineralógico das cinzas volantes brasileiras: origem, características e qualidade. 1983. Tese (Doutorado) - Instituto de Geociências, Universidade de São Paulo, São Paulo, 1983.

.Reação álcali-agregado: aspectos mineralógicos. In: 1ำ SIMPÓSIO NACIONAL DE AGREGADOS, 1986, São Paulo. Anais...São Paulo: Escola Politécnica da USP, 1986.

.The Influence of Carbonation of the Alkali-aggregate Reaction Mechanism. In: International Congress on the Chemistry of Cement 10 Proceedings. v.4 - 1997.

KIHARA, Y.; BUCHER, H.R. E. Microssílica: uma nova pozolana artificial. In: CONGRESSO BRASILEIRO DE CERÂMICA, Rio de Janeiro, 1986.

KIHARA, Y.; CENTURIONE, S. L. O Cimento Portland. In: ISAIAS, G. C. CONCRETO: ENSINO, PESQUISA E REALIZAÇÕES. São Paulo: IBRACON, 2005 pp.295-322.

KIHARA, Y.; SBRIGHI NETO, C.; KUPERMAN, S. C. Reação álcalis-agregado: visão atual e a situação brasileira. In: SIMPÓSIO SOBRE DURABILIDADE DO CONCRETO, 1998, São Paulo. Anais...São Paulo: IBRACON/USP, 1998.

KIHARA, Y \& SCANDIUZZI, L. Reação álcali-agregado: mecanismo, diagnose e casos brasileiros. In: 3 CONGRESSO BRASILEIRO DE CIMENTO, 1993, São Paulo. Anais...São Paulo: Associação Brasileira de Cimento Portland, 1993, v.1, p. 319-338.

KORKANC, M., TUGRUL, A. Evaluation of selected basalts from the point of alkalisilica reactivity. Cement and Concrete Research 35 (2005) pp. 505 - 512. 
KUPERMAN, S. C., et al. Tentativas para determinação do término da reação álcaliagregado na estrutura de uma tomada d'água. In: SIMPÓSIO SOBRE REATIVIDADE ÁLCALI-AGREGADO EM ESTRUTURAS DE CONCRETO, 1997, Goiânia. Anais...Goiânia: CBGB/FURNAS, 1997, p. 129-136.

KURTIS, K.; MONTEIRO P.; MEYER-ILSE, W. Examination of the effect of LiCl on ASR gel expansion. Proceedings of the $11^{\text {th }}$ INTERNATIONAL CONFERENCE ON ALKALI-AGGREGATE REACTION, 2000, Quebec, pp. 51-60.

LU, D., et al. Evaluation of laboratory test method for determining the potential alkali contribution from aggregate and the ASR safety of the Three-Gorges dam concrete, Cement and Concrete Research 36 (2006) 1157-1165.

MALVAR, L. J., et al. Alkali-Silica Reaction Mitigation: state of the art and recommendations. ACI MATERIALS JOURNAL, v. 99, n. 5, p. 480-489, 2002.

MATHER, B., How to make concrete that will not suffer deleterious alkali-silica reaction, Cement and Concrete Research 29 (1999) 1277-1280.

MEHTA, P. K., MONTEIRO, J.M. Concreto, Propriedades, Estruturas e Materiais editora Pini - 1994 - São Paulo - SP.

MOULIN, E.; BLANC, P.; SORRENTINO, P. Influence of key cement chemical parameters on the properties of metakaolin blended cements. Cement and Concrete Composites, 23 (2001) p. 463-469.

MUNHOZ F.A.C., Sustentabilidade do Cimento - Redução das emissões de $\mathrm{CO}_{2}$ no Brasil em 2003. Trabalho apresentado na Escola Politécnica da Universidade de São Paulo - EPUSP - Disciplina: Reciclagem de resíduos como materiais de construção (2004).

NEVES, S. P. A zona de cisalhamento Tauá, Ceará: sentido e estimativa do deslocamento, evolução estrutural e granitogênese associada. Revista Brasileira de Geociências 21(2) 161-173, junho de 1991.

NEVES, B. B. B. et al. O terreno alto Moxotó no Leste da Paraíba ("Maciço Caldas Brandão"). Revista Brasileira de Geociências 31 (2) 185-194, junho de 2001.

NEVILLE, A. M. Propriedades do concreto. São Paulo: Pini, 1997.

NEW ZEALAND. Cement \& Concrete Association of New Zealand. Alkali Silica Reaction Minimising the Risk of Damage to Concrete Guidance Notes and Recommended Practice(Second Edition). Technical Report 3. New Zealand, 2003. $84 p$. 
PARK, C.K.; NOHB M.H.; PARKB T.H. Rheological properties of cementitious materials containing mineral admixtures. Cement and Concrete Research 35 (2005) p. 842-849.

PECCHIO M. et al. Produtos da reação álcali-silicato em concretos de edificações da região Metropolitana do Grande Recife/PE. In. II SIMPÓSIO SOBRE REAÇÃO ÁLCALI-AGREGADO EM ESTRUTURAS DE CONCRETO, 2006, Rio de Janeiro.

PREZZI, M. et. al. Importância da química de superfície na reação álcali-agregado In: SIMPÓSIO SOBRE REATIVIDADE ÁLCALI-AGREGADO EM ESTRUTURAS DE CONCRETO, 1997, Goiânia. Anais...Goiânia: CBGB/FURNAS, 1997, p. 173-196.

PREZZI, M., MONTEIRO, P. J. M., SPOSITO, G. The Alkali-Silica Reaction - Part I: Use of the Double-Layer Theory to Explain the Behavior of Reaction-Product Gels. ACI MATERIALS JOURNAL, V. 94, № 1, January-February 1997.

PREZZI, M., MONTEIRO, J.M., SPOSITO, G. The Alkali-Silica Reaction - Part II: The Effect of Chemical Admixtures. ACI MATERIALS JOURNAL, V. 95, № 1, January-February 1998.

RAMLOCHAN, T.; THOMAS, M.; GRUBER, K.A. The effect of metakaolin on alkalisilica reaction in concrete. Cement and Concrete Research 30 (2000) p. 339-344.

SALLES, F. O desempenho de materiais pozolânicos na inibição da reação álcaliagregado. In. II SIMPÓSIO SOBRE REAÇÃO ÁLCALI-AGREGADO EM ESTRUTURAS DE CONCRETO, 2006, Rio de Janeiro.

THOMAS, M.D.A. e INNIS, F.A. Use of the accelerated mortar bar test for evaluating the efficacy of mineral admixtures for controlling expansion due to alkali-silica reaction. Cement, Concrete, and Aggregates, Vol. 21 (2), 1999, pp. 157-164.

SHEHATA, M. H; THOMAS, M.D.A. The effect of fly ash composition on the expansion of concrete due to alkali-silica reaction. Cement and Concrete Research 30 (2000) p. 1063-1072.

SIBBICK, R.G., NIXON, P. Investigation into the effects of metakaolin as a cement replacement material in ASR reactive concrete. In: Proceedings of the $11^{\text {th }}$ INTERNATIONAL CONFERENCE ON ALKALI - AGGREGATE REACTION, 2000, Quebec, p. 763-772.

SINDICATO NACIONAL DA INDÚSTRIA DO CIMENTO (SNIC). Relatório anual de 2004. Rio de Janeiro 2004. Disponível em:

http://www.snic.org.br/25set1024/abre.asp?pagina=imprensa. Acesso em 18 jan. 2007. 
STANTON, T. E. Expansion of concrete through reaction between cement and Aggregate. Proceedings of American Society of Civil Engineers, Dec 1940, p. 17811811. ASCE, V. 66 - $n^{\circ} 10$ )

TAYLOR, H. F. W. Cement chemistry. 2. ed. London: Thomas Telford, 1997.

THOMAS, M.D.A.; SHEHATA, M. H.; SHASHIPRAKASH, S.G. The use of fly ash in concrete: Classification by composition. Cement, Concrete and Aggregates. 21 (1999) p. 105-110.

VEIGA, F. N.; GONÇALVES, I.N.; HASPARYK. N. P. Microscopia eletrônica de varredura de géis provenientes de usinas hidrelétricas. In: SIMPÓSIO SOBRE REATIVIDADE ÁLCALI-AGREGADO EM ESTRUTURAS DE CONCRETO, 1997, Goiânia. Anais...Goiânia: CBGB/FURNAS, 1997, p. 69-79.

VLACH, S. R. F. A classe dos tectossilicatos: guia geral da teoria e exercício. Geologia USP: Série Didática, v. 1, n. 1, 2002. Disponível em http://www.igc.usp.br/GEOLOGIAUSP/sd1/la.php?revista=63. Acesso em 18 jan. 2007.

WANG, H., GILLOTT, J.E. Competitive nature of alkali-silica fume and alkaliaggregate (silica) reaction. Magazine of Concrete Research. 44 (1992) p. 235-239.

YAHIA, A.; TANIMURAB, M., SHIMOYAMAB, Y. Rheological properties of highly flowable mortar containing limestone filler-effect of powder content and $\mathrm{W} / \mathrm{C}$ ratio. Cement and Concrete Research 35 (2005) p. 532-539.

ZAMPIERI, V. A. Mineralogia e mecanismos de ativação e reação das pozolanas de argilas calcinadas. 1989. 191p. Dissertação (Mestrado) - Instituto de Geociências, Universidade de São Paulo, São Paulo, 1989.

.Cimento Portland aditivado com pozolanas de argilas calcinada: fabricação, hidratação e desempenho. 1993. 227p. Tese (Doutorado) - Instituto de Geociências, Universidade de São Paulo, São Paulo, 1993.

ZAMPIERI, V.A.; KIHARA, Y.; SCANDIUZZI, L. The alkali-silicate reaction in some brazilian dams. In: Proceedings of the $9^{\text {TH }}$ INTERNATIONAL CONGRESS ON THE CHEMISTRY OF CEMENT. New Delhi, Índia, 1992, Vol. V. p. 174-180. 


\section{APÊNDICE A - MÉTODOS DE ENSAIO E EQUIPAMENTOS DE CARACTERIZAÇÃO DOS MATERIAIS EMPREGADOS}

\section{$>$ Cimento CP V-ARI}

- NBR NM 23/01 Cimento Portland - Determinação da massa específica

- NBR NM 43/03 Cimento Portland - Determinação da água da pasta de consistência normal

- NBR NM 65/03 Cimento Portland - Determinação dos tempos de pega.

- NBR NM 76/98 Cimento Portland - Determinação da finura pelo método de permeabilidade ao ar (Método Blaine)

- NBR 7215/96 Cimento Portland - Determinação da resistência à compressão

- ASTM C 114/05 Standard Test methods for chemical analysis of hydraulic cement - water-soluble alkalis

- ASTM C 151/05 Standard test method for autoclave expansion of Portland cement

- NBR NM 11-2/04 Cimento Portland - Análise química - Método optativo para determinação de óxidos principais por complexometria

- NBR NM 13/04 Cimento Portland - Análise química - Determinação de óxido de cálcio livre pelo etileno glicol

- NBR NM 15/04 Cimento Portland - Análise química - Determinação de resíduo insolúvel

- NBR NM 16/04 Cimento Portland - Análise química - Determinação de anidrido sulfúrico

- NBR NM 17/04 Cimento Portland - Análise química - Método de arbitragem para a determinação de óxido de sódio e óxido de potássio por fotometria de chama

- NBR NM 18/04 Cimento Portland - Análise química - Determinação de perda ao fogo

- NBR NM 20/04 Cimento Portland e suas matérias-primas - Análise química Determinação de dióxido de carbono por gasometria 


\section{$>$ Escória de alto-forno}

- PO-GT-1027 Determinação do índice de atividade de escória pelo método rev. $03^{1} \quad$ acelerado com hidróxido de sódio

- PO-GT-3050 Análise química completa (PF, $\mathrm{SiO}_{2}, \mathrm{Al}_{2} \mathrm{O}_{3}, \mathrm{Fe}_{2} \mathrm{O}_{3}, \mathrm{CaO}, \mathrm{MgO}$, rev. 00 $\mathrm{SO}_{3}, \mathrm{Na}_{2} \mathrm{O}, \mathrm{K}_{2} \mathrm{O}, \mathrm{S}$ )

- PO-GT-5051 Determinação do grau de vitrificação e do índice de refração de rev. 00 escórias de alto-forno por microscopia de luz transmitida

\section{$>$ Cinza volante, Metacaulim e Sílica Ativa}

- NBR 5751/92 Materiais pozolânicos - Determinação de atividade pozolânica - Índice de atividade pozolânica com cal

- NBR 5752/92 Materiais pozolânicos. Determinação de atividade pozolânica com cimento Portland - Índice de atividade pozolânica com cimento

- NBR NM 25/02 Materiais pozolânicos - Determinação do teor de álcalis disponíveis

- PO-GT-3051 Análise química completa (PF, $\mathrm{SiO}_{2}, \mathrm{Al}_{2} \mathrm{O}_{3}, \mathrm{Fe}_{2} \mathrm{O}_{3}, \mathrm{CaO}$, rev. 01 $\mathrm{MgO}, \mathrm{SO}_{3}, \mathrm{Na}_{2} \mathrm{O}, \mathrm{K}_{2} \mathrm{O}$ )

- PO-GT-5042 Caracterização mineralógica por difratometria de raios X rev. 00

\footnotetext{
${ }^{1}$ PO-GT = Procedimento Operacional da Gerência de Tecnologia da Associação Brasileira de Cimento Portland para a realização de ensaios. Estes procedimentos são elaborados quando não há métodos de ensaios normalizados pela Associação Brasileira de Normas Técnicas - ABNT.
} 
$>$ Agregados

- NBR 7389/92 Apreciação petrográfica de materiais naturais, para utilização como agregado em concreto

- PO-GT-5042 Caracterização mineralógica por difratometria de raios X rev. 00

- PO-GT-3051 Análise química completa (PF, $\mathrm{SiO}_{2}, \mathrm{Al}_{2} \mathrm{O}_{3}, \mathrm{Fe}_{2} \mathrm{O}_{3}, \mathrm{CaO}, \mathrm{MgO}$, rev. 01 $\left.\mathrm{SO}_{3}, \mathrm{Na}_{2} \mathrm{O}, \mathrm{K}_{2} \mathrm{O}\right)$

\section{$>$ Barras de Argamassa - Ensaio Acelerado}

- ASTM C 1260/05a Standard test method for potential alkali reactivity of aggregates

- ASTM C 1567/04 Standard test method for determining the potential alkalisilica reactivity of combinations of cementitious materials and aggregate (Accelerated mortar-bar method)

\section{$>$ EQUIPAMENTOS}

\section{○ Difratômetro de Raios X}

Para realização das análises por difratometria de raios $\mathrm{x}$ foi utilizado um difratômetro de raios $x$, marca RIGAKU, modelo D MAX 2100, equipado com goniômetro de varredura horizontal e tubo de cobre de 2,0 kw de potência, nas seguintes condições analíticas:

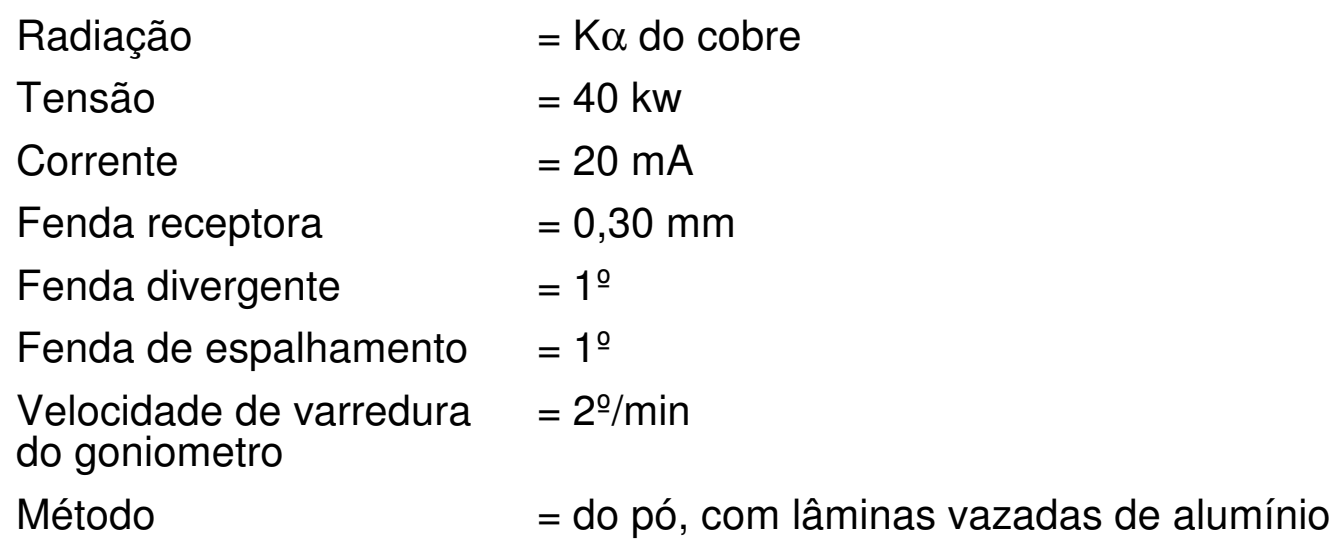




\section{- Aparelho de Análise Térmica e Termogravimétrica}

Para realização das análises térmicas nas barras de argamassa submetidas ao ensaio acelerado empregou-se um aparelho de análises termodiferencial e termogravimétrica, marca RIGAKU, modelo Thermoflex, dotado de forno de alta temperatura (até $1500^{\circ} \mathrm{C}$ ) e microprocessador (TAS 100), nas seguintes condições analíticas:

$\begin{array}{lll}\text { Taxa de aquecimento } & =10^{\circ} \mathrm{C} / \mathrm{min} \\ \text { Sensibilidade do ATD } & =200 \mu \mathrm{v} \\ \text { Sensibilidade do TG } & =20 \mathrm{mg} \\ \text { Inerte utilizado } & =\text { corindon }\left(\mathrm{Al}_{2} \mathrm{O}_{3}\right) \\ \text { Termopar } & =\text { platina-ródio } \\ \text { Cadinho } & =\text { platina-ródio } \\ \text { Capacidade do } & =0,05 \mathrm{~cm}^{3} \\ \text { cadinho } & \\ \text { Massa das amostras } & =30 \mathrm{mg} \pm 0,1 \\ \text { Velocidade do papel } & =2,5 \mathrm{~mm} / \mathrm{min}\end{array}$

\section{- Porosímetro}

Para a análise de distribuição do tamanho dos poros utilizou-se um porosímetro modelo AUTOPORE II-9215, fabricado pela Micromeritics Instruments Corporation, Estados Unidos, nas seguintes condições analíticas:

$\begin{array}{ll}\text { Tensão superficial do mercúrio } & =0,485 \mathrm{~N} / \mathrm{mm}^{2} \\ \text { Densidade mercúrio } & =13,5335 \mathrm{~g} / \mathrm{cm}^{3} \\ \text { Ângulo de contato entre o mercúrio e sólido } & =130^{\circ} \\ \text { Pressão de vácuo } & =50 \mu \mathrm{mHg} \\ \text { Pressão de mercúrio } & =1,5134 \mathrm{psia} \\ \text { Tempo de vácuo } & =5 \mathrm{~min} . \\ \text { Tempo de equilíbrio } & =15 \mathrm{~s}\end{array}$




\section{APENDICE B - CARACTERIZAÇÃO DOS MATERIAIS - RESULTADOS}

\section{Cimento Portland de Alta Resistência Inicial - CP V-ARI}

\section{$>$ Caracterização química}

A Tabela 14 apresenta os resultados das análises químicas realizadas na amostra de cimento CP V-ARI. A Tabela 15 apresenta os resultados dos teores de álcalis totais e solúveis e o equivalente alcalino em $\mathrm{Na}_{2} \mathrm{O}$ calculado.

Tabela 14 - Caracterização química do cimento CP V-ARI

\begin{tabular}{lccc}
\hline \multicolumn{1}{c}{ Ensaios } & $\begin{array}{c}\text { Métodos de } \\
\text { ensaio }\end{array}$ & $\begin{array}{c}\text { Resultados } \\
\% \text { em massa }\end{array}$ & $\begin{array}{c}\text { Limites da } \\
\text { NBR 5733/91 }\end{array}$ \\
\hline Perda ao fogo $-\mathrm{PF}$ & NBR NM 18/04 & $\mathbf{2 , 4 5}$ & $\leq 4,5 \%$ \\
\hline Dióxido de silício total $-\mathrm{SiO}_{2}$ & NBR 14656/01 & $\mathbf{1 9 , 2 1}$ & - \\
\hline Óxido de alumínio $-\mathrm{Al}_{2} \mathrm{O}_{3}$ & NBR 14656/01 & $\mathbf{4 , 9 7}$ & - \\
\hline Óxido de ferro $-\mathrm{Fe}_{2} \mathrm{O}_{3}$ & NBR 14656/01 & $\mathbf{2 , 8 9}$ & - \\
\hline Óxido de cálcio total $-\mathrm{CaO}$ & NBR 14656/01 & $\mathbf{6 4 , 5 2}$ & - \\
\hline Óxido de magnésio $-\mathrm{MgO}$ & NBR 14656/01 & $\mathbf{0 , 5 0}$ & $\leq 6,5 \%$ \\
\hline Anidrido sulfúrico $-\mathrm{SO}_{3}$ & NBR NM 16/04 & $\mathbf{2 , 9 2}$ & $\leq 4,5 \%$ \\
\hline Óxido de sódio total $-\mathrm{Na}_{2} \mathrm{O}$ & NBR NM 17/04 & $\mathbf{0 , 2 6}$ & - \\
\hline Óxido de potássio total $-\mathrm{K}_{2} \mathrm{O}$ & NBR NM 17/04 & $\mathbf{0 , 9 0}$ & - \\
\hline Anidrido carbônico $-\mathrm{CO}_{2}$ & NBR NM 20/04 & $\mathbf{1 , 2 2}$ & $\leq 3,0 \%$ \\
\hline Resíduo insolúvel $-\mathrm{RI}$ & NBR NM 15/04 & $\mathbf{0 , 8 6}$ & $\leq 1,0 \%$ \\
\hline Óxido de cálcio livre $-\mathrm{CaO}$ (livre) & NBR NM 13/04 & $\mathbf{1 , 7 1}$ & - \\
\hline
\end{tabular}


Tabela 15 - Teores de álcalis solúveis e totais do cimento CP V-ARI

\begin{tabular}{llc}
\hline \multicolumn{1}{c}{ Ensaios } & $\begin{array}{c}\text { Métodos de } \\
\text { ensaio }\end{array}$ & $\begin{array}{c}\text { Resultados } \\
\text { \% em massa }\end{array}$ \\
\hline Óxido de sódio total $-\mathrm{Na}_{2} \mathrm{O}$ & NBR NM 17/04 & $\mathbf{0 , 2 6}$ \\
\hline Óxido de potássio total $-\mathrm{K}_{2} \mathrm{O}$ & NBR NM 17/04 & $\mathbf{0 , 9 0}$ \\
\hline Óxido de sódio solúvel $-\mathrm{Na}_{2} \mathrm{O}$ & ASTM C 114/05 & $\mathbf{0 , 1 0}$ \\
\hline Óxido de potássio solúvel $-\mathrm{K}_{2} \mathrm{O}$ & ASTM C 114/05 & $\mathbf{0 , 7 0}$ \\
\hline Equivalente alcalino total em $\mathrm{Na}_{2} \mathrm{O}$ & & $\mathbf{0 , 8 5}$ \\
\hline Equivalente alcalino solúvel em $\mathrm{Na}_{2} \mathrm{O}$ & & $\mathbf{0 , 5 6}$ \\
\hline
\end{tabular}

Equivalente alcalino em $\mathrm{Na}_{2} \mathrm{O}\left[\% \mathrm{Na}_{2} \mathrm{O}+\left(0,658 \times \% \mathrm{~K}_{2} \mathrm{O}\right)\right]$

\section{Caracterização físico-mecânica}

A Tabela 16 apresenta a caracterização físico-mecânica da amostra de cimento CP V-ARI.

Tabela 16 - Caracterização físico-mecânica do cimento CP V-ARI

\begin{tabular}{|c|c|c|c|c|}
\hline \multicolumn{2}{|c|}{ Ensaios } & $\begin{array}{l}\text { Métodos de } \\
\text { ensaio }\end{array}$ & Resultados & $\begin{array}{l}\text { Limites da } \\
\text { NBR 5733/91 }\end{array}$ \\
\hline \multicolumn{2}{|c|}{ Finura - resíduo na peneira de $75 \mu \mathrm{m}(\%)$} & NBR 11579/91 & 0,2 & $\leq 6,0$ \\
\hline \multicolumn{2}{|c|}{ Massa específica $\left(\mathrm{g} / \mathrm{cm}^{3}\right)$} & NBR NM 23/01 & 3,10 & - \\
\hline \multicolumn{2}{|c|}{ Área específica - Blaine $\left(\mathrm{cm}^{2} / \mathrm{g}\right)$} & NBR NM 76/98 & $4400^{a}$ & $\geq 300 \mathrm{~m}^{2} / \mathrm{kg}$ \\
\hline \multicolumn{2}{|c|}{ Água da pasta de consistência normal (\%) } & NBR NM 43/03 & 30,5 & - \\
\hline \multicolumn{2}{|l|}{ Início de pega (h:min) } & NBR NM 65/03 & 2:05 & $\geq 1 \mathrm{~h}$ \\
\hline \multicolumn{2}{|l|}{ Fim de pega (h:min) } & NBR NM 65/03 & $3: 30$ & $\leq 10 \mathrm{~h}$ \\
\hline \multirow{2}{*}{$\begin{array}{l}\text { Expansibilidade de Le } \\
\text { Chatelier - }(\mathrm{mm})\end{array}$} & a frio & NBR 11582/91 & 1,0 & - \\
\hline & a quente & NBR 11582/91 & 0,5 & $\leq 5$ \\
\hline \multicolumn{2}{|c|}{ Expansibilidade em autoclave (\%) } & ASTM C 151/05 & 0,10 & $<0,20^{\text {b }}$ \\
\hline
\end{tabular}

Resistência à compressão (MPa) - (NBR 7215/96)

\begin{tabular}{|c|c|c|c|c|c|c|c|}
\hline \multirow{2}{*}{$\begin{array}{l}\text { Idade } \\
\text { (dias) }\end{array}$} & \multicolumn{4}{|c|}{ Corpo-de-prova $\mathrm{n}^{\circ}$} & \multirow{2}{*}{ Média } & \multirow{2}{*}{$\begin{array}{c}\text { Desvio relativo } \\
\text { máximo (\%) }\end{array}$} & \multirow{2}{*}{$\begin{array}{l}\text { Limites da } \\
\text { NBR } 5733 / 91\end{array}$} \\
\hline & 1 & 2 & 3 & 4 & & & \\
\hline 1 & 25,7 & 26,1 & 26,2 & 26,4 & 26,1 & 1,5 & $\geq 14,0$ \\
\hline 3 & 42,9 & 44,1 & 43,6 & 43,4 & 43,5 & 1,4 & $\geq 24,0$ \\
\hline 7 & 46,6 & 45,9 & 47,7 & 48,3 & 47,1 & 2,5 & $\geq 34,0$ \\
\hline 28 & 55,7 & 54,8 & 55,1 & 54,4 & 55,0 & 1,3 & - \\
\hline
\end{tabular}

a. $440 \mathrm{~m}^{2} / \mathrm{kg}$

b. Limite especificado na ASTM C 1260 


\section{Escória de Alto-Forno}

\section{$>$ Caracterização química}

A Tabela 17 apresenta os resultados das análises químicas da amostra de escória de alto-forno.

Tabela 17 - Análise química da escória de alto-forno

\begin{tabular}{|c|c|}
\hline Ensaios & $\begin{array}{c}\text { Resultados } \\
\text { (\% em massa na base seca) }\end{array}$ \\
\hline Perda ao fogo -PF & 0,00 \\
\hline Dióxido de silício - $\mathrm{SiO}_{2}$ & 35,03 \\
\hline Óxido de alumínio - $\mathrm{Al}_{2} \mathrm{O}_{3}$ & 11,07 \\
\hline Óxido de ferro $-\mathrm{Fe}_{2} \mathrm{O}_{3}$ & 1,96 \\
\hline Óxido de cálcio - CaO & 44,70 \\
\hline Óxido de magnésio - MgO & 4,84 \\
\hline Óxido de sódio - $\mathrm{Na}_{2} \mathrm{O}$ & 0,10 \\
\hline Óxido de potássio - $\mathrm{K}_{2} \mathrm{O}$ & 0,31 \\
\hline Óxido de titânio $-\mathrm{TiO}_{2}$ & 0,55 \\
\hline Óxido de manganês - MnO & 0,55 \\
\hline Sulfeto (S) & 0,36 \\
\hline Óxido de sódio disponível - $\mathrm{Na}_{2} \mathrm{O}$ & 0,001 \\
\hline Óxido de potássio disponível - $\mathrm{K}_{2} \mathrm{O}$ & 0,002 \\
\hline$\frac{\mathrm{CaO}+\mathrm{MgO}+\mathrm{Al}_{2} \mathrm{O}_{3}}{\mathrm{SiO}_{2}}>1\left(^{*}\right)$ & 1,73 \\
\hline
\end{tabular}

${ }^{*}$ *) A NBR 5735/91 - Cimento Portland de alto-forno estabelece que a composição química da escória para ser adicionada ao cimento Portland deve obedecer a esta relação. 
$>$ Caracterização física

A Tabela 18 apresenta os resultados da caracterização física da escória granulada de alto-forno.

Tabela 18 - Caracterização física da escória de alto-forno

\begin{tabular}{cccc}
\hline $\begin{array}{c}\text { Massa específica } \\
\left(\mathrm{g} / \mathrm{cm}^{3}\right)\end{array}$ & $\begin{array}{c}\text { Área específica } \\
\left(\mathrm{cm}^{2} / \mathrm{g}\right)\end{array}$ & $\begin{array}{c}\text { Finura - resíduo na } \\
\text { peneira de } 75 \mu \mathrm{m}(\%)\end{array}$ & $\begin{array}{c}\text { Finura - resíduo na } \\
\text { peneira de } 45 \mu \mathrm{m}(\%)\end{array}$ \\
\hline 2,94 & 4160 & 0,2 & 0,9 \\
\hline
\end{tabular}

\section{$>$ Caracterização mineralógica}

Com base no difratograma (Figura 47), realizado com a amostra in natura, caracterizaram-se os compostos mineralógicos correspondentes à fração cristalizada da escória (10\%). A Tabela 19 apresenta os minerais identificados.

Tabela 19 - Compostos mineralógicos cristalizados identificados na escória de alto-forno

\begin{tabular}{|c|c|c|c|c|c|}
\hline \multicolumn{3}{|c|}{ Minerais } & $\begin{array}{c}\text { Fórmula Química } \\
\text { Aproximada }\end{array}$ & $\begin{array}{l}\text { Distância Interplanar } \\
\text { Principal }(\AA)\end{array}$ & Freqüência Relativa \\
\hline \multicolumn{3}{|c|}{ Gehlenita } & ${ }_{2} \mathrm{Al}_{2} \mathrm{SiO}_{7}$ & 2,85 & + \\
\hline \multicolumn{2}{|c|}{ Merwinita } & $\mathrm{Ca}_{3} \mathrm{I}$ & $\mathrm{Mg}\left(\mathrm{SiO}_{4}\right)_{2}$ & 2,75 & + \\
\hline \multicolumn{3}{|c|}{ Quartzo } & $\mathrm{SiO}_{2}$ & 3,36 & + \\
\hline Simbologia: & & $\begin{array}{l}=\text { não detectado } \\
=\text { traços } \\
=\text { presente }\end{array}$ & $\begin{array}{l}++\quad=\text { pol } \\
+++=\text { fre } \\
++++=\text { me }\end{array}$ & $\begin{array}{l}\text { freqüente } \\
\text { ente } \\
\text { freqüente }\end{array}$ & \\
\hline NOTA: & - & $\begin{array}{l}\text { A avaliação sem } \\
\text { fundamentada na } \\
\text { da simetria e do }\end{array}$ & $\begin{array}{l}\text { iquantitativa } \\
\text { altura dos } \\
\text { grau de crista }\end{array}$ & $\begin{array}{l}\text { s fases (expressa em nú } \\
\text { os de difração, cuja inter } \\
\text { idade do constituinte }\end{array}$ & $\begin{array}{l}\text { iero de asteriscos) está } \\
\text { idade é função do teor, }\end{array}$ \\
\hline
\end{tabular}




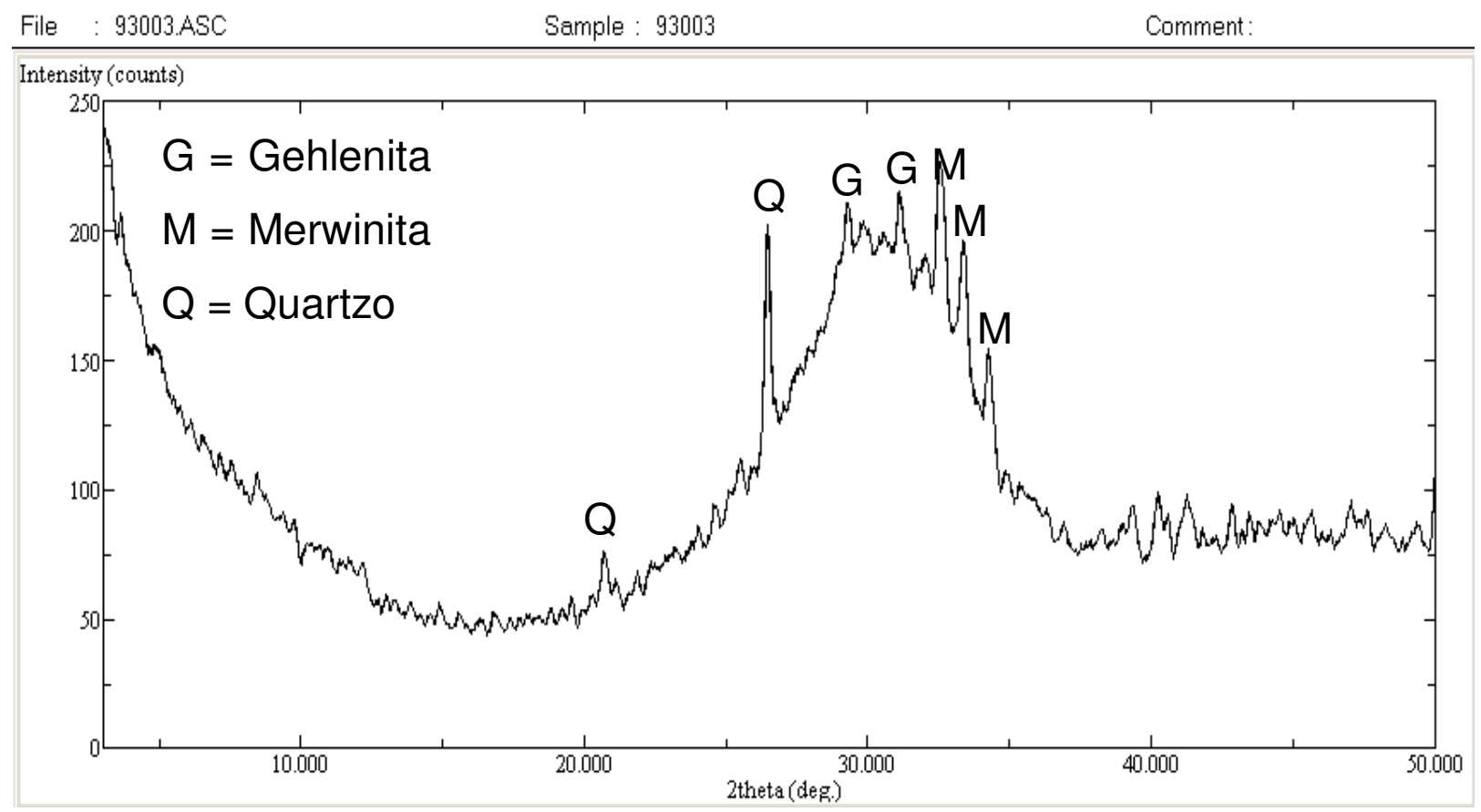

Figura 47 - Gráfico de difratometria de raios X da escória de alto-forno

\section{$>$ Grau de vitrificação e índice de refração}

A avaliação do grau de vitrificação foi feita ao microscópio óptico de luz transmitida polarizada, através da contagem dos grãos parcial e totalmente cristalizados. Como parâmetro de classificação, adotam-se os seguintes intervalos : >95\%; de 90 a 95\% e $<90 \%$ de fase vítrea.

O índice de refração é uma característica óptica intrínseca às substâncias, variando em função de seu arranjo cristalino e de sua composição química, e constituindo-se em uma ferramenta bastante útil na identificação de minerais ou qualificação de escórias, por exemplo.

As escórias que exibirem índice superior a 1,63 são consideradas básicas. Aquelas que apresentarem índice inferior a esse valor são consideradas ácidas.

A Tabela 20 apresenta o grau de vitrificação e a natureza (ácida ou básica) da escória de alto-forno. 
Tabela 20 - Grau de vitrificação e natureza da escória de alto-forno

\begin{tabular}{ccc}
\hline $\begin{array}{c}\text { Grau de } \\
\text { Vitrificação (\%) }\end{array}$ & Índice de Refração $(\mathrm{n})$ & Natureza \\
\hline 90 & $1,65<\mathrm{IR}<1,66$ & Básica \\
\hline
\end{tabular}

\section{$>$ Atividade hidráulica pelo método acelerado com soda}

Foram preparados corpos-de-prova cilíndricos de $5 \mathrm{~cm}$ de diâmetro por $10 \mathrm{~cm}$ de altura, de acordo com as recomendações da NBR 7215, exceto que o cimento foi substituído por escória, e a água, por solução aquosa de hidróxido de sódio $(200 \mathrm{~g} / \ell)$, com relação solução/escória igual a 0,50. A Tabela 21 apresenta a composição da argamassa suficiente para a elaboração de 6 corpos-de-prova.

Tabela 21 - Composição da argamassa para determinação da atividade hidráulica da escória

\begin{tabular}{ccc}
\hline Escória de alto-forno $(\mathrm{g})$ & Areia normal $^{\left({ }^{*}\right)}(\mathrm{g})$ & Solução sódica $(\mathrm{g})$ \\
\hline 624 & 1872 & 312 \\
\hline
\end{tabular}

$\left.{ }^{*}\right)$ em quatro frações, de acordo com a NBR 7214

Foram adotadas duas condições de cura: a $(23 \pm 2)^{\circ} \mathrm{C}$ durante 48 horas e a $(55 \pm 2)^{\circ} \mathrm{C}$, durante 24 horas. Os corpos-de-prova foram curados dentro das próprias fôrmas até a idade de ruptura. A cura a $23^{\circ} \mathrm{C}$ foi realizada dentro da câmara úmida com umidade relativa do ar superior a $95 \%$. A cura a $55^{\circ} \mathrm{C}$ foi realizada em estufa, tomando-se a precaução de vedar as fôrmas de modo a evitar perda de umidade. A Tabela 22 apresenta os resultados obtidos.

Tabela 22 - Atividade hidráulica da escória de alto-forno

\begin{tabular}{cccc}
\hline \multicolumn{3}{c}{$\begin{array}{c}\text { Resistência à compressão } \\
23^{\circ} \mathrm{C}(48 \mathrm{hPa}) \text { e } 55^{\circ} \mathrm{C}(24 \mathrm{~h})\left({ }^{*}\right)\end{array}$} \\
\hline $23^{\circ} \mathrm{C}$ & $(48 \mathrm{~h})$ & $55^{\circ} \mathrm{C}$ & $(24 \mathrm{~h})$ \\
\hline 11,0 & \multicolumn{2}{c}{17,9} \\
\hline
\end{tabular}

(*) Média de 6 corpos-de-prova 
No ensaio de atividade hidráulica com hidróxido de sódio em cura normal $\left(23^{\circ} \mathrm{C}\right.$ a $48 \mathrm{~h})$, os valores de resistência típicos de escórias de boa qualidade são de 7MPa a $10 \mathrm{MPa}$. Em cura acelerada, (55ํㅡ a 24h), esses valores aumentam em geral para $13 \mathrm{MPa}$ a 15MPa. Esses valores de referência são válidos para áreas específicas próximas de $3500 \mathrm{~cm}^{2} / \mathrm{g}$. A amostra analisada apresentou resistências em cura normal e acelerada acima dos valores de referência mencionados devido à maior finura. Com base nos resultados obtidos verifica-se que a amostra de escória de alto-forno é de boa qualidade e representativa das escórias normalmente adicionadas aos cimentos brasileiros.

\section{Cinza Volante}

\section{$>$ Caracterização química}

A Tabela 23 apresenta os resultados das análises químicas realizadas na amostra de cinza volante.

Tabela 23 - Composição química da cinza volante

\begin{tabular}{|c|c|c|c|}
\hline Ensaios & $\begin{array}{l}\text { Métodos de } \\
\text { ensaio }\end{array}$ & $\begin{array}{l}\text { Resultados } \\
\text { (\% em massa) }\end{array}$ & $\begin{array}{l}\text { Exigências químicas } \\
\text { NBR 12653/92 (classe C) }\end{array}$ \\
\hline Perda ao fogo - PF & NBR NM 18/04 & 1,31 & 6,0\% máx. \\
\hline Dióxido de silício total - $\mathrm{SiO}_{2}$ & NBR NM 22/04 & 66,39 & \multirow{3}{*}{$\begin{array}{c}\mathrm{SiO}_{2}+\mathrm{Al}_{2} \mathrm{O}_{3}+\mathrm{Fe}_{2} \mathrm{O}_{3} \\
70 \% \text { mím. }\end{array}$} \\
\hline Óxido de alumínio $-\mathrm{Al}_{2} \mathrm{O}_{3}$ & NBR NM 11-2/04 & 18,68 & \\
\hline Óxido de ferro $-\mathrm{Fe}_{2} \mathrm{O}_{3}$ & NBR NM 11-2/04 & 5,87 & \\
\hline Óxido de cálcio total - $\mathrm{CaO}$ & NBR NM 11-2/04 & 2,64 & - \\
\hline Óxido de magnésio - MgO & NBR NM 11-2/04 & 2,89 & - \\
\hline Anidrido sulfúrico $-\mathrm{SO}_{3}$ & NBR NM 16/04 & 0,12 & 5,0\% máx. \\
\hline Óxido de sódio total - $\mathrm{Na}_{2} \mathrm{O}$ & NBR NM 22/04 & 0,15 & - \\
\hline Óxido de potássio total $-\mathrm{K}_{2} \mathrm{O}$ & NBR NM 22/04 & 1,85 & - \\
\hline Óxido de sódio disponível - $\mathrm{Na}_{2} \mathrm{O}$ & NBR NM 25/02 & 0,00 & - \\
\hline Óxido de potássio disponível $-\mathrm{K}_{2} \mathrm{O}$ & NBR NM 25/02 & 0,004 & - \\
\hline
\end{tabular}


> Caracterização física

A Tabela 24 apresenta os resultados de caracterização física do material.

Tabela 24 - Caracterização física da cinza volante

\begin{tabular}{cccc}
\hline $\begin{array}{c}\text { Massa específica } \\
\left(\mathrm{g} / \mathrm{cm}^{3}\right)\end{array}$ & $\begin{array}{c}\text { Área específica } \\
\left(\mathrm{cm}^{2} / \mathrm{g}\right)\end{array}$ & $\begin{array}{c}\text { Material retido na } \\
\text { peneira de } 75 \mu \mathrm{m}(\%)\end{array}$ & $\begin{array}{c}\text { Material retido na } \\
\text { peneira de } 45 \mu \mathrm{m}(\%)\end{array}$ \\
\hline 2,21 & 4680 & 1,2 & $6,5^{(*)}$ \\
\hline
\end{tabular}

A NBR 12653/92 especifica que o teor máximo de material retido na peneira de $45 \mu \mathrm{m}$ é de $34 \%$

\section{Caracterização mineralógica}

Com base no difratograma (Figura 48), realizado com a amostra in natura, caracterizaram-se os compostos mineralógicos cristalizados constantes na Tabela 25.

Tabela 25 - Compostos mineralógicos cristalizados identificados na cinza volante

\begin{tabular}{|c|c|c|c|c|c|}
\hline \multicolumn{2}{|c|}{ Minerais } & \multicolumn{2}{|c|}{$\begin{array}{c}\text { Fórmula Química } \\
\text { Aproximada }\end{array}$} & $\begin{array}{l}\text { Distância Interplanar } \\
\text { Principal }(\AA)\end{array}$ & Freqüência Relativa \\
\hline \multicolumn{2}{|c|}{ Mulita } & \multicolumn{2}{|c|}{$3 \mathrm{Al}_{2} \mathrm{O}_{3} \cdot 2 \mathrm{SiO}_{2}$} & 3,39 & ++++ \\
\hline \multicolumn{3}{|c|}{ Quartzo } & $\mathrm{SiO}_{2}$ & 3,36 & +++ \\
\hline Simbologia: & & $\begin{array}{l}=\text { não detectado } \\
=\text { traços } \\
=\text { presente }\end{array}$ & $\begin{array}{l}++\quad=\text { pol } \\
+++=\text { fre } \\
++++=\text { mu }\end{array}$ & $\begin{array}{l}\text { freqüente } \\
\text { ente } \\
\text { freqüente }\end{array}$ & \\
\hline NOTA: & & $\begin{array}{l}\text { A avaliação semi } \\
\text { fundamentada na } \\
\text { da simetria e do } g\end{array}$ & $\begin{array}{l}\text { iquantitativa } \\
\text { a altura dos } \\
\text { grau de crista }\end{array}$ & $\begin{array}{l}\text { s fases (expressa em n } \\
\text { os de difração, cuja inte } \\
\text { idade do constituinte }\end{array}$ & $\begin{array}{l}\text { ero de asteriscos) está } \\
\text { idade é função do teor, }\end{array}$ \\
\hline
\end{tabular}




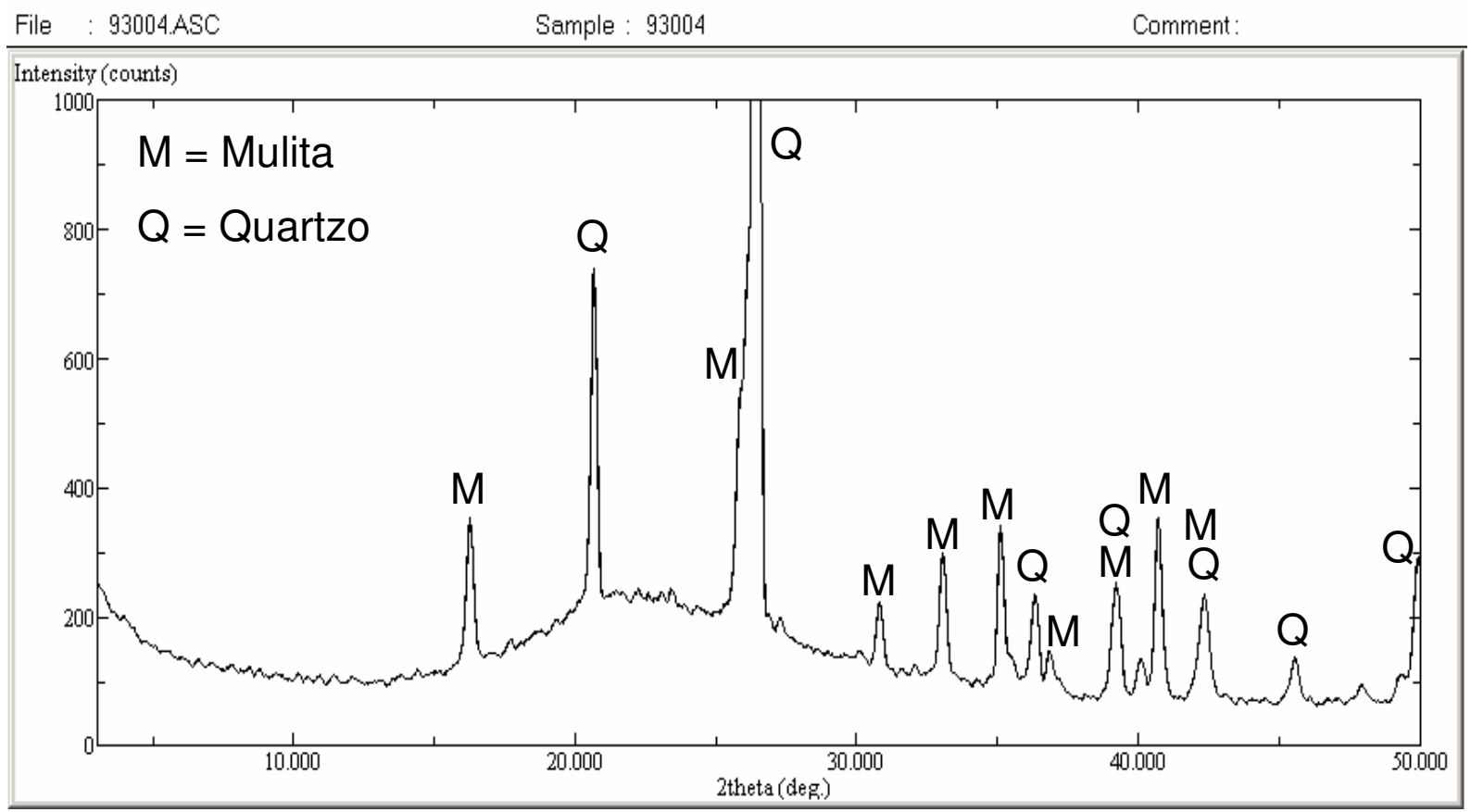

Figura 48 - Gráfico de difratometria de raios X da cinza volante

\section{Atividade pozolânica com cal}

Para a determinação do índice de atividade pozolânica com cal foram moldados três corpos-de-prova cilíndricos de $50 \mathrm{~mm}$ de diâmetro por $100 \mathrm{~mm}$ de altura, de acordo com a NBR 5751/92. A argamassa contém uma parte, em massa, de hidróxido de cálcio; nove partes, em massa, de areia normal e mais uma quantidade de material pozolânico que corresponde ao dobro do volume do hidróxido de cálcio. A Tabela 26 apresenta a composição da argamassa para a determinação do índice de atividade pozolânica com cal da amostra de cinza volante.

Tabela 26 - Composição da argamassa para o ensaio de atividade pozolânica com cal

\begin{tabular}{cccc}
\hline \multicolumn{4}{c}{ Massa dos materiais $(\mathrm{g})$} \\
\hline Areia & Cal & Cinza volante & Água $^{(1)}$ \\
\hline 936,0 & 104,0 & 205,2 & 201,0 \\
\hline
\end{tabular}

(1) Quantidade de água necessária para produzir argamassas com índice de consistência de $(225 \pm 5) \mathrm{mm}$, determinada de acordo com a NBR 7215 
O índice de atividade pozolânica com cal é a média dos valores de resistência à compressão após cura de sete dias, sendo que durante as primeiras (24 \pm 2$)$ h, os corpos-de-prova permaneceram a uma temperatura de $(23 \pm 2) \mathrm{h}$; durante as (144 \pm 2$) \mathrm{h}$ posteriores, os corpos-de-prova são mantidos a uma temperatura de $(55 \pm 2) \mathrm{C}$ até $(4 \pm 0,5) \mathrm{h}$ antes do ensaio de ruptura à compressão. Os resultados obtidos são apresentados na Tabela 27.

Tabela 27 - Índice de atividade pozolânica com cal da cinza volante

\begin{tabular}{|c|c|c|c|c|}
\hline \multicolumn{4}{|c|}{ Resultados (MPa) } & \multirow{2}{*}{$\begin{array}{l}\text { Desvio relativo } \\
\text { máximo (\%) }\end{array}$} \\
\hline CP 1 & $\mathrm{CP} 2$ & $\mathrm{CP} 3$ & Média & \\
\hline 8,7 & 9,0 & 8,7 & 8,8 & 2,3 \\
\hline
\end{tabular}

O índice de atividade pozolânica com cal especificado pela NBR 12653/92 Materiais Pozolânicos - Especificação deve ser de, no mínimo, 6,0 MPa de resistência à compressão aos 7 dias. A amostra analisada apresentou índice de atividade pozolânica com cal superior $(\mathbf{8 , 8} \mathbf{~ M P a})$ ao especificado pela norma.

\section{> Atividade pozolânica com cimento}

Para a determinação do índice de atividade pozolânica com cimento foram preparadas duas séries de três corpos-de-prova cilíndricos de $50 \mathrm{~mm}$ de diâmetro por $100 \mathrm{~mm}$ de altura, de acordo com as recomendações da NBR 5752/92, sendo uma composta por cimento Portland, água e areia normal compondo a argamassa A, e outra, substituindo-se $35 \%$ do volume do cimento pela cinza volante, argamassa B.

A Tabela 28 apresenta a composição das argamassas para a determinação do índice de atividade pozolânica da amostra de cinza volante com cimento CP V-ARI. 
Tabela 28 - Composição das argamassas para o ensaio de atividade pozolânica com cimento

\begin{tabular}{ccccc}
\hline \multirow{2}{*}{$\begin{array}{c}\text { Identificação } \\
\text { das argamassas }\end{array}$} & \multicolumn{4}{c}{ Massa dos materiais $(\mathrm{g})$} \\
\cline { 2 - 5 } & CP V-ARI & Cinza volante & Areia & Água $^{(1)}$ \\
\hline Argamassa - A & 312,0 & - & 936,0 & 171,0 \\
\hline Argamassa - B & 202,8 & 78,1 & 936,0 & 171,0 \\
\hline
\end{tabular}

(1) Quantidade de água necessária para produzir argamassas com índice de consistência de (225 \pm 5$) \mathrm{mm}$, determinada de acordo com a NBR 7215

A Tabela 29 apresenta os resultados da resistência à compressão das argamassas, do índice de atividade pozolânica com cimento e a porcentagem de água requerida.

Tabela 29 - Resistência à compressão, índice de atividade pozolânica e água requerida da cinza volante

\begin{tabular}{cccc}
\hline $\begin{array}{c}\text { Identificação das } \\
\text { argamassas }\end{array}$ & $\begin{array}{c}\text { Resistência à } \\
\text { Compressão }(\mathrm{MPa})^{(1)}\end{array}$ & $\begin{array}{c}\text { Índice de Atividade } \\
\text { Pozolânica com } \\
\text { Cimento Portland (\%) }\end{array}$ & $\begin{array}{c}\text { Água requerida } \\
(\%)^{(3)}\end{array}$ \\
\hline Argamassa - A & 46,9 & - & - \\
\hline Argamassa - B & 46,4 & $\mathbf{9 8 , 9}$ & $\mathbf{1 0 0 , 0}$ \\
\hline
\end{tabular}

(1) Média de três corpos-de-prova.

(2) O índice de atividade pozolânica com cimento Portland é dado pelo quociente entre as resistências à compressão da argamassa que contém a cinza volante (B) e argamassa de referência $(A)$, aos 28 dias, expresso em porcentagem.

(3) Água requerida é uma relação obtida entre o quociente das quantidades de água das argamassas B e A, quantidade essa necessária para produzir uma consistência de $(225 \pm 5) \mathrm{mm}$, expressa em porcentagem.

O índice de atividade pozolânica com cimento Portland especificado pela NBR 12653/92 Materiais Pozolânicos - Especificação deve ser de, no mínimo, 75\%. A porcentagem máxima de água requerida para as pozolanas classe $C$ (cinza volante) é de $110 \%$. Os ensaios realizados permitiram verificar que a amostra de cinza volante analisada atende às especificações da NBR 12653/92 quanto ao índice de atividade pozolânica com cimento e porcentagem de água requerida. 


\section{Metacaulim}

\section{$>$ Caracterização química}

A Tabela 30 apresenta os resultados da análise química realizada na amostra de metacaulim. Os ensaios foram realizados na amostra in natura.

Tabela 30 - Composição química do metacaulim

\begin{tabular}{|c|c|c|c|}
\hline Ensaios & $\begin{array}{l}\text { Métodos de } \\
\text { ensaio }\end{array}$ & $\begin{array}{c}\text { Resultados } \\
(\% \text { em massa) }\end{array}$ & $\begin{array}{c}\text { Exigências químicas } \\
\text { NBR 12653/92 } \\
\text { (classe N) }\end{array}$ \\
\hline Perda ao fogo - PF & NBR NM 18/04 & 1,99 & 10,0\% máx. \\
\hline Dióxido de silício total - $\mathrm{SiO}_{2}$ & NBR NM 22/04 & 49,92 & \multirow{3}{*}{$\begin{array}{c}\mathrm{SiO}_{2}+\mathrm{Al}_{2} \mathrm{O}_{3}+\mathrm{Fe}_{2} \mathrm{O}_{3} \\
70 \% \text { mím. }\end{array}$} \\
\hline Óxido de alumínio $-\mathrm{Al}_{2} \mathrm{O}_{3}$ & NBR NM 11-2/04 & 41,39 & \\
\hline Óxido de ferro $-\mathrm{Fe}_{2} \mathrm{O}_{3}$ & NBR NM 11-2/04 & 3,83 & \\
\hline Óxido de cálcio total - $\mathrm{CaO}$ & NBR NM 11-2/04 & 0,69 & - \\
\hline Óxido de magnésio - MgO & NBR NM 11-2/04 & 1,85 & - \\
\hline Anidrido sulfúrico $-\mathrm{SO}_{3}$ & NBR NM 16/04 & 0,09 & 4,0\% máx. \\
\hline Óxido de sódio total $-\mathrm{Na}_{2} \mathrm{O}$ & NBR NM 22/04 & 0,03 & - \\
\hline Óxido de potássio total - $\mathrm{K}_{2} \mathrm{O}$ & NBR NM 22/04 & 0,20 & - \\
\hline Óxido de sódio disponível - $\mathrm{Na}_{2} \mathrm{O}$ & NBR NM 25/02 & 0,00 & - \\
\hline Óxido de potássio disponível - $\mathrm{K}_{2} \mathrm{O}$ & NBR NM 25/02 & 0,00 & - \\
\hline $\begin{array}{l}\text { Equivalente alcalino disponível em } \mathrm{Na}_{2} \\
\left.\mathrm{Na}_{2} \mathrm{O} \%\right)\end{array}$ & $\left(0,658 \times \mathrm{K}_{2} \mathrm{O} \%+\right.$ & 0,00 & 1,5\% máx. \\
\hline
\end{tabular}

\section{> Caracterização física}

A Tabela 31 apresenta os resultados de caracterização física do material.

Tabela 31 - Caracterização física do metacaulim

\begin{tabular}{cccc}
\hline $\begin{array}{c}\text { Massa específica } \\
\left(\mathrm{g} / \mathrm{cm}^{3}\right)\end{array}$ & $\begin{array}{c}\text { Área específica } \\
\left(\mathrm{cm}^{2} / \mathrm{g}\right)_{(1)}\end{array}$ & $\begin{array}{c}\text { Material retido na } \\
\text { peneira de } 75 \mu \mathrm{m}(\%)\end{array}$ & $\begin{array}{c}\text { Material retido na } \\
\text { peneira de } 45 \mu \mathrm{m}(\%)\end{array}$ \\
\hline 2,56 & 23430 & 0,2 & 1,8 \\
\hline
\end{tabular}

(1) Valores de área específica acima de $8000 \mathrm{~cm}^{2} / \mathrm{g}$ são subestimados pelo método de permeabilidade ao ar, recomendando-se quando se requer maior precisão a utilização de outros métodos, tais como o BET (ASTM C 1069). 


\section{$>$ Caracterização mineralógica}

Com base no difratograma (Figura 49), realizado com a amostra in natura, caracterizaram-se os compostos mineralógicos cristalizados constantes na Tabela 32.

Tabela 32 - Compostos mineralógicos cristalizados identificados no metacaulim

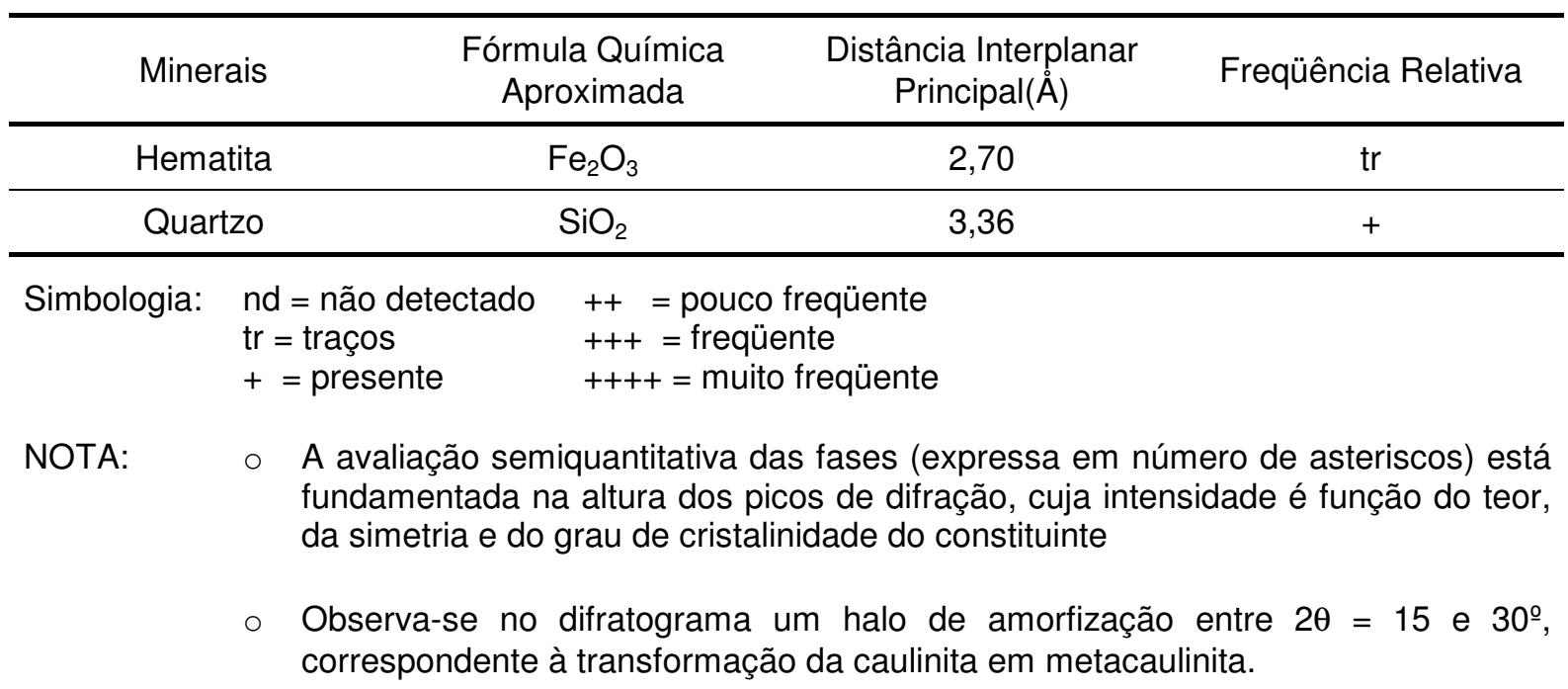

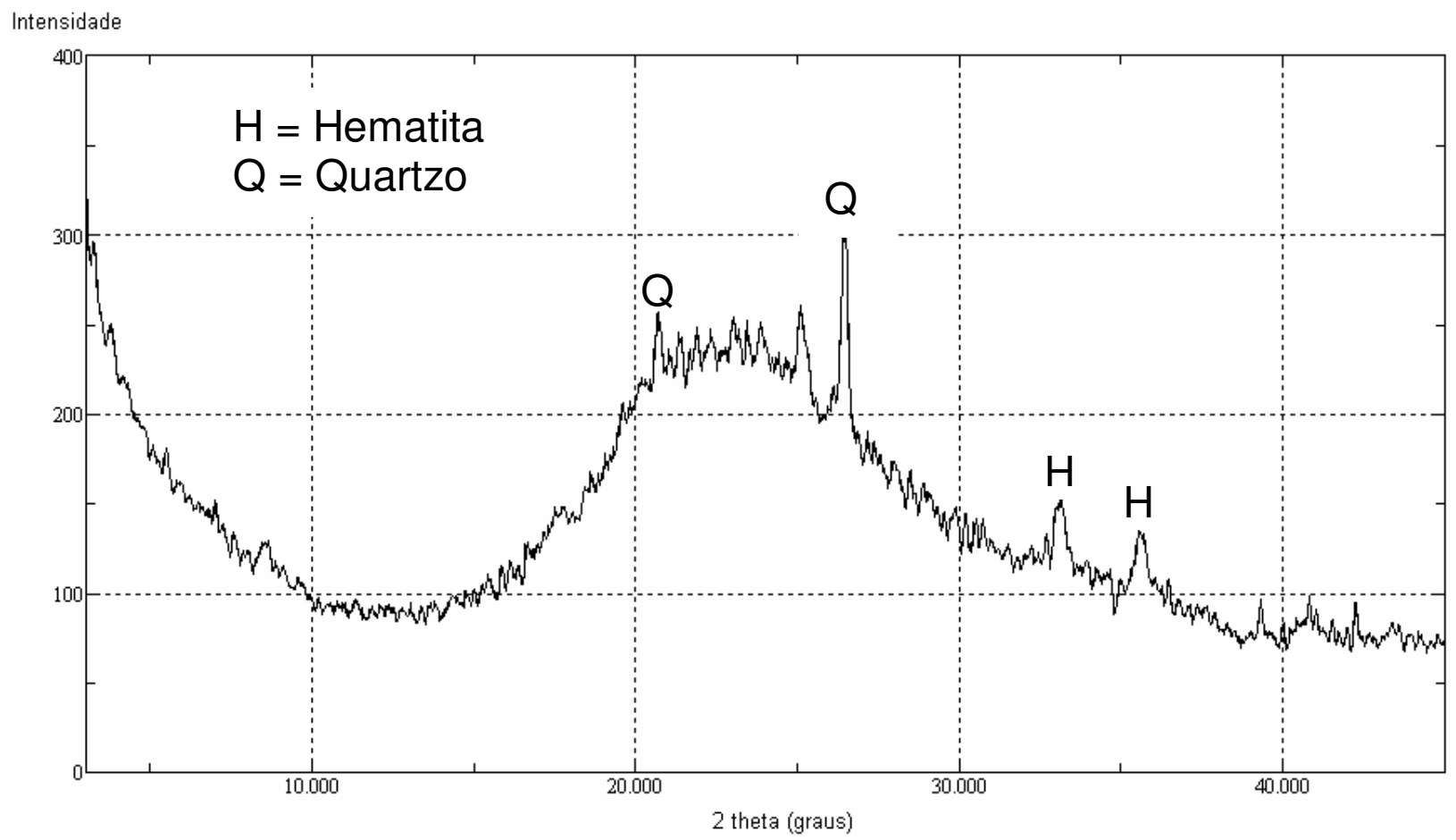

Figura 49 - Gráfico de difratometria de raios X do metacaulim 


\section{$>$ Análises Térmica e Termogravimétrica}

Com base no termograma (Figura 50), identificou-se a reação constante na Tabela 33.

Tabela 33 - Caracterização por análises termodiferencial e termogravimétrica do metacaulim

\begin{tabular}{ccc}
\hline $\begin{array}{c}\text { Temperatura do } \\
\text { pico }\left({ }^{\circ} \mathrm{C}\right)\end{array}$ & Natureza da reação & Interpretação \\
\hline 940 & exotérmica & nucleação da mulita a partir da metacaulinita \\
\hline
\end{tabular}

Com base na curva termogravimétrica, verifica-se que não há caulinita residual, indicando a eficiência do processo de calcinação do material.

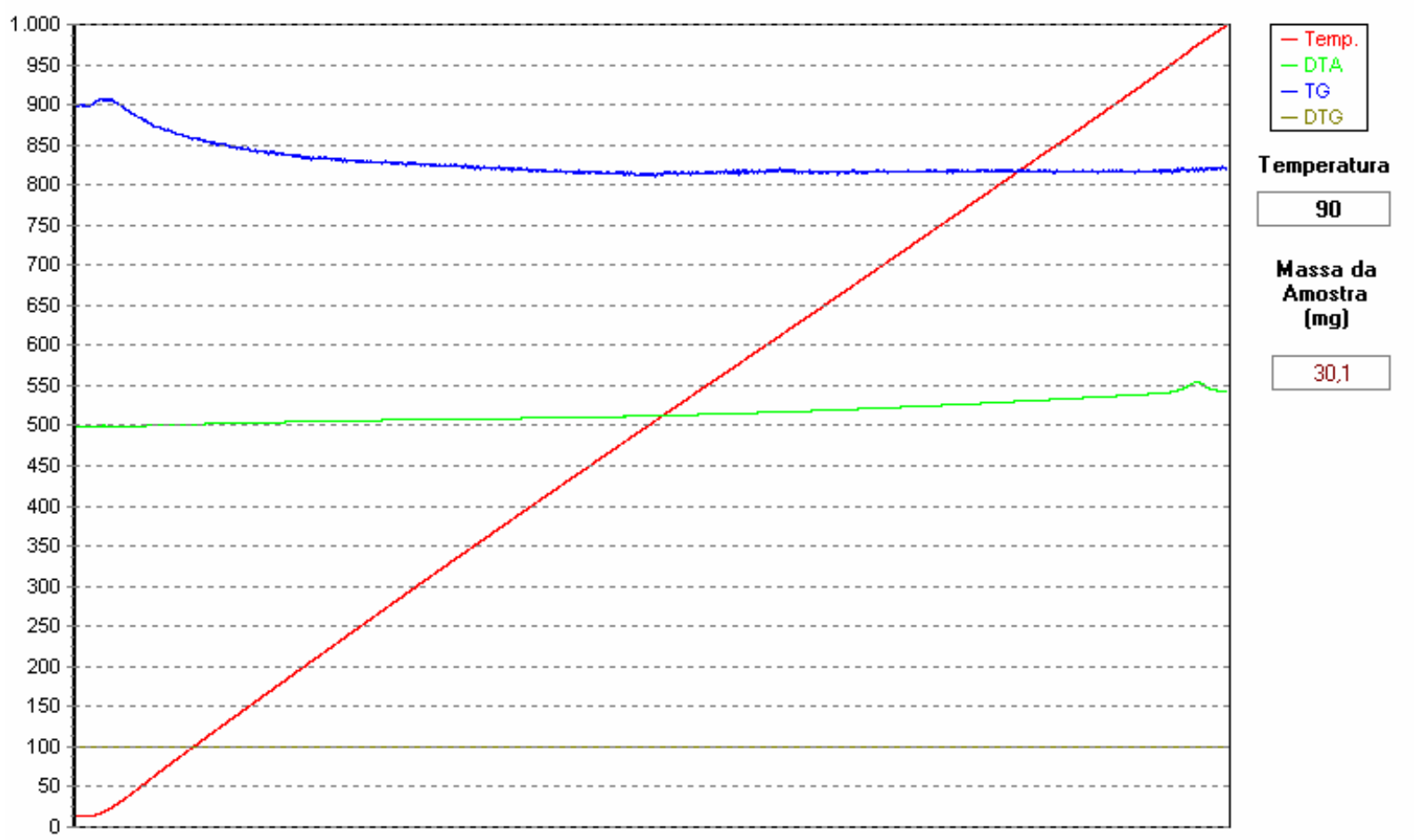

Figura 50 - Gráfico das análises térmica e termogravimétrica do metacaulim 


\section{> Atividade Pozolânica Com Cal}

A Tabela 34 apresenta a composição da argamassa para a determinação do índice de atividade pozolânica com cal da amostra de metacaulim.

Tabela 34 - Composição da argamassa para o ensaio de atividade pozolânica com cal

\begin{tabular}{cccc}
\hline \multicolumn{4}{c}{ Massa dos materiais $(\mathrm{g})$} \\
\hline Areia & Cal & Metacaulim & Água $^{(1)}$ \\
\hline 936,0 & 104,0 & 237,7 & 368,0 \\
\hline
\end{tabular}

(1) Quantidade de água necessária para produzir argamassas com índice de consistência de (225 \pm 5$) \mathrm{mm}$, determinada de acordo com a NBR 7215

Os resultados obtidos são apresentados na Tabela 35.

Tabela 35 - Índice de atividade pozolânica com cal do metacaulim

\begin{tabular}{|c|c|c|c|c|}
\hline \multicolumn{4}{|c|}{ Resultados (MPa) } & \multirow{2}{*}{$\begin{array}{l}\text { Desvio relativo } \\
\text { máximo (\%) }\end{array}$} \\
\hline CP 1 & $\mathrm{CP} 2$ & CP 3 & Média & \\
\hline 14,0 & 13,8 & 14,2 & 14,0 & 1,4 \\
\hline
\end{tabular}

O índice de atividade pozolânica com cal especificado pela NBR 12653/92 Materiais Pozolânicos - Especificação deve ser de no mínimo 6,0 MPa de resistência à compressão aos 7 dias. A amostra analisada apresentou um índice de atividade pozolânica com cal superior (14 $\mathbf{M P a}$ ) ao especificado pela norma.

\section{> Atividade Pozolânica com Cimento}

A Tabela 36 apresenta a composição das argamassas para a determinação do índice de atividade pozolânica da amostra de metacaulim com cimento CP V-ARI. 
Tabela 36 - Composição das argamassas para o ensaio de atividade pozolânica com cimento

\begin{tabular}{ccccc}
\hline \multirow{2}{*}{$\begin{array}{c}\text { Identificação } \\
\text { das argamassas }\end{array}$} & CP V-ARI & Areia & Metacaulim & Água $^{(1)}$ \\
\cline { 2 - 5 } & 312,0 & 936,0 & - & 175,0 \\
\hline Argamassa - A & 202,8 & 936,0 & 90,2 & 225,0 \\
\hline Argamassa - B & Massa dos materiais $(\mathrm{g})$ \\
\hline
\end{tabular}

(1) Quantidade de água necessária para produzir argamassas com índice de consistência de (225 \pm 5$) \mathrm{mm}$, determinada de acordo com a NBR 7215

A Tabela 37 apresenta os resultados da resistência à compressão das argamassas, do índice de atividade pozolânica com cimento e a porcentagem de água requerida.

Tabela 37 - Resistência à compressão, índice de atividade pozolânica e água requerida do metacaulim

\begin{tabular}{cccc}
\hline $\begin{array}{c}\text { Identificação das } \\
\text { argamassas }\end{array}$ & $\begin{array}{c}\text { Resistência à } \\
\text { Compressão }(\mathrm{MPa})^{(1)}\end{array}$ & $\begin{array}{c}\text { Índice de Atividade } \\
\text { Pozolânica com } \\
\text { Cimento Portland }(\%)^{(2)}\end{array}$ & $\begin{array}{c}\text { Água requerida } \\
(\%)^{(3)}\end{array}$ \\
\hline Argamassa - A & 33,9 & - & - \\
\hline Argamassa - B & 30,4 & $\mathbf{8 9 , 7}$ & $\mathbf{1 2 8 , 6}$ \\
\hline
\end{tabular}

(1) Média de três corpos-de-prova.

(2) O índice de atividade pozolânica com cimento Portland é dado pelo quociente entre as resistências à compressão da argamassa que contém o metacaulim (B) e argamassa de referência $(A)$, aos 28 dias, expresso em porcentagem.

(3) Água requerida é uma relação obtida entre o quociente das quantidades de água das argamassas B e A, quantidade essa necessária para produzir uma consistência de $(225 \pm 5) \mathrm{mm}$, expressa em porcentagem.

O índice de atividade pozolânica com cimento Portland especificado pela NBR 12653/92 Materiais Pozolânicos - Especificação deve ser de no mínimo de $75 \%$. A porcentagem máxima de água requerida para as pozolanas classe $\mathrm{N}$ (naturais e artificiais) é de $115 \%$.

Os ensaios realizados permitiram verificar que a amostra de Metacaulim analisada atende às especificações da NBR 12653/92 quanto ao índice de atividade pozolânica com cimento, mas a porcentagem de água requerida ficou acima do especificado. 


\section{Sílica Ativa}

\section{$>$ Caracterização química}

A Tabela 38 apresenta os resultados da análise química realizada na amostra de sílica ativa. Os ensaios foram realizados na amostra in natura.

Tabela 38 - Composição química da sílica ativa

\begin{tabular}{|c|c|c|c|}
\hline Ensaios & $\begin{array}{l}\text { Métodos de } \\
\text { ensaio }\end{array}$ & $\begin{array}{c}\text { Resultados } \\
\text { (\% em massa) }\end{array}$ & $\begin{array}{l}\text { Exigências químicas } \\
\text { NBR } 13956 / 97\end{array}$ \\
\hline Perda ao fogo - PF & NBR NM 18/04 & 3,15 & $\leq 6,0$ \\
\hline Dióxido de silício total - $\mathrm{SiO}_{2}$ & NBR NM 22/04 & 91,56 & $\geq 85,0$ \\
\hline Óxido de alumínio - $\mathrm{Al}_{2} \mathrm{O}_{3}$ & NBR NM 11-2/04 & 0,09 & - \\
\hline Óxido de ferro $-\mathrm{Fe}_{2} \mathrm{O}_{3}$ & NBR NM 11-2/04 & 0,30 & - \\
\hline Óxido de cálcio total - $\mathrm{CaO}$ & NBR NM 11-2/04 & 0,85 & - \\
\hline Óxido de magnésio - MgO & NBR NM 11-2/04 & 0,25 & - \\
\hline Anidrido sulfúrico $-\mathrm{SO}_{3}$ & NBR NM 16/04 & 0,26 & - \\
\hline Óxido de sódio total - $\mathrm{Na}_{2} \mathrm{O}$ & NBR NM 22/04 & 0,05 & - \\
\hline Óxido de potássio total - $\mathrm{K}_{2} \mathrm{O}$ & NBR NM 22/04 & 2,40 & - \\
\hline Óxido de sódio disponível - $\mathrm{Na}_{2} \mathrm{O}$ & NBR NM 25/02 & 0,001 & - \\
\hline Óxido de potássio disponível $-\mathrm{K}_{2} \mathrm{O}$ & NBR NM 25/02 & 0,003 & - \\
\hline Equivalente alcalino em $\mathrm{Na}_{2} \mathrm{O}(0,658$ & $\left.\mathrm{K}_{2} \mathrm{O} \%+\mathrm{Na}_{2} \mathrm{O} \%\right)$ & 1,63 & $\leq 1,5 \%$ \\
\hline
\end{tabular}

\section{$>$ Caracterização mineralógica}

Com base no difratograma (Figura 51), realizado com a amostra in natura, observase que a amostra de sílica ativa é constituída essencialmente por material amorfo, representado pelo halo de amorfização entre $2 \theta=10$ e $40^{\circ}$. 


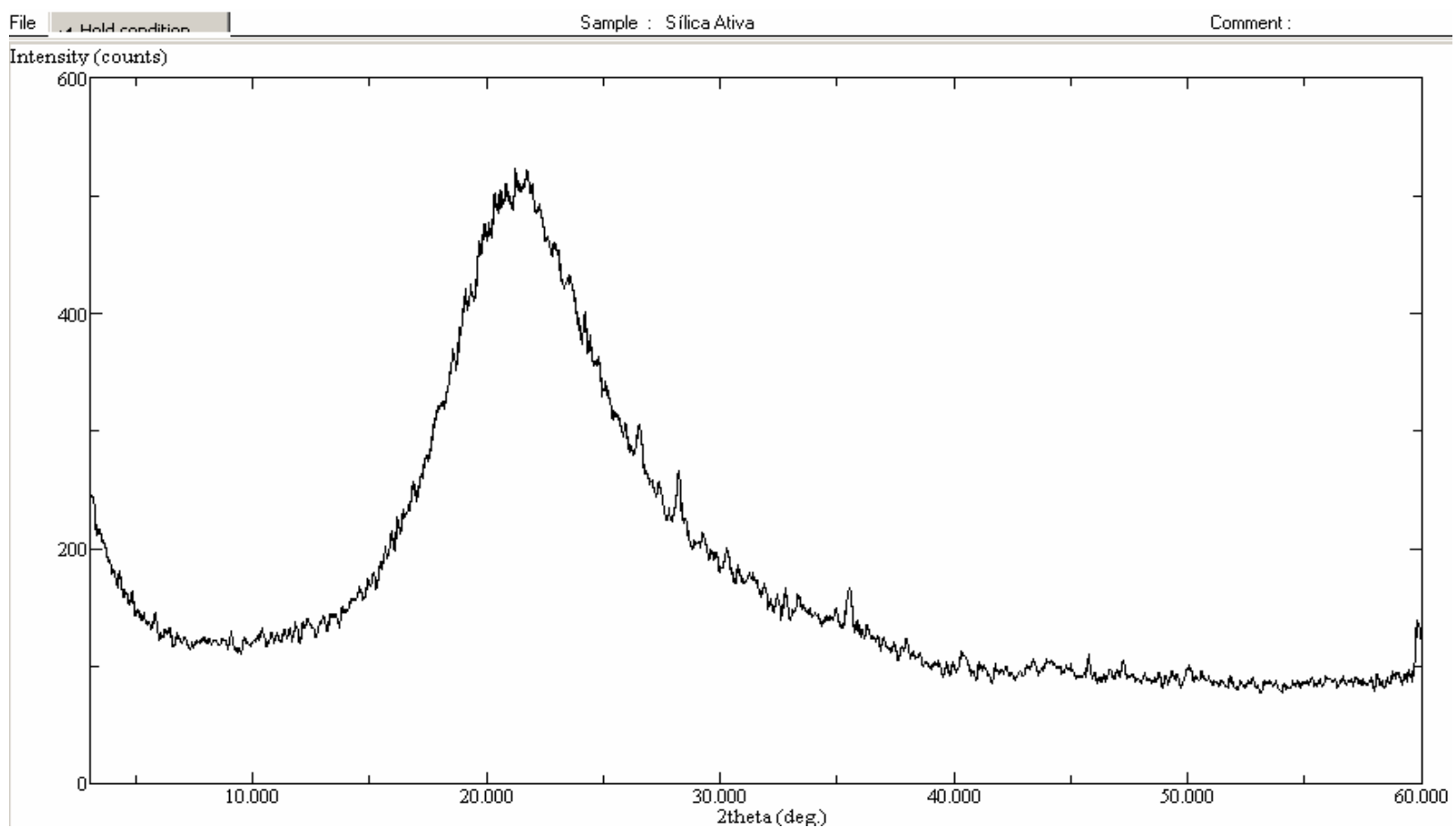

Figura 51 - Gráfico de difratometria de raios $X$ da sílica ativa

\section{Milonito granítico}

\section{$>$ Caracterização química}

A Tabela 39 apresenta os resultados das análises químicas da amostra de milonito granítico .

Tabela 39 - Análise química da amostra de milonito granítico

\begin{tabular}{lc}
\hline \multicolumn{1}{c}{ Parâmetro } & $\begin{array}{c}\text { Resultados } \\
\text { (\% em massa na base seca) }\end{array}$ \\
\hline Perda ao fogo - $\mathrm{PF}$ & $\mathbf{0 , 9 4}$ \\
\hline Dióxido de silício $-\mathrm{SiO}_{2}$ & $\mathbf{6 9 , 3 7}$ \\
\hline Óxido de alumínio $-\mathrm{Al}_{2} \mathrm{O}_{3}$ & $\mathbf{1 0 , 3 8}$ \\
\hline Óxido de ferro $-\mathrm{Fe}_{2} \mathrm{O}_{3}$ & $\mathbf{2 , 7 3}$ \\
\hline Óxido de cálcio $-\mathrm{CaO}$ & 3,45 \\
\hline Óxido de magnésio $-\mathrm{MgO}$ & $\mathbf{5 , 1 6}$ \\
\hline Anidrido sulfúrico $-\mathrm{SO}_{3}$ & $\mathbf{0 , 1 3}$ \\
\hline Óxido de sódio $-\mathrm{Na}_{2} \mathrm{O}$ & $\mathbf{3 , 9 2}$ \\
\hline Óxido de potássio $-\mathrm{K}_{2} \mathrm{O}$ & $\mathbf{3 , 6 5}$ \\
\hline
\end{tabular}




\section{$>$ Caracterização mineralógica}

Com base no difratograma (Figura 52), caracterizaram-se os compostos mineralógicos cristalizados constantes na Tabela 40.

Tabela 40 - Compostos mineralógicos cristalizados identificados na amostra de milonito granítico

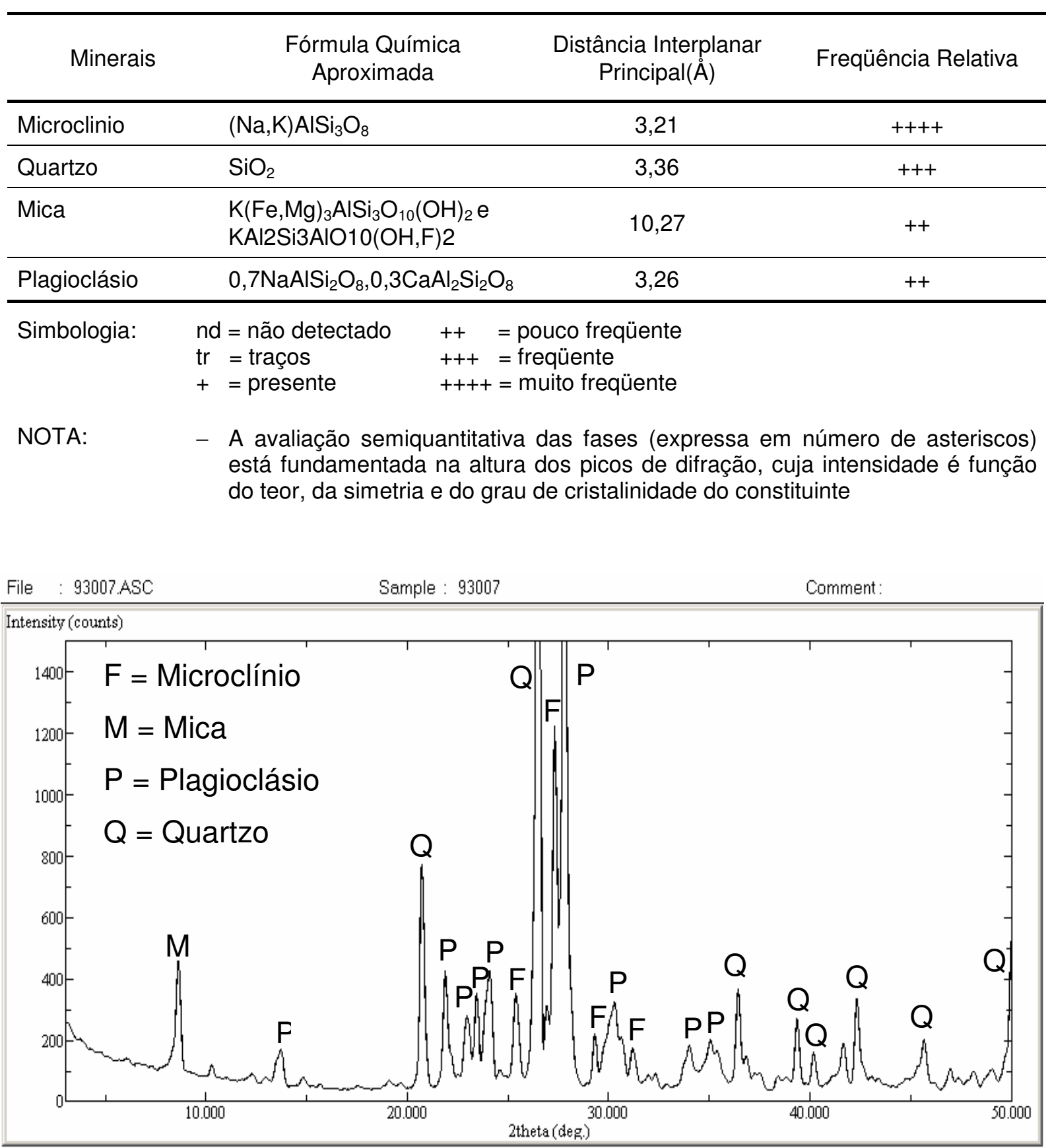

Figura 52 - Gráfico de difratometria de raios $\mathrm{X}$ do milonito granítico 


\section{$>$ Caracterização petrográfica}

A análise petrográfica foi feita primeiramente ao microscópio estereoscópico, sendo complementada por observações de lâminas delgadas ao microscópio óptico de luz transmitida. A composição mineralógica modal foi determinada através da contagem de 1000 pontos.

Classificação: Álcali-Feldspato Granito Protomilonítico (Q=26,6; A=54,5; P=18,9).

Mineralogia: Quartzo (22,0\%), Plagioclásio (15,6\%), Microclínio (45,0\%), Biotita $(7,0 \%)$, Muscovita-sericita $(6,0 \%)$, Allanita $(0,5 \%)$, Opacos $(0,9 \%)$, Apatita $(0,3 \%)$, Titanita $(0,5 \%)$, Zircão (traço), Carbonato $(0,7 \%)$, Epídoto $(1,1 \%)$ e Clorita $(0,2 \%)$, Hidróxidos de ferro $(0,2 \%)$.

Caracterização Petrográfica: Rocha foliada, com textura milonítica, com alteração leve a moderada, marcada pela presença de plagioclásios sericitizados a saussuritizados e presença localizada de hidróxidos de ferro preenchendo fraturas e interstícios.

Observam-se porfiroclastos deformados e fraturados de feldspatos, com até $3 \mathrm{~mm}$ de diâmetro, imersos em uma matriz constituída principalmente por agregados de quartzo microgranular, biotita e muscovita-sericita.

Os porfiroclastos de microclínio têm formas ocelares e, eventualmente, textura mortar. Com freqüência estão fraturados e têm geminações em grade deformadas. Sombras de pressão, preenchidas por quartzo microgranular também podem ocorrer.

Grãos menores de microclínio também são encontrados, normalmente formando agregados de grãos mais deformados e imbricados, com textura mortar. Nesses grãos mais deformados, são comuns as pertitas em chama (flame), características de regiões submetidas a tensões elevadas. 
Porfiroclastos de plagioclásio (An 30-35) exibem formas mais arredondadas e, freqüentemente têm aspecto "sujo", devido à fraca a moderada por sericitização ou saussuritização. Eventualmente, alguns porfiroclastos de plagioclásio apresentam antipertitas. São comuns cristais com geminações encurvadas e/ou extinção ondulante.

Grãos menores, a exemplo do microclínio, também ocorrem isoladamente ou formam agregados imbricados. Por vezes, nos contatos entre grãos de plagioclásio e microclínio, ocorrem mirmequitas, principalmente entre grãos de granulação mais fina.

Sustentando os feldspatos, ocorre matriz constituída por níveis e lentes de formato sigmoidal de agregados de quartzo microgranular (grãos menores que $0,15 \mathrm{~mm}$ ) extremamente deformado, por vezes recristalizado, podendo apresentar textura granoblástica poligonal. Segregação de finos níveis micáceos, compostos principalmente por biotita e muscovita-sericita, delimitam os agregados quartzosos e/ou envolvem os porfiroclastos de feldspatos. É possível que parte da muscovitasericita seja de origem metassomática, formada por afluxo de fluidos, acompanhando a deformação.

Associados aos níveis micáceos, ocorrem agregados granulares de epídoto, allanita, opacos e titanita, alinhados paralelamente à foliação milonítica. Allanita também forma cristais subdiomórficos isolados e metamitizados, com até $2,5 \mathrm{~mm}$ de comprimento maior.

Eventualmente, opacos idiomórficos, com hábito quadrado, podem ser encontrados isoladamente, nesse caso, podendo se tratar de pirita. Raramente, titanita é vista isoladamente, formando cristais subidimórficos. Pequena quantidade de clorita está presente, substituindo algumas plaquetas de biotita.

Carbonato, além de ser encontrado como produto de alteração de plagioclásio, localmente pode ocupar alguns interstícios.

Zircão e apatita ocorrem como cristais idiomórficos a subidiomórficos dispersos pela rocha ou como inclusões, principalmente em plagioclásios. 


\section{> Atividade Pozolânica com Cal}

A Tabela 41 apresenta os resultados de caracterização física do material após moagem.

Tabela 41 - Caracterização física do agregado milonito granítico após moagem

\begin{tabular}{cccc}
\hline Ensaios & $\begin{array}{c}\text { Massa específica } \\
\left(\mathrm{g} / \mathrm{cm}^{3}\right)\end{array}$ & $\begin{array}{c}\text { Área específica } \\
\left(\mathrm{cm}^{2} / \mathrm{g}\right)\end{array}$ & $\begin{array}{c}\text { Material retido na } \\
\text { peneira de 45 } 4 \mathrm{~m}(\%)\end{array}$ \\
\hline Granulometria 1 & 2,69 & 4970 & 8,6 \\
\hline Granulometria 2 & 2,69 & 10350 & 0,1 \\
\hline
\end{tabular}

A Tabela 42 apresenta a composição da argamassa para a determinação do índice de atividade pozolânica com cal da amostra de milonito granítico.

Tabela 42 - Composição da argamassa para o ensaio de atividade pozolânica com cal

\begin{tabular}{ccccc}
\hline \multirow{2}{*}{ Ensaios } & \multicolumn{5}{c}{ Massa dos materiais $(\mathrm{g})$} \\
\cline { 2 - 5 } & Areia & Cal & Milonito granítico & Água $^{(1)}$ \\
\hline Granulometria 1 & 936,0 & 104,0 & 245,4 & 202,0 \\
\hline Granulometria 2 & 936,0 & 104,0 & 245,4 & 225,0 \\
\hline
\end{tabular}

(1) Quantidade de água necessária para produzir argamassas com índice de consistência de (225 $\pm 5) \mathrm{mm}$, determinada de acordo com a NBR 7215

Os resultados obtidos são apresentados na Tabela 43.

Tabela 43 - Índice de atividade pozolânica com cal do milonito granítico

\begin{tabular}{cccccc}
\hline \multirow{2}{*}{ Ensaios } & \multicolumn{4}{c}{ Resultados (MPa) } & \multirow{2}{*}{$\begin{array}{c}\text { Desvio relativo } \\
\text { máximo (\%) }\end{array}$} \\
\cline { 2 - 5 } & CP 1 & CP 2 & CP 3 & Média & \\
\hline Granulometria 1 & 0,0 & 0,0 & 0,0 & $\mathbf{0 , 0}$ & 0,0 \\
\hline Granulometria 2 & 1,2 & 1,2 & $(1)$ & $\mathbf{1 , 2}$ & 0,0 \\
\hline
\end{tabular}

(1) Corpo-de-prova quebrou durante o capeamento com enxofre 


\section{Basalto}

\section{$>$ Caracterização química}

A Tabela 44 apresenta os resultados das análises químicas da amostra de agregado.

Tabela 44 - Análise química da amostra de basalto

\begin{tabular}{lc}
\multicolumn{1}{c}{ Ensaios } & $\begin{array}{c}\text { Resultados } \\
\text { (\% em massa na base seca) }\end{array}$ \\
\hline Perda ao fogo - PF & $\mathbf{1 , 6 0}$ \\
\hline Dióxido de silício $-\mathrm{SiO}_{2}$ & $\mathbf{5 0 , 0 3}$ \\
\hline Óxido de alumínio $-\mathrm{Al}_{2} \mathrm{O}_{3}$ & $\mathbf{1 1 , 7 4}$ \\
\hline Óxido de ferro $-\mathrm{Fe}_{2} \mathrm{O}_{3}$ & $\mathbf{1 5 , 3 9}$ \\
\hline Óxido de cálcio $-\mathrm{CaO}$ & $\mathbf{1 1 , 4 7}$ \\
\hline Óxido de magnésio $-\mathrm{MgO}$ & $\mathbf{5 , 9 9}$ \\
\hline Anidrido sulfúrico $-\mathrm{SO}_{3}$ & $\mathbf{0 , 0 2}$ \\
\hline Óxido de sódio $-\mathrm{Na}_{2} \mathrm{O}$ & $\mathbf{1 , 9 0}$ \\
\hline Óxido de potássio $-\mathrm{K}_{2} \mathrm{O}$ & $\mathbf{0 , 8 0}$ \\
\hline
\end{tabular}

Quando o teor de sílica for superior a $50 \%$ o basalto pode ser considerado potencialmente reativo e deve ser tratado como um andesito em termos de reatividade álcali-agregado (Katayama, St John \& Futagawa, 1989). 


\section{$>$ Caracterização mineralógica}

Com base no difratograma (Figura 53), caracterizaram-se os compostos mineralógicos cristalizados constantes na Tabela 45.

Tabela 45 - Compostos mineralógicos cristalizados identificados na amostra de basalto

\begin{tabular}{|c|c|c|c|}
\hline Minerais & $\begin{array}{c}\text { Fórmula Química } \\
\text { Aproximada }\end{array}$ & $\begin{array}{l}\text { Distância Interplanar } \\
\text { Principal }(\AA)\end{array}$ & Freqüência Relativa \\
\hline Piroxênio (Augita) & $\begin{array}{c}\left(\mathrm{Ca}(\mathrm{Mg}, \mathrm{Fe})\left(\mathrm{SiO}_{3}\right)_{2}\right. \\
\left.\left[(\mathrm{Al}, \mathrm{Fe})_{2} \mathrm{O}_{3}\right]\right)\end{array}$ & 3,02 & ++++ \\
\hline Plagiclásio (Andesina) & $\begin{array}{c}\left(\mathrm{Na}_{0,7-0,5}, \mathrm{Ca}_{0,3-}\right. \\
0,5) \mathrm{Al}\left(\mathrm{Al}_{0,3-0,5}, \mathrm{Si}_{0,7-}\right. \\
0,5) \mathrm{Si}_{2} \mathrm{O}_{8}\end{array}$ & 3,22 & +++ \\
\hline Magnetita & $\mathrm{Fe}_{3} \mathrm{O}_{4}$ & 2,53 & ++ \\
\hline $\begin{aligned} \mathrm{nd} & =\text { não } \\
\operatorname{tr} & =\text { traç } \\
+ & =\text { pre }\end{aligned}$ & $\begin{array}{l}++=\mathrm{po} \\
+++=\text { fre } \\
++++=\mathrm{ml}\end{array}$ & $\begin{array}{l}\text { freqüente } \\
\text { te } \\
\text { reqüente }\end{array}$ & \\
\hline
\end{tabular}

NOTA: $\quad-\quad$ A avaliação semiquantitativa das fases (expressa em número de asteriscos) está fundamentada na altura dos picos de difração, cuja intensidade é função do teor, da simetria e do grau de cristalinidade do constituinte

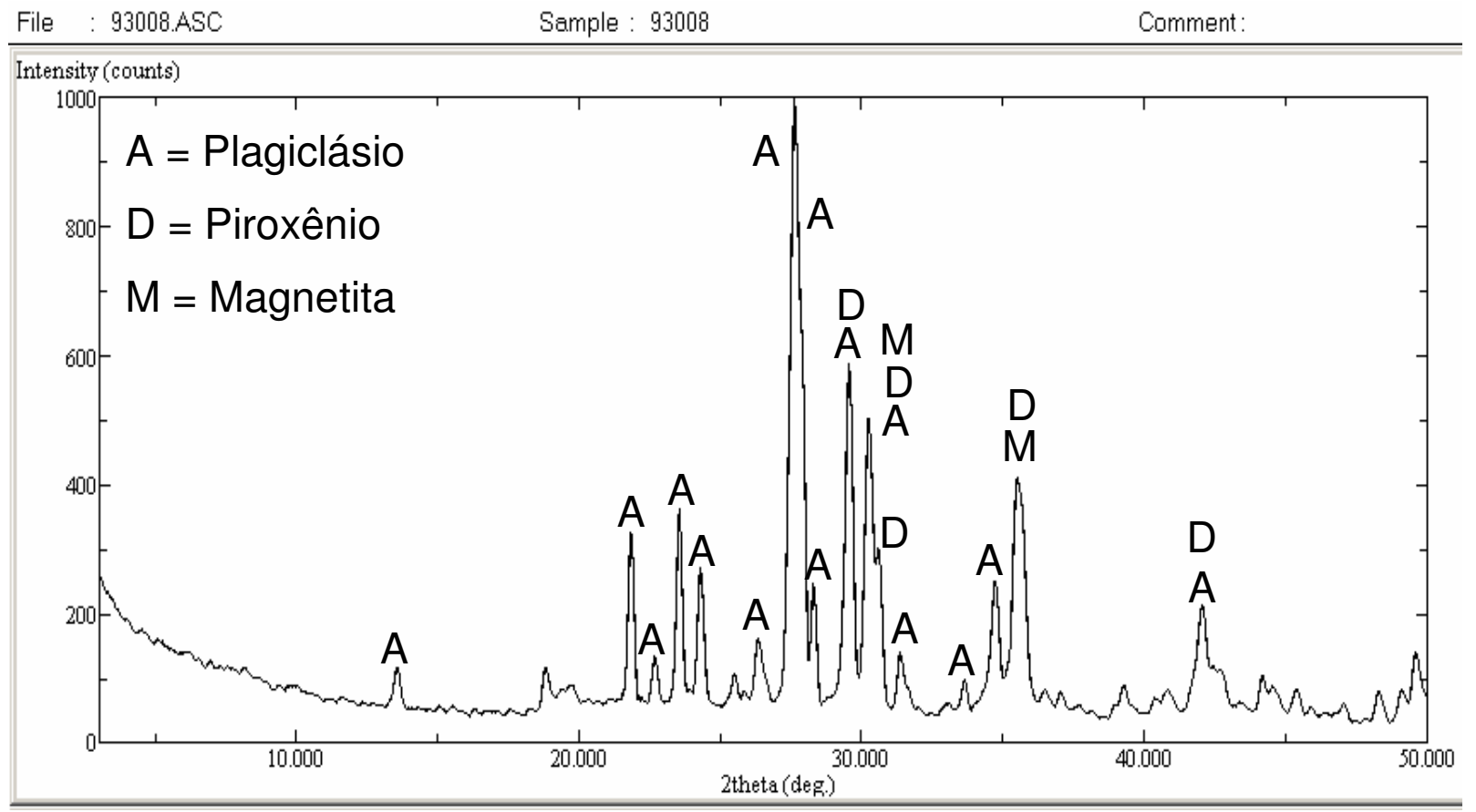

Figura 53 - Gráfico de difratometria de raios X do basalto 


\section{$>$ Caracterização petrográfica}

A análise petrográfica foi feita primeiramente ao microscópio estereoscópico, sendo complementada por observações de lâminas delgadas ao microscópio óptico de luz transmitida. A composição mineralógica modal foi determinada através da contagem de 1000 pontos.

Classificação: Basalto com pseudomorfos de olivina.

Mineralogia: Plagioclásio Andesina $\mathrm{An}_{45-50}$ (28,7\%), Augita (38,9\%), Opacos $(9,9 \%)$, Vidro escuro rico em ferro (17,9\%), Calcedônia $(0,3 \%)$, Clorofeíta $(1,7 \%)$ e Hidróxidos de ferro (1,9\%).

Caracterização Petrográfica: Rocha maciça, pouco alterada, de granulação muito fina, com textura glomeroporfirítica e matriz intersetal.

Os glomerocristais são constituídos por plagioclásios andesina $\left(\mathrm{An}_{45-50}\right)$ e augita. Os plagioclásios são idiomórficos a subidiomórficos, com hábitos prismáticos a tabulares, por vezes zonados, freqüentemente com inclusões de augitas granulares, vidro desvitrificado e com inclusões fluidas aprisionadas na forma de colares paralelamente às faces de crescimento dos cristais. As augitas desse glomerocristais são xenomórficas, raramente subidiomórficas e podem conter algumas inclusões de vidro desvitrificado. Eventualmente, alguns cristais apresentam geminação simples.

Fenocristais isolados de plagioclásio e augita também são observados, e podem atingir, no caso dos plagioclásios, até $2 \mathrm{~mm}$ de comprimento.

A matriz tem textura intersetal, caracterizada por plagioclásios ripiformes com interstícios angulares ocupados por augita granular a, eventualmente prismática, e vidro castanho escuro a preto, rico em óxidos de ferro. Em algumas porções da seção delgada, observa-se alteração fraca a moderada dos cristais de augita, caracterizada pelo recobrimento parcial dos piroxênios por película de hidróxidos de ferro e/ou clorofeíta. 
É comum a desvitrificação de vidro, observada pela presença de micrólitos de opacos arborescentes, possivelmente ilmenitas, triquitos, globulitos e, muito raramente, micrólitos de plagioclásio formando "ocos" ou textura "rabo de andorinha".

Assim com os piroxênios, o vidro poder estar substituído por clorofeíta e/ou hidróxidos de ferro.

Eventualmente, podem ser encontrados dispersos na rocha, pseudomorfos de mineral ferromagnesiano, totalmente substituídos por clorofeíta, com fraturas irregulares preenchidas por hidróxidos de ferro e, por vezes, com hábito naviforme, possivelmente se tratando de olivinas intensamente alteradas.

Localmente, calcedônia é vista preenchendo pequenas cavidades irregulares e interstícios entre plagioclásios ripiformes.

Uma vesícula irregularmente arredondada, medindo $0,2 \mathrm{~mm}$ de diâmetro, com paredes preenchidas por clorofeíta, foi encontrada na lâmina. 


\section{> Atividade Pozolânica com Cal}

A Tabela 46 apresenta os resultados de caracterização física do material após moagem.

Tabela 46 - Caracterização física do agregado basalto após moagem

\begin{tabular}{cccc}
\hline Ensaios & $\begin{array}{c}\text { Massa específica } \\
\left(\mathrm{g} / \mathrm{cm}^{3}\right)\end{array}$ & $\begin{array}{c}\text { Área específica } \\
\left(\mathrm{cm}^{2} / \mathrm{g}\right)\end{array}$ & $\begin{array}{c}\text { Material retido na } \\
\text { peneira de } 45 \mu \mathrm{m}(\%)\end{array}$ \\
\hline Granulometria 1 & 2,93 & 4210 & 9,5 \\
\hline Granulometria 2 & 2,93 & 6720 & 1,2 \\
\hline
\end{tabular}

A Tabela 47 apresenta a composição da argamassa para a determinação do índice de atividade pozolânica com cal da amostra de basalto.

Tabela 47 - Composição da argamassa para o ensaio de atividade pozolânica com cal

\begin{tabular}{ccccc}
\hline \multirow{2}{*}{ Ensaios } & \multicolumn{5}{c}{ Massa dos materiais $(\mathrm{g})$} \\
\cline { 2 - 5 } & Areia & Cal & Basalto & Água $^{(1)}$ \\
\hline Granulometria 1 & 936,0 & 104,0 & 267,3 & 202,0 \\
\hline Granulometria 2 & 936,0 & 104,0 & 267,3 & 212,0 \\
\hline
\end{tabular}

(1) Quantidade de água necessária para produzir argamassas com índice de consistência de $(225 \pm 5) \mathrm{mm}$, determinada de acordo com a NBR 7215

Os resultados obtidos são apresentados na Tabela 48.

Tabela 48 - Índice de atividade pozolânica com cal do basalto

\begin{tabular}{|c|c|c|c|c|c|}
\hline \multicolumn{5}{|c|}{ Resultados (MPa) } & \multirow{2}{*}{$\begin{array}{l}\text { Desvio relativo } \\
\text { máximo (\%) }\end{array}$} \\
\hline Ensaios & $\mathrm{CP} 1$ & $\mathrm{CP} 2$ & CP 3 & Média & \\
\hline Granulometria 1 & 2,3 & 2,3 & 2,3 & 2,3 & 0,0 \\
\hline Granulometria 2 & 4,4 & 3,9 & 3,9 & 4,1 & 7,3 \\
\hline
\end{tabular}




\section{APÊNDICE C - RESULTADOS INDIVIDUAIS DE EXPANSÃO}

\section{Milonito granítico + Cimentos com Adição de Escória de Alto-Forno}

A Tabela 49 apresenta os resultados dos ensaios realizados pela ASTM C 1567 combinando-se a amostra de milonito granítico com os cimentos com adição de escória de alto-forno. A Figura 19 ilustra os resultados obtidos.

Tabela 49 - Variação dimensional das barras de argamassa em solução alcalina Milonito granítico + Cimento com Escória

\begin{tabular}{|c|c|c|c|c|c|}
\hline \multirow{2}{*}{$\begin{array}{l}\text { Idade de Cura } \\
\text { agressiva } \\
\text { (dias) }^{(*)}\end{array}$} & \multicolumn{5}{|c|}{ Teor de escória nos cimentos experimentais } \\
\hline & $0 \%$ & $15 \%$ & $30 \%$ & $45 \%$ & $60 \%$ \\
\hline 1 & 0,01 & 0,01 & 0,01 & 0,01 & 0,01 \\
\hline 2 & 0,01 & 0,02 & 0,01 & 0,01 & 0,01 \\
\hline 3 & - & - & - & - & - \\
\hline 4 & - & - & - & - & - \\
\hline 5 & 0,07 & 0,06 & 0,05 & 0,05 & 0,03 \\
\hline 6 & 0,09 & 0,08 & 0,07 & 0,06 & 0,04 \\
\hline 7 & 0,11 & 0,10 & 0,09 & 0,08 & 0,05 \\
\hline 8 & 0,13 & 0,12 & 0,10 & 0,09 & 0,05 \\
\hline 9 & 0,15 & 0,13 & 0,12 & 0,10 & 0,06 \\
\hline 10 & - & - & - & - & - \\
\hline 11 & - & - & - & - & - \\
\hline 12 & 0,21 & 0,19 & 0,16 & 0,13 & 0,07 \\
\hline 13 & 0,23 & 0,20 & 0,18 & 0,14 & 0,08 \\
\hline 14 & 0,25 & 0,22 & 0,19 & 0,15 & 0,09 \\
\hline 15 & 0,27 & 0,24 & 0,21 & 0,16 & 0,10 \\
\hline 16 & - & - & - & - & - \\
\hline 17 & - & - & - & - & - \\
\hline 18 & - & - & - & - & - \\
\hline 19 & 0,34 & 0,29 & 0,25 & 0,20 & 0,12 \\
\hline 20 & 0,35 & 0,31 & 0,27 & 0,21 & 0,13 \\
\hline 21 & 0,36 & 0,32 & 0,28 & 0,22 & 0,13 \\
\hline 22 & 0,38 & 0,34 & 0,30 & 0,23 & 0,14 \\
\hline 23 & - & - & - & - & - \\
\hline 24 & - & - & - & - & - \\
\hline 25 & - & - & - & - & - \\
\hline 26 & 0,43 & 0,38 & 0,33 & 0,26 & 0,16 \\
\hline 27 & 0,43 & 0,39 & 0,34 & 0,27 & 0,16 \\
\hline 28 & 0,44 & 0,40 & 0,35 & 0,27 & 0,16 \\
\hline
\end{tabular}

- = leitura não realizada

( $\left.^{\star}\right)$ Para a idade do ensaio desde a moldagem acrescente 2 dias 


\section{Milonito granítico + Cimento com Adição de Cinza Volante}

A Tabela 50 apresenta os resultados dos ensaios realizados pela ASTM C 1567 combinando-se a amostra de milonito granítico com os cimentos com adição de cinza volante. A Figura 20 ilustra os resultados obtidos.

Tabela 50 - Variação dimensional das barras de argamassa Milonito granítico + Cimento com Cinza Volante

\begin{tabular}{|c|c|c|c|c|c|}
\hline \multirow{2}{*}{$\begin{array}{l}\text { Idade de Cura } \\
\text { agressiva } \\
\text { (dias) }^{(*)}\end{array}$} & \multicolumn{5}{|c|}{ Teor de cinza volante nos cimentos experimentais } \\
\hline & $0 \%$ & $10 \%$ & $15 \%$ & $25 \%$ & $35 \%$ \\
\hline 1 & 0,01 & $-0,01$ & 0,00 & 0,00 & $-0,01$ \\
\hline 2 & 0,01 & - & - & - & - \\
\hline 3 & - & - & - & - & - \\
\hline 4 & - & 0,02 & 0,01 & 0,00 & 0,00 \\
\hline 5 & 0,07 & 0,04 & 0,02 & 0,01 & 0,01 \\
\hline 6 & 0,09 & 0,05 & 0,03 & 0,01 & 0,01 \\
\hline 7 & 0,11 & 0,07 & 0,04 & 0,02 & 0,01 \\
\hline 8 & 0,13 & 0,09 & 0,05 & 0,02 & 0,01 \\
\hline 9 & 0,15 & - & - & - & - \\
\hline 10 & - & - & - & - & - \\
\hline 11 & - & 0,14 & 0,08 & 0,02 & 0,01 \\
\hline 12 & 0,21 & 0,16 & 0,09 & 0,02 & 0,01 \\
\hline 13 & 0,23 & 0,17 & 0,09 & 0,02 & 0,01 \\
\hline 14 & 0,25 & 0,18 & 0,10 & 0,03 & 0,01 \\
\hline 15 & 0,27 & - & - & - & - \\
\hline 16 & - & - & - & - & - \\
\hline 17 & - & - & - & - & - \\
\hline 18 & - & 0,24 & 0,14 & 0,04 & 0,02 \\
\hline 19 & 0,34 & 0,26 & 0,16 & 0,04 & 0,02 \\
\hline 20 & 0,35 & 0,27 & 0,17 & 0,05 & 0,02 \\
\hline 21 & 0,36 & 0,29 & 0,18 & 0,05 & 0,02 \\
\hline 22 & 0,38 & - & - & - & - \\
\hline 23 & - & - & - & - & - \\
\hline 24 & - & - & - & - & - \\
\hline 25 & - & 0,36 & 0,23 & 0,06 & 0,02 \\
\hline 26 & 0,43 & 0,37 & 0,24 & 0,06 & 0,02 \\
\hline 27 & 0,43 & 0,38 & 0,25 & 0,06 & 0,02 \\
\hline 28 & 0,44 & 0,41 & 0,27 & 0,08 & 0,03 \\
\hline
\end{tabular}

- = leitura não realizada

$\left.{ }^{*}\right)$ Para a idade do ensaio desde a moldagem acrescente 2 dias 


\section{Milonito granítico + Cimentos com Adição de Metacaulim}

A Tabela 51 apresenta os resultados dos ensaios realizados pela ASTM C 1567 combinando-se a amostra de milonito granítico com os cimentos com adição de metacaulim. A Figura 21 ilustra os resultados obtidos.

Tabela 51 - Variação dimensional das barras de argamassa em solução alcalina Milonito granítico + Cimento com Metacaulim

\begin{tabular}{|c|c|c|c|c|c|}
\hline \multirow{2}{*}{$\begin{array}{l}\text { Idade de Cura } \\
\text { agressiva } \\
\text { (dias) }^{(*)}\end{array}$} & \multicolumn{5}{|c|}{ Teor de escória nos cimentos experimentais } \\
\hline & $0 \%$ & $5 \%$ & $10 \%$ & $15 \%$ & $20 \%$ \\
\hline 1 & 0,01 & 0,00 & 0,00 & 0,00 & 0,00 \\
\hline 2 & 0,01 & - & - & - & - \\
\hline 3 & - & - & - & - & - \\
\hline 4 & - & 0,04 & 0,02 & 0,01 & 0,00 \\
\hline 5 & 0,07 & 0,05 & 0,02 & 0,01 & 0,00 \\
\hline 6 & 0,09 & 0,07 & 0,04 & 0,02 & 0,01 \\
\hline 7 & 0,11 & 0,09 & 0,05 & 0,02 & 0,01 \\
\hline 8 & 0,13 & 0,11 & 0,06 & 0,04 & 0,02 \\
\hline 9 & 0,15 & - & - & - & - \\
\hline 10 & - & - & - & - & - \\
\hline 11 & - & - & - & - & - \\
\hline 12 & 0,21 & 0,20 & 0,13 & 0,07 & 0,04 \\
\hline 13 & 0,23 & 0,21 & 0,15 & 0,08 & 0,04 \\
\hline 14 & 0,25 & 0,23 & 0,16 & 0,09 & 0,04 \\
\hline 15 & 0,27 & 0,24 & 0,18 & 0,10 & 0,05 \\
\hline 16 & - & - & - & - & - \\
\hline 17 & - & - & - & - & - \\
\hline 18 & - & - & - & - & - \\
\hline 19 & 0,34 & 0,31 & 0,24 & 0,15 & 0,08 \\
\hline 20 & 0,35 & 0,32 & 0,25 & 0,16 & 0,08 \\
\hline 21 & 0,36 & 0,33 & 0,26 & 0,18 & 0,08 \\
\hline 22 & 0,38 & 0,34 & 0,28 & 0,18 & 0,09 \\
\hline 23 & - & - & - & - & - \\
\hline 24 & - & - & - & - & - \\
\hline 25 & - & 0,37 & 0,31 & 0,22 & 0,11 \\
\hline 26 & 0,43 & 0,38 & 0,32 & 0,22 & 0,11 \\
\hline 27 & 0,43 & 0,39 & 0,34 & 0,23 & 0,12 \\
\hline 28 & 0,44 & 0,40 & 0,35 & 0,24 & 0,12 \\
\hline
\end{tabular}

- = leitura não realizada

(*) Para a idade do ensaio desde a moldagem acrescente 2 dias 
Milonito granítico + Cimentos com Adição de Sílica Ativa

A Tabela 52 apresenta os resultados dos ensaios realizados pela ASTM C 1567 combinando-se a amostra de milonito granítico com os cimentos com adição de sílica ativa. A Figura 22 ilustra os resultados obtidos.

Tabela 52 - Variação dimensional das barras de argamassa em solução alcalina Milonito granítico + Cimento com Sílica Ativa

\begin{tabular}{|c|c|c|c|c|}
\hline \multirow{2}{*}{$\begin{array}{l}\text { Idade de Cura } \\
\text { agressiva } \\
\text { (dias) }^{(*)}\end{array}$} & \multicolumn{4}{|c|}{ Teor de escória nos cimentos experimentais } \\
\hline & $0 \%$ & $5 \%$ & $10 \%$ & $15 \%$ \\
\hline 1 & 0,01 & - & - & - \\
\hline 2 & 0,01 & - & - & - \\
\hline 3 & - & - & - & - \\
\hline 4 & - & 0,05 & 0,02 & 0,02 \\
\hline 5 & 0,07 & 0,06 & 0,03 & 0,02 \\
\hline 6 & 0,09 & 0,08 & 0,03 & 0,02 \\
\hline 7 & 0,11 & 0,10 & 0,03 & 0,03 \\
\hline 8 & 0,13 & - & - & - \\
\hline 9 & 0,15 & - & - & - \\
\hline 10 & - & - & - & - \\
\hline 11 & - & 0,17 & 0,06 & 0,03 \\
\hline 12 & 0,21 & 0,19 & 0,07 & 0,04 \\
\hline 13 & 0,23 & 0,20 & 0,08 & 0,04 \\
\hline 14 & 0,25 & 0,23 & 0,09 & 0,04 \\
\hline 15 & 0,27 & - & - & - \\
\hline 16 & - & - & - & - \\
\hline 17 & - & 0,26 & 0,11 & 0,04 \\
\hline 18 & - & 0,28 & 0,12 & 0,04 \\
\hline 19 & 0,34 & 0,29 & 0,13 & 0,05 \\
\hline 20 & 0,35 & 0,31 & 0,14 & 0,05 \\
\hline 21 & 0,36 & 0,32 & 0,15 & 0,05 \\
\hline 22 & 0,38 & - & - & - \\
\hline 23 & - & - & - & - \\
\hline 24 & - & 0,36 & 0,18 & 0,07 \\
\hline 25 & - & 0,37 & 0,19 & 0,08 \\
\hline 26 & 0,43 & 0,38 & 0,20 & 0,08 \\
\hline 27 & 0,43 & 0,40 & 0,22 & 0,09 \\
\hline 28 & 0,44 & 0,41 & 0,22 & 0,09 \\
\hline
\end{tabular}

- = leitura não realizada

$\left({ }^{*}\right)$ Para a idade do ensaio desde a moldagem acrescente 2 dias 


\section{> Basalto + Cimento com Adição de Escória de Alto-Forno}

A Tabela 53 apresenta os resultados dos ensaios realizados pela ASTM C 1567 combinando-se a amostra de basalto com os cimentos com adição de escória de alto-forno. A Figura 23 ilustra os resultados obtidos.

Tabela 53 - Variação dimensional das barras de argamassa em solução alcalina Basalto + Cimento com Escória

\begin{tabular}{|c|c|c|c|c|c|}
\hline \multirow{2}{*}{$\begin{array}{l}\text { Idade de Cura } \\
\text { agressiva } \\
\text { (dias) }^{(*)}\end{array}$} & \multicolumn{5}{|c|}{ Teor de escória nos cimentos experimentais } \\
\hline & $0 \%$ & $15 \%$ & $30 \%$ & $45 \%$ & $60 \%$ \\
\hline 1 & 0,00 & - & - & - & - \\
\hline 2 & - & - & - & - & - \\
\hline 3 & - & - & - & - & - \\
\hline 4 & 0,02 & 0,02 & 0,02 & 0,01 & 0,00 \\
\hline 5 & 0,04 & 0,04 & 0,03 & 0,03 & 0,02 \\
\hline 6 & 0,07 & 0,06 & 0,04 & 0,03 & 0,02 \\
\hline 7 & 0,13 & 0,09 & 0,05 & 0,03 & 0,02 \\
\hline 8 & 0,19 & - & - & - & - \\
\hline 9 & - & - & - & - & - \\
\hline 10 & - & 0,22 & 0,10 & 0,04 & 0,02 \\
\hline 11 & 0,39 & 0,27 & 0,13 & 0,05 & 0,02 \\
\hline 12 & 0,42 & 0,31 & 0,16 & 0,06 & 0,02 \\
\hline 13 & 0,46 & 0,36 & 0,20 & 0,07 & 0,03 \\
\hline 14 & 0,49 & 0,39 & 0,22 & 0,08 & 0,03 \\
\hline 15 & - & - & - & - & - \\
\hline 16 & - & - & - & - & - \\
\hline 17 & - & 0,50 & 0,31 & 0,13 & 0,04 \\
\hline 18 & 0,62 & 0,52 & 0,33 & 0,14 & 0,04 \\
\hline 19 & 0,65 & 0,55 & 0,36 & 0,16 & 0,05 \\
\hline 20 & 0,67 & 0,57 & 0,38 & 0,18 & 0,05 \\
\hline 21 & 0,70 & 0,59 & 0,41 & 0,19 & 0,06 \\
\hline 22 & - & - & - & - & - \\
\hline 23 & - & - & - & - & - \\
\hline 24 & - & 0,65 & 0,46 & 0,23 & 0,08 \\
\hline 25 & 0,78 & 0,67 & 0,49 & 0,25 & 0,09 \\
\hline 26 & 0,80 & 0,69 & 0,50 & 0,27 & 0,10 \\
\hline 27 & 0,81 & - & - & - & - \\
\hline 28 & 0,84 & 0,71 & 0,53 & 0,29 & 0,11 \\
\hline
\end{tabular}

- = leitura não realizada

${ }^{*}$ ) Para a idade do ensaio desde a moldagem acrescente 2 dias 


\section{$>$ Basalto + Cimento com Adição de Cinza Volante}

A Tabela 54 apresenta os resultados dos ensaios realizados pela ASTM C 1567 combinando-se a amostra de basalto com os cimentos com adição de cinza volante. A Figura 24 ilustra os resultados obtidos.

Tabela 54 - Variação dimensional das barras de argamassa em solução alcalina Basalto + Cimento com Cinza Volante

\begin{tabular}{|c|c|c|c|c|c|}
\hline \multirow{2}{*}{$\begin{array}{l}\text { Idade de Cura } \\
\text { agressiva } \\
\text { (dias) }^{(*)}\end{array}$} & \multicolumn{5}{|c|}{ Teor de cinza volante nos cimentos experimentais } \\
\hline & $0 \%$ & $10 \%$ & $15 \%$ & $25 \%$ & $35 \%$ \\
\hline 1 & 0,00 & 0,01 & 0,01 & 0,01 & 0 \\
\hline 2 & - & 0,02 & 0,01 & 0,01 & 0,01 \\
\hline 3 & - & - & - & - & - \\
\hline 4 & 0,02 & - & - & - & - \\
\hline 5 & 0,04 & 0,06 & 0,03 & 0,03 & 0,02 \\
\hline 6 & 0,07 & 0,09 & 0,04 & 0,03 & 0,02 \\
\hline 7 & 0,13 & 0,13 & 0,05 & 0,03 & 0,02 \\
\hline 8 & 0,19 & 0,16 & 0,05 & 0,03 & 0,02 \\
\hline 9 & - & 0,2 & 0,07 & 0,03 & 0,03 \\
\hline 10 & - & - & - & - & - \\
\hline 11 & 0,39 & - & - & - & - \\
\hline 12 & 0,42 & 0,31 & 0,12 & 0,03 & 0,02 \\
\hline 13 & 0,46 & 0,35 & 0,14 & 0,03 & 0,02 \\
\hline 14 & 0,49 & 0,38 & 0,16 & 0,04 & 0,03 \\
\hline 15 & - & 0,41 & 0,18 & 0,04 & 0,03 \\
\hline 16 & - & 0,44 & 0,2 & 0,04 & 0,02 \\
\hline 17 & - & - & - & - & - \\
\hline 18 & 0,62 & - & - & - & - \\
\hline 19 & 0,65 & 0,52 & 0,27 & 0,04 & 0,03 \\
\hline 20 & 0,67 & 0,55 & 0,29 & 0,05 & 0,03 \\
\hline 21 & 0,70 & 0,57 & 0,31 & 0,05 & 0,03 \\
\hline 22 & - & 0,59 & 0,33 & 0,06 & 0,03 \\
\hline 23 & - & 0,61 & 0,35 & 0,06 & 0,03 \\
\hline 24 & - & - & - & - & - \\
\hline 25 & 0,78 & - & - & - & - \\
\hline 26 & 0,80 & 0,68 & 0,41 & 0,08 & 0,04 \\
\hline 27 & 0,81 & 0,70 & 0,43 & 0,09 & 0,04 \\
\hline 28 & 0,84 & 0,71 & 0,45 & 0,10 & 0,04 \\
\hline
\end{tabular}

- = leitura não realizada

${ }^{*}$ ) Para a idade do ensaio desde a moldagem acrescente 2 dias 
$>$ Basalto + Cimento com Adição de Metacaulim

A Tabela 55 apresenta os resultados dos ensaios realizados pela ASTM C 1567 combinando-se a amostra de basalto com os cimentos com adição de metacaulim. A Figura 25 ilustra os resultados obtidos.

Tabela 55 - Variação dimensional das barras de argamassa em solução alcalina Basalto + Cimento com Metacaulim

\begin{tabular}{|c|c|c|c|c|c|}
\hline \multirow{2}{*}{$\begin{array}{l}\text { Idade de Cura } \\
\text { agressiva }^{(\text {dias })^{(*)}}\end{array}$} & \multicolumn{5}{|c|}{ Teor de escória nos cimentos experimentais } \\
\hline & $0 \%$ & $5 \%$ & $10 \%$ & $15 \%$ & $20 \%$ \\
\hline 1 & 0,00 & - & - & - & - \\
\hline 2 & - & - & - & - & - \\
\hline 3 & - & 0,02 & 0,01 & 0,00 & 0,00 \\
\hline 4 & 0,02 & 0,03 & 0,01 & 0,01 & 0,00 \\
\hline 5 & 0,04 & 0,06 & 0,02 & 0,01 & 0,01 \\
\hline 6 & 0,07 & 0,10 & 0,02 & 0,02 & 0,01 \\
\hline 7 & 0,13 & 0,14 & 0,03 & 0,02 & 0,01 \\
\hline 8 & 0,19 & - & - & - & - \\
\hline 9 & - & - & - & - & - \\
\hline 10 & - & - & - & - & - \\
\hline 11 & 0,39 & 0,34 & 0,10 & 0,04 & 0,02 \\
\hline 12 & 0,42 & 0,38 & 0,11 & 0,04 & 0,02 \\
\hline 13 & 0,46 & 0,41 & 0,13 & 0,04 & 0,02 \\
\hline 14 & 0,49 & 0,45 & 0,15 & 0,05 & 0,02 \\
\hline 15 & - & - & - & - & - \\
\hline 16 & - & - & - & - & - \\
\hline 17 & - & - & - & - & - \\
\hline 18 & 0,62 & 0,56 & 0,25 & 0,10 & 0,03 \\
\hline 19 & 0,65 & 0,58 & 0,27 & 0,11 & 0,03 \\
\hline 20 & 0,67 & 0,60 & 0,29 & 0,13 & 0,04 \\
\hline 21 & 0,70 & 0,62 & 0,31 & 0,14 & 0,04 \\
\hline 22 & - & - & - & - & - \\
\hline 23 & - & - & - & - & - \\
\hline 24 & - & 0,67 & 0,37 & 0,18 & 0,05 \\
\hline 25 & 0,78 & 0,68 & 0,38 & 0,19 & 0,05 \\
\hline 26 & 0,80 & 0,70 & 0,40 & 0,21 & 0,05 \\
\hline 27 & 0,81 & 0,71 & 0,42 & 0,22 & 0,06 \\
\hline 28 & 0,84 & 0,72 & 0,44 & 0,24 & 0,06 \\
\hline
\end{tabular}

- = leitura não realizada

${ }^{*}$ ) Para a idade do ensaio desde a moldagem acrescente 2 dias 


\section{$>$ Basalto + Cimento com Adição de Sílica Ativa}

A Tabela 56 apresenta os resultados dos ensaios realizados pela ASTM C 1567 combinando-se a amostra de basalto com os cimentos com adição de sílica ativa. A Figura 26 ilustra os resultados obtidos.

Tabela 56 - Variação dimensional das barras de argamassa em solução alcalina Basalto + Cimento com Sílica Ativa

\begin{tabular}{|c|c|c|c|c|}
\hline \multirow{2}{*}{$\begin{array}{l}\text { Idade de Cura } \\
\text { agressiva } \\
\text { (dias) }^{(*)}\end{array}$} & \multicolumn{4}{|c|}{ Teor de escória nos cimentos experimentais } \\
\hline & $0 \%$ & $5 \%$ & $10 \%$ & $15 \%$ \\
\hline 1 & 0,00 & - & - & - \\
\hline 2 & - & - & - & - \\
\hline 3 & - & - & - & - \\
\hline 4 & 0,02 & 0,03 & 0,02 & 0,01 \\
\hline 5 & 0,04 & 0,04 & 0,02 & 0,02 \\
\hline 6 & 0,07 & 0,05 & 0,02 & 0,02 \\
\hline 7 & 0,13 & 0,09 & 0,03 & 0,02 \\
\hline 8 & 0,19 & - & - & - \\
\hline 9 & - & - & - & - \\
\hline 10 & - & - & - & - \\
\hline 11 & 0,39 & 0,26 & 0,04 & 0,03 \\
\hline 12 & 0,42 & 0,30 & 0,04 & 0,03 \\
\hline 13 & 0,46 & 0,34 & 0,05 & 0,03 \\
\hline 14 & 0,49 & 0,38 & 0,07 & 0,04 \\
\hline 15 & - & - & - & - \\
\hline 16 & - & - & - & - \\
\hline 17 & - & 0,48 & 0,10 & 0,04 \\
\hline 18 & 0,62 & 0,52 & 0,12 & 0,04 \\
\hline 19 & 0,65 & 0,54 & 0,14 & 0,04 \\
\hline 20 & 0,67 & 0,57 & 0,16 & 0,05 \\
\hline 21 & 0,70 & 0,59 & 0,17 & 0,05 \\
\hline 22 & - & - & - & - \\
\hline 23 & - & - & - & - \\
\hline 24 & - & 0,67 & 0,23 & 0,07 \\
\hline 25 & 0,78 & 0,70 & 0,24 & 0,08 \\
\hline 26 & 0,80 & 0,72 & 0,26 & 0,09 \\
\hline 27 & 0,81 & 0,74 & 0,28 & 0,10 \\
\hline 28 & 0,84 & 0,77 & 0,30 & 0,11 \\
\hline
\end{tabular}

- = leitura não realizada

${ }^{*}$ ) Para a idade do ensaio desde a moldagem acrescente 2 dias 


\section{APÊNDICE D - CARACTERIZAÇÃO DAS BARRAS DE ARGAMASSA}

\section{Avaliação Mecânica das Barras de Argamassa}

Após a realização dos ensaios acelerados, determinaram-se as resistências à tração na flexão e à compressão das barras de argamassa confeccionadas com os agregados milonito granítico e basalto com todos os cimentos analisados. A Tabela 57 apresenta os resultados obtidos.

Tabela 57 - Resistências mecânicas das barras de argamassa

\begin{tabular}{|c|c|c|c|c|c|c|}
\hline \multirow{3}{*}{ 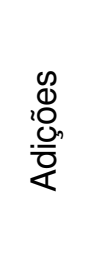 } & \multirow{3}{*}{$\begin{array}{l}\text { Tipos de } \\
\text { Cimento }\end{array}$} & \multirow{3}{*}{$\begin{array}{l}\text { Teor de adição } \\
\text { (\% em massa) }\end{array}$} & \multicolumn{4}{|c|}{ Resistências mecânicas (MPa) } \\
\hline & & & \multicolumn{2}{|c|}{$\begin{array}{l}\text { Resistência à tração } \\
\text { na flexão }\end{array}$} & \multicolumn{2}{|c|}{$\begin{array}{l}\text { Resistência à } \\
\text { compressão }{ }^{(* *)}\end{array}$} \\
\hline & & & $\begin{array}{l}\text { Milonito } \\
\text { granítico }\end{array}$ & Basalto & $\begin{array}{l}\text { Milonito } \\
\text { granítico }\end{array}$ & Basalto \\
\hline ' & CP V-ARI & 0 & 7,0 & 6,1 & 47,7 & 67,7 \\
\hline \multirow{4}{*}{ 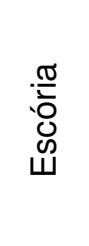 } & CP II-E & 15 & 5,3 & 7,4 & 51,7 & 74,6 \\
\hline & CP II-E & 30 & 5,3 & 8,5 & 52,6 & 77,4 \\
\hline & CP III & 45 & 7,2 & 8,5 & 62,7 & 80,6 \\
\hline & CP III & 60 & 8,4 & 10,1 & 62,9 & 82,6 \\
\hline \multirow{4}{*}{ 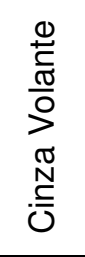 } & CP II-Z & 10 & 4,7 & 5,0 & 50,7 & 69,5 \\
\hline & CP II-Z & 15 & 6,9 & 7,0 & 55,3 & 72,2 \\
\hline & CP IV & 25 & 9,5 & 9,1 & 59,4 & 74,6 \\
\hline & CP IV & 35 & 12,5 & 11,4 & 59,9 & 70,3 \\
\hline \multirow{4}{*}{ 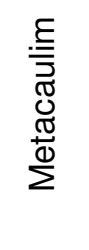 } & - & 5 & 7,0 & 6,5 & 49,2 & 64,1 \\
\hline & - & 10 & 4,4 & 5,9 & 45,6 & 59,1 \\
\hline & - & 15 & 5,9 & 7,2 & 55,0 & 61,9 \\
\hline & - & 20 & 8,2 & 8,9 & 59,8 & 64,8 \\
\hline \multirow{3}{*}{ 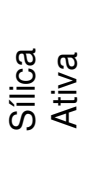 } & - & 5 & 7,4 & 5,1 & 48,5 & 61,4 \\
\hline & - & 10 & 8,1 & 6,1 & 51,9 & 58,2 \\
\hline & - & 15 & 7,6 & 7,3 & 58,8 & 60,1 \\
\hline
\end{tabular}

(*) Resultados referentes à média de duas determinações

$\left.{ }^{* *}\right)$ Resultados referentes à média de três determinações 
Para determinar a resistência à tração na flexão, as barras de argamassa foram apoiadas num dispositivo pré-ajustado com vão livre de $(100 \pm 0,5) \mathrm{mm}$. Aplicou-se uma carga no centro do vão sobre as faces laterais de moldagem da barra de argamassa de $50 \pm 10 \mathrm{~N} / \mathrm{s}$ até a ruptura da argamassa.

A resistência à tração na flexão das barras de argamassa foi calculada pela seguinte expressão:

$$
R_{F}=\frac{1,5 \cdot F_{F} \cdot L}{b^{3}}
$$

em que:

$\mathrm{R}_{\mathrm{F}}=$ resistência à traça na flexão $(\mathrm{MPa})$

$\mathrm{F}_{\mathrm{F}}=$ carga de ruptura aplicada verticalmente no centro do corpo-de-prova $(\mathrm{N})$

$\mathrm{L}=$ distância entre os suportes $(\mathrm{mm})$

$\mathrm{b}=$ lado da seção quadrada do prisma $(\mathrm{mm})$

Utilizando os semiprismas das barras de argamassa rompidos no ensaio à flexão, realizou-se o ensaio de compressão com velocidade de $2400 \pm 200 \mathrm{~N} / \mathrm{s}$ até a ruptura sobre as faces laterais de moldagem.

A resistência à compressão das barras de argamassa foi calculada pela seguinte expressão:

$$
R_{C}=\frac{F_{C}}{A}
$$

em que:

$\mathrm{R}_{\mathrm{C}}=$ resistência à compressão (MPa)

$\mathrm{F}_{\mathrm{C}}=$ carga de ruptura $(\mathrm{N})$

$A=$ Área da seção da barras de argamassa $\left(625 m^{2}\right)$ 


\section{> Análise Termodiferencial e Termogravimétrica das Barras de Argamassa com Agregado Milonito Granítico}

Para a realização das análises térmicas, fragmentos representativos da barra de argamassa $\mathrm{n}^{0} 1$ de cada combinação cimento:agregado foram moídos em moinho de disco até não deixar resíduo na peneira de 170mesh $(90 \mu \mathrm{m})$. Após a moagem, o material foi acondicionado em vidro para evitar a carbonatação.

Com base nos termogramas, identificaram-se as reações constantes na Tabela 58.

Tabela 58 - Análise termodiferencial - identificação das reações

\begin{tabular}{ccc}
\hline $\begin{array}{c}\text { Temperatura } \\
\text { do pico }\left({ }^{\circ} \mathrm{C}\right)\end{array}$ & $\begin{array}{c}\text { Natureza da } \\
\text { reação }\end{array}$ & Interpretação \\
\hline 80 & endotérmica & perda de $\mathrm{H}_{2} \mathrm{O}$ livre \\
\hline 440 & endotérmica & desidroxilação da portlandita $\left(\mathrm{Ca}(\mathrm{OH})_{2}\right)$ \\
\hline 610 & endotérmica & descarbonatação da calcita $\left(\mathrm{CaCO}_{3}\right)$ \\
\hline
\end{tabular}

Com base nas curvas termogravimétricas, definiram-se faixas de temperatura com o intuito de calcular as perdas de massa conforme descrito na Tabela 59. Calculou-se o teor de portlandita com base na perda de massa entre $420^{\circ} \mathrm{C}-500^{\circ} \mathrm{C}$ e na perda de massa teórica desse mineral $(24,32 \%)$.

Tabela 59 - Faixas de temperatura para calcular as perdas de massa da análise termogravimétrica

\begin{tabular}{cc}
\hline $\begin{array}{c}\text { Faixa de } \\
\text { temperatura }\end{array}$ & Interpretação \\
\hline $20^{\circ} \mathrm{C}-100^{\circ} \mathrm{C}$ & perda de $\mathrm{H}_{2} \mathrm{O}$ livre \\
\hline $100^{\circ} \mathrm{C}-420^{\circ} \mathrm{C}$ & desidratação de componentes hidratados de cimento (silicatos, aluminatos e \\
& sulfatos de cálcio) \\
\hline $420^{\circ} \mathrm{C}-500^{\circ} \mathrm{C}$ & desidroxilação da portlandita $\left(\mathrm{Ca}(\mathrm{OH})_{2}\right)$ \\
\hline $500^{\circ} \mathrm{C}-700^{\circ} \mathrm{C}$ & descarbonatação da calcita $\left(\mathrm{CaCO}_{3}\right)$ \\
\hline
\end{tabular}


A Tabela 60 apresenta os resultados de perda de massa calculados com base nos termogramas obtidos. Os ensaios foram realizados nas barras de argamassa moldadas com o agregado milonito granítico, com os cimentos com e sem adições ativas, e submetidas ao ensaio acelerado a $80^{\circ} \mathrm{C}$ em solução $1 \mathrm{~N}$ durante 28 dias. Os teores de hidróxido de cálcio $\left(\mathrm{Ca}(\mathrm{OH})_{2}\right)$ foram calculados na base seca. A Figura 29 ilustra os resultados obtidos.

Tabela 60 - Perda de massa e teor de hidróxido de cálcio das barras de argamassa com agregado milonito granítico

\begin{tabular}{|c|c|c|c|c|c|c|c|}
\hline \multirow{2}{*}{ 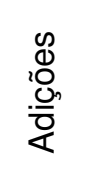 } & \multirow{2}{*}{$\begin{array}{l}\text { Tipos de } \\
\text { Cimento }\end{array}$} & \multirow{2}{*}{$\begin{array}{l}\text { Teor de } \\
\text { adição } \\
\text { (\% em } \\
\text { massa) }\end{array}$} & \multicolumn{4}{|c|}{ Perdas de massa (\%) } & \multirow{2}{*}{$\begin{array}{c}\text { Teor de } \\
\mathrm{Ca}(\mathrm{OH})_{2} \\
\text { (\% em massa } \\
\text { na base seca) }\end{array}$} \\
\hline & & & $\begin{array}{c}20 \mathrm{a} \\
100^{\circ} \mathrm{C}\end{array}$ & $\begin{array}{l}100 \mathrm{a} \\
420^{\circ} \mathrm{C}\end{array}$ & $\begin{array}{l}420 \mathrm{a} \\
500^{\circ} \mathrm{C}\end{array}$ & $\begin{array}{l}500 \text { a } \\
700^{\circ} \mathrm{C}\end{array}$ & \\
\hline ' & CP V-ARI & 0 & 5,03 & 3,17 & 0,83 & 1,43 & 3,59 \\
\hline \multirow{4}{*}{ 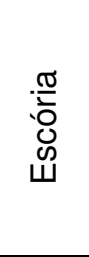 } & CP II-E & 15 & 4,85 & 3,61 & 0,67 & 1,44 & 2,90 \\
\hline & CP II-E & 30 & 5,56 & 3,47 & 0,53 & 0,80 & 2,31 \\
\hline & CP III & 45 & 4,67 & 4,08 & 0,37 & 1,03 & 1,60 \\
\hline & CP III & 60 & 5,07 & 4,33 & 0,23 & 0,43 & 1,00 \\
\hline \multirow{4}{*}{ 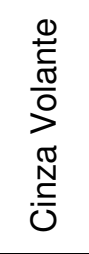 } & CP II-Z & 10 & 4,30 & 2,83 & 0,50 & 0,90 & 2,15 \\
\hline & CP II-Z & 15 & 5,67 & 3,13 & 0,47 & 1,00 & 2,05 \\
\hline & CP IV & 25 & 5,00 & 3,10 & 0,30 & 0,93 & 1,30 \\
\hline & CP IV & 35 & 5,33 & 2,80 & 0,17 & 0,80 & 0,74 \\
\hline \multirow{4}{*}{ 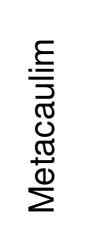 } & - & 5 & 4,00 & 3,10 & 0,47 & 1,14 & 2,01 \\
\hline & - & 10 & 4,42 & 3,85 & 0,33 & 1,33 & 1,60 \\
\hline & - & 15 & 5,18 & 4,01 & 0,27 & 1,20 & 1,17 \\
\hline & - & 20 & 3,65 & 4,00 & 0,50 & 0,83 & $0,00^{*}$ \\
\hline \multirow{3}{*}{ 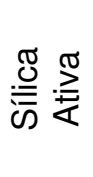 } & - & 5 & 5,30 & 4,00 & 0,66 & 1,99 & 2,86 \\
\hline & - & 10 & 6,15 & 3,49 & 0,43 & 2,16 & 1,88 \\
\hline & - & 15 & 4,00 & 2,65 & 0,17 & 0,33 & 0,72 \\
\hline
\end{tabular}

A análise termodiferencial não apresentou pico endotérmico a $450^{\circ} \mathrm{C}$ referente à disidroxilação da portlandita, embora a termodiferencial apresente perda de massa na faixa entre 420 e $500^{\circ} \mathrm{C}$ 
Teor de Álcalis das Barras de Argamassa com Agregado Milonito Granítico

A Tabela 61 apresenta os resultados de determinação dos teores de óxido de sódio $\left(\mathrm{Na}_{2} \mathrm{O}\right)$ e óxido de potássio $\left(\mathrm{K}_{2} \mathrm{O}\right)$ solúveis das barras de argamassa moldadas com o agregado milonito granítico, com os cimentos com e sem adições ativas, e submetidas ao ensaio acelerado a $80^{\circ} \mathrm{C}$ em solução $1 \mathrm{~N}$ durante 28 dias. A Figura 30 ilustra os resultados obtidos.

Tabela 61 - Teores de álcalis solúveis das barras de argamassa

\begin{tabular}{|c|c|c|c|c|c|}
\hline \multirow{3}{*}{ 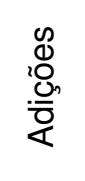 } & \multirow{3}{*}{$\begin{array}{l}\text { Tipos de } \\
\text { Cimento }\end{array}$} & \multirow{3}{*}{$\begin{array}{l}\text { Teor de adição } \\
\text { (\% em massa) }\end{array}$} & \multicolumn{3}{|c|}{ Teor (\% em massa) } \\
\hline & & & \multicolumn{3}{|c|}{ Milonito granítico } \\
\hline & & & $\mathrm{Na}_{2} \mathrm{O}$ & $\mathrm{K}_{2} \mathrm{O}$ & $\mathrm{Na}_{2} \mathrm{O}_{\mathrm{e}}$ \\
\hline ' & CP V-ARI & 0 & 0,90 & 0,03 & 0,92 \\
\hline \multirow{4}{*}{ 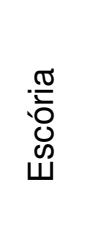 } & CP II-E & 15 & 0,92 & 0,04 & 0,95 \\
\hline & CP II-E & 30 & 0,88 & 0,03 & 0,90 \\
\hline & CP III & 45 & 0,80 & 0,05 & 0,83 \\
\hline & CP III & 60 & 0,75 & 0,05 & 0,78 \\
\hline \multirow{4}{*}{$\begin{array}{l}\stackrel{0}{ \pm} \\
\frac{\pi}{0} \\
\text { D } \\
\stackrel{\mathbb{N}}{N} \\
\stackrel{\frac{C}{U}}{0}\end{array}$} & CP II-Z & 10 & 0,88 & 0,04 & 0,91 \\
\hline & CP II-Z & 15 & 0,80 & 0,06 & 0,84 \\
\hline & CP IV & 25 & 0,72 & 0,07 & 0,64 \\
\hline & CP IV & 35 & 0,60 & 0,07 & 0,76 \\
\hline \multirow{4}{*}{ 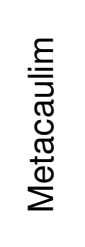 } & - & 5 & 1,07 & 0,07 & 1,12 \\
\hline & - & 10 & 0,95 & 0,05 & 0,98 \\
\hline & - & 15 & 0,92 & 0,11 & 0,99 \\
\hline & - & 20 & 0,85 & 0,10 & 0,92 \\
\hline \multirow{3}{*}{ 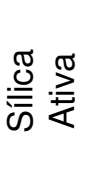 } & - & 5 & 1,02 & 0,10 & 1,09 \\
\hline & - & 10 & 0,85 & 0,15 & 0,95 \\
\hline & - & 15 & 0,75 & 0,18 & 0,87 \\
\hline
\end{tabular}




\section{$>$ Porosimetria}

Para a análise de distribuição do tamanho dos poros utilizou-se um porosímetro modelo AUTOPORE II-9215, fabricado pela Micromeritics Instruments Corporation, Estados Unidos.

Para a realização das análises porosimétricas, fragmentos representativos da barra de argamassa $n^{0} 1$, das combinações selecionadas, foram colocados em estufa a $105^{\circ} \mathrm{C}$ até obtenção de massa constante. Somente depois de resfriados à temperatura ambiente, as amostras foram colocadas no porta-amostra do porosímetro. A seguir, o conjunto foi submetido a condições de vácuo em baixa pressão para preencher o porta-amostra com mercúrio. A próxima etapa consistiu no aumento contínuo de pressão até atingir aproximadamente $414 \mathrm{MPa}$ (60.000 psi) para forçar a intrusão do mercúrio nos poros abertos. A capacidade teórica de intrusão alcança os poros de diâmetro superiores a $25 \AA$ (0,0025 $\mu \mathrm{m})$.

O princípio da metodologia consiste em medir o volume de intrusão de mercúrio por grama de amostra $(\mathrm{ml} / \mathrm{g})$, característico de cada pressão aplicada, possibilitando expressar esse volume em função do diâmetro dos poros. A Tabela 62 apresenta os principais resultados obtidos e a Figura 31 ilustra graficamente o volume de mercúrio intrudido em função do diâmetro dos poros.

Tabela 62 - Principais parâmetros obtidos no ensaio de porosimetria por intrusão de mercúrio para as barras de argamassa ensaiadas

\begin{tabular}{|c|c|c|c|c|c|c|c|c|c|c|}
\hline \multirow[b]{2}{*}{ Parâmetros } & \multicolumn{5}{|c|}{ Milonito granítico } & \multicolumn{5}{|c|}{ Basalto } \\
\hline & $\begin{array}{l}\frac{0}{20} \\
\frac{0}{0} \\
\frac{0}{0} \\
\frac{\varepsilon}{0} \\
\infty \\
\infty\end{array}$ & 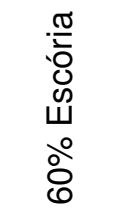 & 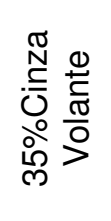 & 立 & 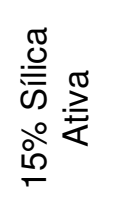 & 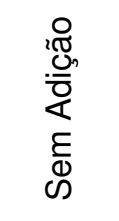 & 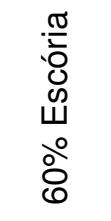 & 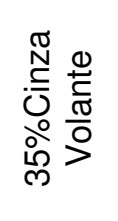 & 今̊ & 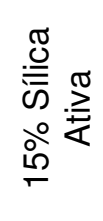 \\
\hline $\begin{array}{l}\text { Volume total de } \\
\text { intrusão }(\mathrm{ml} / \mathrm{g})\end{array}$ & 0,069 & 0,060 & 0,081 & 0,086 & 0,078 & 0,064 & 0,054 & 0,076 & 0,085 & 0,075 \\
\hline $\begin{array}{l}\text { Área total de } \\
\text { poros }\left(\mathrm{m}^{2} / \mathrm{g}\right)\end{array}$ & 23,11 & 23,34 & 29,93 & 24,93 & 31,00 & 16,15 & 25,80 & 25,19 & 34,71 & 29,07 \\
\hline $\begin{array}{l}\text { Diâmetro médio } \\
\text { de poros }(\mu \mathrm{m})\end{array}$ & 0,016 & 0,019 & 0,020 & 0,020 & 0,016 & 0,026 & 0,015 & 0,022 & 0,013 & 0,017 \\
\hline $\begin{array}{l}\text { Massa específica } \\
(\mathrm{g} / \mathrm{ml})\end{array}$ & 2,201 & 2,382 & 2,435 & 2,418 & 2,400 & 2,606 & 2,492 & 2,604 & 2,598 & 2,568 \\
\hline $\begin{array}{l}\text { M. específica } \\
\text { aparente }(\mathrm{g} / \mathrm{ml})\end{array}$ & 1,916 & 2,083 & 2,033 & 2,000 & 2,023 & 2,234 & 2,197 & 2,176 & 2,130 & 2,153 \\
\hline Porosidade (\%) & 13,1 & 12,6 & 16,5 & 17,3 & 15,7 & 14,31 & 11,9 & 16,4 & 18,0 & 16,2 \\
\hline
\end{tabular}

